\title{
FOREIGN HIGH-END RETAILERS IN CANADA, WHERE NEXT?
}

by

\author{
Nicole Serrafero \\ Bachelor of Science, Environmental Management and GIS \\ University of Toronto Mississauga, Mississauga, ON \\ Advanced Diploma, GIS for Business Concentration \\ Nova Scotia Community College COGS Campus, Lawrencetown, NS
}

\author{
A Major Research Paper \\ presented to Ryerson University \\ in partial fulfillment of the requirements for the degree of \\ Master of Spatial Analysis \\ in the program of Spatial Analysis
}

Toronto, Ontario, Canada, 2017

(C) Nicole Serrafero, 2017 


\section{Authors Declaration}

I hereby declare that I am the sole author of this MRP. This is a true copy of the MRP, including any required final revisions.

I authorize Ryerson University to lend this MRP to other institutions or individuals for the purpose of scholarly research.

I further authorize Ryerson University to reproduce this MRP by photocopying or by other means, in total or in part, at the request of other institutions or individuals for the purpose of scholarly research.

I understand that my MRP may be made electronically available to the public. 
Foreign high-end retailers in Canada, where next?

Master of Spatial Analysis, 2017

Nicole Serrafero, Spatial Analysis, Ryerson University

\begin{abstract}
Foreign high-end retailers have started to establish their brands in Canada. There are several locations across Canada that contain a significant number of them. Using these existing established high-end retail locations, this paper presents potential new locations for these high-end retailers to expand into. The paper deals with six of the major census metropolitan areas (CMA) in Canada: Toronto, Montreal, Vancouver, Calgary, Edmonton, and Ottawa. The demographic and household spending data at the census tract level were used to represent potential customers. Trade areas were created for each of the existing established high-end retail locations using 15-min and 20-min drive times. K-means cluster analysis was used to determine the results. Using a combination of the trade area demographics and the target cluster location, this paper has confirmed that there are potential locations, apart from existing clusters of high-end retailers, for foreign high-end retailers to expand into.
\end{abstract}




\section{Acknowledgements}

I would like to acknowledge my supervisor Professor Stephen Swales for his continued support, guidance and patience throughout the entire writing of this paper. I would also like to acknowledge my second reader Professor Wayne Forsythe for his support and helpful suggestions.

I would also like to acknowledge Tony Lea and Philip Tananka from Environics Analytics for providing me permission to use the DemoStats 2016 and HouseholdSpend 2016 datasets.

Finally, I would like to thank my family for their support and motivation throughout my graduate studies. 


\section{Table of Contents}

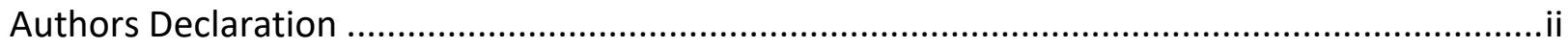

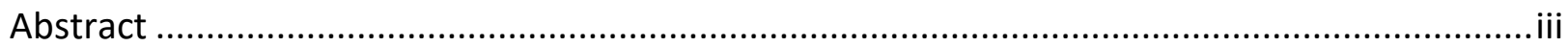

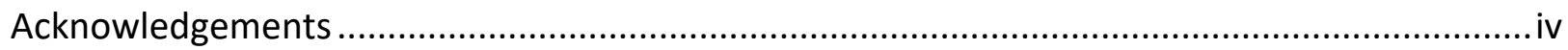

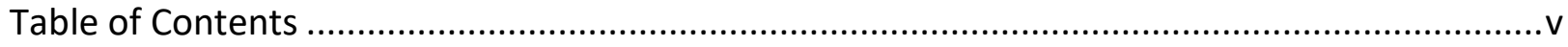

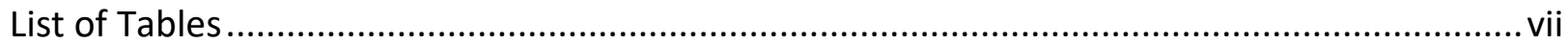

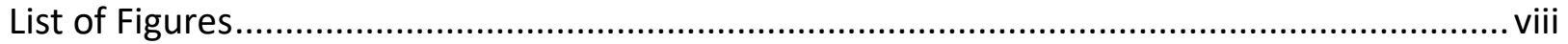

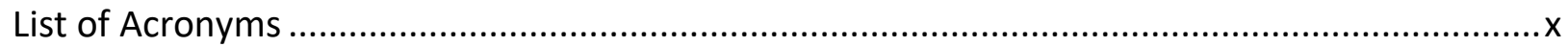

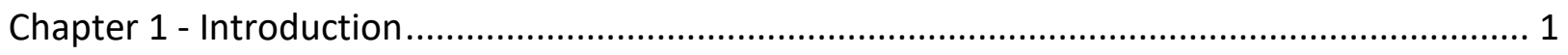

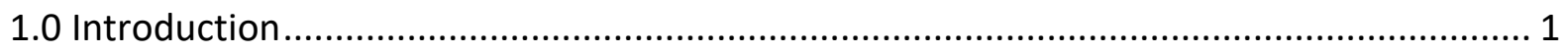

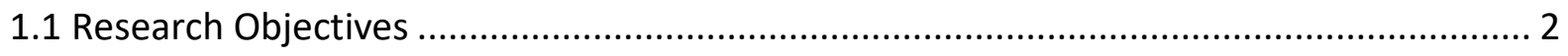

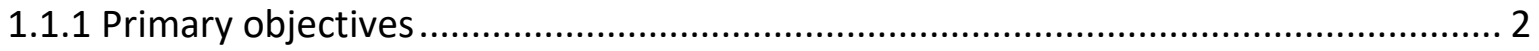

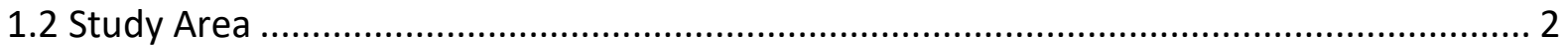

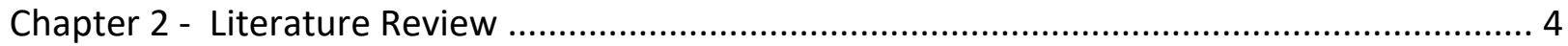

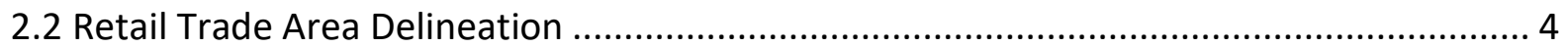

2.3 Demographics and Retail Patronage ..................................................................... 9

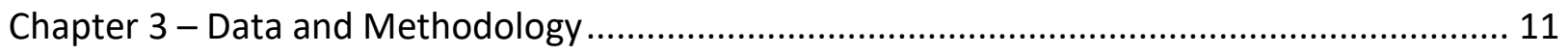

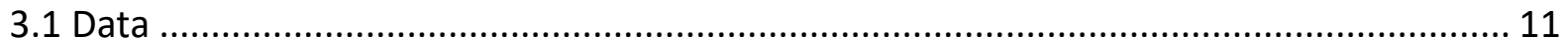

3.1.1 Foreign High-End Retailer Locations .............................................................. 11

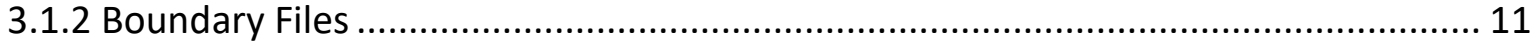

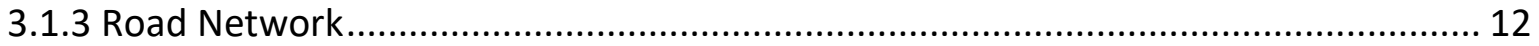

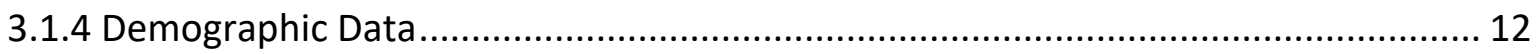

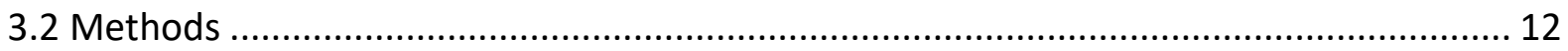

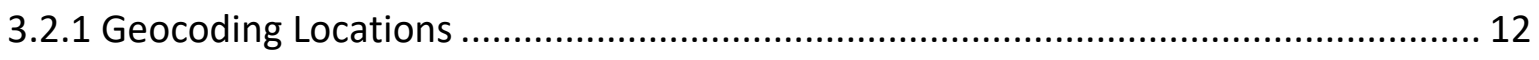

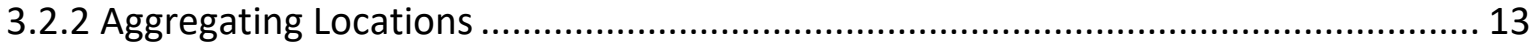

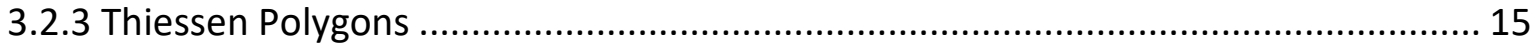

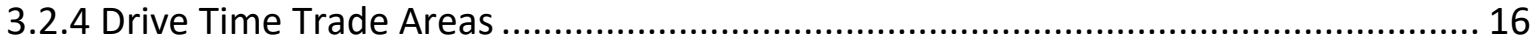

3.2.5 Demographic Data Preparation......................................................................... 27

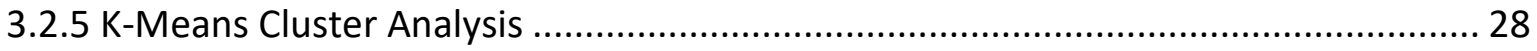

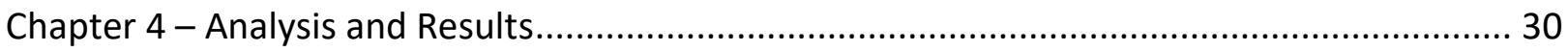

4.1 Trade Area Demographics and Household Spending Habits ...................................... 30

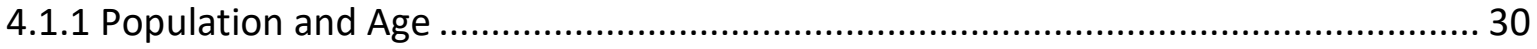

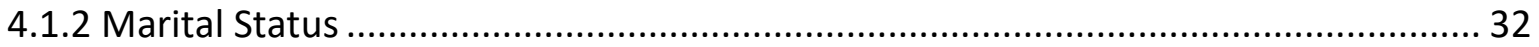




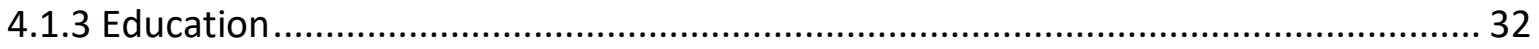

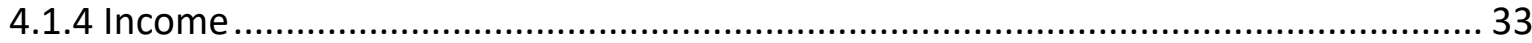

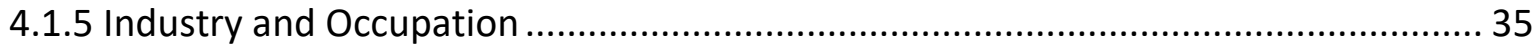

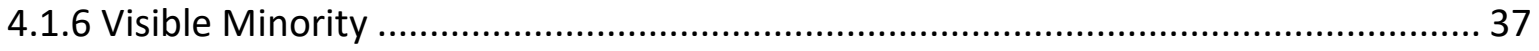

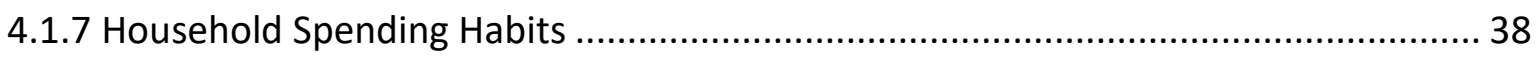

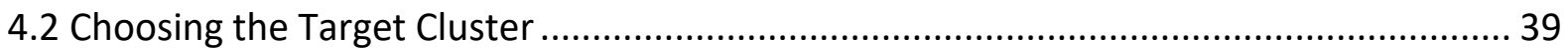

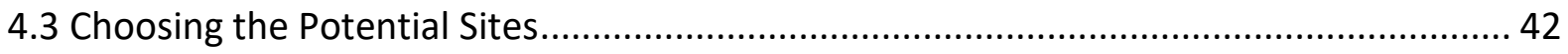

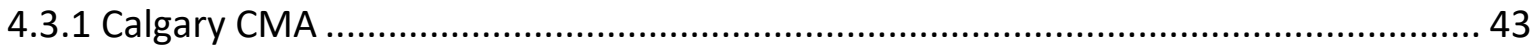

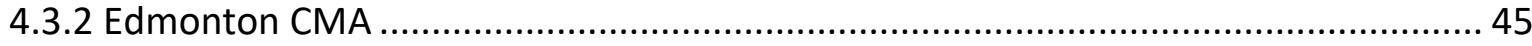

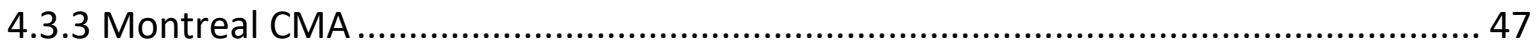

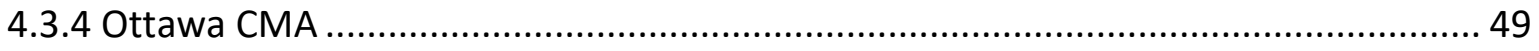

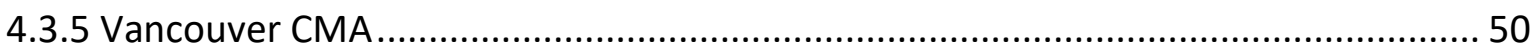

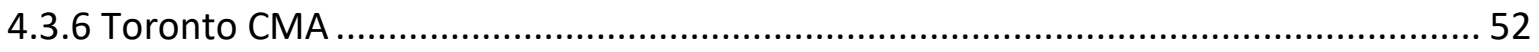

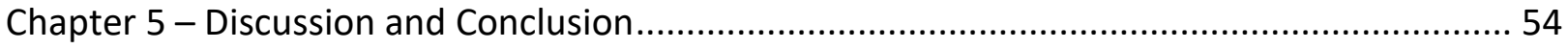

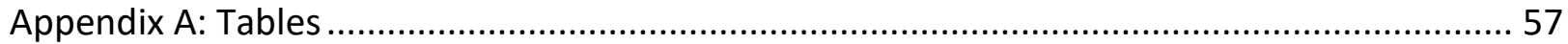

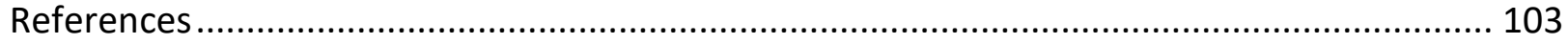




\section{List of Tables}

Table 3.1: Top high-end retail locations and retailers in them.......................................... 14

Table 4.1: Final cluster centres for all variables - part 1. ..................................................... 40

Table 4.2: Final cluster centres for all variables - part 2. ............................................... 41

Table A1: Foreign high-end retailers store location information. ........................................ 57

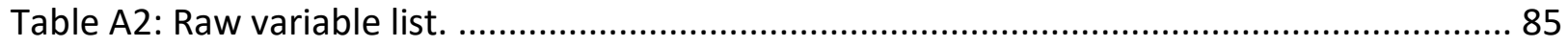

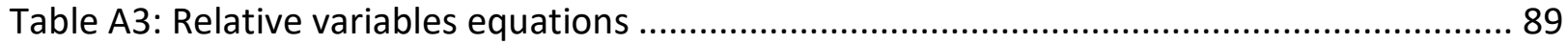

Table A4: Relative trade area data for female age variables. ............................................. 92

Table A5: Relative trade area data for male age variables. ................................................ 93

Table A6: Relative trade area data for marital values..................................................... 94

Table A7: Relative trade area data for education variables................................................. 95

Table A8: Relative trade area data for income variables.................................................... 96

Table A9: Average household income values for all trade areas. .......................................... 97

Table A10: Relative trade area data for industry variables - part 1................................... 98

Table A11: Relative trade area data for industry variables - part 2 .................................... 99

Table A12: Relative trade area data for occupation variables ........................................... 100

Table A13: Relative trade area data for visible minority variables. ..................................... 101

Table A14: Relative trade area data for household spending variables. ............................. 102 


\section{List of Figures}

Figure 1.1: Foreign high-end retailers in Canada.......................................................... 3

Figure 3.1: Thiessen polygons for Toronto CMA ................................................................. 16

Figure 3.2: Drive time trade area for Chinook Centre, Calgary........................................... 17

Figure 3.3: Drive time trade area for Rideau Centre, Ottawa............................................... 18

Figure 3.4: Drive time trade area for downtown Vancouver............................................. 18

Figure 3.5: Drive time trade area for Sherway Gardens, Toronto. ........................................ 19

Figure 3.6: Drive time trade area for Square One, Mississauga. .......................................... 19

Figure 3.7: Drive time trade area for Yorkville, Toronto........................................................ 20

Figure 3.8: Drive time trade area for Toronto Eaton Centre, Toronto .................................... 20

Figure 3.9: Drive time trade area for Yorkdale Shopping Centre, Toronto.............................. 21

Figure 3.10: Drive time trade for Toronto Premium Outlets, Halton Hills.............................. 21

Figure 3.11: Census tracts in the drive time trade areas for Chinook Centre, Calgary.............. 22

Figure 3.12: Census tracts in the drive time trade areas for downtown Vancouver................ 23

Figure 3.13: Census tracts in the drive time trade areas for Rideau Centre, Ottawa................ 23

Figure 3.14: Census tracts in the drive time trade areas for Square One, Mississauga. ........... 24

Figure 3.15: Census tracts in the drive time trade areas for Sherway Gardens, Etobicoke. ...... 24

Figure 3.16: Census tracts in the drive time trade areas for Toronto Eaton Centre, Toronto. .. 25

Figure 3.17: Census tracts in the drive time trade areas for Toronto Premium Outlets, Halton

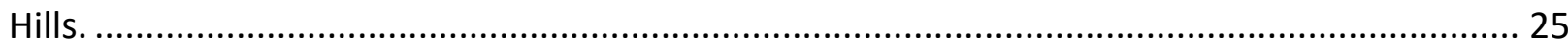

Figure 3.18: Census tracts in the drive time trade areas for Yorkdale Shopping Centre,

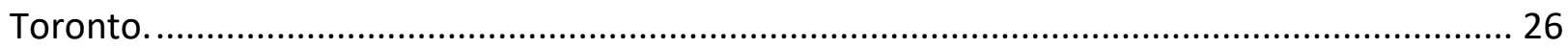

Figure 3.19: Drive time trade for Yorkdale Shopping Centre, Toronto................................... 26

Figure 3.19: Census tracts in the drive time trade areas for Yorkville, Toronto...................... 26

Figure 4.1: Female and male age distribution at the aggregate trade area level..................... 31

Figure 4.2: Female and male age distribution at the aggregate CMA level............................ 31

Figure 4.3: Marital status distribution at the aggregate trade area and CMA level................. 32

Figure 4.4: Education level distribution at the aggregate trade area and CMA level................ 33

Figure 4.5: Income level distribution at the aggregate trade area and CMA level................... 34

Figure 4.6: Average household income for each of the drive time trade areas ...................... 34

Figure 4.8: Occupation distribution at the aggregate trade area and CMA level..................... 36

Figure 4.7: Industry distribution at the aggregate trade area and CMA level........................ 36 
Figure 4.9: Visible minority verses non-visible minority at the aggregate trade area and CMA level.

Figure 4.10: Visible minority distribution at the aggregate trade area and CMA level............ 38

Figure 4.11: Household spending distribution at the aggregate trade area and CMA level. ..... 39

Figure 4.12: Target cluster in the Calgary CMA............................................................... 44

Figure 4.13: Average household income levels in the Calgary CMA....................................45

Figure 4.15: Average household income levels in the Edmonton CMA................................ 46

Figure 4.14: Target cluster in the Edmonton CMA......................................................... 46

Figure 4.17: Average household income levels in Montreal CMA ....................................... 48

Figure 4.16: Target cluster in the Montreal CMA. ............................................................. 48

Figure 4.18: Target cluster in the Ottawa CMA.................................................................... 49

Figure 4.19: Average household income levels in the Ottawa CMA.................................... 50

Figure 4.20: Target cluster in the Vancouver CMA. .............................................................. 51

Figure 4.21: Average household income levels in Vancouver CMA..................................... 51

Figure 4.23: Average household income values for the Toronto CMA................................. 53

Figure 4.22: Target cluster in the Toronto CMA. ............................................................ 53

Figure 4.21: Target cluster in the Toronto CMA. ............................................................. 53 


\section{List of Acronyms}

$\mathrm{CMA}=$ Census Metropolitan Area 


\section{Chapter 1 - Introduction}

\subsection{Introduction}

In the past few years, there has been an influx of foreign high-end retailers establishing their brands in Canada. These high-end retailers tend to cluster their stores close to one another, usually on the same street or in the same retail type. Shopping centres such as the Square One Shopping Centre in Mississauga, Yorkdale Mall in Toronto, and Sherway Gardens in Toronto, are creating "Luxury Wings" just for these high-end retailers (Retail Insider, 2016). Streets such as Bloor St. West (Yorkville) in Toronto, Sherbrooke Street West in Montreal, and Alberni/Burrard Street in Vancouver are hotspots for high-end retailers (Retail Insider, 2016). Not only do these locations attract local customers, but they are major tourist attractions. This exclusivity of locations drives the desire to purchase as several of these chains only have a small number of stores worldwide.

As the name implies, high-end retailers sell products that require a certain level of income to purchase. Those who are in the higher income bracket are likely the main demographic that would shop regularly at one of these high-end retailers. Canada has seen an increase of $2.4 \%$ of employment income since 2012 (Statisitics Canada, 2017). More and more people will be able to afford these high-end luxury goods and will likely want to buy them. There are only a few Canadian high-end retailers, the majority of these foreign brands historically and recently have come from the United States (Emmons \& Hernandez, 2016). There has been a recent trend of European and Asian coming into the market especially at the high-end. As more and more of these retailers establish stores in Canada, the need to travel outside the country to shop at these high-end retailers has diminished. The current location trend of these foreign brands is mainly shopping centres. These account for approximately $45 \%$ of the foreign retailers as opposed to street-front or free-standing stores (Emmons \& Hernandez, 2016). Ontario contains the highest number of foreign owned stores, accounting for $45 \%$ of the total foreign owned stores, with the Toronto CMA having the highest amongst the CMAs (Emmons \& Hernandez, 2016). To benefit from the current income trend in Canada, high-end retailers will need to strategically place their stores in major markets to attract these key customers. 


\subsection{Research Objectives}

The purpose of this paper is to review the current spatial distribution of foreign high-end retailers in Canada and evaluate where these retailers can expand next using existing clusters of said retailers and high-end market composition.

\subsubsection{Primary objectives}

- Ascertain the spatial distribution of foreign high-end retailers across Canada.

- Determine retail locations and areas that have high clusters of foreign high-end retailers.

- Create trade areas to represent the customer's patronage of major high-end retail locations

- Determine other areas that match the demographic profile of the main clusters of foreign high-end retailers

\subsection{Study Area}

The study area encompasses six of the major metropolitan areas in Canada: Toronto, Montreal, Vancouver, Calgary, Edmonton, and Ottawa. These locations have almost all of the current foreign high-end retailers. The extents of each of the cities will be their CMA boundaries. Figure 1.1 displays the retail locations in Canada, majority of them are located within one of the six CMA selected for the study. 


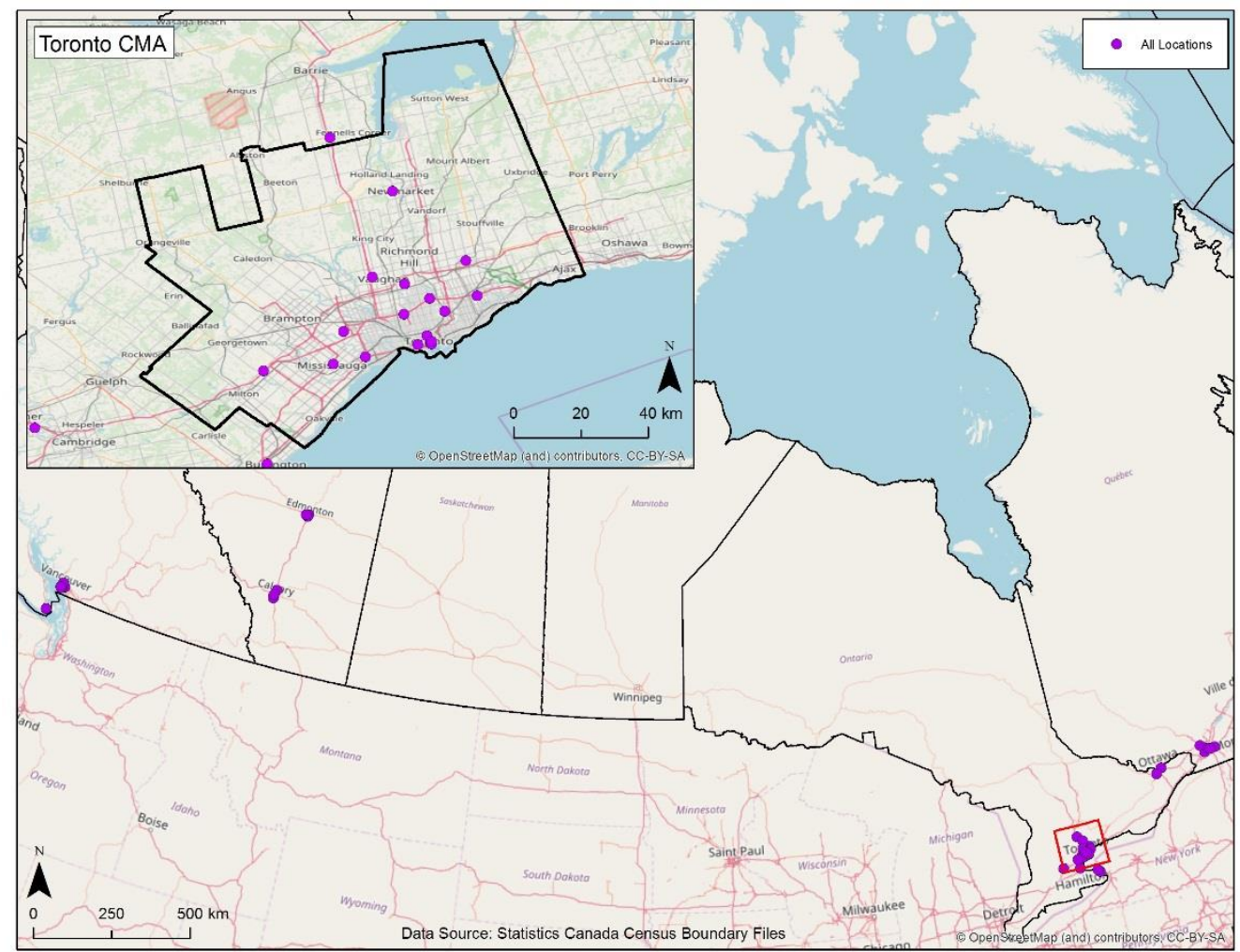

Figure 1.1: Foreign high-end retailers in Canada. 


\section{Chapter 2 - Literature Review}

\subsection{Retail Trade Area Delineation}

In retail analysis, there are two main approaches to model the trade area of a retail location or a set of retail locations: deterministic and probabilistic approaches (Bermingham, Hernandez, Lea, \& 2004). The deterministic approach assumes that the customers will only patronize one store. If a customer falls within that given store's trade area they will be assigned to that location and that location only. Examples of deterministic approaches include: circular trade areas, convex hulls, drive time/distance trade areas, Thiessen polygons, and the Converse break-point method. The probabilistic approach partially assigns customers to several stores. The core principle of the probabilistic approach is that the closer you are to the store, the more likely you will visit that store. Locations closer to the customer will be given a higher probability score. Examples of probabilistic approaches include weighted percent demographics, statistically modeled approaches, and the Huff Model (which considers both distance and size of centres).

One of the simplest and basic trade area delineation techniques is the Thiessen's polygon method. This method uses Euclidean distance to create trade areas based on a set of store locations assuming customers will go to the nearest store. Anything that falls in a stores trade area is closer to that store than any other store location (Bermingham et al., 2004). There is no overlap between the polygons as it is a deterministic approach. If a location is on the border of two polygons, both locations have equal influence on it. This method is widely used in chain and complex retail markets to try to find "gaps" within said market and is particularly useful in early stages of chain expansion (Bermingham et al., 2004). The main concern with this method is it is a one-dimensional view on the retail environment; it only uses distance to determine its trade areas. In most cases, the Thiessen Polygon method is used to gain general insight on the state of the retail market within the study area. High-end retailers tend to want to be exclusive in where they place their stores, therefore only a few (or one) locations are placed per city. This results in only a few cities that have more than one large cluster of high end retailers. In Canada, the Toronto CMA is the only one with a significant number of clusters of high-end 
retailers. There are other CMA's that have clusters of high end retailers but only one or two. To use the Thiessen's polygon method in a meaningful way, more locations are required.

The Converse break-point method is a gravity model; a gravity model assumes that there are factors that pull customers towards a certain location. Every location has a pull factor but some locations have stronger pulls than others (Reilly, 1931). The key factor in gravity models is distance and the size of the two locations. To pull customers farther distances, there are factors that increase the "attractiveness" of the location. Customers are willing to travel farther distances if the attractiveness is great enough. The Converse break-point method defines that the size of the two locations determines the attractiveness. The larger the size of one location, the larger its trade area will be (Reilly, 1931). The Converse break-point method was used by Bozdo, Thanasi, and Vjollca (2013) to define the catchment area of shopping centres located in Albania. Three shopping centres were looked at, Citypark, Tirana East Gate (TEG) and Qendra Tredtare Univers (QTU) which are in the cities Durres, Tirana, and Elbasan respectively. The population size of the cities was used as the size (attractiveness) variable for the study. The breakpoint between Tirana and Durres was calculated first, followed by the breakpoint between Tirana and Elbasan. Tirana is the most influential city, it has the largest population and catchment area out of all three of the cities. The three shopping centres in the study are located close to the City of Tirania, meaning that all of them are competing for very similar potential customers. Two of the shopping centres, QTU and TEG, are owned by the same development company and have overlapping trade areas. The researchers concluded that different marketing and tenant mix should be implemented between these two shopping centres to reduce cannibalisation and increase attractiveness for the customers.

The market penetration method was created by William Applebaum in the 1960's and can be used to model a trade area based on customer location (Bermingham et al., 2004). This method requires two sets of data to be used: a list of customers and the number of households which represent potential customers within a given area. It is often used on a single location that wishes to increase its sales by extending its trade area in space or by attracting a greater proportion of households within the existing trade area (Jones \& Simmons, 1993). Retail chains that have multiple locations and have customer data for each of the locations would benefit the 
most from this technique. In Applebaum's original method a grid of squares was created over the study area, in modern studies small geographic units like dissemination areas and census tracts are used. To calculate market penetration the number of customers within each area is divided by the total population or household within that area. The primary trade area is created that includes $60 \%$ of the customers and the secondary trade includes the next $25 \%$ of customers. The areas that are included in the primary and secondary trade areas is determined by starting with the area that has the highest percentage of customers then moving on to the next highest area (Bermingham et al., 2004). The resulting trade areas are unlike traditional ones as they tend to have gaps or holes within them. If the grid method is used, it hard to determine what the ideal grid size is and how to divide up the population within the squares. Using small geographic areas fix these two issues but the different sizes of these geographies cause other concerns. In cities, these geographic units are small but in more rural areas they can be very large. Bermingham et al. (2004) used an extended Applebaum technique that incorporates the small geographic areas, market penetration, and the distance from the customer to the location. Instead of using the market penetration as the method to select the areas for the trade area, a score is created so that areas with small distances and high penetration are at the top of the list. This list is then used to create the primary and secondary trade areas in conjunction with a set of rules to ensure that there are no gaps or outliers. The rules themselves are subjective but subjectivity is reduced compared to Applebaum's original method. In the case of high-end retailers, customer data would be hard to obtain for each individual retailer. Instead, customer data can be obtained for the retail location they fall into, such as a shopping centre. As most of the high-end retailers in Canada are located within shopping centres obtaining customer data on these locations would allow for the Applebaum technique to be used. The issue is that there are still a significant number of retail locations that do not fall within a shopping centre and have a significant cluster of foreign-high end retailers. To ensure that the trade areas created represent potential customers better, a technique that encompasses both types of locations would be preferred. 
The Huff model asks the question: what is the probability that the consumers in an area will shop at one of a number of centres based on the relative utility of all the centres (Swales, 2008). It has become one of the more popular models to use in retail analysis due to its versatility to tackle both simple and complex problems (Dramowicz, 2005). The Huff model is a probabilistic trade area approach therefore, each customer (or area) is assigned a percentage probability that they will patronize a store. In its most basic form, the Huff model determines the probability ( $\mathrm{Pij}$ ) that an individual (i) will shop at a store (j) based on the attractiveness (Aj) of that store and the distance (Dij) that the individual is away from that store (Huff, 2003). This relationship is calculated based on the following formula:

$$
P_{i j}=\frac{A_{j}^{\alpha} D_{i j}^{-\beta}}{\sum_{j=1}^{n} A_{j}^{\alpha} D_{i j}^{-\beta}}
$$

The basic Huff model states that the store size is used for the attractiveness value $(A j)$, however this is a simplistic measure of attractiveness. Many researchers have adopted more complex methods of representing attractiveness by modifying the basic Huff Model formula to fit their needs or calibrate the model with other data. De Beule, Van den Poel, and Van de Weghe (2014), used an extended Huff model to model the Belgian grocery market. To calibrate the model, several data inputs that were all publicly available were used. These inputs include store size, brand attention, language borders, grocery store concepts, and distance. The model was even validated on multiple geographic levels: block, store and brand level. The resulting model was found to be robust and could be used for other businesses. The Huff model is similar to the Applebaum method as it assigns a percentage to each of the geographic areas, however they are fundamentally different. The Applebaum method uses actual customer locations to show what the penetration is whereas the Huff model is a predictive and theoretical model. The Huff model is better suited for modeling trade areas for multiple locations as it only requires the distance and an attractiveness value. As many of the foreign high-end retailers can be found in multiple locations and actual customer data are not available for use in this paper, 
the Huff model would be a more suitable method to be used to model the trade areas of these locations.

People within cities mostly rely on the car to get to and from their destination efficiently and quickly. In the Toronto CMA, 69.9\% of commuters get to work by car (Statistics Canada, 2011a). The remaining $30.1 \%$ use public transit, walk or bike to work. Within the core of the city, owning a car is less important as there are several options to choose from that are a walking distance or a few transit stops away. Within the suburbs, this becomes less true. A car is an essential part of daily life not only for commuters but for those who want to go shopping. To represent these people, drive time/distance trade areas have been used. These trade areas are one of the simpler trade area delineation techniques as they only require locations and a road network to build. In its most basic form, travel distance can be used with any road network. To represent real-life situations, travel times are used more readily. Travel times can be created using a basic road network and can be optimized when data on actual drive times are put into the model.

As the majority of the foreign high-end retailers are within shopping centres, the travel time that people are willing to go to shop at these retailers is important to investigate. An extensive study by Brunner and Mason (1968) concluded that a 15-min drive time will encompass $75 \%$ of the customers. For the study, five shopping centres located in Toledo, Ohio were looked at. These shopping centres ranged from downtown shopping centres to suburban more traditional shopping centres. Initially, the cumulative percentage and percentage of customers within five min intervals of drive time for each mall were calculated. At the $11-15$ min mark for all of the malls, the majority of the customers had been captured. At the 20-min mark over $80 \%$ of the customers had been captured. To ensure that the majority of customers are captured, a 15 - 20 min drive time trade area would work. Cui (2012) used the 15-min drive time to develop a trade area delineation technique for retail chains. They used a combination of the 15-min drive time and generalized network Voronoi diagrams conceptualized by Okabe et al. (2008). The road network was modeled so that traffic conditions, turn restrictions, and road restrictions (like one-way streets) could be represented. With regards to high-end retailers, a 15-min drive time would suffice for the primary trade areas as it will likely capture the majority 
of customers. The 20-min drive time could also be used as the primary trade or secondary trade area as customers would be more willing to drive a bit longer to at a high-end retailer as they are a specialized retail market (Jones \& Simmons, 1993).

\subsection{Demographics and Retail Patronage}

The second objective of this project is to identify the key demographics associated with each of the high-end shopping centres through customer profiling. Customer profiling is the process of determining the demographic characteristics of the customers who patronize any given location (Jones \& Simmons, 1993). In most cases customer profiling is done using actual customer data that are collected by the retailer themselves however, it can still be done using demographic data alone such as census data. There are several key demographics that researchers have identified as influencing store patronage (Mishra, Sridhar \& Jain , 2015; Carpenter, 2006; Marjanen, Engblom \& Malmari, 2013). These demographic variables include age, gender, marital status, education, and income. Depending on the study area and location, ethnicity can play a major role in customer profiling (Carpenter, 2006). Ethnicity is an important factor when looking at Canadian customers. Based on the last census findings, $20.6 \%$ of the total population of Canada is foreign-born, which is the highest proportion amongst the G8 countries (Statistics Canada, 2011b). Considering what previous research has determined to be key demographics will help narrow down what should be used when profiling the customers in this study.

Demographics alone only provide one side of the customers. To understand the whole picture, researchers have employed other data to get a better understanding of who their customers are. These data include shopping behaviours, attitudes, values, and lifestyles of the customers themselves (Kuruvilla \& Joshi, 2010). Segmentation systems allow researchers to obtain all these additional data without the need to collect or create them separately. A segmentation system takes a set of people and puts them into groups based on their

characteristics. There are several types of segmentation systems that involve different types of data, however the most useful are those based on geodemographics. Geodemographics relies on two key principles, firstly, people who live in the same area or neighbourhood tend to have 
similar characteristics as compared to those who live further away. Secondly, these areas can be grouped together and areas that share similar characteristics but are geographically far apart can be put into the same group (Leventhal, 2016). These segmentation systems at their core rely on census data and are supplemented by other types of data such as surveys, questionnaires, and transaction history. Looking at the groups within the segmentation system makes it easier to link one place to another when compared to looking at demographics alone. 


\section{Chapter 3 - Data and Methodology}

\subsection{Data}

\subsubsection{Foreign High-End Retailer Locations}

The initial list of foreign high-end retailers was created based on the retailers found within the "Luxury Wings" (Retail Insider, 2016) of shopping centres. These shopping centres include Square One Shopping Centre, Yorkdale Mall, Sherway Gardens (all in the Toronto CMA), Oakridge Centre (Vancouver), Chinook Centre (Calgary) and the West Edmonton Mall (Edmonton). The affluent streets; Bloor St. West (Toronto), Sherbrooke Street West (Montreal), and Alberni/Burrard Street (Vancouver), were also looked at to compile the initial list. Additional locations and retailers were added to the list by looking at what other foreign high-end retailers were found in the same location or in the same area. Several details about each retailer and their location(s) were recorded in a table. The complete list of data that were recorded can be seen in Appendix A, Table A1. In total, 47 individual brands were found, in a total of 259 stores. The retail type was recorded so the locations could be divided into one of six groups based on their location. The six retail types are: airports, ancillary locations, major downtown malls, outlet malls, strip malls, and traditional shopping centres. For those located on a street, an "area name" was given to them. These area names were added in the "Retail Location" field so that stretches of a street, or a collection of streets, could be aggregated into one location to represent all of them. Figure 1.1 displays all the geocoded foreign high-end retail locations in Canada.

\subsubsection{Boundary Files}

The census tract and Census Metropolitan Area (CMA) cartographic boundary files for all of Canada were downloaded from the Statistics Canada website from the 2011 dataset (Statistics Canada, 2011c). The 2011 dataset was used as the demographic data are built on 2011 data. A CMA is named after the core city and includes its surrounding municipalities that have a high degree of integration through commuting with the core city (Statistics Canada, 2011d). The census tract level will be used for the analysis as it is a small and stable geographic area. The census tracts are created by subdividing the CMA and Census Agglomerations (CA) 
(Statistcs Canada, 2011e). For the purposes of this study, only the six major CMAs will be looked at: Toronto, Montreal, Vancouver, Calgary, Edmonton, and Ottawa.

\subsubsection{Road Network}

The road network dataset for all of Canada was taken from the 2015 CanMap@ content suite from DMTI Spatial (DMTI Spatial Inc., 2015). The file contains all files necessary to perform network analysis within ArcMap (Version 10.0). The network has already been built and configured to include all road restrictions and drive time. The drive time is based on a combination of the length, elevation, and the speed limit of the road.

\subsubsection{Demographic Data}

The demographic data were obtained from the 2016 DemoStats dataset and the 2016 HouseholdSpend dataset from Environics Analytics (2016). The data were compiled by Environics Analytics and were provided as a .DBF file at the census tract level. In total, 137 variables were obtained for seven themes of data. Each theme contains the variables that pertain to it, the themes are as follows: Population, Marital Status, Income, Occupation, Visible Minority status, Education, and Household Spending habits. The complete list of variables with their name and description can be found in Appendix A, Table A2.

\subsection{Methods}

\subsubsection{Geocoding Locations}

Most of the retail locations have a single coordinate associated with them, like those located in shopping centres or airports. Other retailers are located along a street, resulting in multiple coordinates. The locations were geocoded using the "EnhancedPostalPoint" 2015 file by DMTI Spatial Inc from their 2015 CanMap ( content suite. which contains the coordinates of the postal codes for all of Canada. In Alteryx (Version 11.0) software, the "EnhancedPostalPoint" table was joined to the store locations table on the postal code field. All records in the location table were successfully joined to the "EnhancedPostalPoint" table. Once all the records had their respective coordinates, they were converted into map points using the "Create Points" tool in Alteryx (Version 11.0). The tool uses latitude and longitude coordinates 
to create a spatial object that represents that point. In Alteryx (Version 11.0), spatial data have a field type called "spatial object" that holds the spatial data in their own field. If it is a point it will be a point, the same goes for line and polygon data. The spatial object field is used in Alteryx (Version 11.0) for any spatial process. The output from the tool was exported as a shapefile to be used in ArcMap (Version 10.0) software. Each point was checked in ArcMap (Version 10.0) using the Streets Basemap. As mentioned before, the retailers located on a street were given an area name to group them together. A new set of coordinates needed to be given to these locations to have one coordinate per retail location. The coordinates given to these locations were based on a central point along the street or collection of streets. For example, Yorkville contains all high-end retail locations that are within the bounding streets of Bloor Street, Davenport Road, Yonge Street, and Avenue Road including Yorkville village. The centre point was determined by using the "Mean Center" tool in ArcMap (Version 10.0). The resulting centre point coordinates replaced the existing coordinates from the earlier geocoding result. Figure 1.1 displays all the geocoded foreign high-end retail location in Canada.

\subsubsection{Aggregating Locations}

The resulting shapefile from the geocoding step was brought into Alteryx (Version 11.0). A field called "Count" was added to the file that just contained the number 1 . The "Summarize" tool was used on the data by grouping on the retail type, summing by the newly created count field, and taking the first record found in the spatial object field. The resulting output was a list of retail types, the number of retailers associated with them, and a point associated with that location. Since each retail location has only one coordinate associated with it, the first record in the Summarize tool will produce the correct point for that retail type. The resulting table was exported as a point shapefile to be used in later steps. The new points were checked again in ArcMap (Version 10.0) using the "Streets" basemap as a reference. The shapefile was ordered in descending order on the summed count field to determine where the high clusters of foreign high-end retailers exist. Locations that contained more than 10 high-end retailers in them were chosen from the result: Yorkdale Shopping Centre, Yorkville, Sherway Gardens, Toronto Eaton Centre, downtown Vancouver, Chinook Centre, Toronto Premium Outlet, Square One, and the Rideau Centre. These locations were exported as a separate shapefile called "Top retail 
locations", Table 3.1 contains the attributes of that shapefile showing the name of the location, count of foreign high-end retailers, list of foreign high-end retailers, and type of retail location.

Table 3.1: Top high-end retail locations and retailers in them.

\begin{tabular}{|c|c|c|c|}
\hline Retail Location & Count & List of Retailers & Retail Type \\
\hline $\begin{array}{l}\text { Yorkdale } \\
\text { Shopping } \\
\text { Centre }\end{array}$ & 28 & $\begin{array}{l}\text { All Saints,Ann Taylor,Bulgari,Burberry,COS,Coach,DAVID } \\
\text { YURMAN,Hugo Boss Outlet,Jaeger Lecoultre,Jimmy Choo,John } \\
\text { Varvatos,Kate Spade,Lacoste,Louis Vuitton,Massimo } \\
\text { Dutti,Michael Kors,Moncler } \\
\text {,Mulberry,Nordstrom,Reiss,Salvatore Ferragamo,Stuart } \\
\text { Weitzman,Ted Baker,Tiffany and Co.,Tory } \\
\text { Burch,Tumi,Versace,Vince Camuto }\end{array}$ & $\begin{array}{l}\text { Traditional } \\
\text { Shopping Centre }\end{array}$ \\
\hline $\begin{array}{l}\text { Downtown } \\
\text { Vancouver }\end{array}$ & 26 & $\begin{array}{l}\text { All Saints,Brunello Cucinelli,Burberry,Coach,Ermenegildo } \\
\text { Zegna,Escada,George Rech,Gucci,Hermès,Hugo Boss,Jaeger } \\
\text { Lecoultre,Kate Spade,Louis Vuitton,Massimo Dutti,Michael } \\
\text { Kors,Nordstrom,Salvatore Ferragamo,Stuart Weitzman,Ted } \\
\text { Baker,Tiffany and Co.,Tory Burch,Tumi,Versace }\end{array}$ & $\begin{array}{l}\text { Retail strip } \\
\text { /Major } \\
\text { Downtown Mall }\end{array}$ \\
\hline $\begin{array}{l}\text { Sherway } \\
\text { Gardens }\end{array}$ & 16 & $\begin{array}{l}\text { Ann Taylor,Coach,Eileen Fisher,Hugo Boss Outlet,Kate } \\
\text { Spade,Lacoste,Michael Kors,Nordstrom,Reiss,Saks Fifth } \\
\text { Avenue,Saks Fifth Avenue OFF 5TH,Stuart Weitzman,Ted } \\
\text { Baker,Tiffany and Co.,Tory Burch,Tumi,Vince Camuto }\end{array}$ & $\begin{array}{l}\text { Traditional } \\
\text { Shopping Centre }\end{array}$ \\
\hline $\begin{array}{l}\text { Toronto Eaton } \\
\text { Centre }\end{array}$ & 16 & $\begin{array}{l}\text { All Saints,Ann Taylor,Coach,Hugo Boss Outlet,Kate } \\
\text { Spade,Lacoste,Massimo Dutti,Michael } \\
\text { Kors,Nordstrom,Reiss,Saks Fifth Avenue,Scotch and Soda,Stuart } \\
\text { Weitzman,Ted Baker,Tumi,Vince Camuto }\end{array}$ & $\begin{array}{l}\text { Major } \\
\text { Downtown Mall }\end{array}$ \\
\hline Yorkville & 16 & $\begin{array}{l}\text { Burberry,COS,Coach,Dolce \& Gabbana,Escada,George } \\
\text { Rech,Gucci,Hermès,Hugo Boss Outlet,Kate Spade,Louis } \\
\text { Vuitton,Michael Kors,Mulberry,Prada,Stuart Weitzman,Tiffany } \\
\text { and Co. }\end{array}$ & Retail Strip \\
\hline Chinook Centre & 13 & $\begin{array}{l}\text { Burberry,Coach,Eileen Fisher,Hugo Boss Outlet, Kate } \\
\text { Spade,Lacoste,Michael Kors,Nordstrom,Stuart Weitzman,Ted } \\
\text { Baker,Tiffany and Co.,Tory Burch,Tumi }\end{array}$ & $\begin{array}{l}\text { Traditional } \\
\text { Shopping Centre }\end{array}$ \\
\hline $\begin{array}{l}\text { Toronto } \\
\text { Premium Outlet }\end{array}$ & 13 & $\begin{array}{l}\text { Armani ,Burberry,Coach,Hugo Boss Outlet,Jimmy Choo,Kate } \\
\text { Spade,Michael Kors,Saks Fifth Avenue OFF 5TH,Ted Baker,The } \\
\text { Kooples,Tory Burch,Tumi,Vince Camuto }\end{array}$ & Outlet Mall \\
\hline Rideau Centre & 10 & $\begin{array}{l}\text { Coach, Kate Spade,Lacoste,Massimo Dutti,Michael } \\
\text { Kors,Nordstrom,Stuart Weitzman,Ted Baker,Tiffany and } \\
\text { Co.,Tumi }\end{array}$ & $\begin{array}{l}\text { Major } \\
\text { Downtown Mall }\end{array}$ \\
\hline Square One & 10 & $\begin{array}{l}\text { Ann Taylor,Coach,Kate Spade,Lacoste,Massimo Dutti,Michael } \\
\text { Kors,Salvatore Ferragamo,Stuart Weitzman,Tory Burch,Tumi }\end{array}$ & $\begin{array}{l}\text { Traditional } \\
\text { Shopping Centre }\end{array}$ \\
\hline
\end{tabular}




\subsubsection{Thiessen Polygons}

Thiessen polygons were only created for the Toronto CMA as it is the only CMA that had more than a couple of locations each containing more than ten foreign high-end retailers. Six retail locations were used to create the Thiessen polygons: Yorkville, Sherway Gardens, Square One, Toronto Eaton Centre, Toronto Premium Outlet, and Yorkdale Shopping Centre. The Thiessen polygons were created in Alteryx (Version 11.0), following the methodology of Griffiths (2016). The first step was importing both the CMA shapefile from the Canadian census and the "Top_RetailLocations" shapefile created in the aggregation locations step. The CMA shapefile was given a filter so that only the Toronto CMA was included. The location shapefile was spatially joined to the CMA file to only include points that fall within the Toronto CMA. The trade area tool was used next to create a $100 \mathrm{~km}$ circular trade area around each point with the "Eliminate Overlap" option chosen. The $100 \mathrm{~km}$ was chosen as the resulting circular trade areas would go beyond the boundaries of the Toronto CMA. The eliminate overlap option is the key part as it will eliminate any overlap between the circles thus resulting in Thiessen polygons. The "Spatial Process" tool was then used to create the intersection between the circular trade areas and the Toronto CMA resulting in the Thiessen polygons covering only the Toronto CMA boundaries. This process could also be performed using the Thiessen polygon function in ArcMap (Version 10.0), however the data were already prepared in the Alteryx (Version 11.0) environment. The resulting trade areas can be seen in Figure 3.1. 


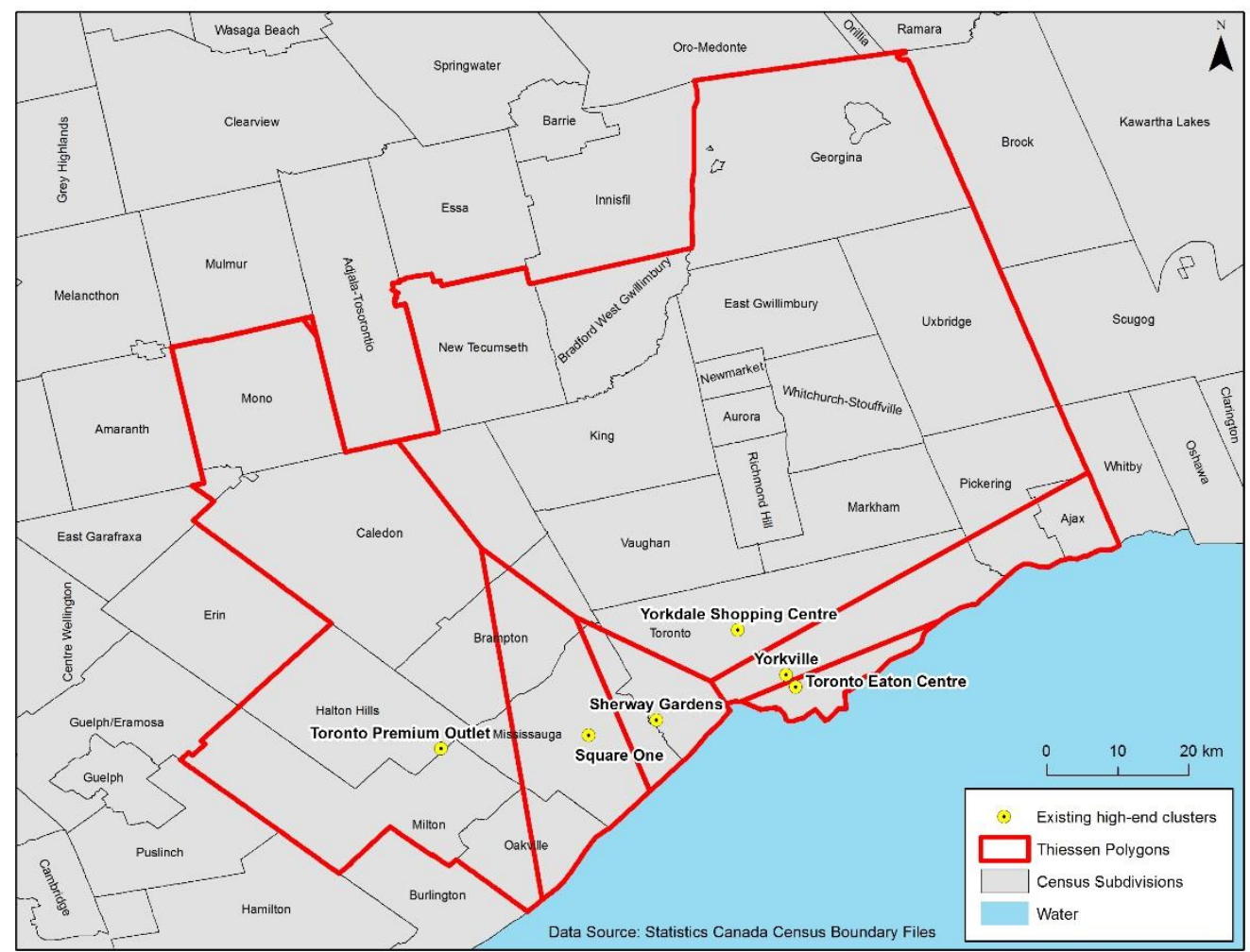

Figure 3.1: Thiessen polygons for Toronto CMA

\subsubsection{Drive Time Trade Areas}

When modeling a road network, it is important to include both the physical parts of the road and the time it takes to travel from one place to another. The network data set from DMTI Spatial Inc. was been built for the entirety of Canada using their various road datasets. Using this dataset allows the road network to be modelled correctly within the ArcMap (Version 10.0) environment. With the road network already built, the network analyst toolbar can be used. The network analyst toolbar allows a user to create various outputs based on a road network layer and a set of points. There are several options to choose from depending on what output one wants or scenarios one would like to model. To create the drive time trade areas, the "Create New Service Area" option was chosen from the network analyst toolbar. The top retail locations, nine in total, were loaded in as facilities. To create the trade areas, several parameters needed to be set. For the analysis settings, the impedance was set to drive time (minutes) with the default breaks at 15 and 20. This creates a 15-min and 20-min trade area for each of the facilities. The trade areas were created towards the facility for the direction of 
travel since people drive to the facility to shop. As there are multiple facilities in the model, each trade area generated will have an individual polygon for each of the drive times specified. Overlap of the trade areas is allowed as we would like to determine the potential customer base for each of the locations. Overlap amongst the trade areas is of concern in the Toronto CMA, the other CMA's do not have any overlapping trade areas currently. Once the analysis is complete, there is potential for overlap to occur in other CMA's due to the inclusion of new locations. The trade areas do not represent the actual customer base but the potential customer base, therefore overlap is acceptable. The drive time trade areas for each of the locations chosen can be found in the following figures, Figure 3.2 to Figure 3.10. The resulting polygon from the network analyst was exported to a shapefile.

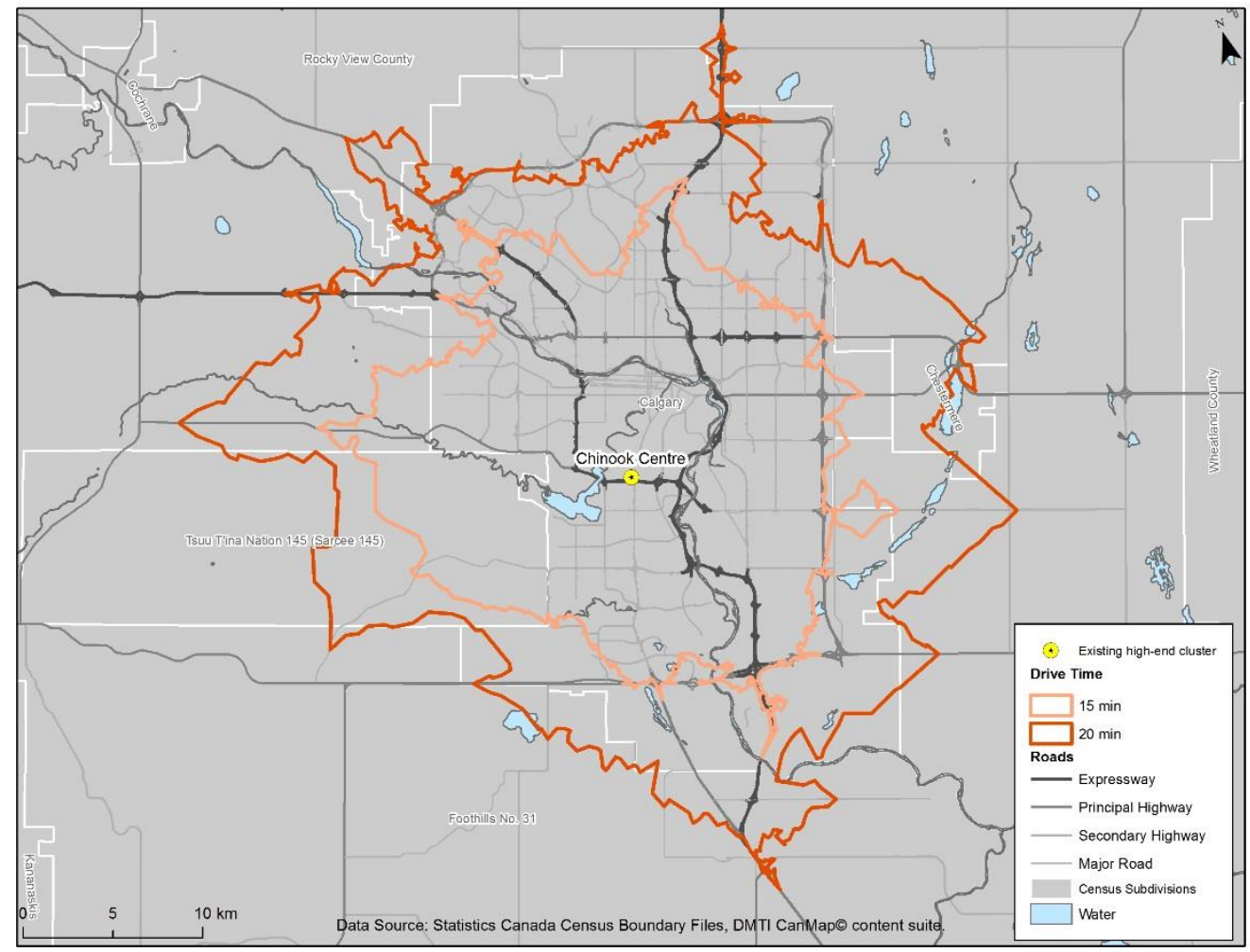

Figure 3.2: Drive time trade area for Chinook Centre, Calgary. 


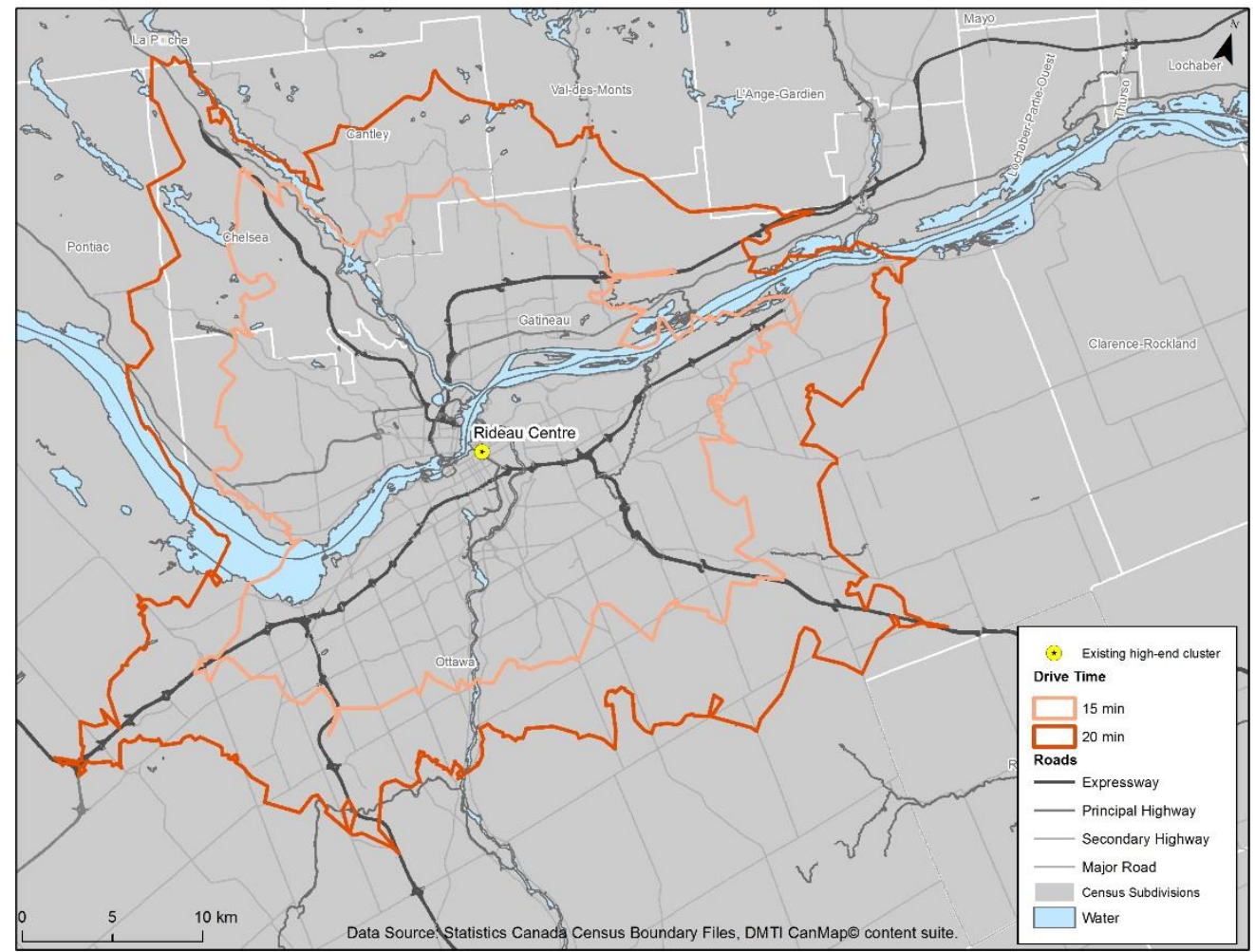

Figure 3.3: Drive time trade area for Rideau Centre, Ottawa.

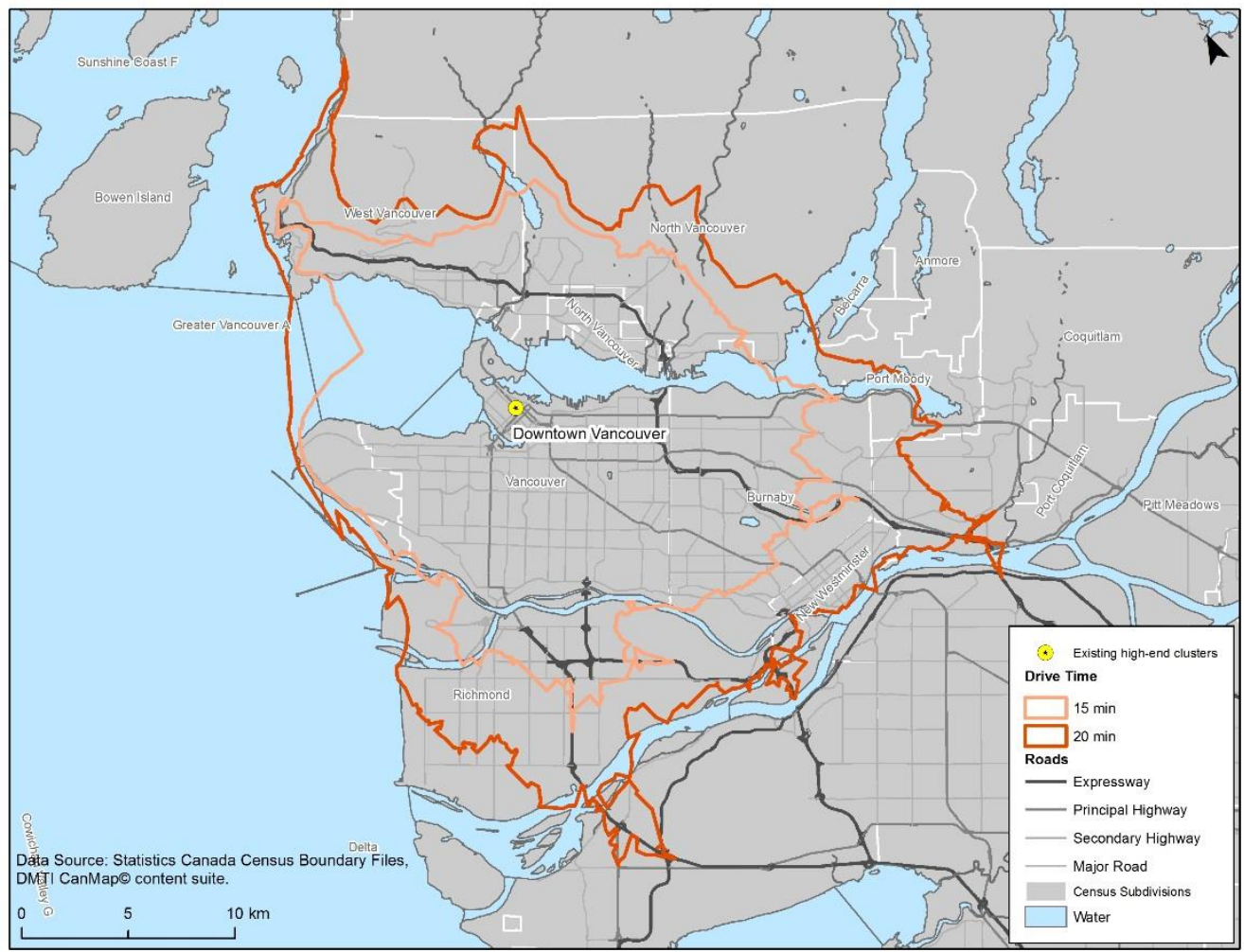

Figure 3.4: Drive time trade area for downtown Vancouver. 


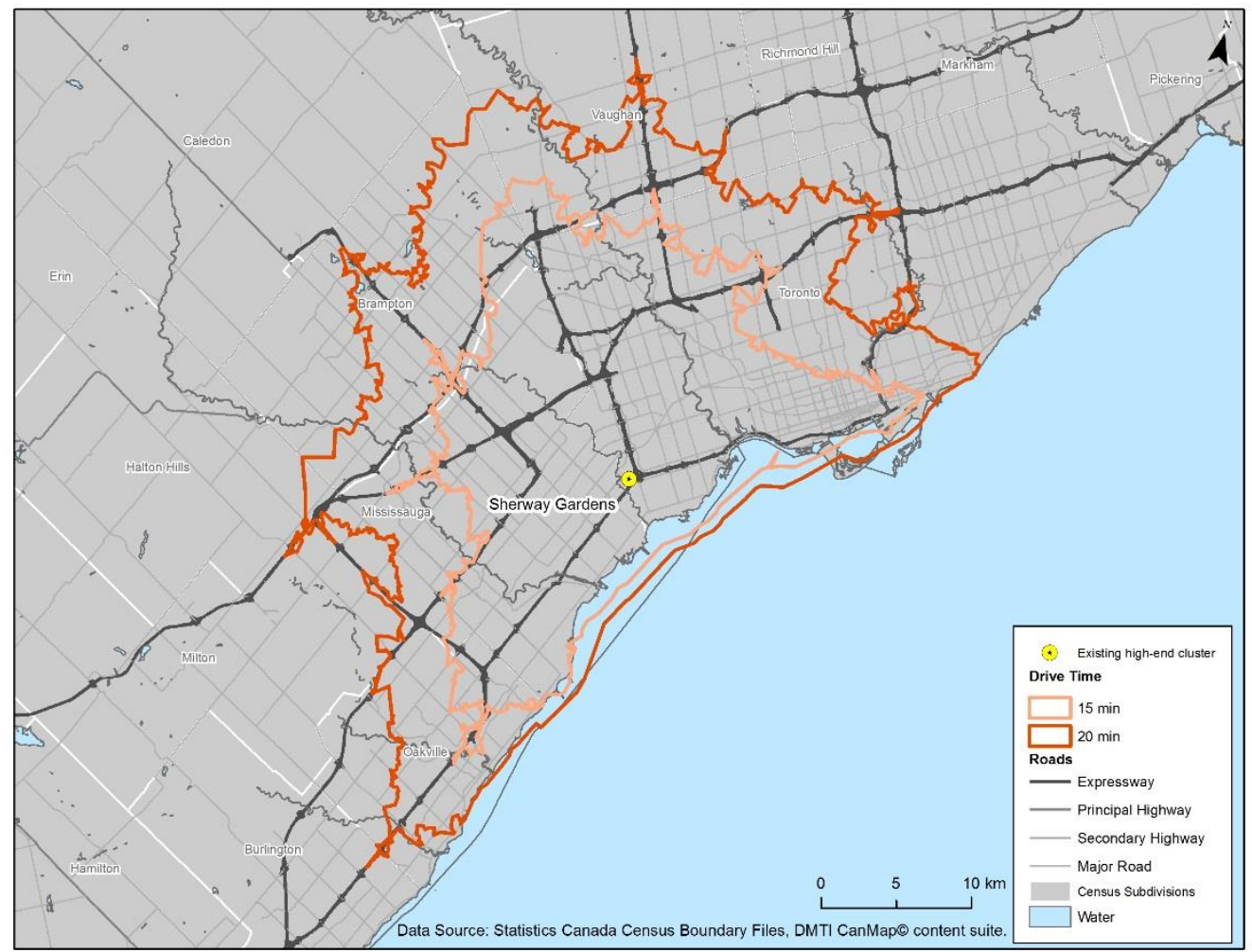

Figure 3.5: Drive time trade area for Sherway Gardens, Toronto.

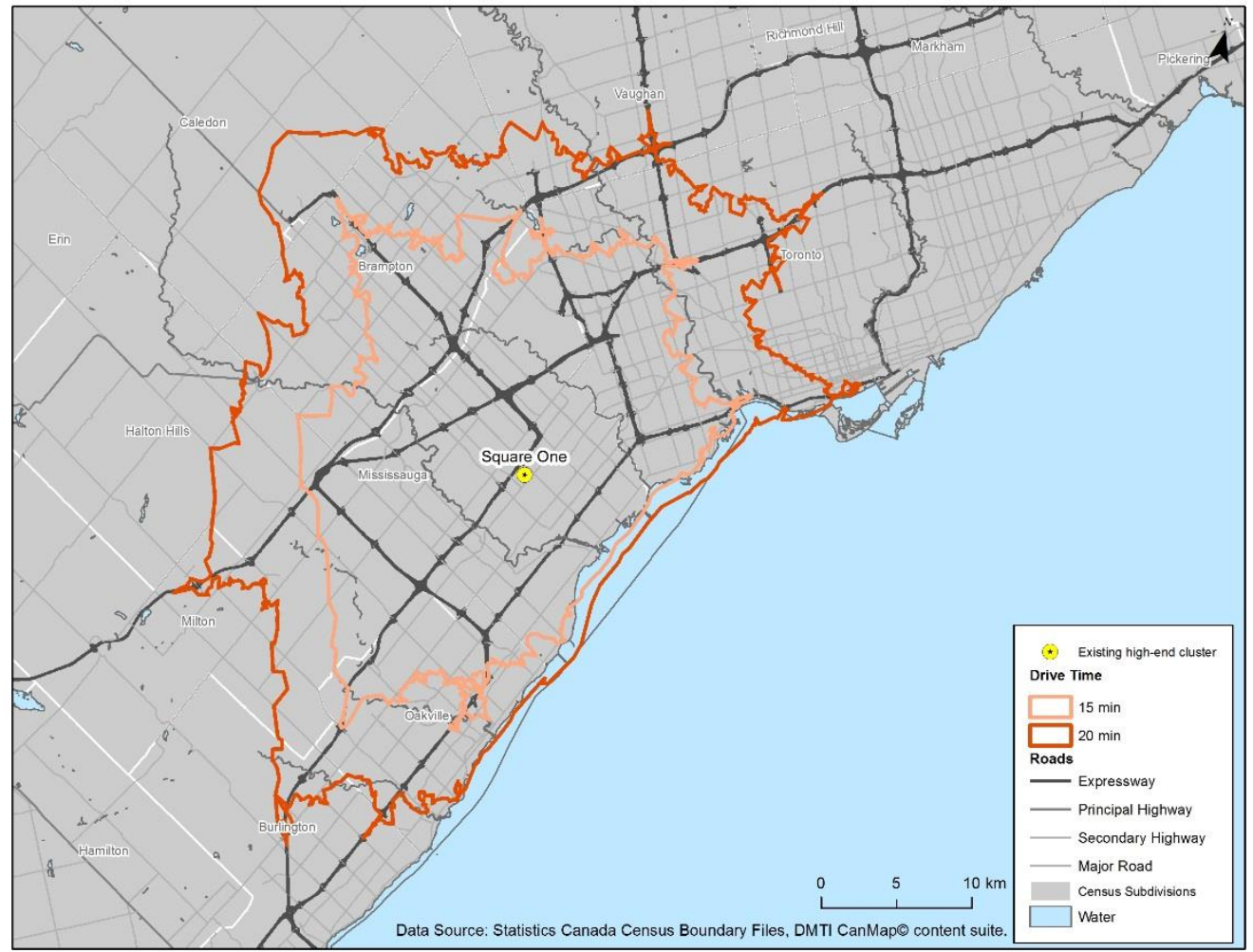

Figure 3.6: Drive time trade area for Square One, Mississauga. 


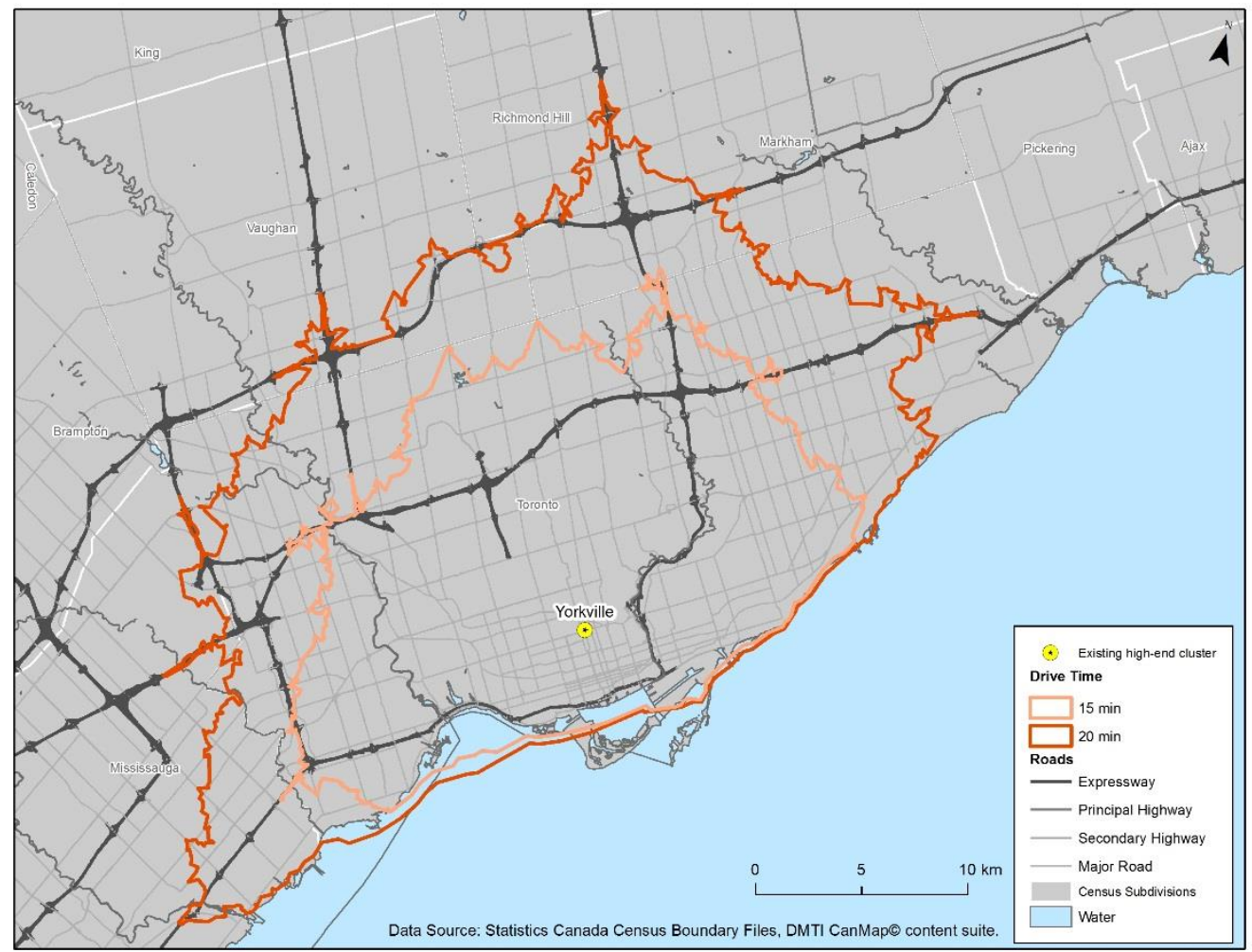

Figure 3.7: Drive time trade area for Yorkville, Toronto.

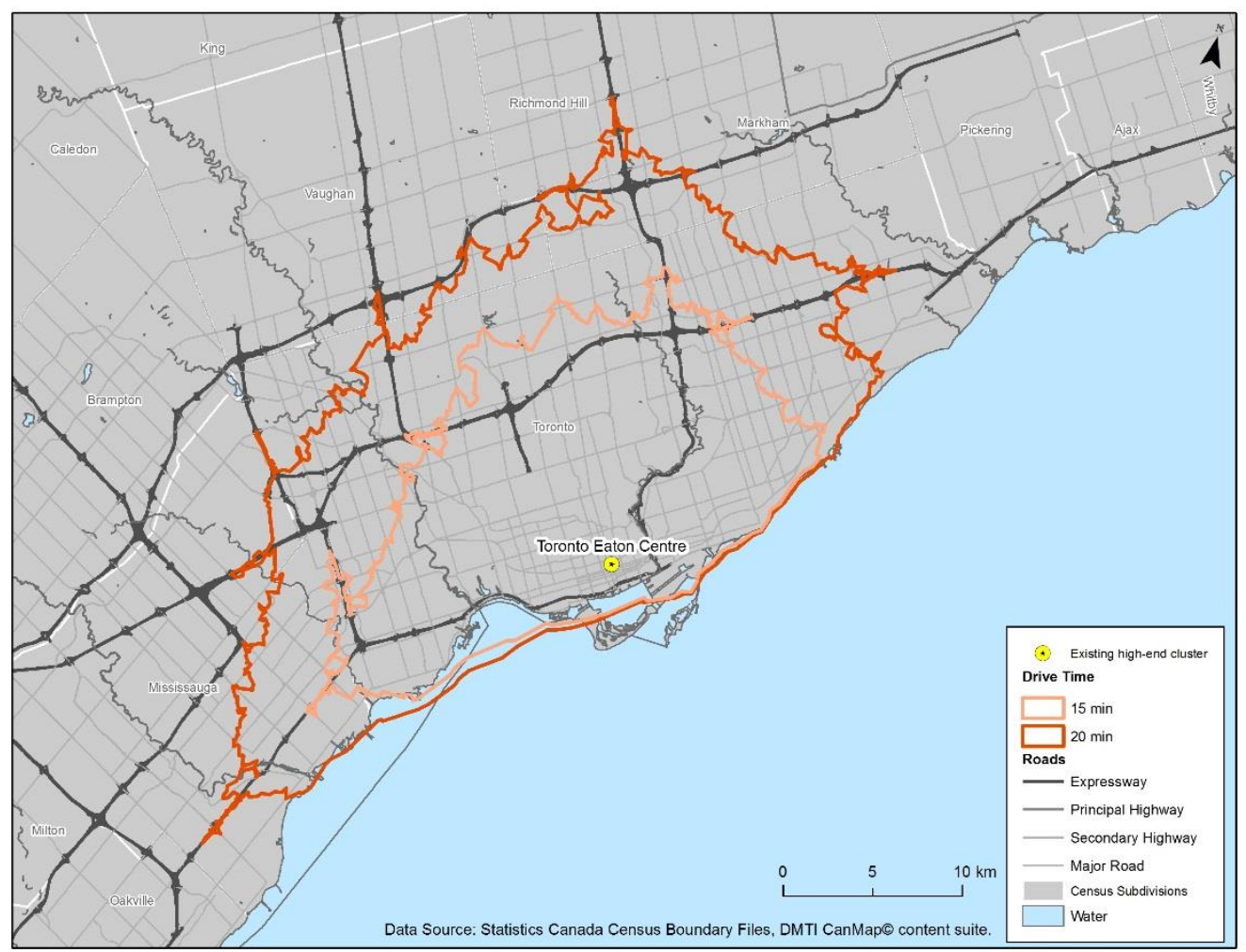

Figure 3.8: Drive time trade area for Toronto Eaton Centre, Toronto. 


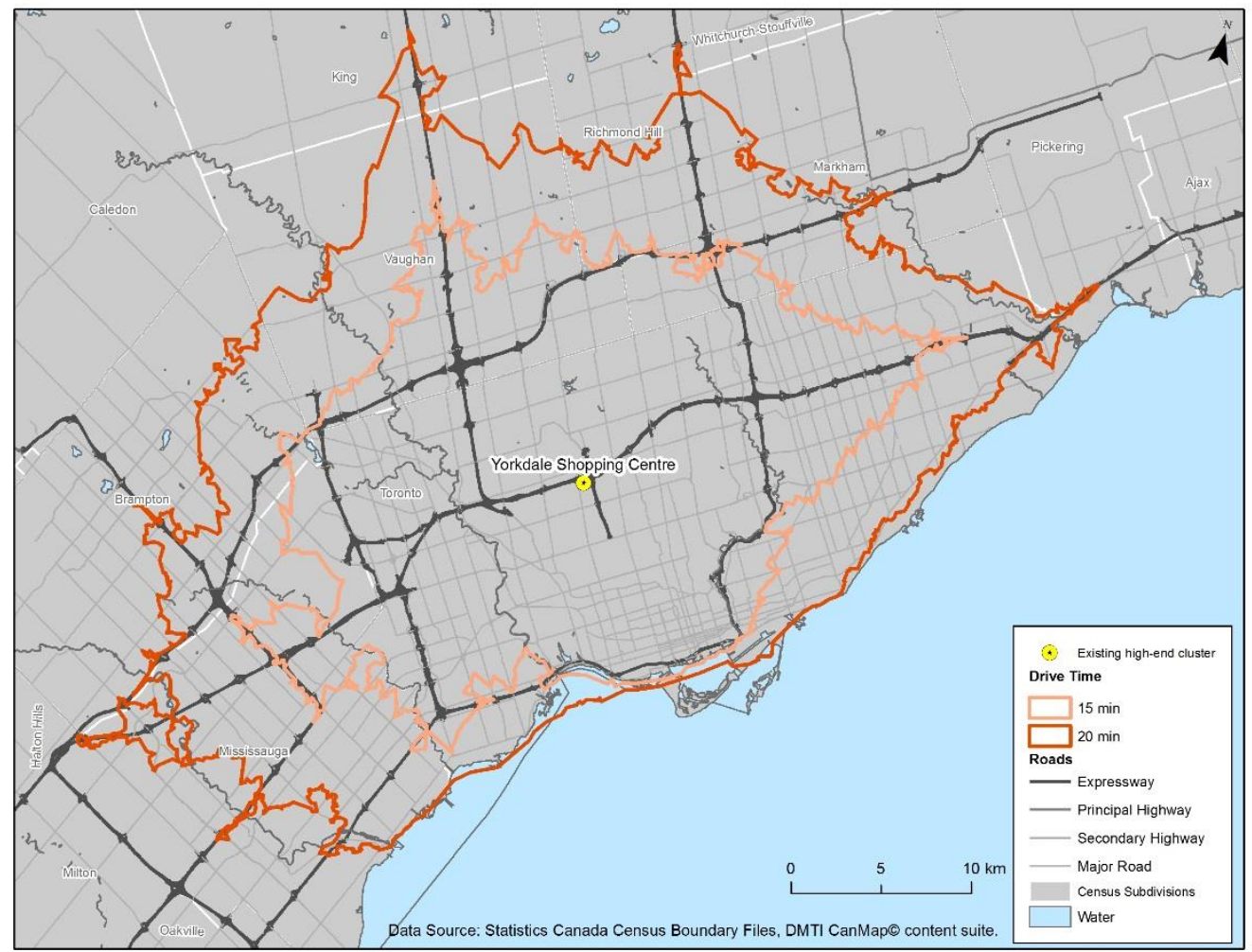

Figure 3.9: Drive time trade area for Yorkdale Shopping Centre, Toronto.

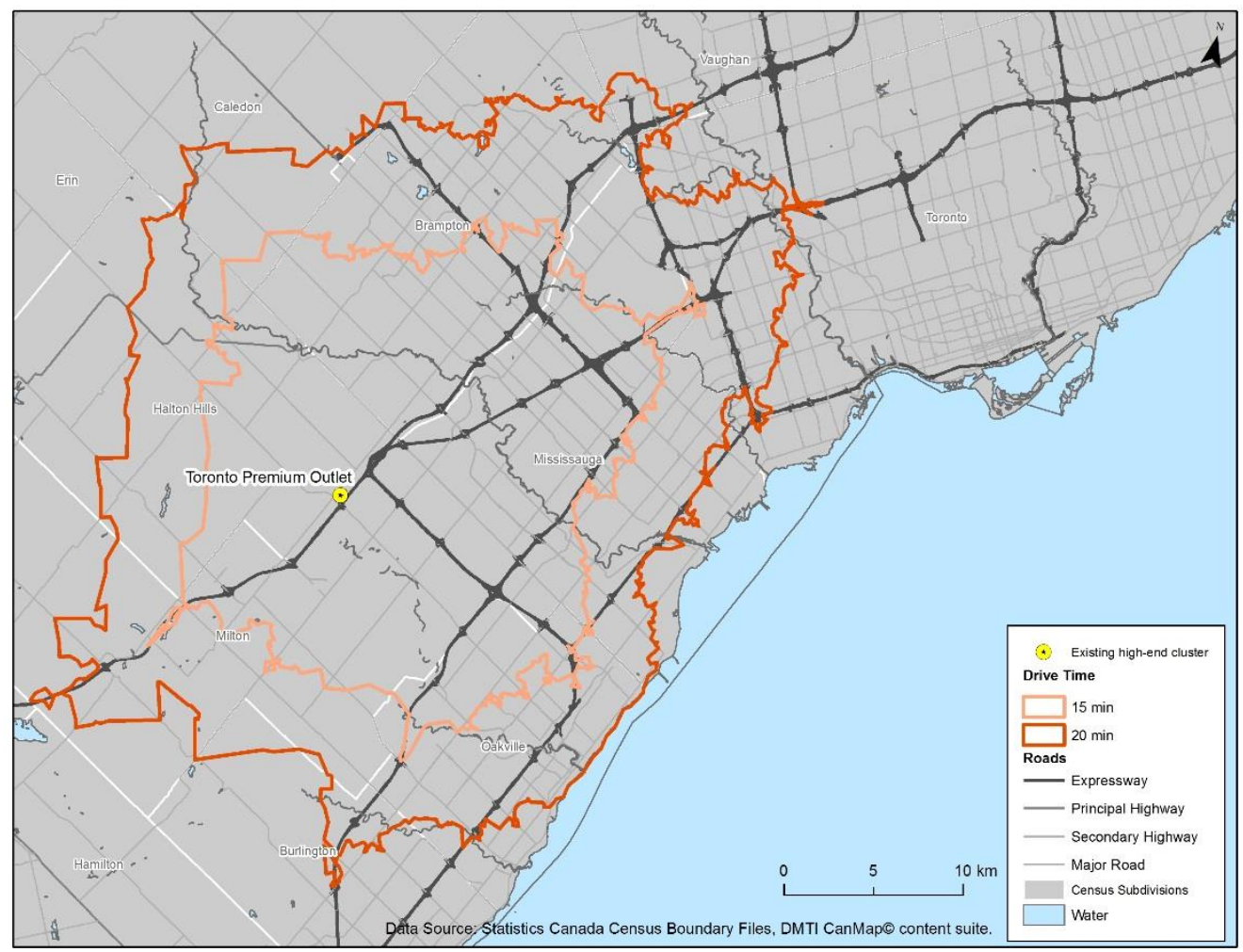

Figure 3.10: Drive time trade for Toronto Premium Outlets, Halton Hills. 
The exported polygons were brought into Alteryx (Version 11.0) to determine what census tracts fall within each trade area. The trade area polygons were joined to the census tract shapefile using the spatial match tool. The intersect option was chosen for the join method as the tool will output the intersection of the two objects. Three spatial objects are output from the tool: the first being the trade area outline, the second all the matched census tracts, and third all the census tracts but only the areas that are within the trade area. This results in the third spatial output having a portion of a full census tract. For these areas, appending the demographic data for the entire census tract would disproportion the data as only a section of that census tract is present within the trade area. To get a more accurate representation of what is present within the trade areas, the percentage of the census tract that falls within the trade area must be determined. The area for all the census tracts and the area for the census tracts within the trade areas was calculated using the spatial info tool. Then using the formula tool, a field called "Area_Weight" was added that calculated the percentage by dividing the area of the census tracts within the trade area by the area of the complete census tract. Figures 3.11 to 3.19 show the census tracts that are within each of the trade areas, the existing high-end clusters and other locations as well for context.

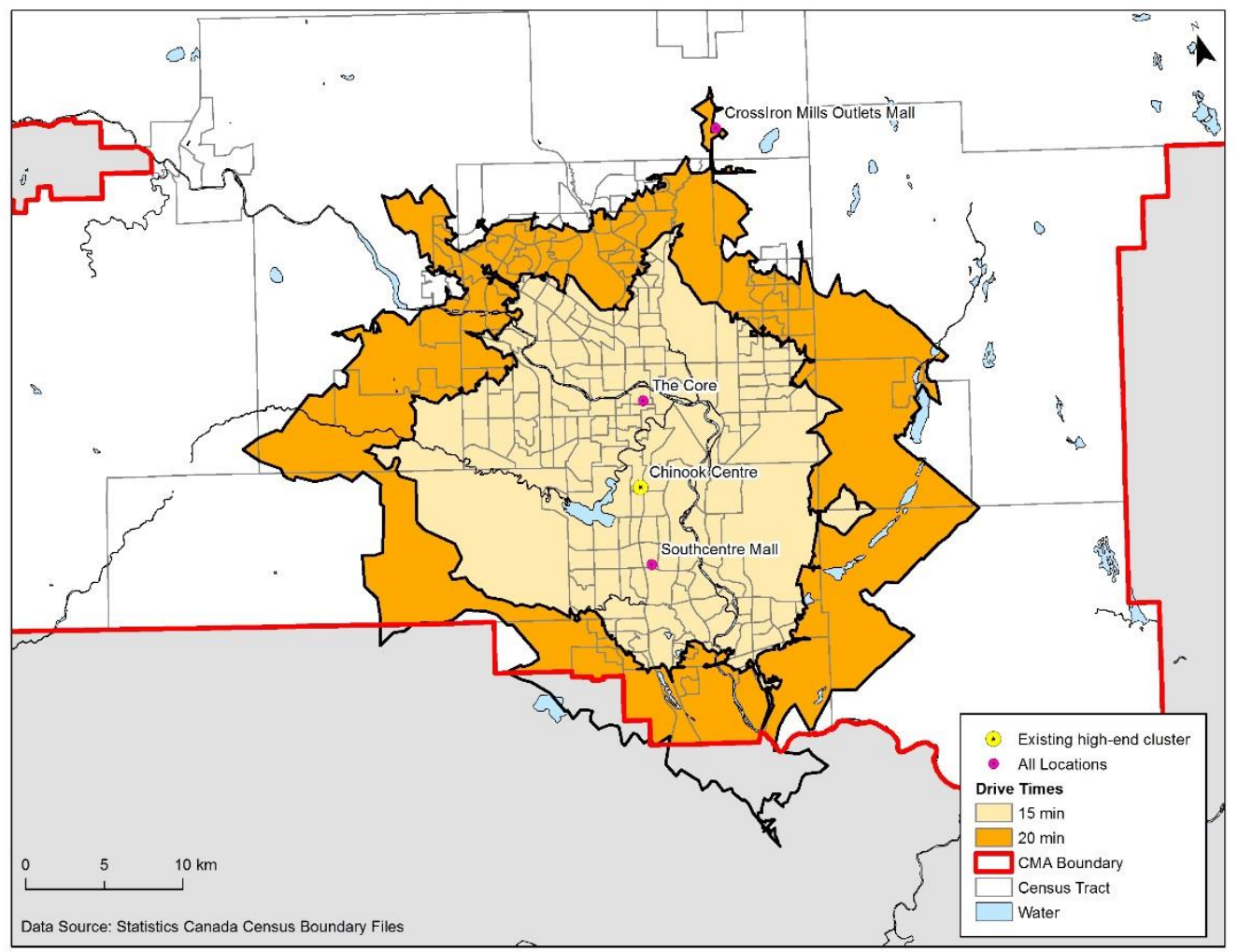

Figure 3.11: Census tracts in the drive time trade areas for Chinook Centre, Calgary. 


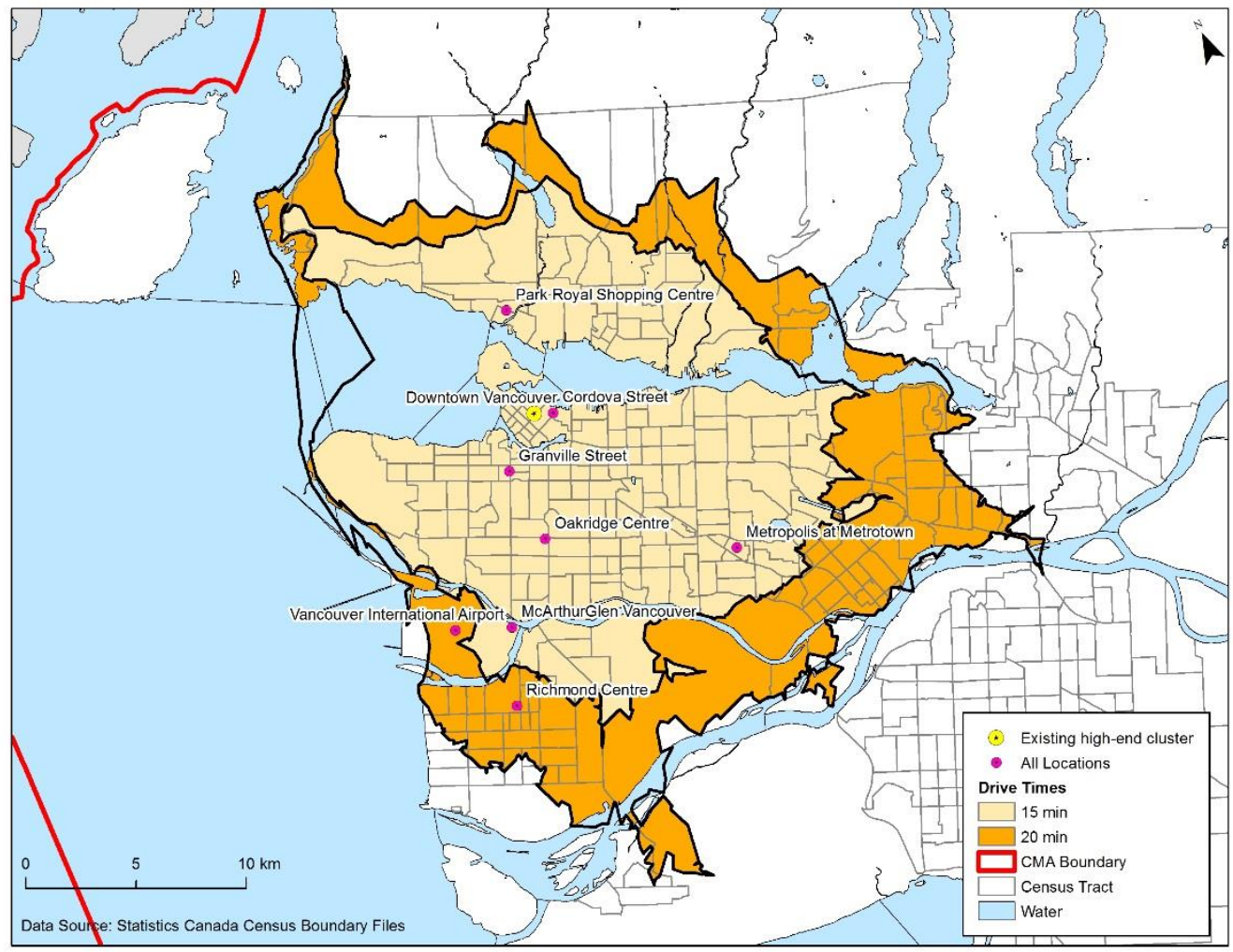

Figure 3.12: Census tracts in the drive time trade areas for downtown Vancouver.

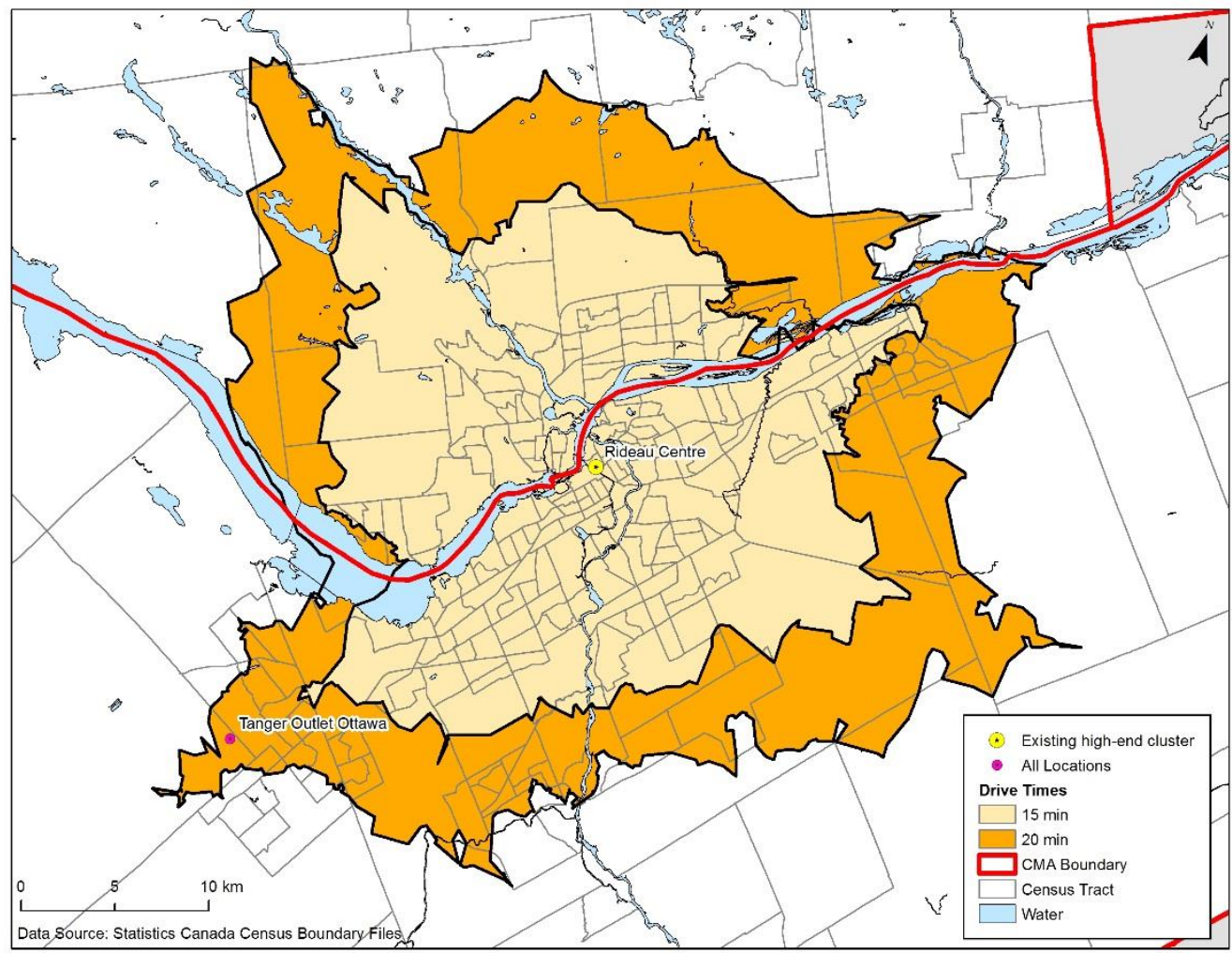

Figure 3.13: Census tracts in the drive time trade areas for Rideau Centre, Ottawa. 


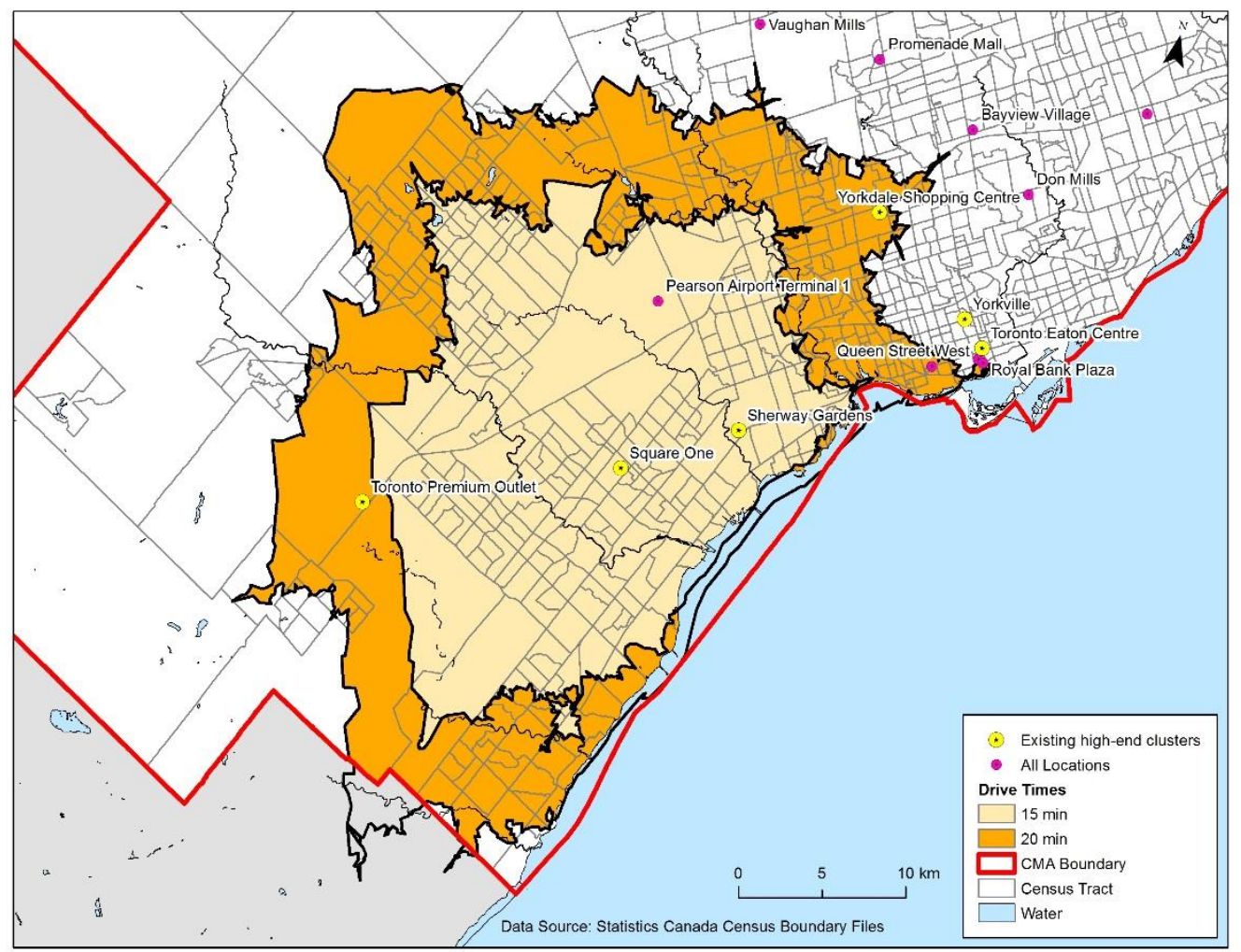

Figure 3.14: Census tracts in the drive time trade areas for Square One, Mississauga.

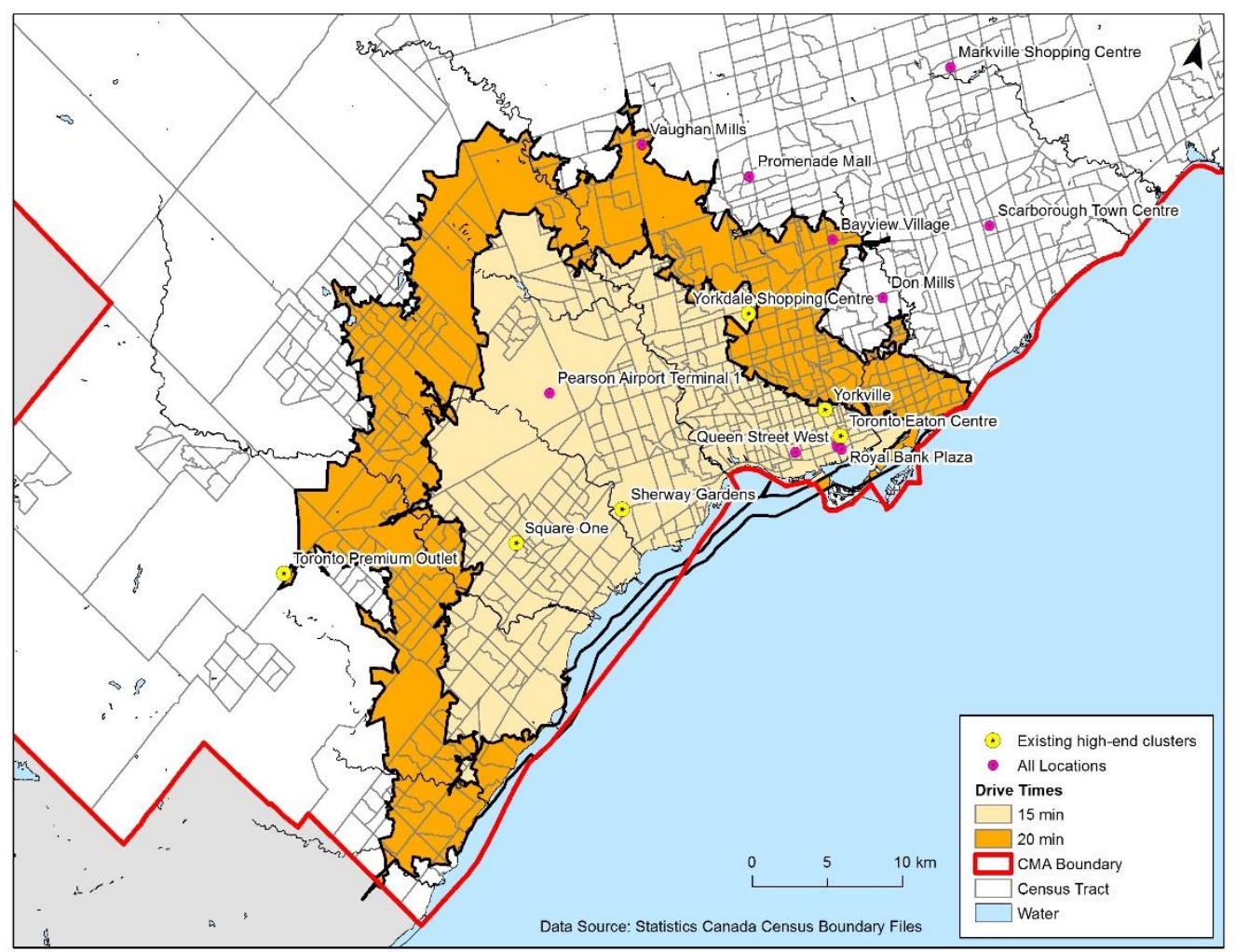

Figure 3.15: Census tracts in the drive time trade areas for Sherway Gardens, Toronto. 


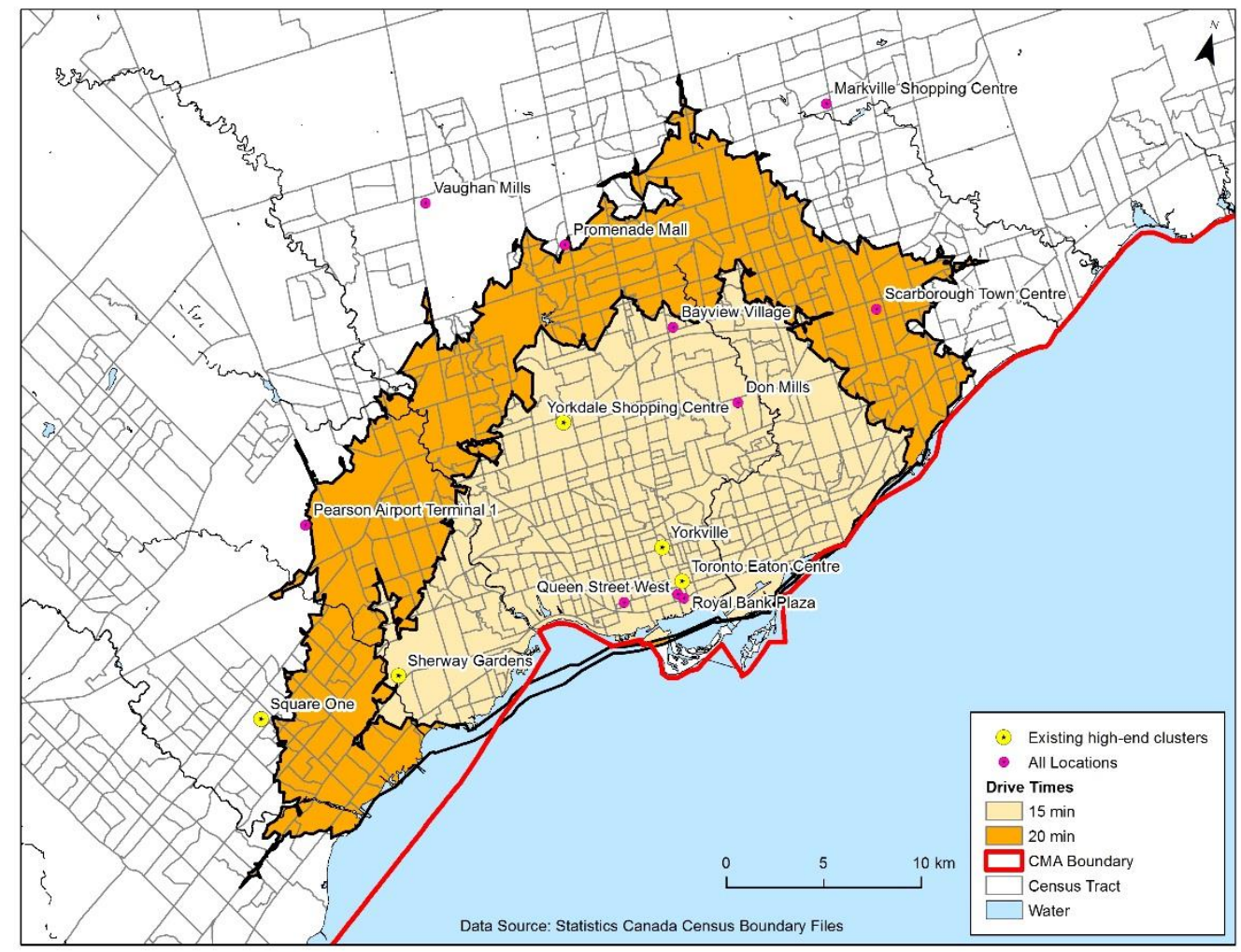

Figure 3.16: Census tracts in the drive time trade areas for Toronto Eaton Centre, Toronto.

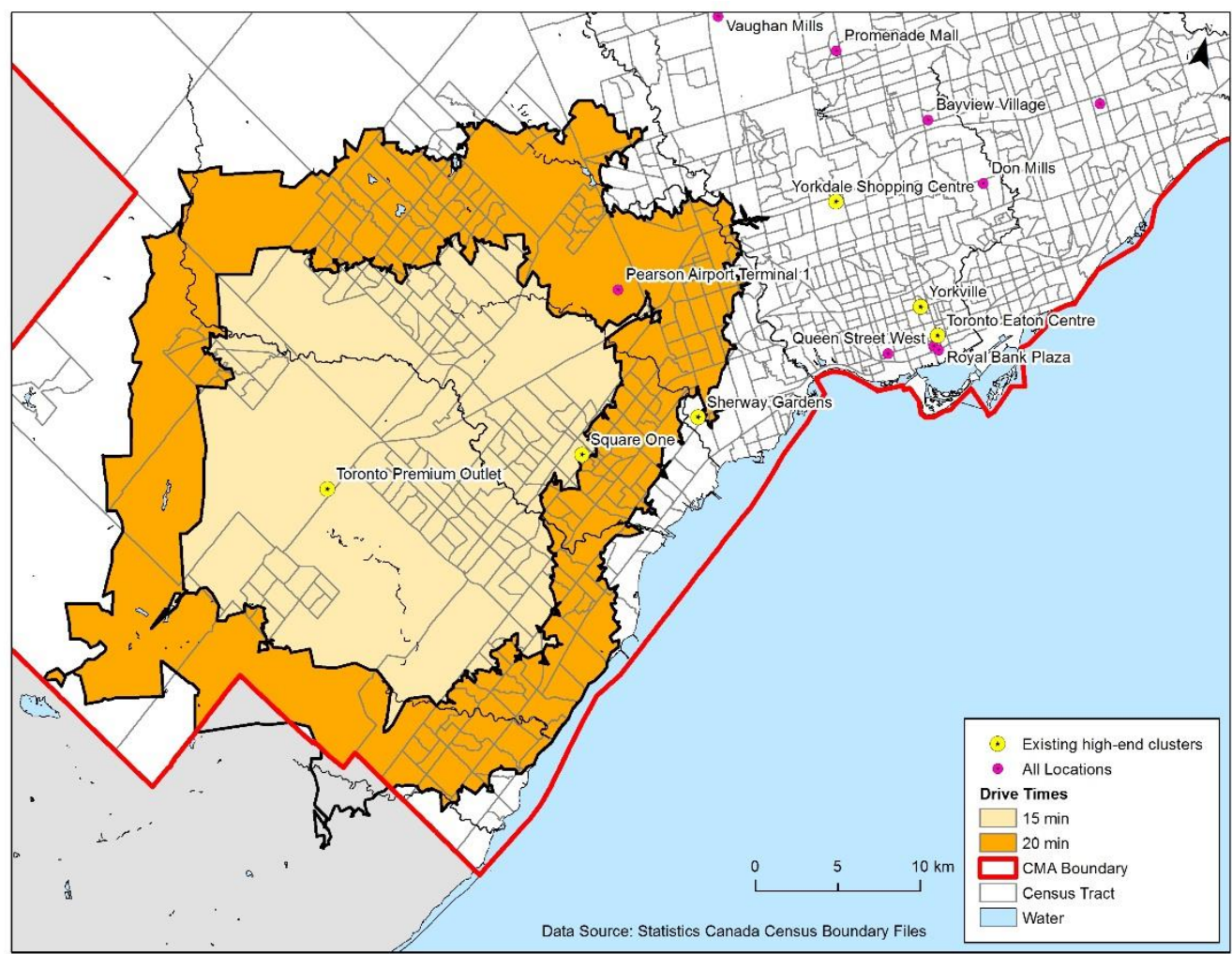

Figure 3.17: Census tracts in the drive time trade areas for Toronto Premium Outlets, Halton Hills. 


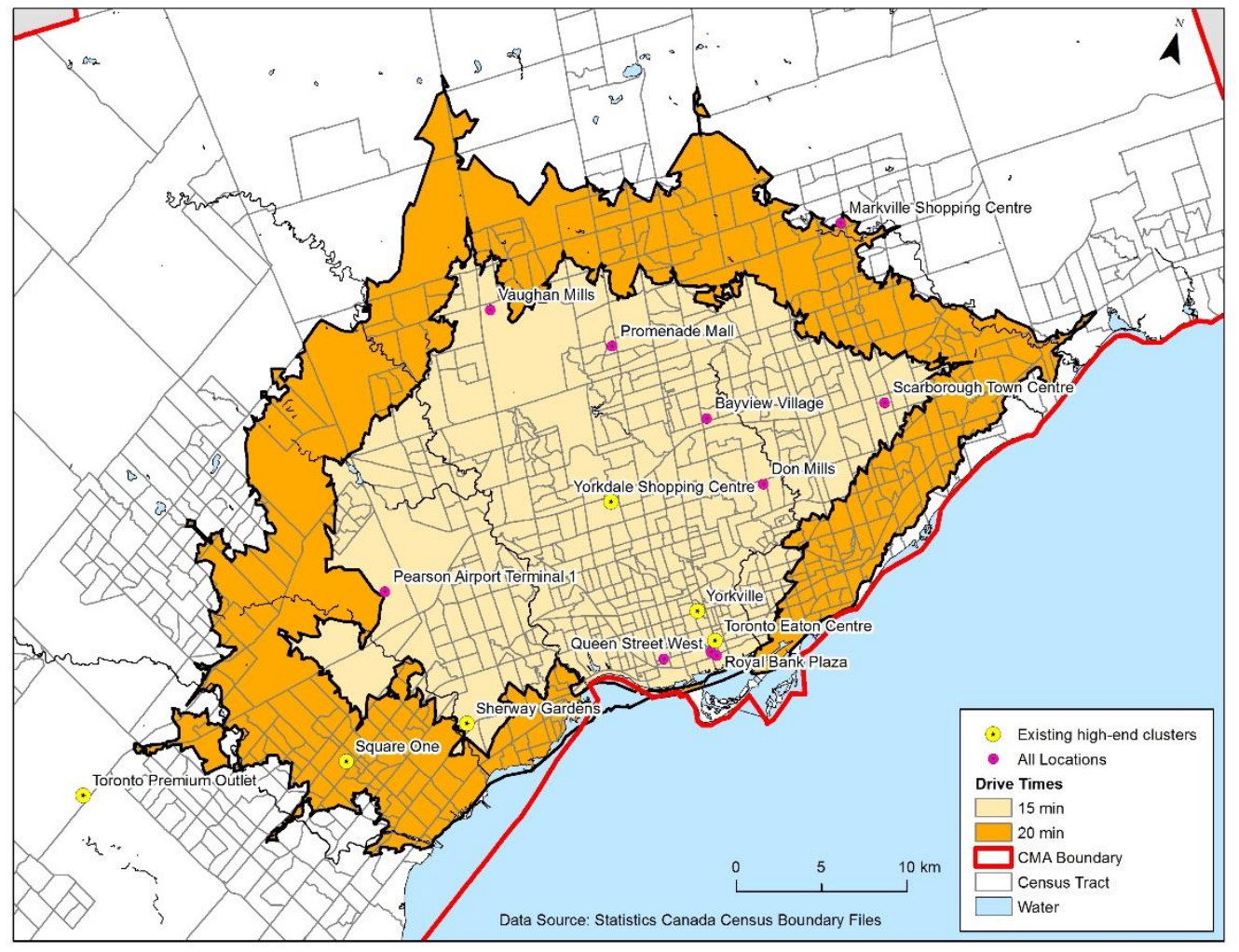

Figure 3.18: Census tracts in the drive time trade areas for Yorkdale Shopping Centre, Toronto.

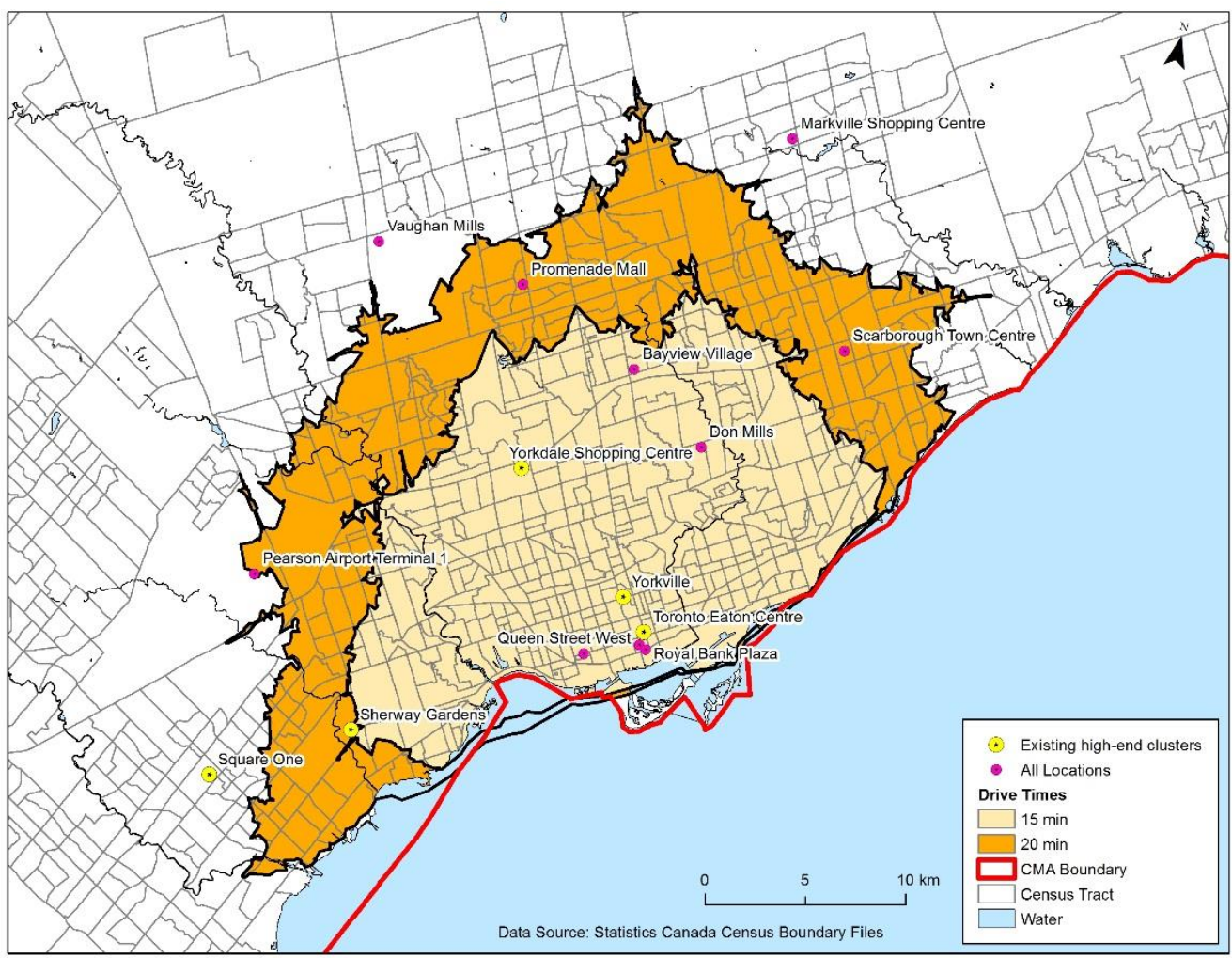

Figure 3.19: Census tracts in the drive time trade areas for Yorkville, Toronto. 


\subsubsection{Demographic Data Preparation}

The demographic data were prepared at the census tract level for all the CMA's included in the study. The data from Environics Analytics were brought into Alteryx (Version 11.0) and each of the variables was renamed to make shorter, simpler variable names. The income variables needed to be aggregated into smaller groups based on Canadian income levels. In total six household income level groups were created Low Income $(<\$ 40,000)$, Low-Middle Income $(\$ 40,000$ - $\$ 60,000)$, Middle Income $(\$ 60,000$ - $\$ 90,000)$, Upper-Middle Income $(\$ 90,000$ - \$125,000), High-Low Income $(\$ 125,000$ - \$150,000), High-Middle Income $(\$ 150,000$ $\$ 175,000)$, and High-High Income $(\$ 175,000>)$. A “Not Married” variable was also created that included the variables Separated, Divorced, and Widowed. The variables that were used to create the aggregated variables were removed from the variable list, the list was then exported to be used as the base data. These base data will be used later to create a demographic profile of the trade areas. The next step was to make all the base data variables relative. This was done by dividing each variable by its base variable then multiplying it by 100 to get the percentage. For example, the male and female population variables were divided by their respective total male and female populations. The average household income variable was calculated by dividing the aggregate household income by the total number of households. The formulas used to create each relative variable are outlined in Appendix A, Table A3. The base variables were then removed from the variable list, and the list was exported to be used as the relative data. The relative data will be used as the input for the k-means cluster analysis to determine potential locations for high end retailers.

The trade area shapefile at the census tract level, was brought into Alteryx (Version 11.0) and joined to the base data on the census tract id field. The "Multi-field Formula" tool was used to multiply each field by the "Area_Weight" field all at once. The "Multi-field Formula" can apply a single formula to any field selected, all the variable fields were selected for the tool. The resulting variables were given a prefix of " $W$ " to indicate that the weight had been applied. The weighted variables were then made into relative variables by using the same formulas that were applied previously to the base variables. The relative variables were selected and exported to an Excel file as "Relative Trade Area Data". 


\subsubsection{K-Means Cluster Analysis}

To determine potential locations for foreign high-end retailers to expand into, the geodemographics segmentation approach was used. This approach uses census data to create small groups that share similar characteristics. Smaller geographic levels, like census tracts, are best used for this type of segmentation. To perform this grouping, the K-means cluster analysis is most commonly used as it is simple to set up and can be rerun with ease. The requirements for the K-means cluster analysis are that the data must be standardized (Leventhal, 2016). To standardize the variables, the relative data were brought into SPSS. The "Descriptives" tool was used to standardize the variables. After the tool had run, the resulting standardized variables had a " $Z$ " added to the beginning of their variable. The most challenging step of K-means cluster analysis is determining the number of groups that the data should be divided into. There are several methods that are employed to determine the number of clusters: rule of thumb, elbow method, information criterion approach, silhouette method, and cross validation (Kodinariya \& Makwana, 2013). Several of these methods require the use of advanced statistical packages and processes. The elbow method was employed for this study as it is the oldest method used, and can be performed easily within the SPSS environment. The elbow method uses the agglomeration schedule from the hierarchical clustering method to determine the ideal number of groups. The elbow occurs when the jump in coefficients from one stage to the next starts to even out. When the coefficient values from the agglomeration schedule are plotted against the stage number, the reduction in coefficient values will make it look like the plot has an elbow (Kodinariya and Makwana, 2013). To determine the ideal number of groups the hierarchical clustering tool was run on all the standardized variables. The agglomeration schedule was exported to Excel. The last 100 stages with their coefficient values were selected from the agglomeration schedule; these represent the first 100 groups that the data were divided into. To determine the number of groups from the stage number, each stage number is subtracted from the total number of stages. The newly added "Number of Groups" field was used to hold the number of group values for each respective stage number. The coefficient values were plotted against the number of groups, the elbow occurred around 4-6 clusters. Starting with 4 clusters, the K-means tool was used with all the standardized variables. The 
ideal cluster size was determined by looking at the "Number of Cases in each Cluster" table from the K-means output. At four clusters, each of the groups had a significant number of cases however, for five and six clusters one or two of the clusters had only one case in a cluster. Not all variables were included, the industry variables were removed from the K-means cluster analysis as they are too much like the occupation variables. This was determined after testing all the variables in the K-means cluster analysis and finding that clusters did not form well. Different combinations of variables were tested until the final selection of including the occupation variables over the industry variables was chosen. This was based on how the clusters were formed and the resulting cluster characteristics. With four clusters chosen as the final number of clusters, the K-means tool was run again with the option to save the cluster assignments selected. The final dataset, with the cluster assignments was exported as a DBF file with the CT id and the cluster number. The cluster numbers along with the census tract id was joined back to the census tract shapefile on the census tract id in Alteryx (Version 11.0), then was exported to a shapefile to be used in the ArcMap (Version 10.0) software. 


\section{Chapter 4 - Analysis and Results}

\subsection{Trade Area Demographics and Household Spending Habits}

The demographics and household spending habits for the trade areas will be presented at the individual level and an aggregate level that includes all trade areas. The individual level will be taken from the relative data which contains the percentages for all the variables and the average household income. The aggregate level will be derived from the raw data. The CMA values will also be reported as an aggregate of all the CMAs in the study. The demographic and household spending habits will focus on the aggregate trade area and the CMA level. The individual level shows little variation among the variables within their respective sections. Any significant variation at the individual level are addressed in their respective section below. The full data list at the individual level can be found in the appendix in tables A4-A14.

\subsubsection{Population and Age}

The core age range present within the trade areas is 25 to 59 , as they make up over $50 \%$ of the population for both the male and female population, as seen in Figure 4.1. The most abundant age range for the female population overall was ages 30 to 34 with $9 \%$ of the total female population followed by ages 25 to 29 with $8 \%$ of the total female population. The male population displays the exact same pattern, ages 30 to 34 followed by 25 to 29 with $9 \%$ and $8 \%$ of the total male population respectively. When compared to the CMA, little difference can be seen in Figure 4.2. 


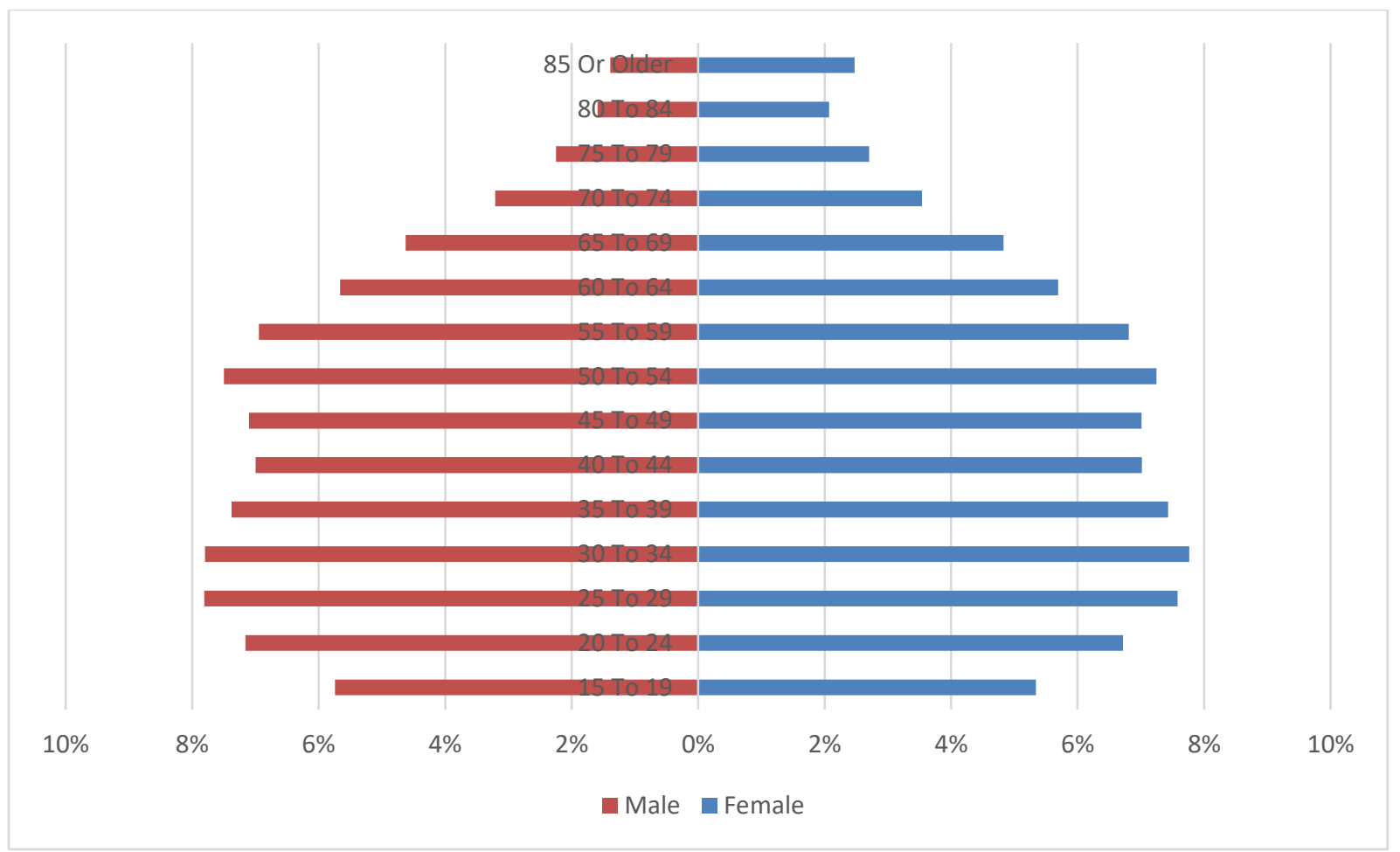

Figure 4.1: Female and male age distribution at the aggregate trade area level.

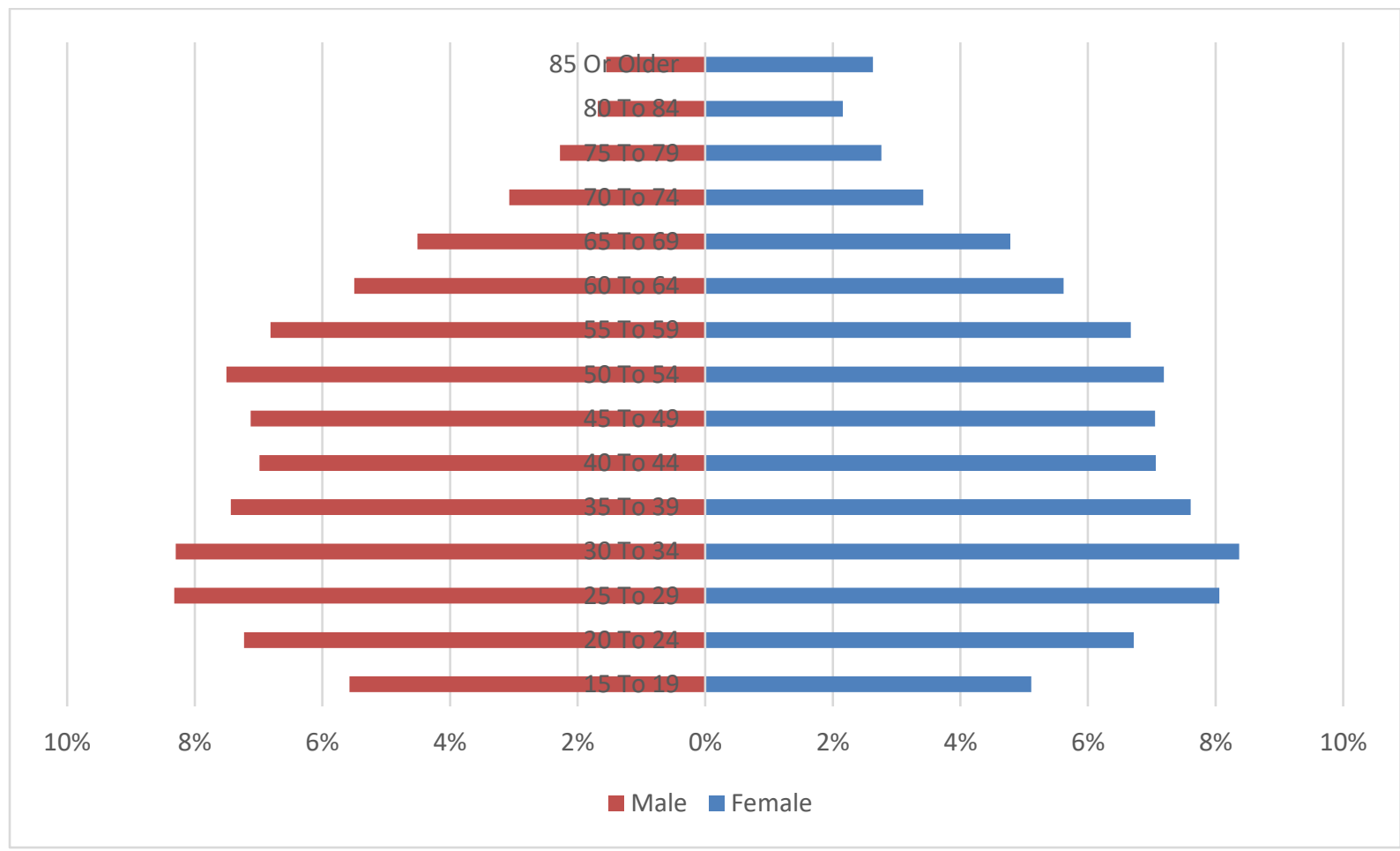

Figure 4.2: Female and male age distribution at the aggregate CMA level. 


\subsubsection{Marital Status}

Most of the population is married, followed by single, with not married in the minority, as seen in Figure 4.3. This pattern follows the age structure as the population ranges from young-adult (Ages 20-30) to mature-adult (ages 30-40). The young-adults are more likely to be single then start getting married once they transition into the mature-adult stages. At the CMA level, there are more married people and less single people compared to the aggregate trade area level.

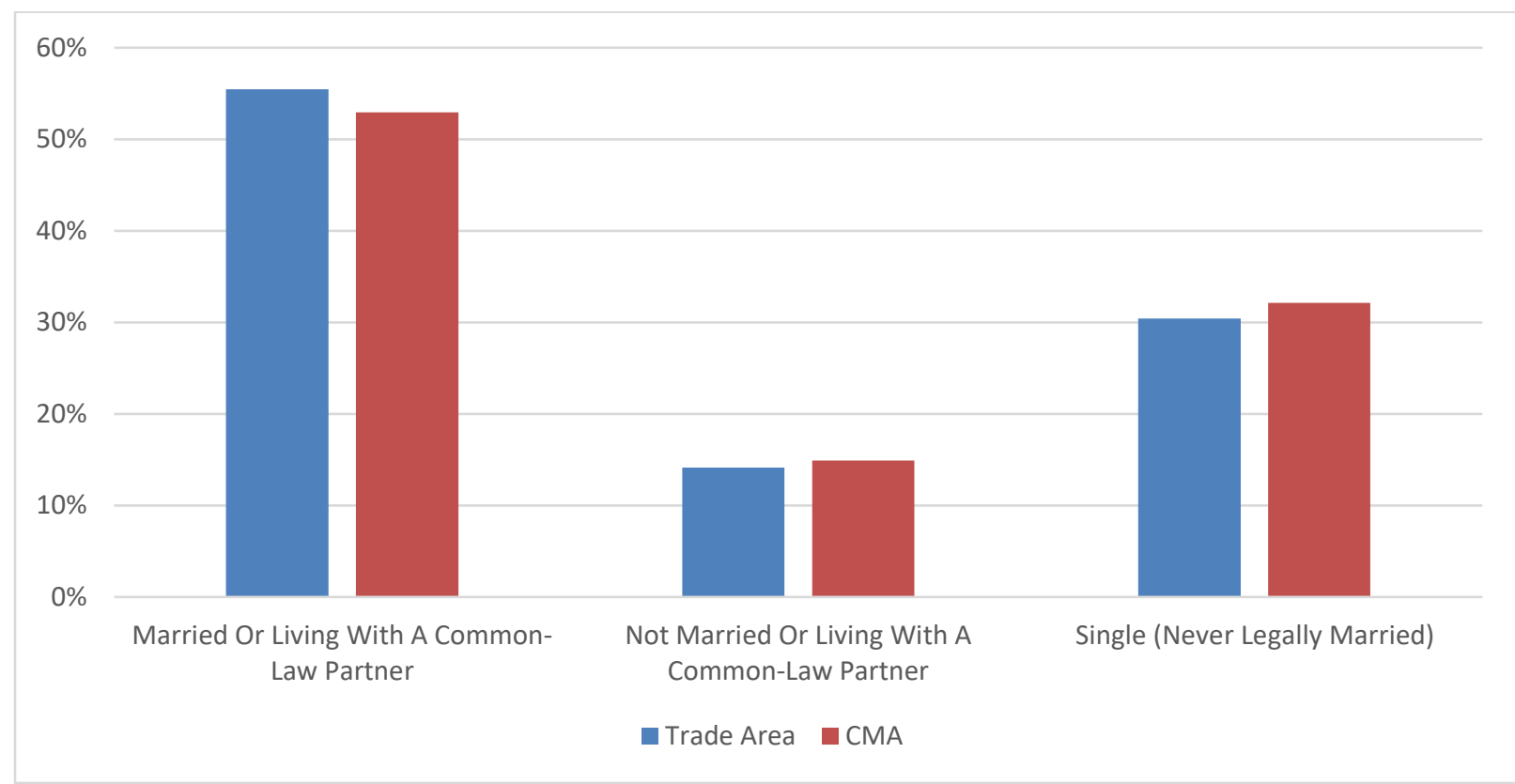

Figure 4.3: Marital status distribution at the aggregate trade area and CMA level.

\subsubsection{Education}

High school diploma and bachelor's degree are the two highest variables with $23 \%$ and $22 \%$ of the population respectively, as seen in Figure 4.4. This high instance of people with a high school diploma follows the percentages found at the CMA level. The trade areas have a higher percentage of people with higher education compared to the CMA. This shows that the people in the trade area have higher eduation levels. Higher education levels usually indicate higher income levels, which is our main customer characteristic. 


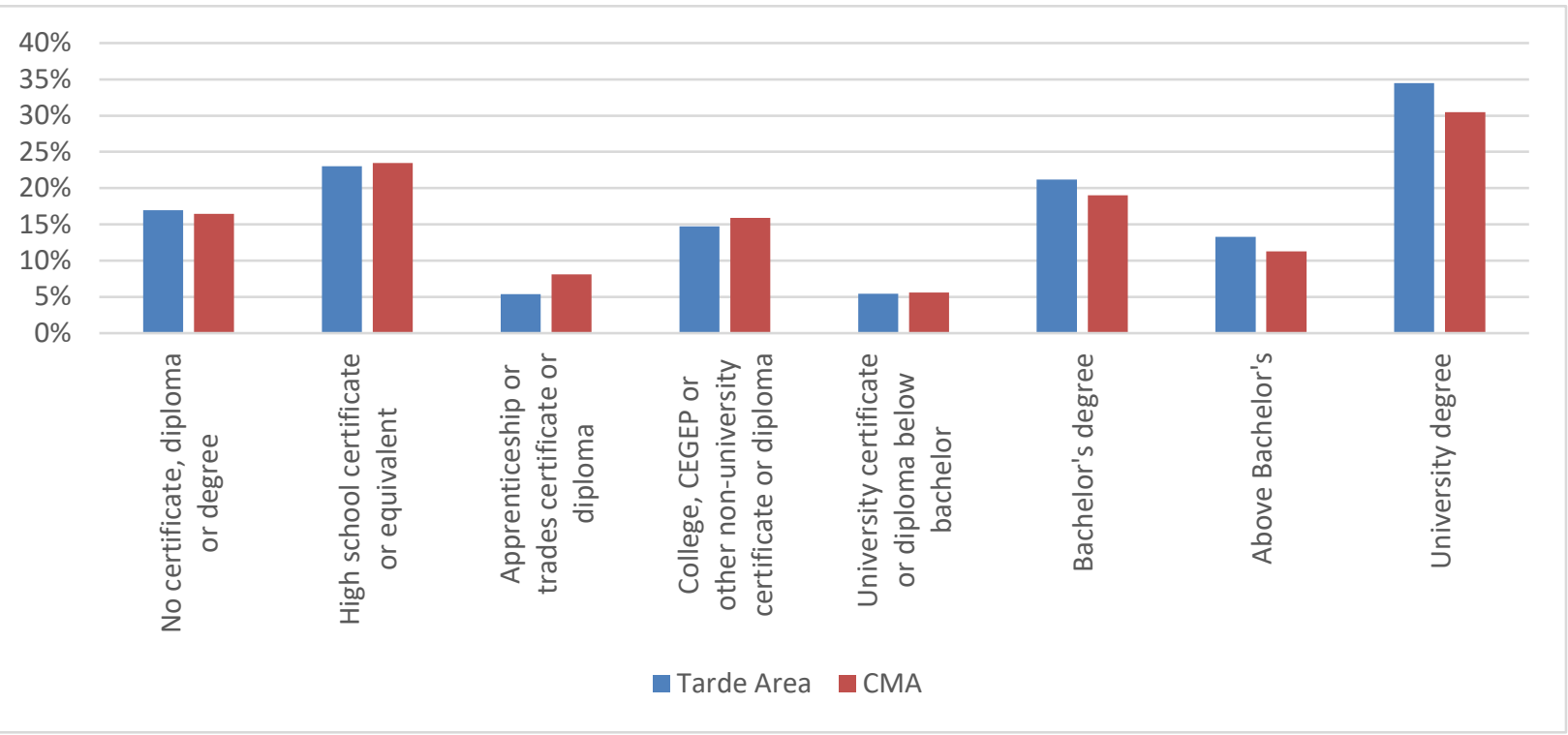

Figure 4.4: Education level distribution at the aggregate trade area and CMA level.

\subsubsection{Income}

Most of the population in the trade areas falls within the low to middle average household income ranges (less than $\$ 40,000$ to $\$ 90,000$ ), as seen in Figure 4.5. The average household income for all the trade areas was $\$ 107,764$. For the individual trade areas, Chinook Centre had the highest overall average household income at $\$ 138,002$ with downtown Vancouver the lowest overall at $\$ 96,444$ as seen in Figure 4.6. The high instance of married people and mature adults could explain the higher than average income levels present in the trade areas. When compared to the CMA level, the trade areas have higher percentages in the higher income level and lower percentages in the lower income levels. This demonstrates that the trade areas have higher than average income levels which is our main customer characteristic. 


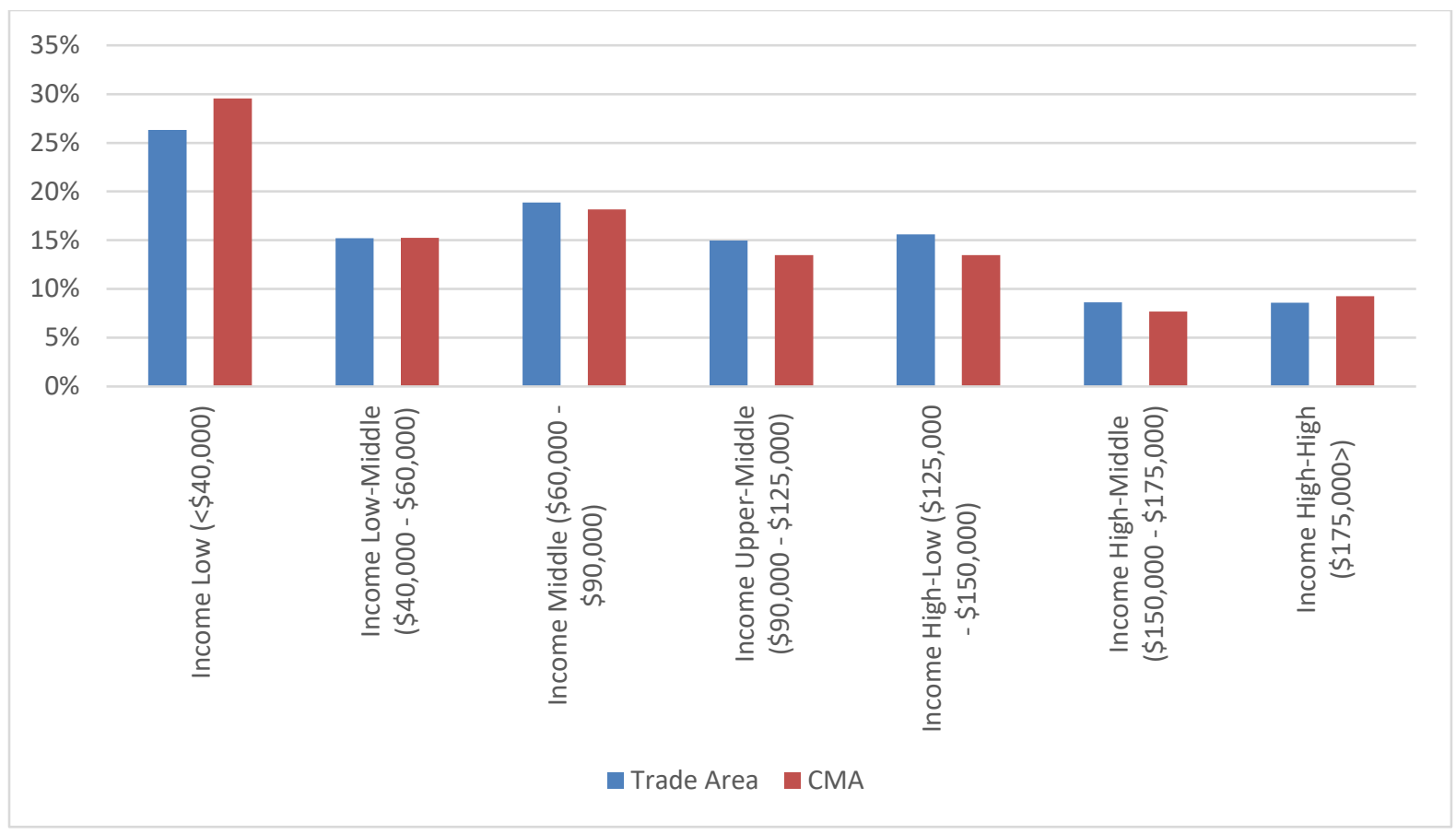

Figure 4.5: Income level distribution at the aggregate trade area and CMA level.

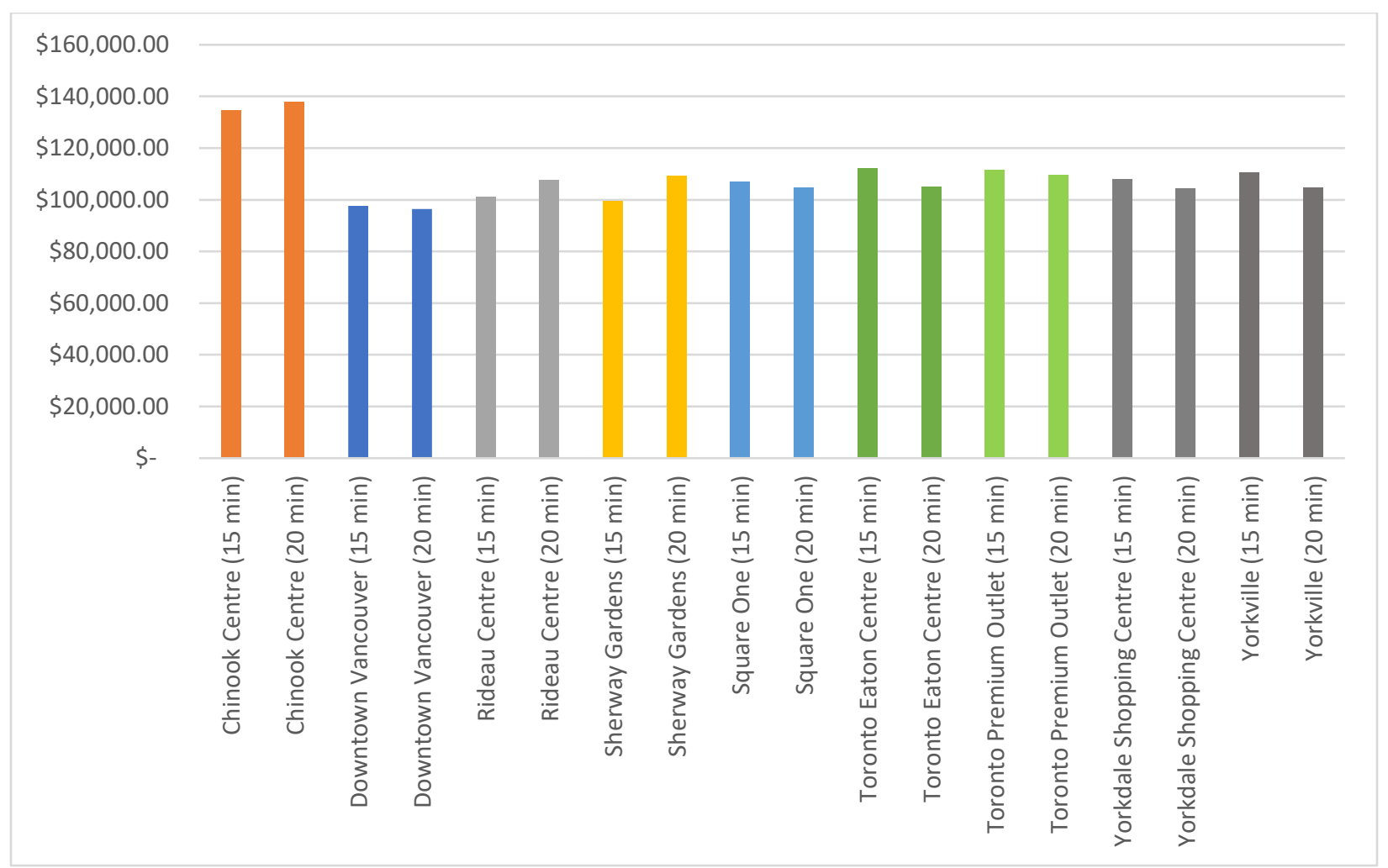

Figure 4.6: Average household income for each of the drive time trade areas 


\subsubsection{Industry and Occupation}

The top industries are professional, scientific and technical services (11\%), retail trade (10\%), health care and social assistance (9\%), manufacturing (8\%), finance and insurance (7\%), and educational services (7\%), as seen in Figure 4.7. When compared to the CMA, the trade area has significantly more people within the professional, scientific and technical services, and the finance and insurance, both of which are top industries in the trade area. The top occupations present are sales and service (24\%), business finance administration (18\%), social science, education, government, and religion (13\%), management $(11 \%)$, and sciences $(10 \%)$, as seen in Figure 4.8. The percentages for the occupation variables at the aggregate trade area level and the CMA level are very similar, no significant differences were found. The variables are broad and can describe a large range of jobs that range in educational requirements and income levels. Looking at the age, income, and educational variables in conjunction with these variables helps support the finding found within those sections. 


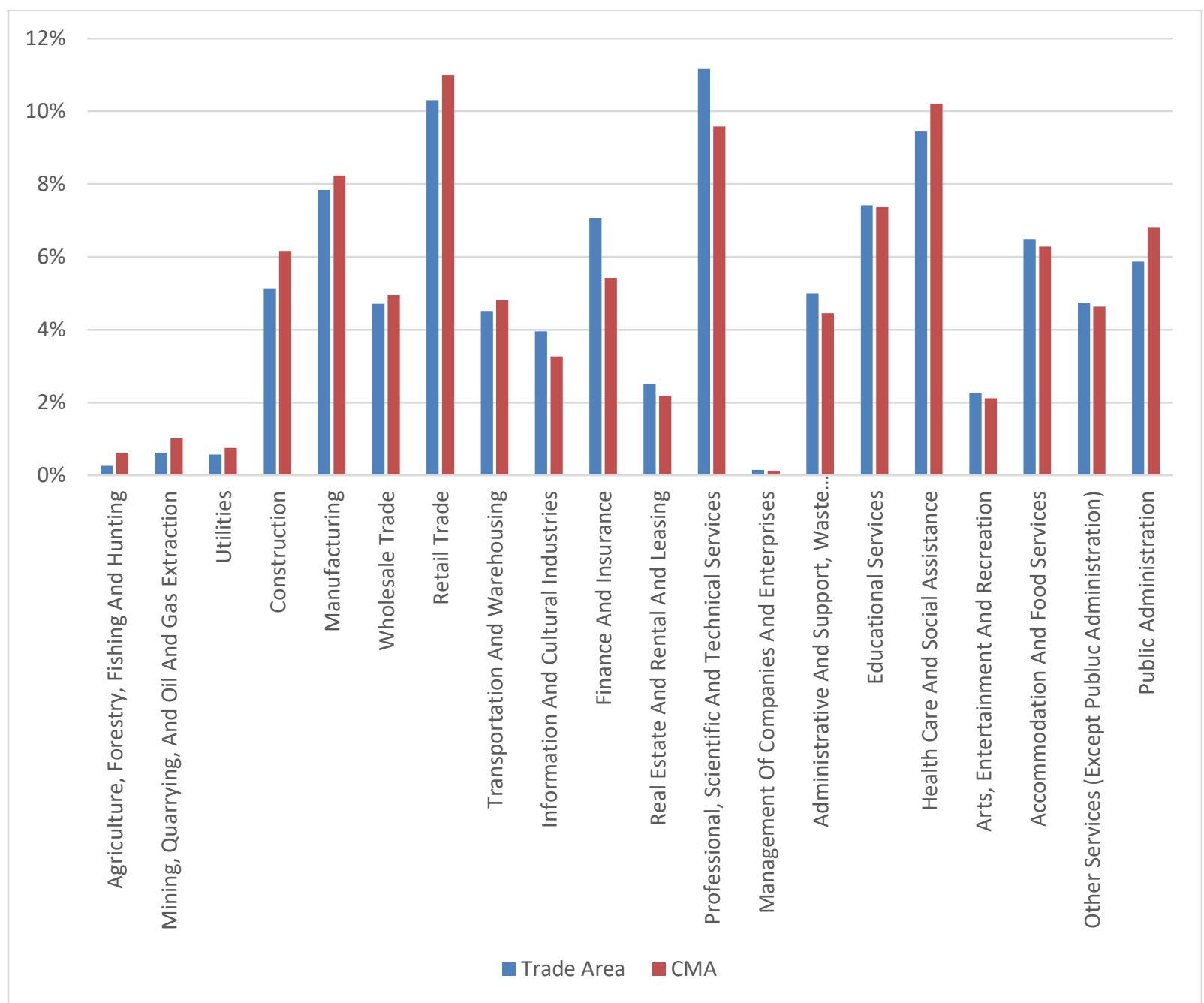

Figure 4.7: Industry distribution at the aggregate trade area and CMA level.

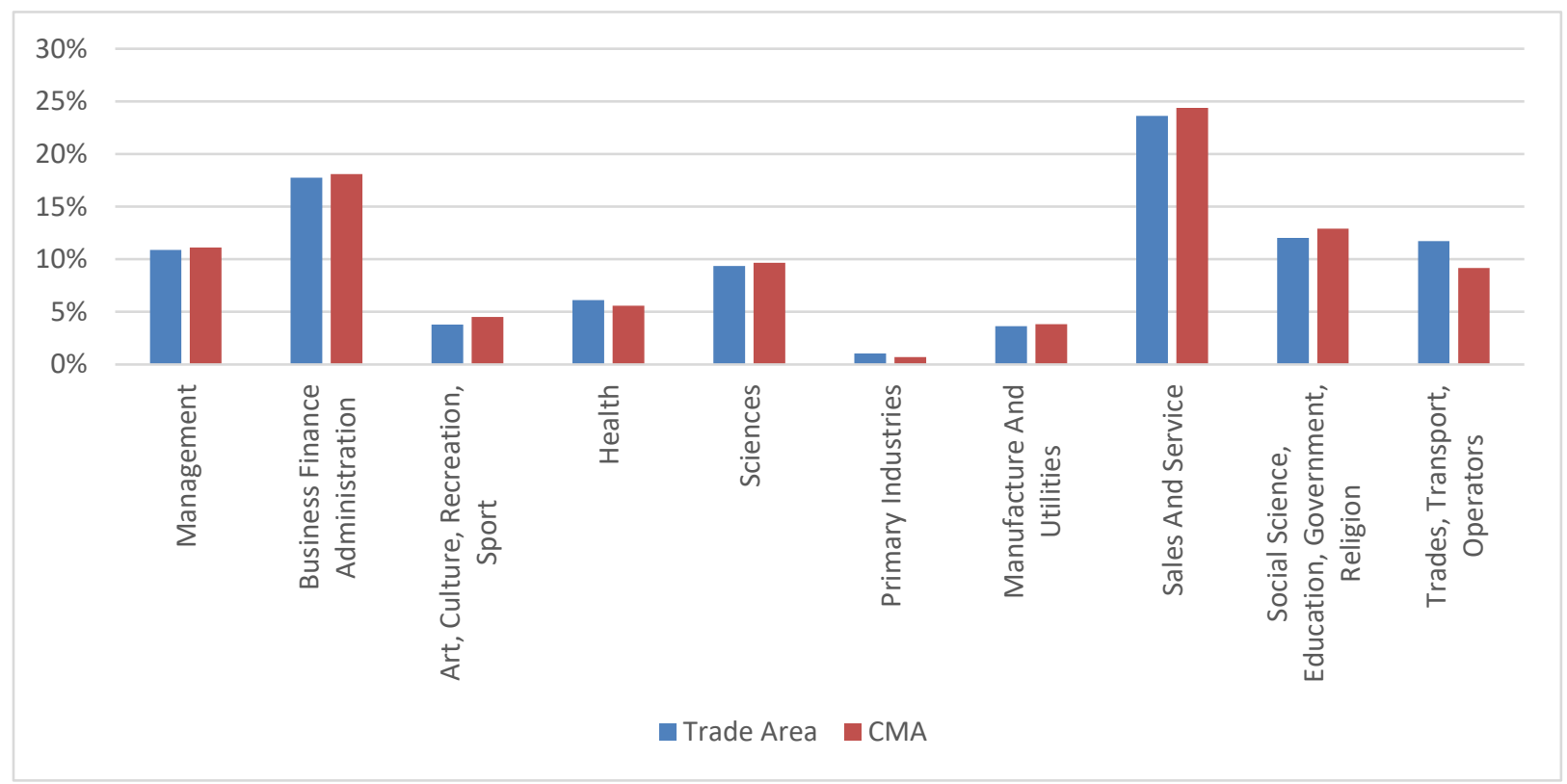

Figure 4.8: Occupation distribution at the aggregate trade area and CMA level. 


\subsubsection{Visible Minority}

A visible minority according to Statistics Canada is "persons, other than Aboriginal peoples, who are non-Caucasian in race or non-white in colour" (Statistics Canada, 2015). Nonvisible minorities are those who do not fall within the visible minority category, typically white or Caucasian people. There is a higher percentage of non-visible minorities (53\%) present within the trade areas than there are visible minority (43\%), as seen in Figure 4.9. At the CMA level, this difference is much greater, $64 \%$ of the total household population is not a visible minority compared to $36 \%$ visible minority. The aggregate trade areas level has a more equal distribution of visible minorities to non-visible minorities. This is the case at the individual trade area level except for the downtown Vancouver trade areas and the Toronto Premium Outlet trade areas. In these trade areas, the visible minority population is in the majority due to the large population of South Asian and Chinese visible minority populations. This instance of high population in the is South Asian and Chinese visible minority extents to the aggregate trade area results as seen in Figure 4.10. The most prevalent visible minorities are South Asian at $28 \%$ of the visible minority population followed by Chinese at $20 \%$. At the CMA level, the percentages are similar to those found at the aggregate trade area level. Only the South Asian visible minority shows a significant higher percentage in the aggregate trade area level.

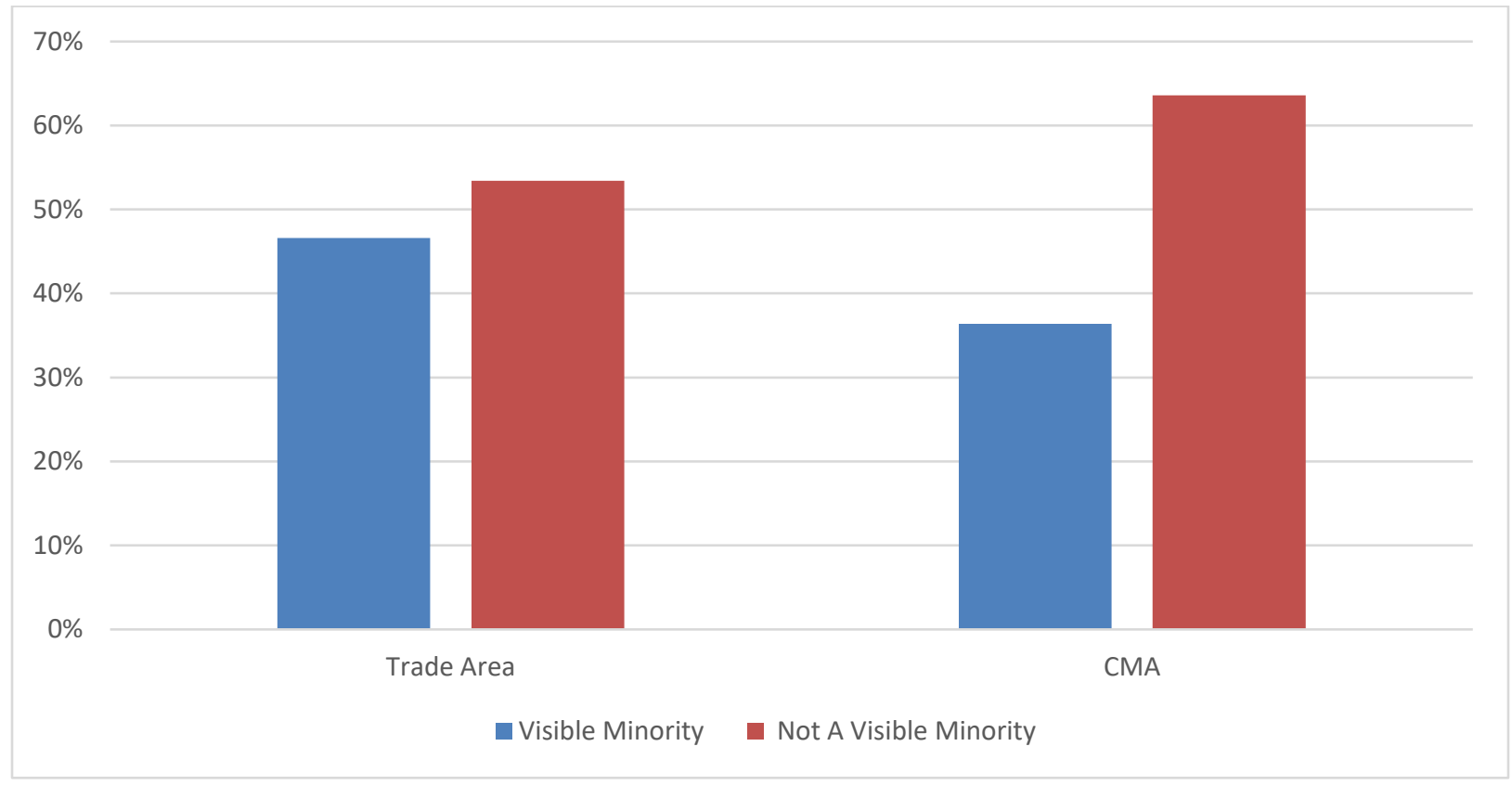

Figure 4.9: Visible minority verses non-visible minority at the aggregate trade area and CMA level. 


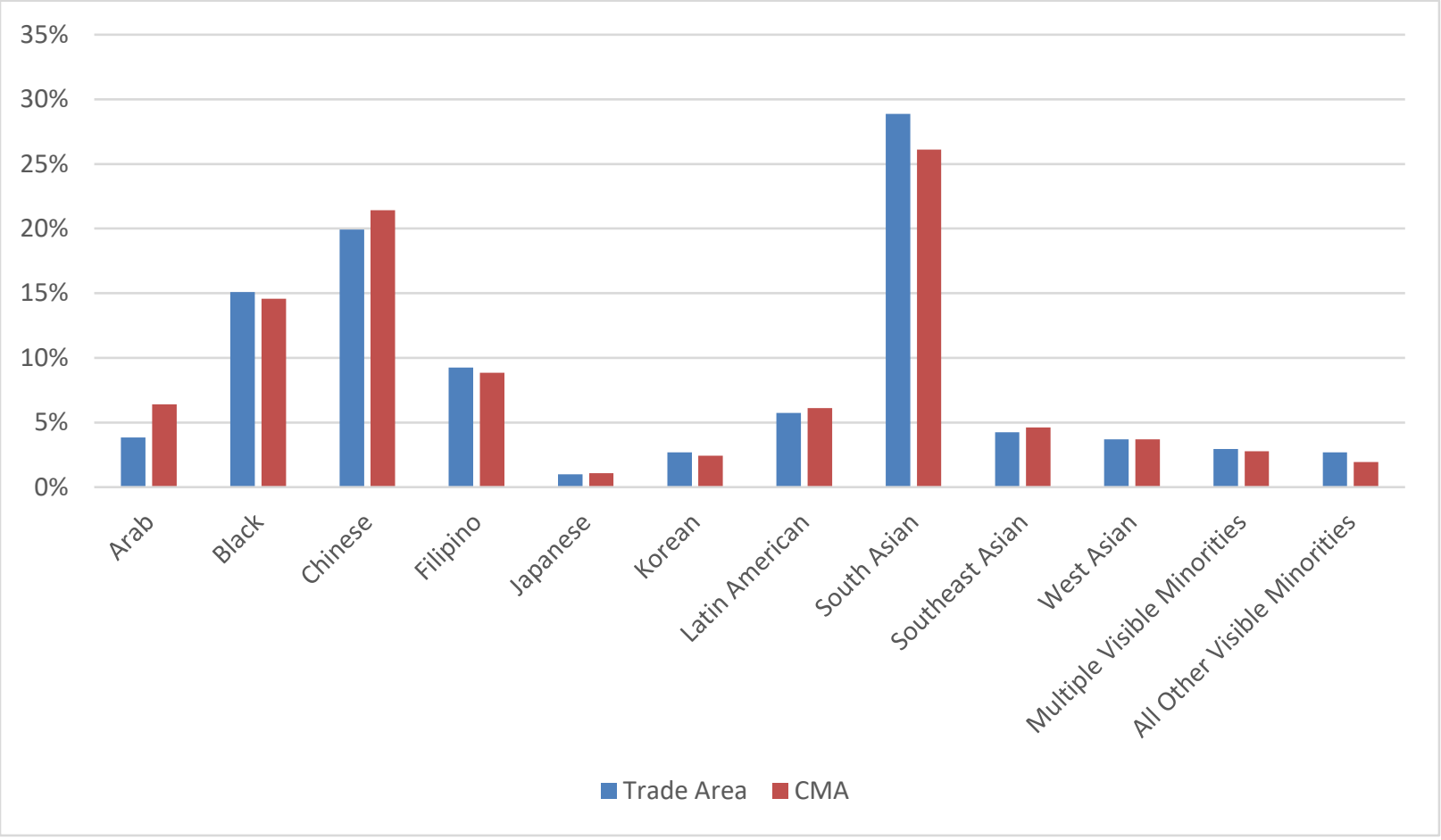

Figure 4.10: Visible minority distribution at the aggregate trade area and CMA level.

\subsubsection{Household Spending Habits}

The household operation and the income tax variables have the highest percentages at $25 \%$ and $27 \%$ respectively, as seen in Figure 4.11 . As a note, the household operation is based on current consumption whereas the income tax is based on disposable income. The high percentages found in these variables indicate a higher level of income amongst the households as the higher the income the higher the percentage is paid in taxes. The high percentage in shelter could be due to larger or multiple houses such as cottages or vacation homes, which would also point towards higher household incomes. The percentages for the household spending variables at the aggregate trade area level and the CMA level are very similar, no significant differences were found. 


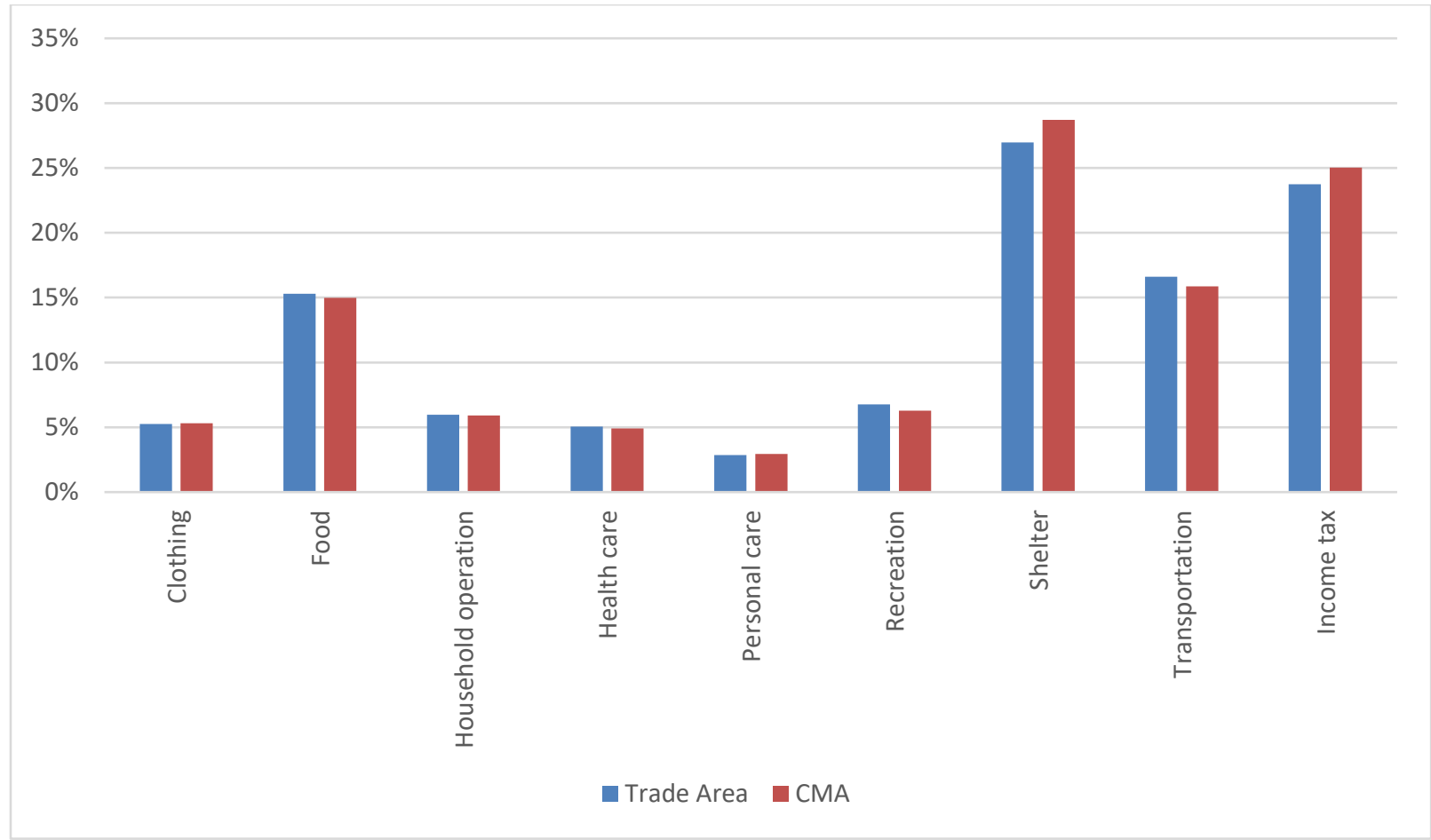

Figure 4.11: Household spending distribution at the aggregate trade area and CMA level.

\subsection{Choosing the Target Cluster}

For the study, we wanted to look for the cluster that best represented our target customer group. As mentioned previously, a certain level of income is needed to purchase high-end goods, those in the lower income brackets cannot afford items from these high-end retailers as most of their money is spent on essential items. They have little disposable income when compared to those in the higher income brackets. The income levels present within the clusters will be the key variables to look at when determining the target cluster. To determine the target cluster from the four clusters identified earlier, the final cluster centre table from the $\mathrm{K}$ means output was used. The final cluster centre table shows the mean value for each variable across all clusters. A high positive value represents that the variable has higher than average values for that variable in that cluster, and vise versa for the high negative values. The target cluster will have high values in the higher income brackets and lower values in the lower income brackets. The other variables will play a role as well, the target variable will be chosen based on the ideal combination of high and low values found within the variables. The results of the final cluster table were exported from SPSS and formatted to highlight the variable patterns 
found within each of the variable groups. Table 4.1 and 4.2 display the final cluster centre

values with conditional formatting applied to highlight the high and low values. A high value will

be red while a low value will be blue.

Table 4.1: Final cluster centres for all variables - part 1.

\begin{tabular}{|c|c|c|c|c|}
\hline \multirow{2}{*}{ Variable } & \multicolumn{4}{|c|}{ Cluster } \\
\hline & 1 & 2 & 3 & 4 \\
\hline \multicolumn{5}{|c|}{ Education } \\
\hline No certificate, diploma or degree & .77 & -.56 & -.70 & -.14 \\
\hline High school certificate or equivalent & .42 & -.92 & -.34 & .36 \\
\hline Apprenticeship or trades certificate or diploma & .41 & -.48 & -.54 & .18 \\
\hline $\begin{array}{l}\text { College, CEGEP or other non-university certificate } \\
\text { or diploma }\end{array}$ & -.07 & -.43 & -.11 & .58 \\
\hline University certificate or diploma below bachelor & -.15 & -.02 & .11 & .05 \\
\hline University degree & -.68 & .95 & .71 & -.28 \\
\hline Bachelor's degree & -.69 & .85 & .64 & -.18 \\
\hline Above Bachelor's & -.58 & .92 & .69 & -.36 \\
\hline \multicolumn{5}{|c|}{ Income } \\
\hline Average Household Income & -.55411 & -.46174 & .95959 & .20057 \\
\hline Income Low $(<\$ 40,000)$ & .59400 & .96167 & -.69147 & -.83114 \\
\hline Income Low-Middle $(\$ 40,000-\$ 60,000)$ & .74128 & .46582 & -.88657 & -.55652 \\
\hline Income Middle $(\$ 60,000-\$ 90,000)$ & 28920 & -.35689 & -.57882 & .37624 \\
\hline Income Upper-Middle $(\$ 90,000-\$ 125,000)$ & -.36936 & -.78352 & .09520 & .97153 \\
\hline Income High-Low $(\$ 125,000-\$ 150,000)$ & -.50207 & -.84060 & .32933 & .95512 \\
\hline Income High-Middle $(\$ 150,000-\$ 175,000)$ & -.66833 & -.67463 & .86460 & .60980 \\
\hline Income High-High $(\$ 175,000>)$ & -.60509 & -.37833 & 1.10332 & .05171 \\
\hline \multicolumn{5}{|c|}{ Marital Status } \\
\hline Married Or Living With A Common-Law Partner & -.34826 & -1.24058 & .60347 & .80191 \\
\hline $\begin{array}{l}\text { Not Married And Not Living With A Common-Law } \\
\text { Partner }\end{array}$ & .52273 & .05137 & -.32961 & -.66357 \\
\hline Single (Never Legally Married) & .05258 & 1.53396 & -.51963 & -.52274 \\
\hline \multicolumn{5}{|c|}{ Occupation } \\
\hline Management & -.59870 & -.14923 & .87213 & .17503 \\
\hline Business Finance Administration & -.11970 & -.07744 & .29624 & .04574 \\
\hline Art, Culture, Recreation, Sport & -.32122 & 1.18495 & .09594 & -.40754 \\
\hline Health & -.09899 & -.12104 & .31683 & -.07804 \\
\hline Sciences & -.43054 & .44733 & .39661 & .01322 \\
\hline Primary Industries & -.06459 & -.13547 & -.05793 & -.00961 \\
\hline Manufacture And Utilities & .48523 & -.46699 & -.54756 & .04290 \\
\hline Sales And Service & .66742 & -.12623 & -.60512 & -.26078 \\
\hline Social Science, Education, Government, Religion & -.44616 & .75863 & .48020 & -.23591 \\
\hline Trades, Transport, Operators & .39968 & -.77069 & -.57238 & .48640 \\
\hline \multicolumn{5}{|c|}{ Visible Minority } \\
\hline Chinese & -.24401 & .12513 & .53113 & -.24871 \\
\hline South Asian & -.12194 & -.41706 & -.02681 & .48196 \\
\hline Black & .32242 & -.00614 & -.37769 & -.10722 \\
\hline Filipino & -.00331 & -.26748 & -.05722 & .23872 \\
\hline Latin American & .20848 & 27257 & -.37226 & -.11500 \\
\hline Southeast Asian & .09498 & .12336 & -.24813 & .03022 \\
\hline Arab & .18408 & .14386 & -20323 & -.16915 \\
\hline West Asian & -.14706 & .11474 & .29695 & -.15123 \\
\hline Korean & -.33041 & 19679 & .44216 & -.06819 \\
\hline Japanese & -.26149 & 25188 & .31328 & -.07814 \\
\hline Not A Visible Minority & -.19943 & .04784 & .27228 & -.05455 \\
\hline
\end{tabular}


Table 4.2: Final cluster centres for all variables - part 2.

\begin{tabular}{|c|c|c|c|c|}
\hline & \multicolumn{4}{|c|}{ Cluster } \\
\hline & 1 & 2 & 3 & 4 \\
\hline \multicolumn{5}{|c|}{ Population Female } \\
\hline Females 15 To 19 & -.15360 & -1.26709 & .38675 & .70124 \\
\hline Females 20 To 24 & -.12005 & .60123 & -.06502 & -.07185 \\
\hline Females 25 To 29 & -.10881 & 1.44785 & -.49763 & -.30420 \\
\hline Females 30 To 34 & -.12298 & 1.68722 & -.73889 & -.10004 \\
\hline Females 35 To 39 & -.18027 & 1.13597 & -.71550 & .26125 \\
\hline Females 40 To 44 & -.32072 & .08269 & -.25007 & .74349 \\
\hline Females 45 To 49 & -.25292 & -.70781 & .29538 & .54011 \\
\hline Females 50 To 54 & -.07799 & -1.02943 & .60079 & .19037 \\
\hline Females 55 To 59 & .09951 & -.93005 & .72114 & -.26422 \\
\hline Females 60 To 64 & .12544 & -.62395 & .68695 & -.49935 \\
\hline Females 65 To 69 & .22873 & -.60299 & .72177 & -.67756 \\
\hline Females 70 To 74 & .34753 & -.49542 & .48895 & -.71285 \\
\hline Females 75 To 79 & .30410 & -.28500 & .18506 & -.58457 \\
\hline Females 80 To 84 & .28531 & -.17701 & .11044 & -.54173 \\
\hline Females 85 Or Older & .24646 & -.04064 & .12247 & -.53108 \\
\hline \multicolumn{5}{|c|}{ Population Male } \\
\hline Males 15 To 19 & -.09935 & -1.34856 & .42665 & .61331 \\
\hline Males 20 To 24 & -.05020 & .03641 & .14456 & -.03869 \\
\hline Males 25 To 29 & -.03979 & 1.55375 & -.48369 & -.40739 \\
\hline Males 30 To 34 & -.07571 & 1.49571 & -.64969 & -.19698 \\
\hline Males 35 To 39 & -.09853 & 1.39101 & -.79329 & .09223 \\
\hline Males 40 To 44 & -.20749 & .68394 & -.57570 & .53368 \\
\hline Males 45 To 49 & -.18266 & -.27058 & -.02418 & .53924 \\
\hline Males 50 To 54 & -.04946 & -.71189 & .37033 & .12527 \\
\hline Males 55 To 59 & .06645 & -.78597 & .66279 & -.24670 \\
\hline Males 60 To 64 & .05498 & -.62090 & .82377 & -.50004 \\
\hline Males 65 To 69 & .10725 & -.61036 & .82072 & -.61922 \\
\hline Males 70 To 74 & .14679 & -.48331 & .46985 & -.50350 \\
\hline Males 75 To 79 & .27228 & -.43923 & .35953 & -.57170 \\
\hline Males 80 To 84 & .26420 & -.32898 & .24522 & -.54133 \\
\hline Males 85 Or Older & 20710 & -.19834 & 21292 & -.48258 \\
\hline \multicolumn{5}{|c|}{ Household Spending } \\
\hline Shelter & -.03509 & .74595 & -.16396 & -.24449 \\
\hline Food & .50170 & .72765 & -.91266 & -.30565 \\
\hline Household operation & .06773 & -.70068 & .27997 & .05232 \\
\hline Health care & .57803 & -.18667 & -.00653 & -.75869 \\
\hline Transportation & -.13069 & -1.35983 & .27389 & .77871 \\
\hline Recreation & -.42795 & -.64023 & .65441 & .41244 \\
\hline Personal care & .23315 & .42467 & -.32094 & -.29933 \\
\hline Clothing & .04732 & .09459 & -.12578 & -.01086 \\
\hline Income tax & -.66061 & .19297 & .85016 & .01713 \\
\hline
\end{tabular}


From the final cluster table, two clusters meet the initial target cluster requirement of high income, clusters three and four. Cluster one and two both have high values in the lower income brackets thereby not meeting our target cluster requirements. When examining clusters three and four, cluster three has the higher values in the higher income levels and for the average household income. Looking at the other variables, cluster three shows variable values that are more in line with the target customers. They are highly educated, married, older mature adults aged $45-74$, and have occupations in management positions. Cluster four has similar characteristics but lacks significant high education and occupation is highest in the trades. Looking at the visible minority variables for cluster three, they are mainly Chinese with West Asian, Korean, Japanese and not visible minorities showing high values. For the Household Spending variables, the highest values are found in the income tax variable. High income tax can indicate higher income. The high value in the household operation supports the high value found in other variables as the household operation cost would increase the more expensive a house is. The other two high values, recreation and transportation show that the people within this cluster have active social lives as they enjoy and can spend their money on goods other than those that are essential such as food and shelter. Based on these characteristics, cluster three was chosen as the target cluster to represent our target customers.

\subsection{Choosing the Potential Sites}

To determine a potential site for the foreign high-end retailers to expand into, there needs to be a large amount of the target cluster grouped together. These locations already have some foreign high-end retailers in them, making it easier for new foreign high-end retailers to come in. Areas that have large groups of the target cluster but no locations with foreign high-end retailers also present an ideal potential spot. These areas have untapped customer potential, making it a new market for retailers to expand into. In these areas, a location needs to be chosen, shopping centres or the core downtown area will be the ideal candidate. The target

cluster (cluster 3) was mapped for each of the CMA's to determine the potential areas. To aid in the decision, the existing high-end clusters and all the remaining locations were also mapped. The existing high-end clusters will not be used as a candidate for potential new sites as they already are established high-end retailer locations. The remaining locations, as well as areas 
that are not on the list, will make up the candidate list. The income levels of the area play a role in determining the ideal location. By nature of the K-means clustering method, the census tracts that are the target cluster should have higher than average household income levels. The ideal location should have average household incomes within the top income brackets as generally the higher the income the more able the households are to afford the high-end items. A combination of the grouping of the target cluster and the higher household income levels will be the defining factor when deciding potential locations for the foreign high-end retailers to expand into.

\subsubsection{Calgary CMA}

In the Calgary CMA, there are two areas of interest, downtown Calgary and Southcentre Mall. Figure 4.12 displays the distribution of the target cluster in the Calgary CMA and Figure 4.13 displays the average household income levels in the Calgary CMA. The Core is located right in the heart of downtown Calgary, however it currently has only one foreign-high end retailer in it, Michael Kors. Holt Renfrew, a Canadian high-end department store, is located in The Core and has several foreign high-end brands located within it such as Gucci, Moncler, The Kooples, and Tiffany and Co. Some of these brands could place their own store within the mall outside of Holt Renfrew. The area surrounding the Core also has some potential for new locations. Just like in Yorkville or downtown Vancouver, streets in the downtown core have great potential for high-end brands. The income levels in the Calgary downtown core are in the middle to low income range, however, to the south towards Chinook Centre, is a large group of high income areas as seen in Figure 4.13. There is a group of the target cluster and higher average household income levels to the North-West of the downtown Calgary area. This area could provide some potential customers that currently likely travel far to the Chinook Centre shop for high-end brands. The Southcentre Mall is in the southern part of the Calgary CMA and is one of the largest shopping centres in Calgary. The mall also has only one foreign-high end retailer in it which happens to be Michael Kors again. The income levels in the immediate area of the Southcentre mall range from middle to high average household income levels. In similar fashion to downtown Calgary, the customers in this area most likely travel to the Chinook Centre to shop for high-end goods. By expanding into the Southcentre Mall, foreign high-end retailers 
could grab some of these customers as the location is closer to them. Both The Core and Southcentre Mall are shopping centres which means that they could develop a "Luxury Wing" just as other shopping centres in Canada have. The Southcentre Mall may have more of an opportunity to accomplish this as there is more space to expand whereas The Core is in downtown Calgary making expansion very limited. The expansion would have to come through existing shopping centre area or within the surrounding streets. The downtown area around The Core however could be more appealing to foreign high-end retailers as they have found success in other downtown cores of Canada like Vancouver and Toronto.

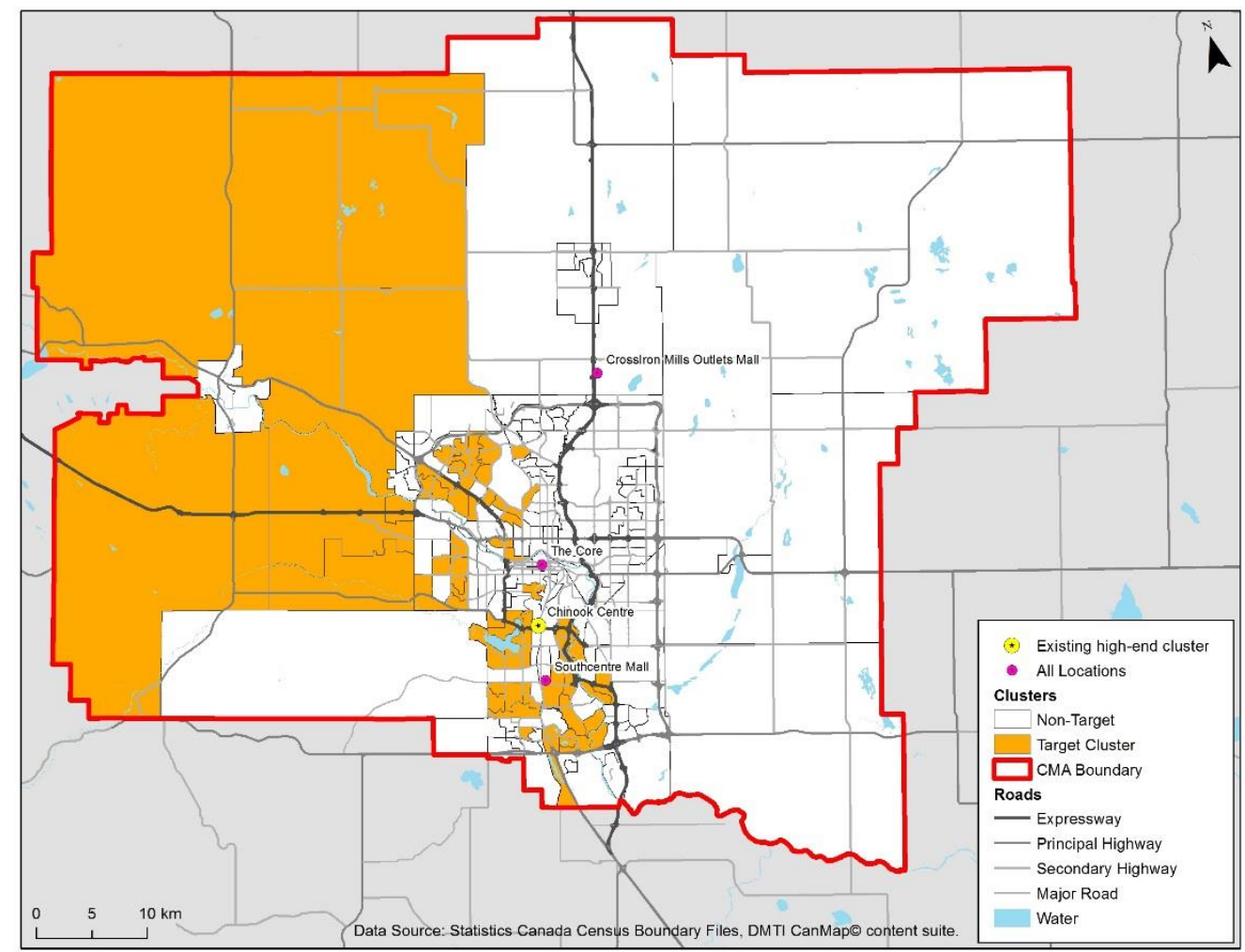

Figure 4.12: Target cluster in the Calgary CMA. 


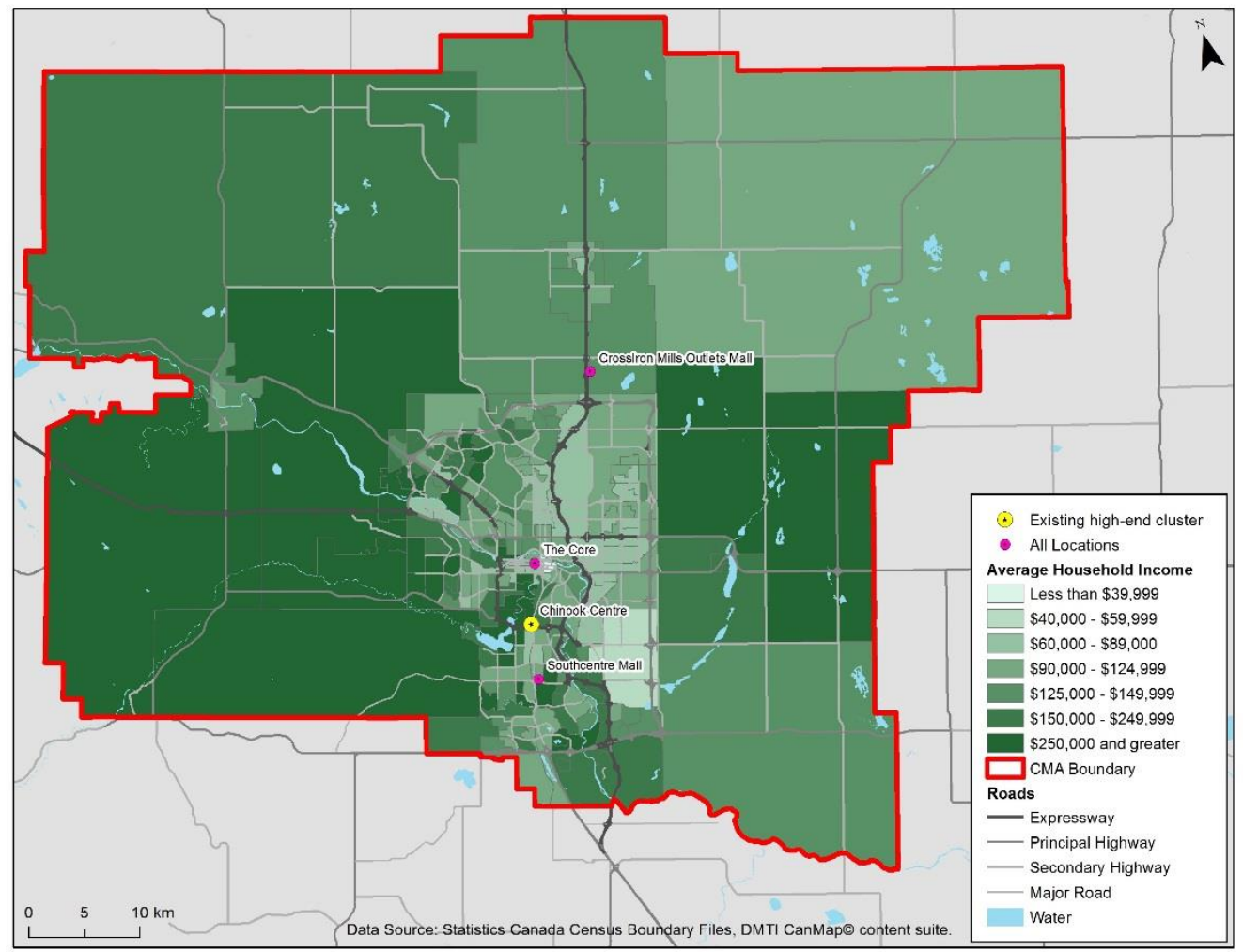

Figure 4.13: Average household income levels in the Calgary CMA.

\subsubsection{Edmonton CMA}

In the Edmonton CMA there is only one location that has a significant group of the target cluster, the West Edmonton Mall. Figure 4.14 displays the distribution of the target cluster in the Edmonton CMA and Figure 4.15 displays the average household income levels in the Edmonton CMA. The West Edmonton Mall is an ideal candidate as it already has established a "Luxury Wing" for high end retailers and already has eight foreign-high end retailers in it. The income levels to the south of the West Edmonton Mall are in the higher average household income levels. These potential customers most likely already use the West Edmonton Mall for their high-end shopping needs. The other two locations in the Edmonton CMA; Commerce Place and Southgate Centre, only have one and two foreign high-end retailers in them respectively. They have income levels in the low to middle average household income range. Expanding into the West Edmonton Mall would be the best choice within the Edmonton CMA as there are foreign high-end retailers present, a large group of the target cluster and potential customers with higher average household income levels. 


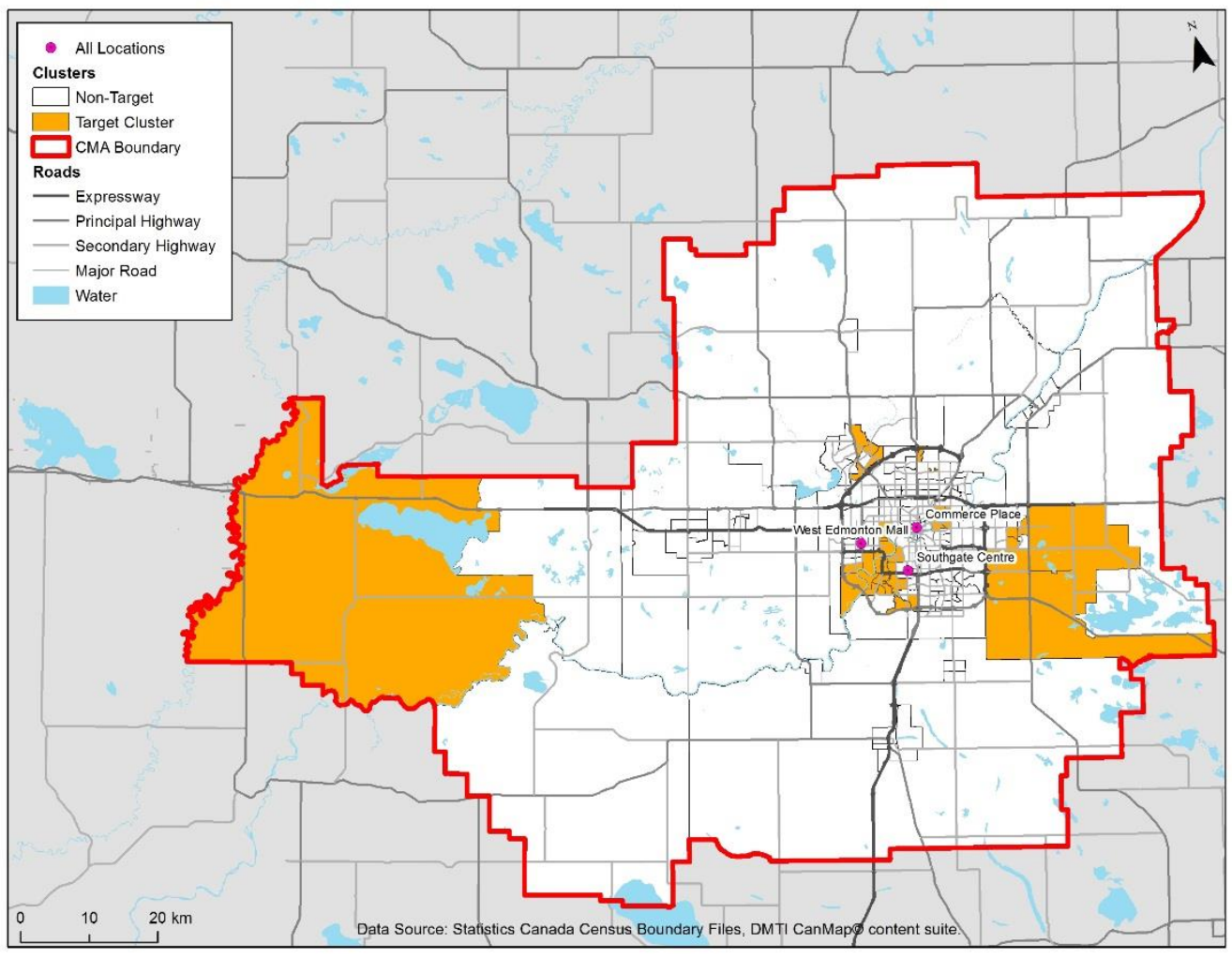

Figure 4.14: Target cluster in the Edmonton CMA.

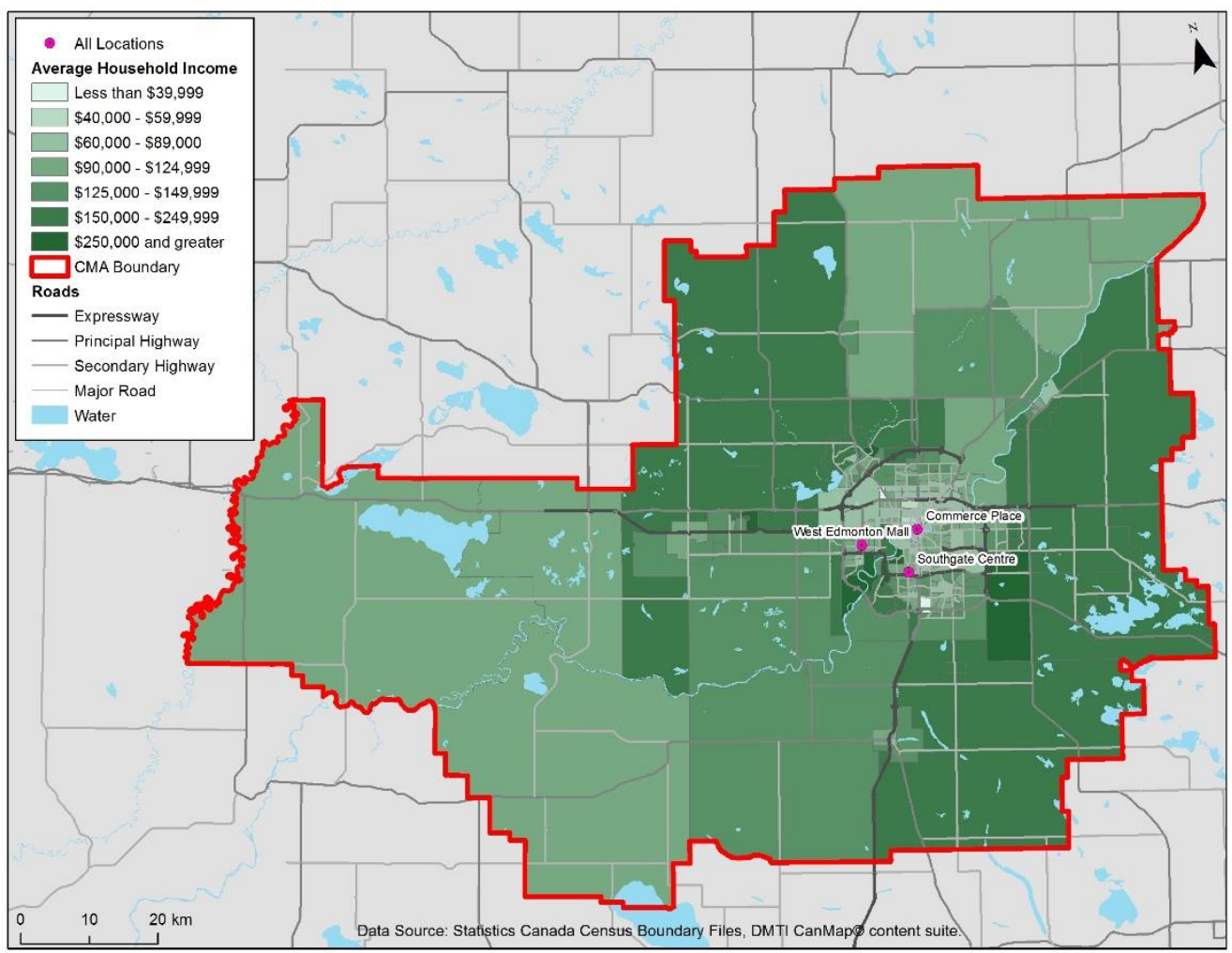

Figure 4.15: Average household income levels in the Edmonton CMA. 


\subsubsection{Montreal CMA}

In the Montreal CMA, there are three locations of interest: the downtown Montreal area, Fairview Point Claire, and Promenades St. Bruno. Figure 4.16 displays the distribution of the target cluster in the Montreal CMA and Figure 4.17 displays the average household income levels in the Montreal CMA. The downtown Montreal area has two locations that could be potential sites for expansion, downtown Montreal itself and the Rockland Centre. The Rockland Centre is a traditional shopping centre located just outside of the core downtown of Montreal and currently contains three foreign high-end retailers. The downtown Montreal area contains seven foreign high-end retailers within its collection of streets. Both locations could be expanded into equally as the target cluster is located between the two and since there is currently no existing high-end clusters present within the Montreal CMA, the downtown Montreal area like other downtown areas in Canada can become a prime location for new foreign high-end retailers. The other two locations Fairview Pointe Claire and Promenades St Bruno are both traditional shopping centres. Both have a large group of the target cluster near them making them ideal potential new locations. As for the income levels, Fairview Point Claire has higher income levels present when compared to Promenades St. Bruno. Expanding into these locations would most likely capture those customers who are traveling into the Montreal downtown core to shop for high-ends goods as both these locations currently have a small amount of foreign high-end retailers in them. 


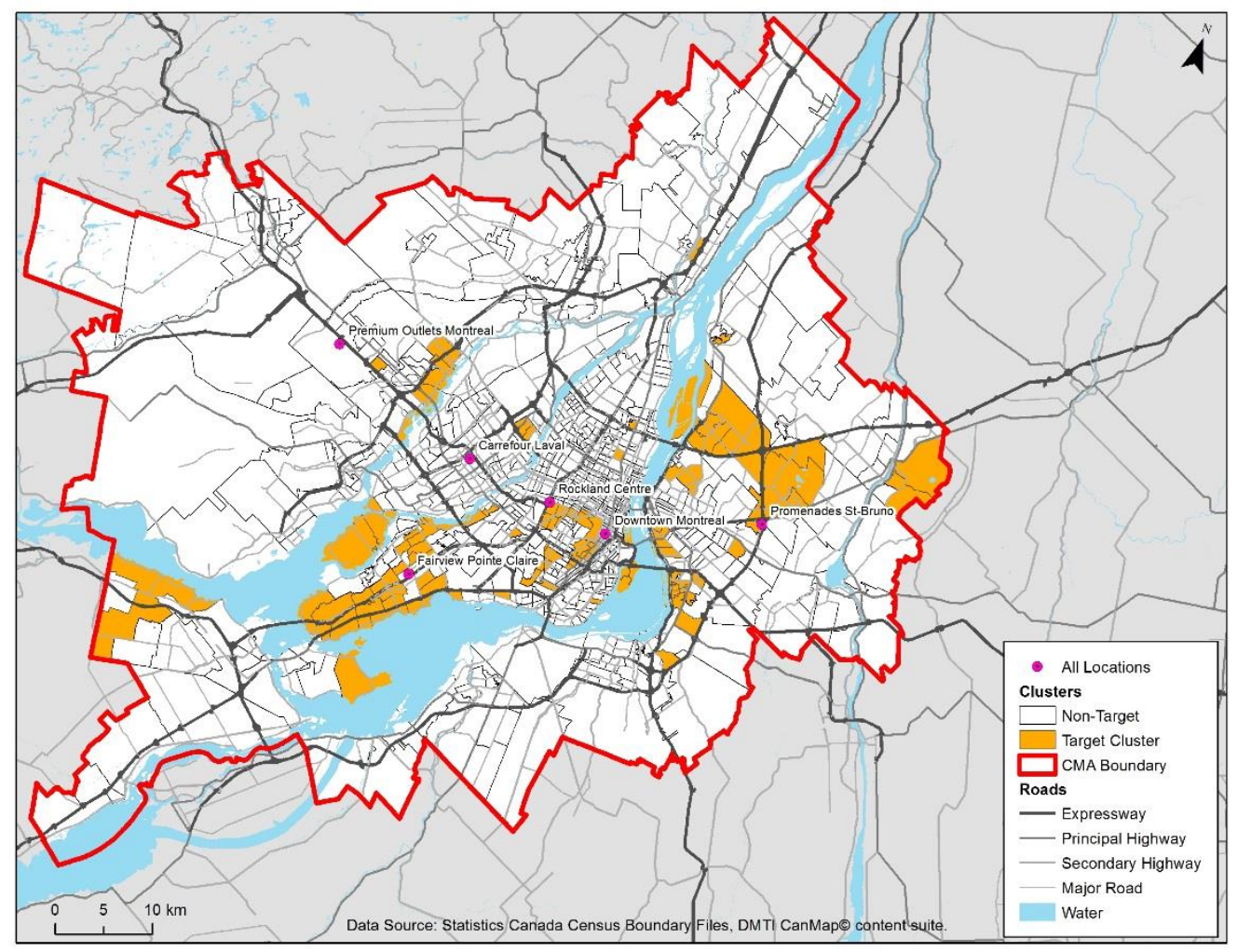

Figure 4.16: Target cluster in the Montreal CMA.

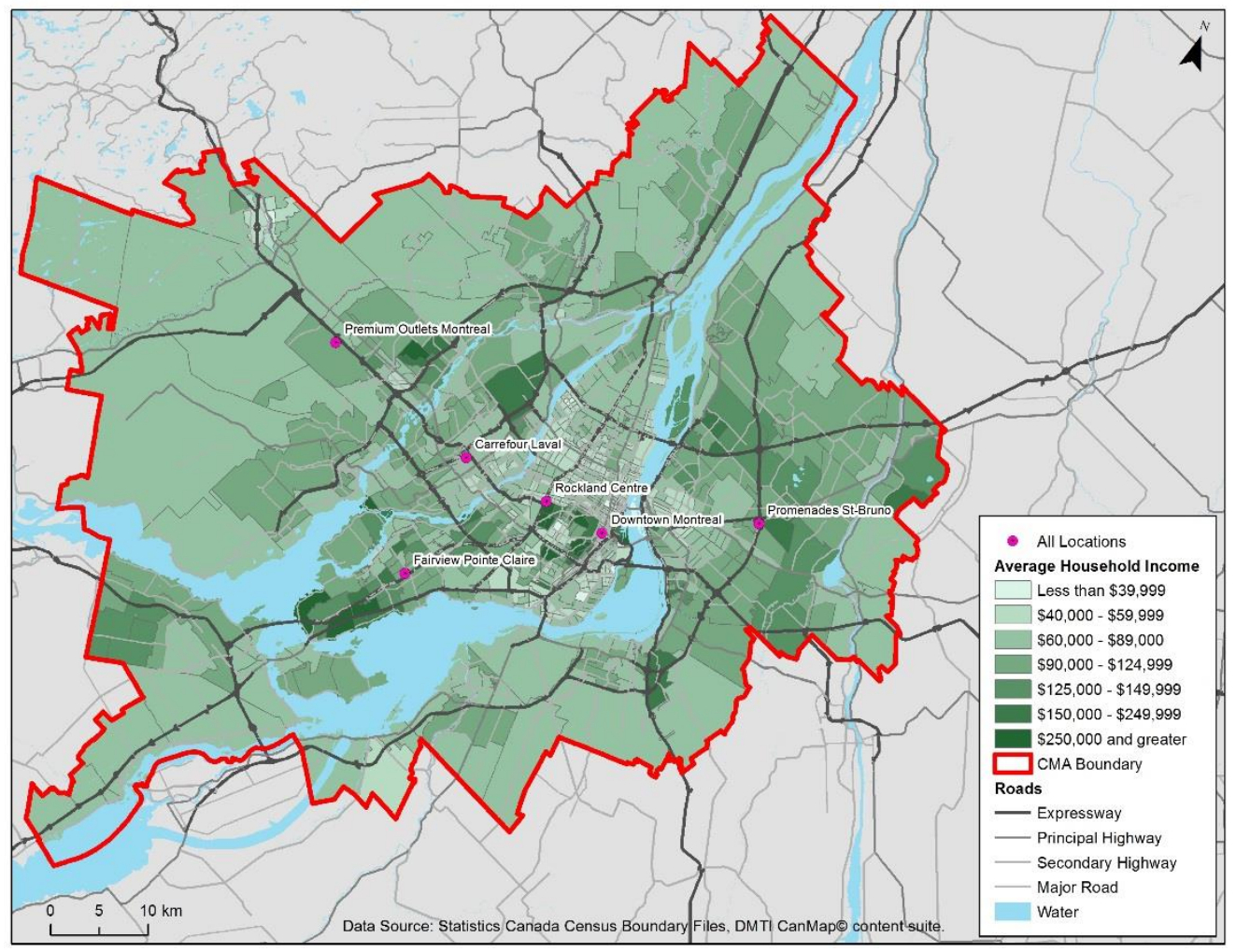

Figure 4.17: Average household income levels in Montreal CMA. 


\subsubsection{Ottawa CMA}

In the Ottawa CMA, there is only one potential location that has a significant group of the target cluster, Tanger Outlets Ottawa. Figure 4.18 displays the distribution of the target cluster in the Ottawa CMA and Figure 4.19 displays the average household income levels in the Ottawa CMA. The Tanger Outlets Ottawa currently only has two foreign high-end retailers in it, Coach and Michael Kors. The income levels present near Tanger Outlets Ottawa are within the mid to high average household income range. This location is like the Toronto Premium Outlet in Halton Hills, which is one of the existing high-end clusters in the Toronto CMA. Both are located outside of their respective downtown core and both are outlet shopping centres. The outlet locations can also pull in a wider range of customers as the prices are lower in outlet shopping centres. The major obstacle is the notion that some foreign high-end retailers may not want to "ruin" their brand by having a store within an outlet centre. As the Toronto Premium Outlet has shown, there is a lot of potential for high-end retailer within an outlet shopping centre.

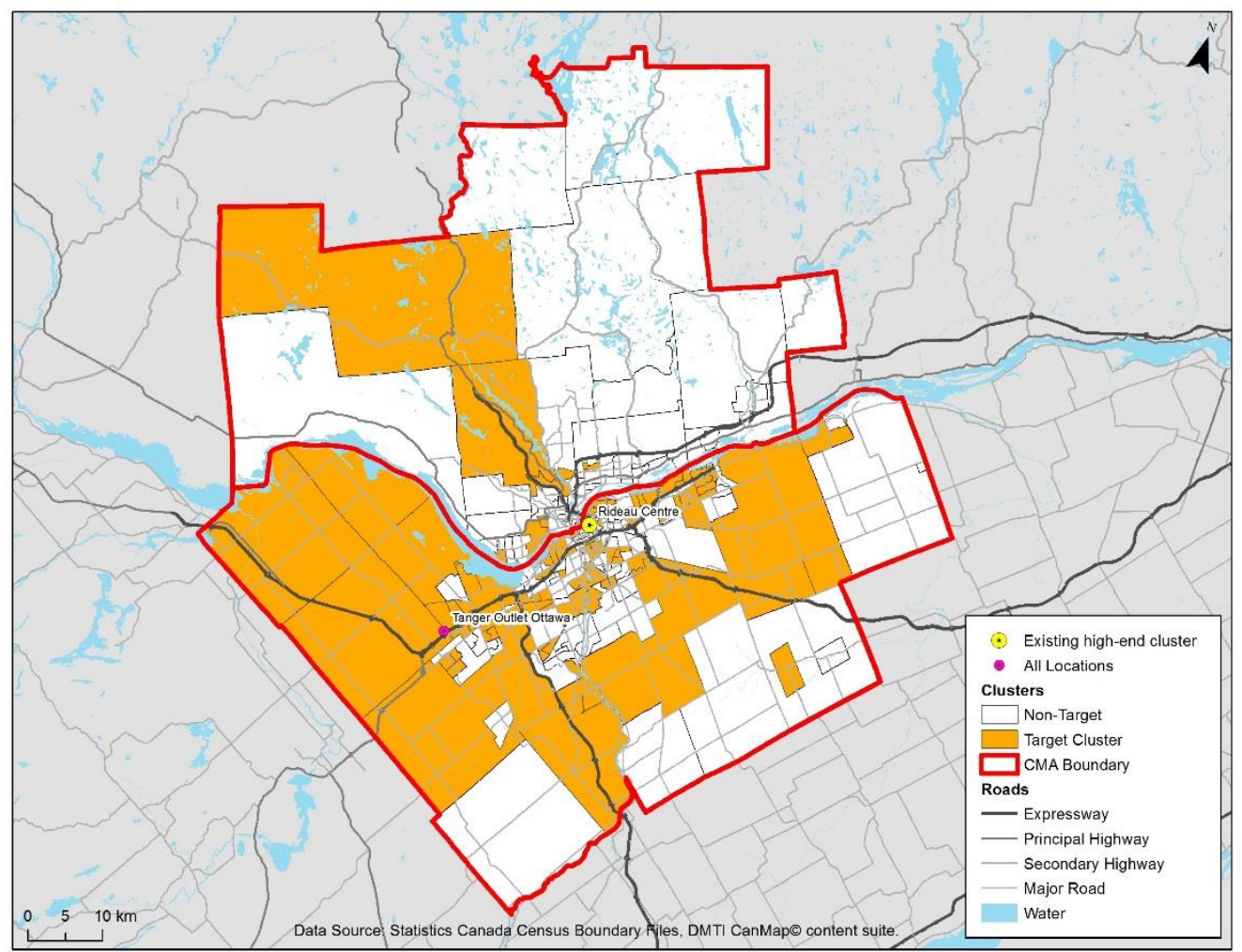

Figure 4.18: Target cluster in the Ottawa CMA. 


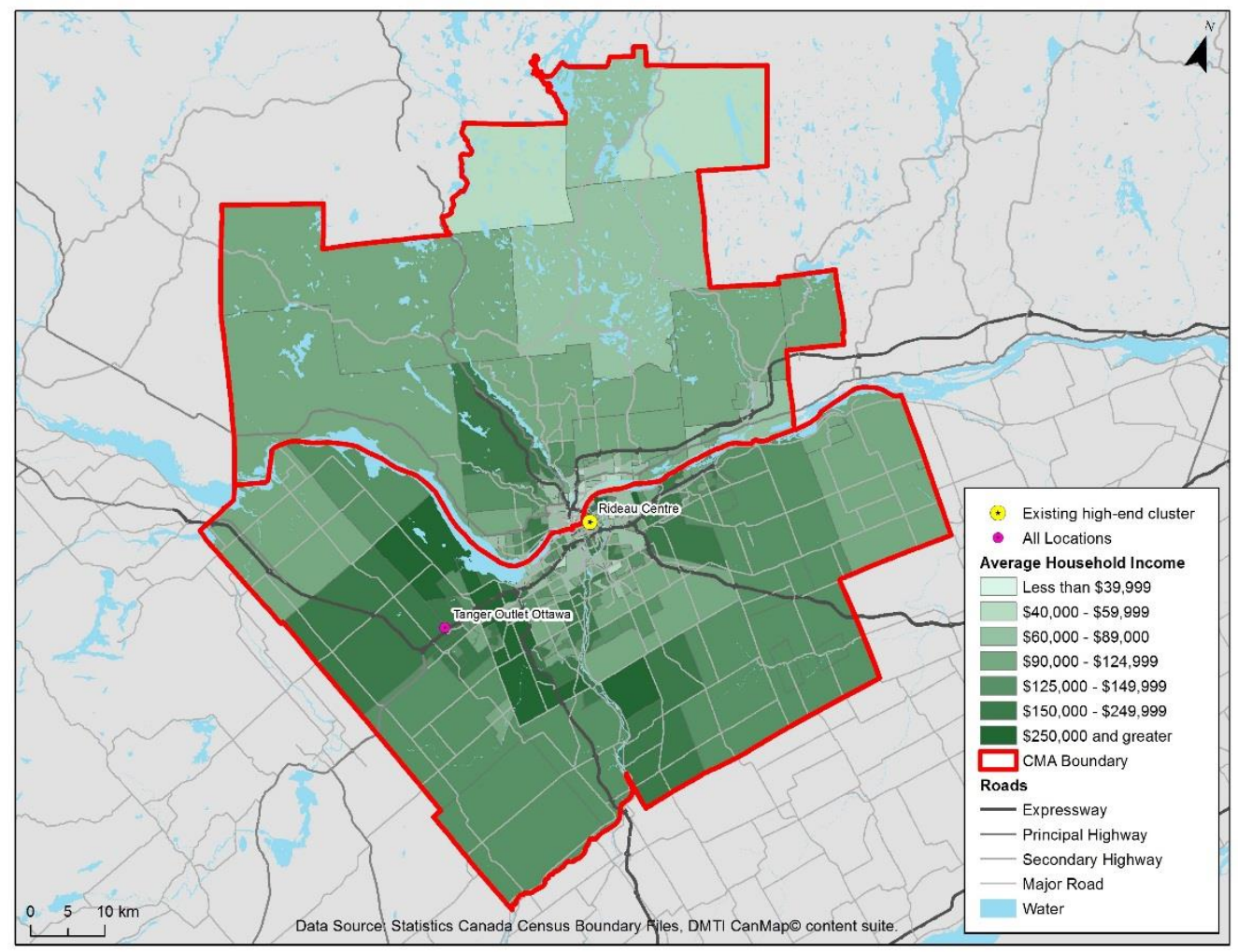

Figure 4.19: Average household income levels in the Ottawa CMA.

\subsubsection{Vancouver CMA}

Apart from the existing high-end clusters, there are three locations of interest within the Vancouver CMA: Richmond Centre, Oakridge Centre, and Park Royal Shopping Centre. Figure 4.20 displays the distribution of the target cluster in the Vancouver CMA and Figure 4.21 displays the average household income levels in the Vancouver CMA. All three of these locations already have some foreign high-end retailers in them, Richmond Centre has four, Oakridge Centre has five, and Park Royal Shopping Centre has three. All three of these locations have groups of the target cluster close to them, but differ on the average household income levels present. Richmond Centre has the lowest income levels of the three ranging from mid to low average household income. Oakridge Centre and Park Royal Shopping Centre average household income levels range from low to high. All three of these locations are traditional shopping centres making them the ideal retail type as well. 


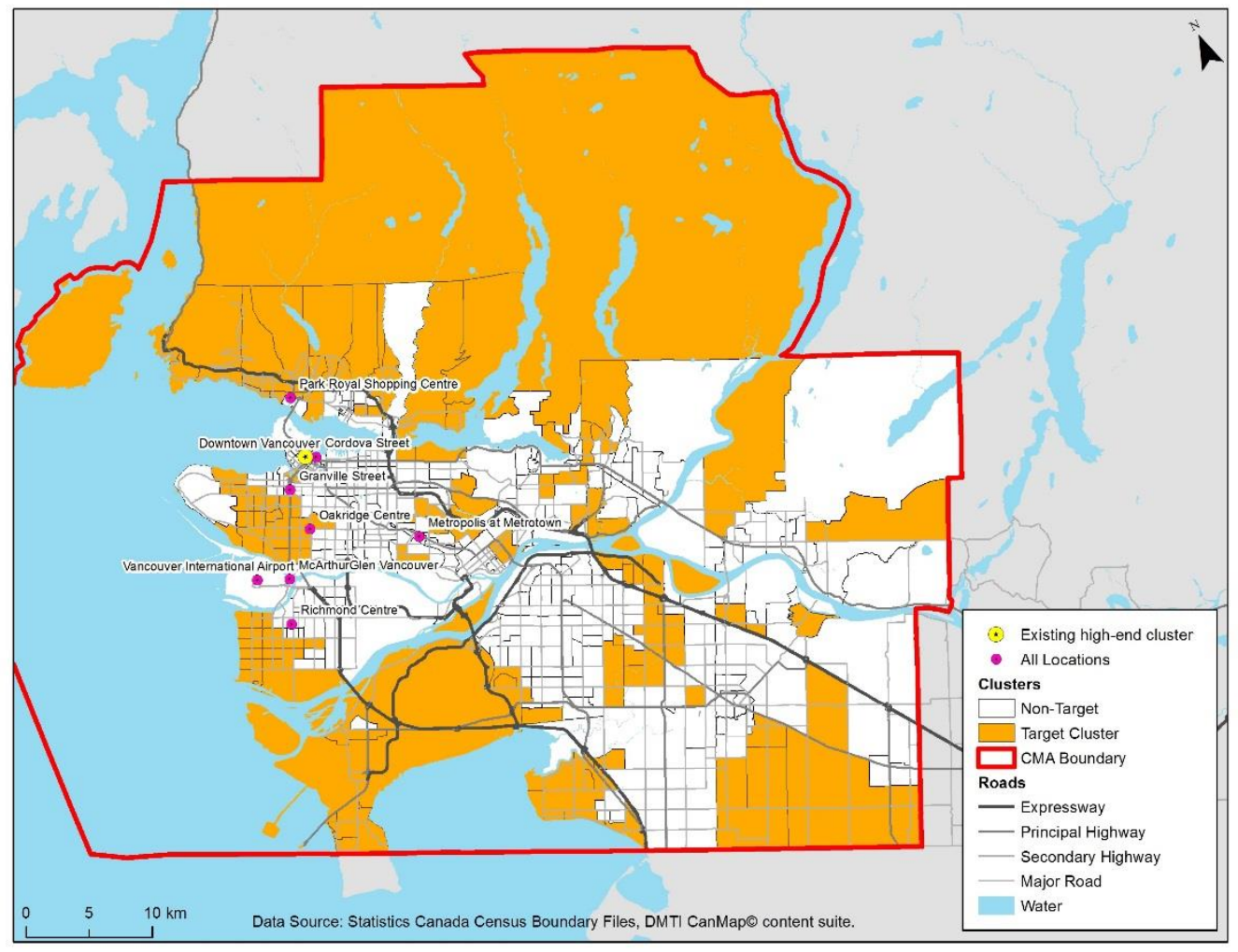

Figure 4.20: Target cluster in the Vancouver CMA.

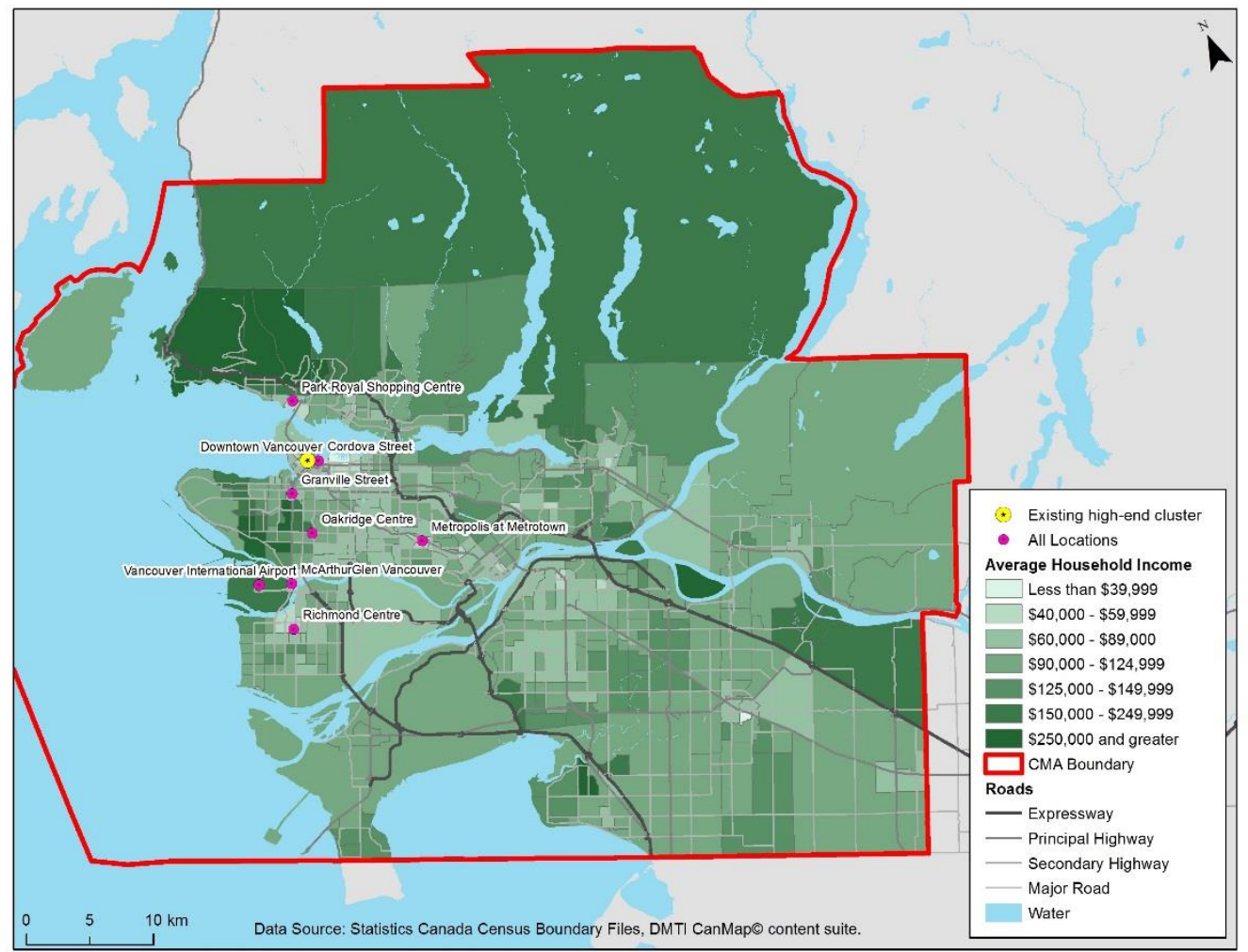

Figure 4.21: Average household income levels in Vancouver CMA. 


\subsubsection{Toronto CMA}

The Toronto CMA currently contains the highest amount of existing clusters with six of the nine in it. There is potential for other locations that foreign high-end retailers can expand into. Figure 4.22 displays the distribution of the target cluster in the Toronto CMA and Figure 4.23 displays the average household income levels in the Toronto CMA. Two areas are of interest: the eastern end of the Toronto CMA, and Oakville on the western edge. In the eastern end of the CMA, there are some groups of target clusters present especially around the Markville Shopping Centre. Looking at the average household income they range from mid to low in most areas with some groups of higher income levels towards the eastern border. The benefit of placing a location in the eastern end of the Toronto CMA is that it would take up the large gap seen in the Thiessen polygons map (Figure 3.2). The eastern end is entirely taken up by Yorkdale Shopping centre, by increasing the number of foreign high-end retailers in a location here, this large area can be redistributed more evenly. This would also capture those that live outside the CMA to the east as there are no other existing clusters between Toronto and Ottawa. As for the second location, the majority of Oakville is made up of the target cluster and there is currently no location present with foreign high-end retailers. The average household income is also in the mid to high-income levels for the majority of Oakville. There would be two candidates within Oakville that best suit foreign high-end retailers, one being Oakville Place located on 240 Leighland Ave, Oakville, ON just north of the Queen Elizabeth Way. The other location within Oakville would be the downtown area specifically along Lakeshore Road. This would be like Yorkdale or downtown Vancouver but in a suburban setting. 


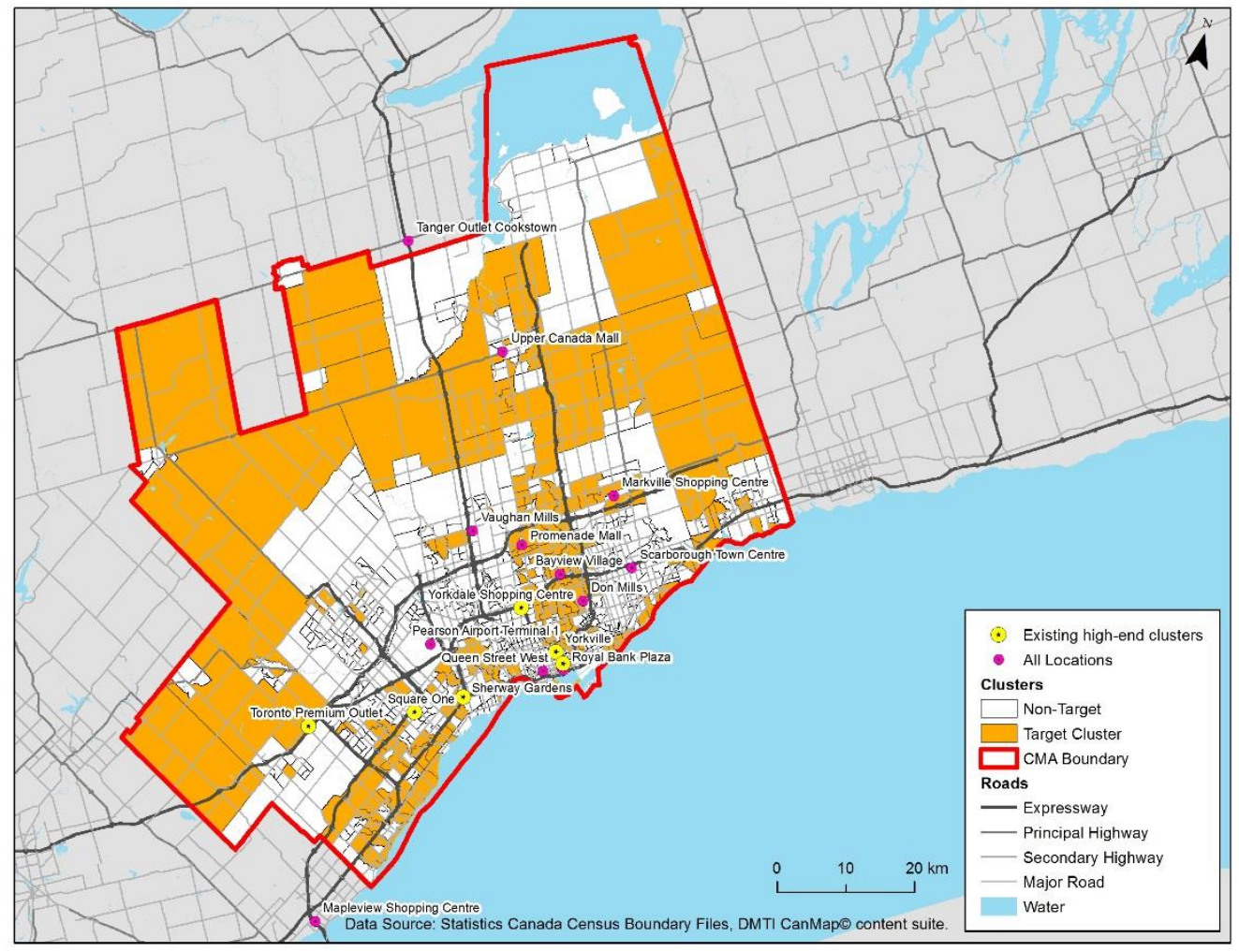

Figure 4.22: Target cluster in the Toronto CMA.

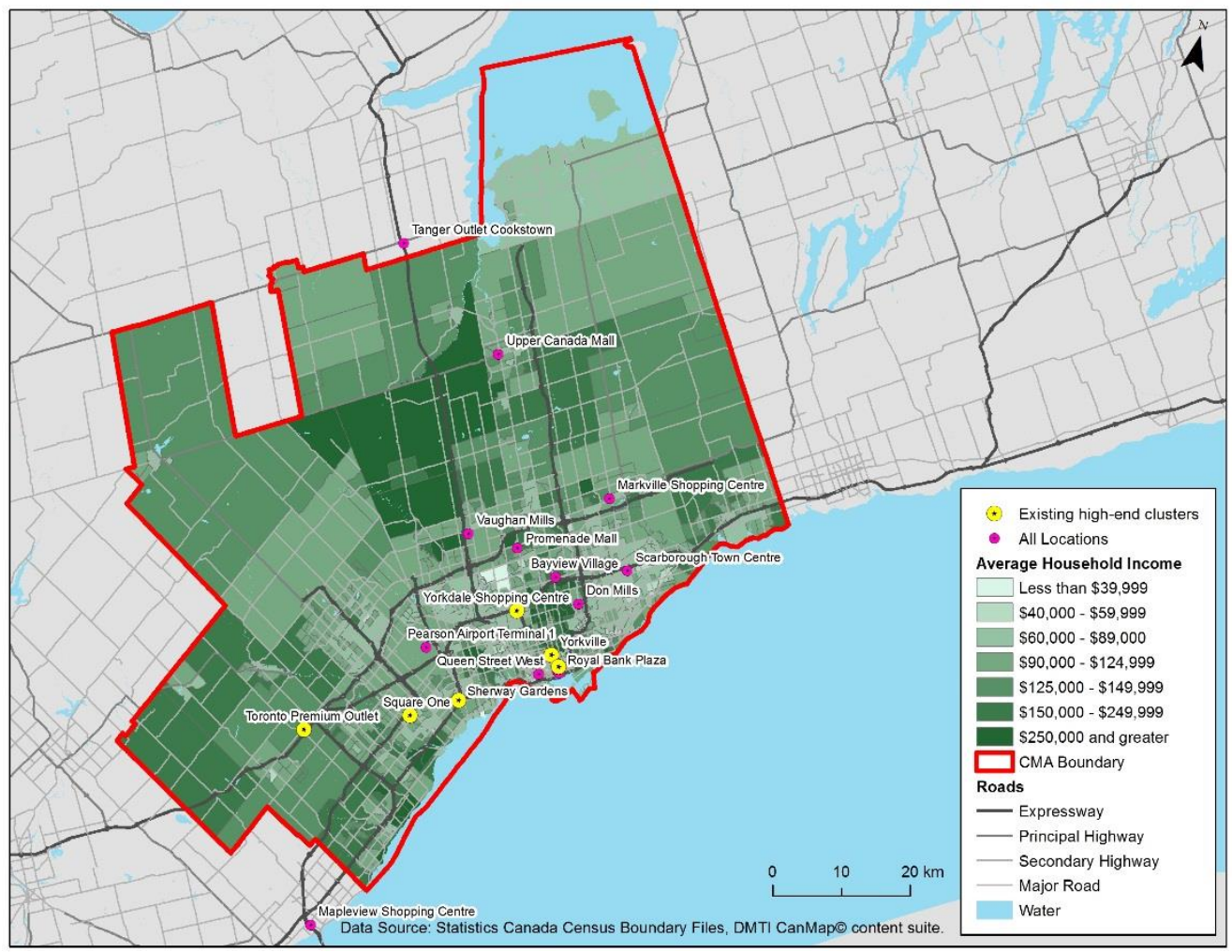

Figure 4.23: Average household income values for the Toronto CMA. 


\section{Chapter 5 - Discussion and Conclusion}

Determining the best locations in Canada for foreign high-end retailers to expand into was the main objective of this project. Existing clusters of foreign high-end retailers in the major CMA's of Canada were identified and these locations were used as the basis for determining what other locations would best suit expansion. The new potential locations would be based on the demographic, household spending habits, and locations of the existing highend clusters.

To determine potential customers for each of the existing clusters, drive time trade areas were created. A primary trade area of 15-min was used, and a secondary trade area of 20-min. The 15-min drive time was determined by Brunner \& Mason (1968) and further used by Cui (2012) as the ideal drive time that would contain the majority of the customers. The secondary trade area was created to include those customers who are willing to travel farther to shop for high-end goods. Using a combination of the two trade areas, the core potential customer base was determined. Toronto has the highest concentration of existing clusters of foreign high-end retailers. It is also the only CMA to have more than one existing foreign highend cluster location, six in total; three other CMAs (Calgary, Vancouver and Ottawa) have one existing cluster each. Toronto demonstrates that a sizeable CMA can have multiple locations with overlapping trade areas, and still be ideal for foreign high-end retailers. The identification of the retail type amongst the existing clusters demonstrated that shopping centres are the favoured location for foreign high-end retailers which followed the same conclusion that Emmons \& Hernandez (2016) found in their foreign retailers in Canada study. The downtown core locations (retail strips) like Yorkville and downtown Vancouver, and outlet shopping centres like Toronto Premium Outlet show that shopping centres are not the only viable potential location.

To narrow down the best locations within the CMA's the K-means clustering method was employed. The K-means clustering method allowed us to take a large amount of demographic and household spending data and condense them into four groups. Each of these four groups has their own demographic patterns and household spending habits. By selecting one of these clusters as the target group, the number of valid retail locations within each of the 
CMAs is reduced to those that have a significant group of the target cluster in close proximity. To help narrow down the locations even further, the average household income variable was employed as the key characteristic of the target cluster that was needed to be attractive to the high-end retailers.

Each CMA in the study contained potential locations. The Calgary CMA had two potential locations, The Core/downtown Calgary and Southcentre Mall, and one existing highend cluster location, Chinook Centre. Both potential locations currently have one foreign highend retailer, however they each have groups of the target cluster and high-income levels that are closer to them than the existing Chinook Centre cluster. The Edmonton CMA had only one potential location, the West Edmonton Mall and no existing high-end cluster locations. This location was on the cusp of being selected for the existing high-end cluster with eight high-end retailers in it, the minimum required was ten foreign high-end retailers. The high average household income levels and a large group of the target cluster made it the best potential location in the Edmonton CMA. The Montreal CMA had three potential locations, the downtown Montreal area, Fairview Point Claire, and Promenades St. Bruno and no current existing high-end cluster location. Each of these locations already has a few foreign high-end retailers, have their own group of the target cluster near them, and mid to high average household income levels. With no current existing high-end cluster location in Montreal, each of these locations shows great potential for the foreign high-end retailer to expand into. The Ottawa CMA has one potential location, Tanger Outlets and one existing cluster, Rideau Centre. This potential location was the only outlet shopping centre of all the potential locations identified in this study. Outlet shopping centres, like the existing Toronto Premium Outlet cluster, can pull in a wider range of customers due to the lower prices of items. By adding another location to the Ottawa CMA, which has several groups of the target cluster, the customers would have another location to shop at other than the Rideau Centre. The Vancouver CMA has three potential locations, Richmond Centre, Oakridge Centre, and Park Royal Shopping Centre and one current existing high-end cluster location, downtown Vancouver. Each of these potential locations already has a few foreign high-end retailers, have their own group of the target cluster near them, and mid to high average household income 
levels. The Toronto CMA has two areas of interest that could be viable even with the high instance of existing high-end clusters present in the CMA. The two areas of interest are; the eastern end of the Toronto CMA, and Oakville in the southern-western lake edge. The majority of Oakville is made up of the target cluster, however there is no location with foreign high-end retailers there. The eastern end of the CMA has retail locations with foreign high-end retailers in them but none are a part of the existing high-end clusters.

The results of the trade area demographics and the target cluster show that the income of the customer is the core variable that determines whether they are willing to shop at a highend retailer or not. The more retailers there are, the more options the customer has and the less of a need to travel to a more distant location. This is the case in the six CMA's in the study, each of them had areas of high average household income and/or groups of the target cluster but no nearby existing high-end retail cluster locations. Many of these potential customers have few or only one option in their own CMA to shop for high-goods all in one place. As foreign high-end goods are a specialized retail market, it is important that those who are part of that market can easily access stores and be satisfied with the number of high-end retail options available. By expanding into the potential sites identified in this study, especially in a CMA that currently does not have any existing high-end clusters, foreign high-end retailers will be able to incorporate more customers into their existing customer base. 
Table A1: Foreign high-end retailers store location information.

\begin{tabular}{|c|c|c|c|c|c|c|c|}
\hline Name & $\begin{array}{l}\text { Country } \\
\text { of Origin }\end{array}$ & Retail Location & CMA & Address & $\begin{array}{l}\text { Provin } \\
\text { ce }\end{array}$ & $\begin{array}{l}\text { Postal } \\
\text { Code }\end{array}$ & Retail Type \\
\hline All Saints & UK & Pacific Centre & Vancouver & $\begin{array}{l}701 \mathrm{~W} \\
\text { Georgia St, } \\
\text { Vancouver, } \\
\text { BC }\end{array}$ & $\mathrm{BC}$ & $\begin{array}{l}\text { V7Y } \\
1 G 5\end{array}$ & Major Downtown Mall \\
\hline All Saints & UK & Rue de la Montagne & Montreal & $\begin{array}{l}2138 \text { Rue de } \\
\text { la Montagne, } \\
\text { Montréal, }\end{array}$ & QC & $\begin{array}{l}\mathrm{H} 3 \mathrm{G} \\
1 \mathrm{Z7}\end{array}$ & Strip Mall \\
\hline All Saints & UK & Toronto Eaton Centre & Toronto & $\begin{array}{l}220 \text { Yonge St, } \\
\text { Toronto, ON }\end{array}$ & ON & $\begin{array}{l}\text { M5B } \\
2 \mathrm{H} 1\end{array}$ & Major Downtown Mall \\
\hline All Saints & UK & Yorkdale Shopping Centre & Toronto & $\begin{array}{l}3401 \text { Dufferin } \\
\text { Street Unit } \\
217 \text {, Toronto, } \\
\text { ON }\end{array}$ & ON & $\begin{array}{l}\text { M6A } \\
\text { 2T9 }\end{array}$ & $\begin{array}{l}\text { Traditional Shopping } \\
\text { Center }\end{array}$ \\
\hline Ann Taylor & USA & Sherway Gardens & Toronto & $\begin{array}{l}25 \text { The West } \\
\text { Mall, } \\
\text { Etobicoke, } \\
\text { ON }\end{array}$ & ON & $\begin{array}{l}\text { M9C } \\
1 \mathrm{~B} 8\end{array}$ & $\begin{array}{l}\text { Traditional Shopping } \\
\text { Center }\end{array}$ \\
\hline Ann Taylor & USA & Square One & Toronto & $\begin{array}{l}100 \text { City } \\
\text { Centre Dr, } \\
\text { Mississauga, } \\
\text { ON }\end{array}$ & ON & $\begin{array}{l}\text { L5B } \\
2 C 9\end{array}$ & $\begin{array}{l}\text { Traditional Shopping } \\
\text { Center }\end{array}$ \\
\hline Ann Taylor & USA & Toronto Eaton Centre & Toronto & $\begin{array}{l}220 \text { Yonge St, } \\
\text { Toronto, ON }\end{array}$ & $\mathrm{ON}$ & $\begin{array}{l}\text { M5B } \\
2 \mathrm{H} 1\end{array}$ & Major Downtown Mall \\
\hline Ann Taylor & USA & Yorkdale Shopping Centre & Toronto & $\begin{array}{l}3401 \text { Dufferin } \\
\text { Street Unit } \\
217 \text {, Toronto, } \\
\text { ON }\end{array}$ & ON & $\begin{array}{l}\text { M6A } \\
\text { 2T9 }\end{array}$ & $\begin{array}{l}\text { Traditional Shopping } \\
\text { Center }\end{array}$ \\
\hline Armani & Italy & McArthurGlen Vancouver & Vancouver & $\begin{array}{l}7899 \\
\text { Templeton } \\
\text { Station Rd } \\
\text { \#1000, } \\
\text { Richmond, BC }\end{array}$ & $\mathrm{BC}$ & $\begin{array}{l}\text { V7B } \\
\text { OB7 }\end{array}$ & Outlet Mall \\
\hline
\end{tabular}




\begin{tabular}{|c|c|c|c|c|c|c|c|}
\hline Name & $\begin{array}{l}\text { Country } \\
\text { of Origin }\end{array}$ & Retail Location & CMA & Address & $\begin{array}{l}\text { Provin } \\
\text { ce }\end{array}$ & $\begin{array}{l}\text { Postal } \\
\text { Code }\end{array}$ & Retail Type \\
\hline Armani & Italy & Toronto Premium Outlet & Toronto & $\begin{array}{l}13850 \text { Steeles } \\
\text { Avenue W, } \\
\text { Halton Hills, } \\
\text { ON }\end{array}$ & ON & L7G 0J1 & Outlet Mall \\
\hline Brunello Cucinelli & Italy & Thurlow Street & & $\begin{array}{l}747 \text { Thurlow } \\
\text { St, } \\
\text { Vancouver, } \\
\text { BC }\end{array}$ & $\mathrm{BC}$ & $\begin{array}{l}\text { V6E } \\
1 \mathrm{~V} 8\end{array}$ & Strip Mall \\
\hline Bulgari & Italy & $\begin{array}{l}\text { Pearson Airport Terminal } \\
1\end{array}$ & Toronto & $\begin{array}{l}5675 \text { Silver } \\
\text { Dart Dr, } \\
\text { Mississauga, } \\
\text { ON } \\
\end{array}$ & ON & $\begin{array}{l}\text { L5P } \\
1 B 2\end{array}$ & Airport \\
\hline Bulgari & Italy & $\begin{array}{l}\text { Vancouver International } \\
\text { Airport }\end{array}$ & Vancouver & $\begin{array}{l}3211 \text { Grant } \\
\text { McConachie } \\
\text { Way, } \\
\text { Richmond, BC }\end{array}$ & $\mathrm{BC}$ & $\begin{array}{l}\text { V7B } \\
\text { OA4 }\end{array}$ & Airport \\
\hline Bulgari & Italy & Yorkdale Shopping Centre & Toronto & $\begin{array}{l}3401 \text { Dufferin } \\
\text { Street Unit } \\
217 \text {, Toronto, } \\
\text { ON }\end{array}$ & ON & $\begin{array}{l}\text { M6A } \\
2 T 9\end{array}$ & $\begin{array}{l}\text { Traditional Shopping } \\
\text { Center }\end{array}$ \\
\hline Burberry & Italy & Alberni Street & Vancouver & $\begin{array}{l}1101 \text { Alberni } \\
\text { St, } \\
\text { Vancouver, } \\
\text { BC }\end{array}$ & $\mathrm{BC}$ & $\begin{array}{l}\text { V6E } \\
4 T 9\end{array}$ & Strip Mall \\
\hline Burberry & UK & Bloor Street & Toronto & $\begin{array}{l}\text { 131-151 Bloor } \\
\text { St W, } \\
\text { Toronto, ON }\end{array}$ & ON & $\begin{array}{l}\text { M5S } \\
1 \mathrm{P3}\end{array}$ & Strip Mall \\
\hline Burberry & UK & Chinook Centre & Calgary & $\begin{array}{l}6455 \\
\text { Macleod Trail } \\
\text { SW, Calgary, } \\
\text { AB }\end{array}$ & $A B$ & $\begin{array}{l}\mathrm{T} 2 \mathrm{H} \\
\text { OK8 }\end{array}$ & $\begin{array}{l}\text { Traditional Shopping } \\
\text { Center }\end{array}$ \\
\hline Burberry & UK & $\begin{array}{l}\text { Pearson Airport Terminal } \\
1\end{array}$ & Toronto & $\begin{array}{l}5675 \text { Silver } \\
\text { Dart Dr, } \\
\text { Mississauga, } \\
\text { ON } \\
\end{array}$ & ON & $\begin{array}{l}\text { L5P } \\
1 \mathrm{~B} 2\end{array}$ & Airport \\
\hline
\end{tabular}




\begin{tabular}{|c|c|c|c|c|c|c|c|}
\hline Name & $\begin{array}{l}\text { Country } \\
\text { of Origin }\end{array}$ & Retail Location & CMA & Address & $\begin{array}{l}\text { Provin } \\
\text { ce }\end{array}$ & $\begin{array}{l}\text { Postal } \\
\text { Code }\end{array}$ & Retail Type \\
\hline Burberry & UK & Shangri-La Hotel & Vancouver & $\begin{array}{l}1101 \text { Alberni } \\
\text { St, } \\
\text { Vancouver, } \\
\text { BC }\end{array}$ & $\mathrm{BC}$ & $\begin{array}{l}\text { V6E } \\
4 T 9\end{array}$ & Ancillary \\
\hline Burberry & UK & Toronto Premium Outlet & Toronto & $\begin{array}{l}13850 \text { Steeles } \\
\text { Avenue W, } \\
\text { Halton Hills, } \\
\text { ON }\end{array}$ & ON & L7G 0J1 & Outlet Mall \\
\hline Burberry & UK & $\begin{array}{l}\text { Vancouver International } \\
\text { Airport }\end{array}$ & Vancouver & $\begin{array}{l}3211 \text { Grant } \\
\text { McConachie } \\
\text { Way, } \\
\text { Richmond, BC }\end{array}$ & $\mathrm{BC}$ & $\begin{array}{l}\text { V7B } \\
\text { OA4 }\end{array}$ & Airport \\
\hline Burberry & UK & Yorkdale Shopping Centre & Toronto & $\begin{array}{l}3401 \text { Dufferin } \\
\text { Street Unit } \\
217 \text {, Toronto, } \\
\text { ON }\end{array}$ & ON & $\begin{array}{l}\text { M6A } \\
2 \mathrm{~T} 9\end{array}$ & $\begin{array}{l}\text { Traditional Shopping } \\
\text { Center }\end{array}$ \\
\hline Coach & USA & Bloor Street & Toronto & $\begin{array}{l}131 \text { BLOOR } \\
\text { STREET WEST } \\
\text { SPACE \#102 } \\
\text { TORONTO, } \\
\text { ON }\end{array}$ & ON & $\begin{array}{l}\text { M5S } \\
3 \mathrm{~L} 7\end{array}$ & Strip Mall \\
\hline Coach & USA & Burrand Street & Vancouver & $\begin{array}{l}755 \text { BURRARD } \\
\text { STREET UNIT } \\
\# 2 \\
\text { VANCOUVER, } \\
\text { BC } \\
\end{array}$ & $B C$ & $\begin{array}{l}62 \\
1 \times 6\end{array}$ & Strip Mall \\
\hline Coach & USA & $\begin{array}{l}\text { Canada One Factory } \\
\text { Outlets }\end{array}$ & St. Catharines - Niagara & $\begin{array}{l}7500 \text { Lundy's } \\
\text { Ln,, Niagara } \\
\text { Falls, ON }\end{array}$ & ON & $\begin{array}{l}\mathrm{L} 2 \mathrm{H} \\
1 \mathrm{G} 8\end{array}$ & Outlet Mall \\
\hline Coach & USA & Carrefour Laval & Montreal & $\begin{array}{l}3003 \\
\text { Boulevard Le } \\
\text { Carrefour, } \\
\text { Laval, QC }\end{array}$ & QC & $\begin{array}{l}\mathrm{H7T} \\
1 \mathrm{C} 8\end{array}$ & $\begin{array}{l}\text { Traditional Shopping } \\
\text { Center }\end{array}$ \\
\hline Coach & USA & Chinook Centre & Calgary & $\begin{array}{l}6455 \\
\text { Macleod Trail }\end{array}$ & $A B$ & $\begin{array}{l}\mathrm{T} 2 \mathrm{H} \\
\text { OK8 }\end{array}$ & $\begin{array}{l}\text { Traditional Shopping } \\
\text { Center }\end{array}$ \\
\hline
\end{tabular}




\begin{tabular}{|c|c|c|c|c|c|c|c|}
\hline Name & $\begin{array}{l}\text { Country } \\
\text { of Origin }\end{array}$ & Retail Location & CMA & Address & $\begin{array}{l}\text { Provin } \\
\text { ce }\end{array}$ & $\begin{array}{l}\text { Postal } \\
\text { Code }\end{array}$ & Retail Type \\
\hline & & & & $\begin{array}{l}\text { SW, Calgary, } \\
A B\end{array}$ & & & \\
\hline Coach & USA & $\begin{array}{l}\text { CrossIron Mills Outlets } \\
\text { Mall }\end{array}$ & Calgary & $\begin{array}{l}261055 \\
\text { Crossiron } \\
\text { Blvd, Rocky } \\
\text { View No. 44, } \\
\text { AB } \\
\end{array}$ & $A B$ & $\begin{array}{l}\text { T4A } \\
\text { OG3 }\end{array}$ & Outlet Mall \\
\hline Coach & USA & Don Mills & Toronto & $\begin{array}{l}16 \text { Aggie } \\
\text { Hogg } \\
\text { Gardens, } \\
\text { Toronto, ON }\end{array}$ & ON & $\begin{array}{l}\text { M3C } \\
\text { OG7 }\end{array}$ & Strip Mall \\
\hline Coach & USA & Fairview Park & $\begin{array}{l}\text { Kitchener - Cambridge - } \\
\text { Waterloo }\end{array}$ & $\begin{array}{l}2960 \\
\text { Kingsway Dr, } \\
\text { Kitchener, ON }\end{array}$ & ON & $\begin{array}{l}\mathrm{N} 2 \mathrm{C} \\
1 \mathrm{X} 1\end{array}$ & $\begin{array}{l}\text { Traditional Shopping } \\
\text { Center }\end{array}$ \\
\hline Coach & USA & Fairview Pointe Claire & Montreal & $\begin{array}{l}6801 \text { Trans } \\
\text { Canada } \\
\text { Highway, } \\
\text { Pointe-Claire, } \\
\text { QC }\end{array}$ & QC & $\begin{array}{l}\text { H9R } \\
5 J 2\end{array}$ & $\begin{array}{l}\text { Traditional Shopping } \\
\text { Center }\end{array}$ \\
\hline Coach & USA & $\begin{array}{l}\text { Mapleview Shopping } \\
\text { Centre }\end{array}$ & Hamilton & $\begin{array}{l}900 \text { Maple } \\
\text { Ave, } \\
\text { Burlington, } \\
\text { ON }\end{array}$ & ON & L7S 2J8 & $\begin{array}{l}\text { Traditional Shopping } \\
\text { Center }\end{array}$ \\
\hline Coach & USA & $\begin{array}{l}\text { Markville Shopping } \\
\text { Centre }\end{array}$ & Toronto & $\begin{array}{l}5000 \text { Hwy 7, } \\
\text { Markham, ON }\end{array}$ & ON & $\begin{array}{l}\text { L3R } \\
4 \mathrm{M} 9\end{array}$ & $\begin{array}{l}\text { Traditional Shopping } \\
\text { Center }\end{array}$ \\
\hline Coach & USA & Mayfair Shopping Centre & Victoria & $\begin{array}{l}3147 \text { Douglas } \\
\text { St, Victoria, } \\
\text { BC }\end{array}$ & BC & $\begin{array}{l}\text { V8Z } \\
6 \mathrm{E} 3\end{array}$ & $\begin{array}{l}\text { Traditional Shopping } \\
\text { Center }\end{array}$ \\
\hline Coach & USA & McArthurGlen Vancouver & Vancouver & $\begin{array}{l}7899 \\
\text { Templeton } \\
\text { Station Rd } \\
\text { \#1000, } \\
\text { Richmond, BC }\end{array}$ & $\mathrm{BC}$ & $\begin{array}{l}\text { V7B } \\
\text { OB7 }\end{array}$ & Outlet Mall \\
\hline Coach & USA & Metropolis at Metrotown & Vancouver & $\begin{array}{l}4700 \\
\text { Kingsway }\end{array}$ & $\mathrm{BC}$ & $\begin{array}{l}\mathrm{V} 5 \mathrm{H} \\
4 \mathrm{~N} 2 \\
\end{array}$ & $\begin{array}{l}\text { Traditional Shopping } \\
\text { Center }\end{array}$ \\
\hline
\end{tabular}




\begin{tabular}{|c|c|c|c|c|c|c|c|}
\hline Name & $\begin{array}{l}\text { Country } \\
\text { of Origin }\end{array}$ & Retail Location & CMA & Address & $\begin{array}{l}\text { Provin } \\
\text { ce }\end{array}$ & $\begin{array}{l}\text { Postal } \\
\text { Code }\end{array}$ & Retail Type \\
\hline & & & & $\begin{array}{l}\# 604, \\
\text { Burnaby, BC }\end{array}$ & & & \\
\hline Coach & USA & Oakridge Centre & Vancouver & $\begin{array}{l}650 \text { W 41st } \\
\text { Ave, } \\
\text { Vancouver, } \\
\text { BC }\end{array}$ & $\mathrm{BC}$ & $\begin{array}{l}\text { V5Z } \\
2 \mathrm{M} 9\end{array}$ & $\begin{array}{l}\text { Traditional Shopping } \\
\text { Center }\end{array}$ \\
\hline Coach & USA & $\begin{array}{l}\text { Outlet Collection at } \\
\text { Niagara }\end{array}$ & St. Catharines - Niagara & $\begin{array}{l}300 \text { Taylor } \\
\text { Rd, Niagara- } \\
\text { on-the-Lake, } \\
\text { ON }\end{array}$ & ON & $\begin{array}{l}\mathrm{L} 2 \mathrm{H} \\
1 \mathrm{G} 8\end{array}$ & Outlet Mall \\
\hline Coach & USA & Pacific Centre & Vancouver & $\begin{array}{l}701 \mathrm{~W} \\
\text { Georgia St, } \\
\text { Vancouver, } \\
\text { BC }\end{array}$ & $\mathrm{BC}$ & $\begin{array}{l}\text { V7Y } \\
1 G 5\end{array}$ & Major Downtown Mall \\
\hline Coach & USA & $\begin{array}{l}\text { Pearson Airport Terminal } \\
1\end{array}$ & Toronto & $\begin{array}{l}5675 \text { Silver } \\
\text { Dart Dr, } \\
\text { Mississauga, } \\
\text { ON }\end{array}$ & ON & $\begin{array}{l}\text { L5P } \\
1 B 2\end{array}$ & Airport \\
\hline Coach & USA & Promenade Mall & Toronto & $\begin{array}{l}1 \text { Promenade } \\
\text { Cir, Thornhill, } \\
\text { ON }\end{array}$ & ON & L4J 4P8 & $\begin{array}{l}\text { Traditional Shopping } \\
\text { Center }\end{array}$ \\
\hline Coach & USA & Richmond Centre & Vancouver & $\begin{array}{l}6551 \text { No } 3 \text { Rd, } \\
\text { Richmond, BC }\end{array}$ & $\mathrm{BC}$ & $\begin{array}{l}\text { V6Y } \\
2 B 6\end{array}$ & $\begin{array}{l}\text { Traditional Shopping } \\
\text { Center }\end{array}$ \\
\hline Coach & USA & Rideau Centre & Ottawa - Gatineau & $\begin{array}{l}50 \text { Rideau St } \\
\# 300, \text { Ottawa, } \\
\text { ON }\end{array}$ & ON & $\begin{array}{l}\text { K1N } \\
9 J 7\end{array}$ & Major Downtown Mall \\
\hline Coach & USA & Sherway Gardens & Toronto & $\begin{array}{l}25 \text { The West } \\
\text { Mall, } \\
\text { Etobicoke, } \\
\text { ON }\end{array}$ & ON & $\begin{array}{l}\text { M9C } \\
1 \mathrm{~B} 8\end{array}$ & $\begin{array}{l}\text { Traditional Shopping } \\
\text { Center }\end{array}$ \\
\hline Coach & USA & Southgate Centre & Edmonton & $\begin{array}{l}5015111 \mathrm{St} \\
\mathrm{NW}, \\
\text { Edmonton, } \\
\mathrm{AB}\end{array}$ & $A B$ & $\begin{array}{l}\mathrm{T} 6 \mathrm{H} \\
4 \mathrm{M} 6\end{array}$ & $\begin{array}{l}\text { Traditional Shopping } \\
\text { Center }\end{array}$ \\
\hline
\end{tabular}




\begin{tabular}{|c|c|c|c|c|c|c|c|}
\hline Name & $\begin{array}{l}\text { Country } \\
\text { of Origin }\end{array}$ & Retail Location & CMA & Address & $\begin{array}{l}\text { Provin } \\
\text { ce }\end{array}$ & $\begin{array}{l}\text { Postal } \\
\text { Code }\end{array}$ & Retail Type \\
\hline Coach & USA & Square One & Toronto & $\begin{array}{l}100 \text { City } \\
\text { Centre Dr, } \\
\text { Mississauga, } \\
\text { ON }\end{array}$ & ON & $\begin{array}{l}\text { L5B } \\
2 \mathrm{C} 9\end{array}$ & $\begin{array}{l}\text { Traditional Shopping } \\
\text { Center }\end{array}$ \\
\hline Coach & USA & Tanger Outlet Cookstown & Barrie & $\begin{array}{l}3311 \text { Simcoe } \\
\text { 89, Innisfil, } \\
\text { ON }\end{array}$ & ON & LOL 1L0 & Outlet Mall \\
\hline Coach & USA & Tanger Outlet Ottawa & Ottawa - Gatineau & $\begin{array}{l}8555 \\
\text { Campeau Dr, } \\
\text { Ottawa, ON }\end{array}$ & ON & $\begin{array}{l}\text { K2T } \\
\text { OK5 }\end{array}$ & Outlet Mall \\
\hline Coach & USA & Toronto Eaton Centre & Toronto & $\begin{array}{l}220 \text { Yonge St, } \\
\text { Toronto, ON }\end{array}$ & ON & $\begin{array}{l}\mathrm{M} 5 \mathrm{~B} \\
2 \mathrm{H} 1\end{array}$ & Major Downtown Mall \\
\hline Coach & USA & Toronto Premium Outlet & Toronto & $\begin{array}{l}13850 \text { Steeles } \\
\text { Avenue W, } \\
\text { Halton Hills, } \\
\text { ON }\end{array}$ & ON & L7G 0J1 & Outlet Mall \\
\hline Coach & USA & Upper Canada Mall & Toronto & $\begin{array}{l}17600 \text { Yonge } \\
\text { St, } \\
\text { Newmarket, } \\
\text { ON }\end{array}$ & ON & L3Y 4Z1 & $\begin{array}{l}\text { Traditional Shopping } \\
\text { Center }\end{array}$ \\
\hline Coach & USA & West Edmonton Mall & Edmonton & $\begin{array}{l}8882170 \mathrm{St} \\
\mathrm{NW}, \\
\text { Edmonton, } \\
\mathrm{AB}\end{array}$ & $A B$ & T5T 4J2 & $\begin{array}{l}\text { Traditional Shopping } \\
\text { Center }\end{array}$ \\
\hline Coach & USA & Yorkdale Shopping Centre & Toronto & $\begin{array}{l}3401 \text { Dufferin } \\
\text { Street Unit } \\
217 \text {, Toronto, } \\
\text { ON }\end{array}$ & ON & $\begin{array}{l}\text { M6A } \\
2 T 9\end{array}$ & $\begin{array}{l}\text { Traditional Shopping } \\
\text { Center }\end{array}$ \\
\hline Coach Outlet & USA & MIRABEL OUTLET & Montreal & $\begin{array}{l}19001 \\
\text { Chemin Notre } \\
\text { Dame, } \\
\text { Mirabel, QC }\end{array}$ & QC & J7J0T1 & Outlet Mall \\
\hline $\cos$ & Sweden & Bloor Street & Toronto & $\begin{array}{l}85 \text { Bloor } \\
\text { Street West }\end{array}$ & ON & $\begin{array}{l}\text { M5S } \\
1 \mathrm{M} 1 \\
\end{array}$ & Strip Mall \\
\hline
\end{tabular}




\begin{tabular}{|c|c|c|c|c|c|c|c|}
\hline Name & $\begin{array}{l}\text { Country } \\
\text { of Origin }\end{array}$ & Retail Location & CMA & Address & $\begin{array}{l}\text { Provin } \\
\text { ce }\end{array}$ & $\begin{array}{l}\text { Postal } \\
\text { Code }\end{array}$ & Retail Type \\
\hline $\cos$ & Sweden & $\begin{array}{l}\text { Rue Sainte-Catherine } \\
\text { Ouest }\end{array}$ & Montreal & $\begin{array}{l}1310 \text { Rue } \\
\text { Sainte- } \\
\text { Catherine } \\
\text { Ouest }\end{array}$ & $Q C$ & $\begin{array}{l}\mathrm{H} 3 \mathrm{G} \\
1 \mathrm{P} 6\end{array}$ & Strip Mall \\
\hline $\cos$ & Sweden & Yorkdale Shopping Centre & Toronto & $\begin{array}{l}3401 \text { Dufferin } \\
\text { Street Unit } \\
217 \text {, Toronto, } \\
\text { ON }\end{array}$ & ON & $\begin{array}{l}\text { M6A } \\
2 T 9\end{array}$ & $\begin{array}{l}\text { Traditional Shopping } \\
\text { Center }\end{array}$ \\
\hline DAVID YURMAN & USA & Yorkdale Shopping Centre & Toronto & $\begin{array}{l}\text { 3401 Dufferin } \\
\text { Street Unit } \\
\text { 217, Toronto, } \\
\text { ON }\end{array}$ & ON & $\begin{array}{l}\text { M6A } \\
2 \mathrm{~T} 9\end{array}$ & $\begin{array}{l}\text { Traditional Shopping } \\
\text { Center }\end{array}$ \\
\hline Dolce \& Gabbana & Italy & Bloor Street & Toronto & $\begin{array}{l}111 \text { Bloor } \\
\text { Street West }\end{array}$ & ON & $\begin{array}{l}\text { M5S } \\
1 \mathrm{M} 4\end{array}$ & Strip Mall \\
\hline Eileen Fisher & USA & Chinook Centre & Calgary & $\begin{array}{l}6455 \\
\text { Macleod Trail } \\
\text { SW, Calgary, } \\
\text { AB }\end{array}$ & $A B$ & $\begin{array}{l}\mathrm{T} 2 \mathrm{H} \\
0 \mathrm{~K} 8\end{array}$ & $\begin{array}{l}\text { Traditional Shopping } \\
\text { Center }\end{array}$ \\
\hline Eileen Fisher & USA & Granville Street & Vancouver & \begin{tabular}{|l}
2721 \\
Granville St, \\
Vancouver, \\
BC \\
\end{tabular} & $\mathrm{BC}$ & $\begin{array}{l}\text { V6H } \\
3 J 1\end{array}$ & Strip Mall \\
\hline Eileen Fisher & USA & Sherway Gardens & Toronto & $\begin{array}{l}25 \text { The West } \\
\text { Mall, } \\
\text { Etobicoke, } \\
\text { ON }\end{array}$ & ON & $\begin{array}{l}\text { M9C } \\
1 \mathrm{~B} 8\end{array}$ & $\begin{array}{l}\text { Traditional Shopping } \\
\text { Center }\end{array}$ \\
\hline Ermenegildo Zegna & Italy & Pacific Centre & Vancouver & \begin{tabular}{|l|}
$701 \mathrm{~W}$ \\
Georgia St, \\
Vancouver, \\
BC
\end{tabular} & $\mathrm{BC}$ & $\begin{array}{l}\text { V7Y } \\
1 G 5\end{array}$ & Major Downtown Mall \\
\hline Escada & Germany & Bloor Street & Toronto & $\begin{array}{l}131 \text { Bloor } \\
\text { Street West } \\
\text { Unit } 111\end{array}$ & ON & $\begin{array}{l}\text { M5S } \\
\text { 1R1 }\end{array}$ & Strip Mall \\
\hline
\end{tabular}




\begin{tabular}{|c|c|c|c|c|c|c|c|}
\hline Name & $\begin{array}{l}\text { Country } \\
\text { of Origin }\end{array}$ & Retail Location & CMA & Address & $\begin{array}{l}\text { Provin } \\
\text { ce }\end{array}$ & $\begin{array}{l}\text { Postal } \\
\text { Code }\end{array}$ & Retail Type \\
\hline Escada & Germany & $\begin{array}{l}\text { Canada One Factory } \\
\text { Outlets }\end{array}$ & St. Catharines - Niagara & $\begin{array}{l}7500 \text { Lundy's } \\
\text { Ln, Niagara } \\
\text { Falls, ON }\end{array}$ & ON & $\begin{array}{l}\mathrm{L} 2 \mathrm{H} \\
1 \mathrm{G} 9\end{array}$ & Outlet Mall \\
\hline Escada & Germany & Commerce Place & Edmonton & $\begin{array}{l}10180101 \mathrm{St} \\
\mathrm{NW}, \\
\text { Edmonton, } \\
\mathrm{AB}\end{array}$ & $A B$ & T5J 3S4 & Ancillary \\
\hline Escada & Germany & $\begin{array}{l}\text { Rue Sainte-Catherine } \\
\text { Ouest }\end{array}$ & Montreal & $\begin{array}{l}1214 \text { Rue } \\
\text { Sherbrooke } \\
\text { Ouest }\end{array}$ & QC & $\begin{array}{l}\mathrm{H} 3 \mathrm{~A} \\
1 \mathrm{H} 6\end{array}$ & Strip Mall \\
\hline Escada & Germany & Thurlow Street & Vancouver & $\begin{array}{l}710 \text { Thurlow } \\
\text { Street }\end{array}$ & $\mathrm{BC}$ & $\begin{array}{l}\text { V6E } \\
1 \mathrm{~V} 8\end{array}$ & Strip Mall \\
\hline Fred Perry & UK & Queen Street West & Toronto & $\begin{array}{l}964 \text { Queen } \\
\text { Street West } \\
\text { Toronto, ON }\end{array}$ & ON & $\begin{array}{l}\mathrm{M} 6 \mathrm{~J} \\
1 \mathrm{G} 8\end{array}$ & Strip Mall \\
\hline George Rech & France & Avenue Greene & Montreal & $\begin{array}{l}1277 \text { Avenue } \\
\text { Greene, } \\
\text { Westmount, } \\
\text { QC }\end{array}$ & QC & $\begin{array}{l}\mathrm{H} 3 \mathrm{Z} \\
2 \mathrm{~A} 4\end{array}$ & Strip Mall \\
\hline George Rech & France & Yorkville & Toronto & $\begin{array}{l}101 \text { Yorkville } \\
\text { Ave, Toronto, } \\
\text { ON }\end{array}$ & ON & $\begin{array}{l}\text { M5R } \\
1 \mathrm{C} 1\end{array}$ & Strip Mall \\
\hline Georges Rech & France & Yorkville & Toronto & $\begin{array}{l}55 \text { Avenue } \\
\text { Rd, Toronto, } \\
\text { ON }\end{array}$ & ON & $\begin{array}{l}\text { M5R } \\
3 R 9\end{array}$ & Strip Mall \\
\hline Gucci & USA & Bloor Street & Toronto & $\begin{array}{l}130 \text { Bloor St } \\
\text { W }\end{array}$ & ON & $\begin{array}{l}\text { M5S } \\
1 \mathrm{~N} 5\end{array}$ & Strip Mall \\
\hline Gucci & USA & MIRABEL OUTLET & Montreal & $\begin{array}{l}19001 \\
\text { Chemin Notre } \\
\text { Dame, } \\
\text { Mirabel, QC }\end{array}$ & $Q C$ & J7J0T1 & Outlet Mall \\
\hline Gucci & USA & $\begin{array}{l}\text { Pearson Airport Terminal } \\
1\end{array}$ & Toronto & $\begin{array}{l}675 \text { Silver } \\
\text { Dart Dr, } \\
\text { Mississauga, } \\
\text { ON }\end{array}$ & ON & $\begin{array}{l}\text { L5P } \\
1 B 2\end{array}$ & Airport \\
\hline
\end{tabular}




\begin{tabular}{|c|c|c|c|c|c|c|c|}
\hline Name & $\begin{array}{l}\text { Country } \\
\text { of Origin }\end{array}$ & Retail Location & CMA & Address & $\begin{array}{l}\text { Provin } \\
\text { ce }\end{array}$ & $\begin{array}{l}\text { Postal } \\
\text { Code }\end{array}$ & Retail Type \\
\hline Gucci & USA & $\begin{array}{l}\text { The Fairmont Hotel } \\
\text { Vancouver }\end{array}$ & Vancouver & $\begin{array}{l}900 \text { West } \\
\text { Georgia } \\
\text { Street } \\
\text { Vancouver, } \\
\text { British } \\
\text { Columbia }\end{array}$ & $\mathrm{BC}$ & $\begin{array}{l}\text { V6C } \\
2 \mathrm{~W} 6\end{array}$ & Ancillary \\
\hline Gucci & USA & $\begin{array}{l}\text { Vancouver International } \\
\text { Airport }\end{array}$ & Vancouver & $\begin{array}{l}3211 \text { Grant } \\
\text { McConachie } \\
\text { Way, } \\
\text { Richmond, BC }\end{array}$ & $\mathrm{BC}$ & $\begin{array}{l}\text { V7B } \\
\text { OA4 }\end{array}$ & Airport \\
\hline Hermès & France & Bloor Street & Toronto & $\begin{array}{l}130 \text { Bloor St } \\
\text { W, Toronto, } \\
\text { ON }\end{array}$ & ON & $\begin{array}{l}\text { M5S } \\
1 \mathrm{~N} 5\end{array}$ & Strip Mall \\
\hline Hermès & France & Burrand Street & Vancouver & $\begin{array}{l}755 \text { Burrard } \\
\text { St, } \\
\text { Vancouver, } \\
\text { BC }\end{array}$ & $\mathrm{BC}$ & $\begin{array}{l}62 \\
1 \times 6\end{array}$ & Strip Mall \\
\hline Hermès & France & $\begin{array}{l}\text { Vancouver International } \\
\text { Airport }\end{array}$ & Vancouver & $\begin{array}{l}3211 \text { Grant } \\
\text { McConachie } \\
\text { Way, } \\
\text { Richmond, BC }\end{array}$ & $\mathrm{BC}$ & $\begin{array}{l}\text { V7B } \\
\text { OA4 }\end{array}$ & Airport \\
\hline Hugo Boss & Germany & McArthurGlen Vancouver & Vancouver & $\begin{array}{l}7899 \\
\text { Templeton } \\
\text { Station Rd } \\
\text { \#1000, } \\
\text { Richmond, BC }\end{array}$ & $\mathrm{BC}$ & $\begin{array}{l}\text { V7B } \\
\text { OB7 }\end{array}$ & Outlet Mall \\
\hline Hugo Boss & Germany & $\begin{array}{l}\text { Outlet Collection at } \\
\text { Niagara }\end{array}$ & Vancouver & $\begin{array}{l}650 \text { W 41st } \\
\text { Ave, } \\
\text { Vancouver, } \\
\text { BC }\end{array}$ & $\mathrm{BC}$ & $\begin{array}{l}\mathrm{V} 5 \mathrm{Z} \\
2 \mathrm{M} 9\end{array}$ & $\begin{array}{l}\text { Traditional Shopping } \\
\text { Center }\end{array}$ \\
\hline Hugo Boss & Germany & Pacific Centre & Vancouver & $\begin{array}{l}701 \mathrm{~W} \\
\text { Georgia St, } \\
\text { Vancouver, } \\
\text { BC }\end{array}$ & $\mathrm{BC}$ & $\begin{array}{l}\text { V7Y } \\
1 G 5\end{array}$ & Major Downtown Mall \\
\hline
\end{tabular}




\begin{tabular}{|c|c|c|c|c|c|c|c|}
\hline Name & $\begin{array}{l}\text { Country } \\
\text { of Origin }\end{array}$ & Retail Location & CMA & Address & $\begin{array}{l}\text { Provin } \\
\text { ce }\end{array}$ & $\begin{array}{l}\text { Postal } \\
\text { Code }\end{array}$ & Retail Type \\
\hline Hugo Boss Outlet & Germany & Bloor Street & Toronto & $\begin{array}{l}83 \text { Bloor St } \\
\text { W, Toronto, } \\
\text { ON }\end{array}$ & ON & $\begin{array}{l}\text { M5S } \\
1 \mathrm{M} 1\end{array}$ & Strip Mall \\
\hline Hugo Boss Outlet & Germany & Chinook Centre & Calgary & $\begin{array}{l}6455 \\
\text { Macleod Trail } \\
\text { SW, Calgary, } \\
\text { AB }\end{array}$ & $A B$ & $\begin{array}{l}\mathrm{T} 2 \mathrm{H} \\
\mathrm{OK} 8\end{array}$ & $\begin{array}{l}\text { Traditional Shopping } \\
\text { Center }\end{array}$ \\
\hline Hugo Boss Outlet & Germany & $\begin{array}{l}\text { CrossIron Mills Outlets } \\
\text { Mall }\end{array}$ & Calgary & $\begin{array}{l}261055 \\
\text { Crossiron } \\
\text { Blvd, Rocky } \\
\text { View No. 44, } \\
\text { AB }\end{array}$ & $A B$ & $\begin{array}{l}\text { T4A } \\
0 G 3\end{array}$ & Outlet Mall \\
\hline Hugo Boss Outlet & Germany & MIRABEL OUTLET & Montreal & $\begin{array}{l}19001 \\
\text { Chemin Notre } \\
\text { Dame, } \\
\text { Mirabel, QC }\end{array}$ & QC & J7J0T1 & Outlet Mall \\
\hline Hugo Boss Outlet & Germany & $\begin{array}{l}\text { Outlet Collection at } \\
\text { Niagara }\end{array}$ & St. Catharines - Niagara & $\begin{array}{l}300 \text { Taylor } \\
\text { Rd, Niagara- } \\
\text { on-the-Lake, } \\
\text { ON }\end{array}$ & ON & LOS 1J0 & Outlet Mall \\
\hline Hugo Boss Outlet & Germany & Richmond Centre & Vancouver & $\begin{array}{l}6551 \text { No } 3 \mathrm{Rd}, \\
\text { Richmond, BC }\end{array}$ & $B C$ & $\begin{array}{l}\text { V6Y } \\
\text { 2B6 }\end{array}$ & $\begin{array}{l}\text { Traditional Shopping } \\
\text { Center }\end{array}$ \\
\hline Hugo Boss Outlet & Germany & $\begin{array}{l}\text { Rue Sainte-Catherine } \\
\text { Ouest }\end{array}$ & Montreal & $\begin{array}{l}1307 \text { Ste. } \\
\text { Catherine } \\
\text { Street Ouest, } \\
\text { Montréal, QC }\end{array}$ & QC & $\begin{array}{l}\text { H3G } \\
1 P 7\end{array}$ & Strip Mall \\
\hline Hugo Boss Outlet & Germany & Sherway Gardens & Toronto & $\begin{array}{l}25 \text { The West } \\
\text { Mall, } \\
\text { Etobicoke, } \\
\text { ON }\end{array}$ & ON & $\begin{array}{l}\mathrm{M9C} \\
1 \mathrm{~B} 8\end{array}$ & $\begin{array}{l}\text { Traditional Shopping } \\
\text { Center }\end{array}$ \\
\hline Hugo Boss Outlet & Germany & Toronto Eaton Centre & Toronto & $\begin{array}{l}220 \text { Yonge St, } \\
\text { Toronto, ON }\end{array}$ & ON & $\begin{array}{l}\mathrm{M} 5 \mathrm{~B} \\
2 \mathrm{H} 1 \\
\end{array}$ & Major Downtown Mall \\
\hline Hugo Boss Outlet & Germany & Toronto Premium Outlet & Toronto & $\begin{array}{l}13850 \text { Steeles } \\
\text { Avenue W, }\end{array}$ & ON & L7G 0J1 & Outlet Mall \\
\hline
\end{tabular}




\begin{tabular}{|c|c|c|c|c|c|c|c|}
\hline Name & $\begin{array}{l}\text { Country } \\
\text { of Origin }\end{array}$ & Retail Location & CMA & Address & $\begin{array}{l}\text { Provin } \\
\text { ce }\end{array}$ & $\begin{array}{l}\text { Postal } \\
\text { Code }\end{array}$ & Retail Type \\
\hline & & & & $\begin{array}{l}\text { Halton Hills, } \\
\text { ON }\end{array}$ & & & \\
\hline Hugo Boss Outlet & Germany & Vaughan Mills & Toronto & $\begin{array}{l}1 \text { Bass Pro } \\
\text { Mills Dr, } \\
\text { Concord, ON }\end{array}$ & ON & $\begin{array}{l}\text { L4K } \\
5 W 4\end{array}$ & Outlet Mall \\
\hline Hugo Boss Outlet & Germany & West Edmonton Mall & Edmonton & $\begin{array}{l}8882170 \mathrm{St} \\
\mathrm{NW}, \\
\text { Edmonton, } \\
\mathrm{AB}\end{array}$ & $A B$ & T5T 4J2 & $\begin{array}{l}\text { Traditional Shopping } \\
\text { Center }\end{array}$ \\
\hline Hugo Boss Outlet & Germany & Yorkdale Shopping Centre & Toronto & $\begin{array}{l}3401 \text { Dufferin } \\
\text { Street Unit } \\
217 \text {, Toronto, } \\
\text { ON }\end{array}$ & ON & $\begin{array}{l}\text { M6A } \\
2 \mathrm{~T} 9\end{array}$ & $\begin{array}{l}\text { Traditional Shopping } \\
\text { Center }\end{array}$ \\
\hline Jaeger Lecoultre & Swiss & Alberni Street & Vancouver & $\begin{array}{l}1012 \text { Alberni } \\
\text { Street, } \\
\text { Vanvouver, } \\
\text { BC }\end{array}$ & $\mathrm{BC}$ & $\begin{array}{l}\text { V6E } \\
1 \mathrm{~A} 3\end{array}$ & Strip Mall \\
\hline Jaeger Lecoultre & Swiss & Yorkdale Shopping Centre & Toronto & $\begin{array}{l}\text { 3401 Dufferin } \\
\text { Street Unit } \\
217 \text {, Toronto, } \\
\text { ON }\end{array}$ & ON & $\begin{array}{l}\text { M6A } \\
\text { 2T9 }\end{array}$ & $\begin{array}{l}\text { Traditional Shopping } \\
\text { Center }\end{array}$ \\
\hline Jimmy Choo & UK & Toronto Premium Outlet & Toronto & $\begin{array}{l}13850 \text { Steeles } \\
\text { Avenue W, } \\
\text { Halton Hills, } \\
\text { ON }\end{array}$ & ON & L7G 0J1 & Outlet Mall \\
\hline Jimmy Choo & UK & Yorkdale Shopping Centre & Toronto & $\begin{array}{l}3401 \text { Dufferin } \\
\text { Street Unit } \\
217 \text {, Toronto, } \\
\text { ON }\end{array}$ & ON & $\begin{array}{l}\text { M6A } \\
\text { 2T9 }\end{array}$ & $\begin{array}{l}\text { Traditional Shopping } \\
\text { Center }\end{array}$ \\
\hline John Varvatos & USA & Yorkdale Shopping Centre & Toronto & $\begin{array}{l}3401 \text { Dufferin } \\
\text { Street Unit } \\
217 \text {, Toronto, } \\
\text { ON }\end{array}$ & ON & $\begin{array}{l}\text { M6A } \\
\text { 2T9 }\end{array}$ & $\begin{array}{l}\text { Traditional Shopping } \\
\text { Center }\end{array}$ \\
\hline Kate Spade & USA & Chinook Centre & Calgary & $\begin{array}{l}6455 \\
\text { Macleod Trail }\end{array}$ & $A B$ & $\begin{array}{l}\mathrm{T} 2 \mathrm{H} \\
\mathrm{OK} 8\end{array}$ & $\begin{array}{l}\text { Traditional Shopping } \\
\text { Center }\end{array}$ \\
\hline
\end{tabular}




\begin{tabular}{|c|c|c|c|c|c|c|c|}
\hline Name & $\begin{array}{l}\text { Country } \\
\text { of Origin }\end{array}$ & Retail Location & CMA & Address & $\begin{array}{l}\text { Provin } \\
\text { ce }\end{array}$ & $\begin{array}{l}\text { Postal } \\
\text { Code }\end{array}$ & Retail Type \\
\hline & & & & $\begin{array}{l}\text { SW, Calgary, } \\
\text { AB }\end{array}$ & & & \\
\hline Kate Spade & USA & $\begin{array}{l}\text { Outlet Collection at } \\
\text { Niagara }\end{array}$ & St. Catharines - Niagara & $\begin{array}{l}300 \text { Taylor } \\
\text { Rd, Niagara- } \\
\text { on-the-Lake, } \\
\text { ON }\end{array}$ & ON & LOS $1 \mathrm{JO}$ & Outlet Mall \\
\hline Kate Spade & USA & Pacific Centre & Vancouver & $\begin{array}{l}701 \text { W } \\
\text { Georgia St, } \\
\text { Vancouver, } \\
\text { BC }\end{array}$ & $\mathrm{BC}$ & $\begin{array}{l}\text { V7Y } \\
1 G 5\end{array}$ & Major Downtown Mall \\
\hline Kate Spade & USA & $\begin{array}{l}\text { Park Royal Shopping } \\
\text { Centre }\end{array}$ & Vancouver & $\begin{array}{l}\text { Park Royal } \\
925 \text { Main St. }\end{array}$ & $\mathrm{BC}$ & $\begin{array}{l}\text { V7T } \\
2 \mathrm{~W} 4\end{array}$ & Strip Mall \\
\hline Kate Spade & USA & Rideau Centre & Ottawa - Gatineau & $\begin{array}{l}50 \text { Rideau St } \\
\# 300, \text { Ottawa, } \\
\text { ON }\end{array}$ & ON & $\begin{array}{l}\text { K1N } \\
9 J 7\end{array}$ & Major Downtown Mall \\
\hline Kate Spade & USA & Sherway Gardens & Toronto & $\begin{array}{l}25 \text { The West } \\
\text { Mall, } \\
\text { Etobicoke, } \\
\text { ON }\end{array}$ & ON & $\begin{array}{l}\mathrm{M9C} \\
1 \mathrm{~B} 8\end{array}$ & $\begin{array}{l}\text { Traditional Shopping } \\
\text { Center }\end{array}$ \\
\hline Kate Spade & USA & Square One & Toronto & $\begin{array}{l}100 \text { City } \\
\text { Centre Dr, } \\
\text { Mississauga, } \\
\text { ON }\end{array}$ & ON & $\begin{array}{l}\text { L5B } \\
2 \mathrm{C} 9\end{array}$ & $\begin{array}{l}\text { Traditional Shopping } \\
\text { Center }\end{array}$ \\
\hline Kate Spade & USA & Toronto Eaton Centre & Toronto & $\begin{array}{l}220 \text { Yonge St, } \\
\text { Toronto, ON }\end{array}$ & ON & $\begin{array}{l}\mathrm{M} 5 \mathrm{~B} \\
2 \mathrm{H} 1\end{array}$ & Major Downtown Mall \\
\hline Kate Spade & USA & Toronto Premium Outlet & Toronto & $\begin{array}{l}13850 \text { Steeles } \\
\text { Avenue W, } \\
\text { Halton Hills, } \\
\text { ON }\end{array}$ & ON & L7G 0J1 & Outlet Mall \\
\hline Kate Spade & USA & Vaughan Mills & Toronto & $\begin{array}{l}1 \text { Bass Pro } \\
\text { Mills Dr, } \\
\text { Concord, ON }\end{array}$ & ON & $\begin{array}{l}\text { L4K } \\
5 \mathrm{~W} 4\end{array}$ & Outlet Mall \\
\hline Kate Spade & USA & Yorkdale Shopping Centre & Toronto & $\begin{array}{l}3401 \text { Dufferin } \\
\text { Street Unit }\end{array}$ & ON & $\begin{array}{l}\text { M6A } \\
2 T 9\end{array}$ & $\begin{array}{l}\text { Traditional Shopping } \\
\text { Center }\end{array}$ \\
\hline
\end{tabular}




\begin{tabular}{|c|c|c|c|c|c|c|c|}
\hline Name & $\begin{array}{l}\text { Country } \\
\text { of Origin }\end{array}$ & Retail Location & CMA & Address & $\begin{array}{l}\text { Provin } \\
\text { ce }\end{array}$ & $\begin{array}{l}\text { Postal } \\
\text { Code }\end{array}$ & Retail Type \\
\hline & & & & $\begin{array}{l}\text { 217, Toronto, } \\
\text { ON }\end{array}$ & & & \\
\hline Kate Spade & USA & Yorkville & Toronto & $\begin{array}{l}138 \\
\text { CUMBERLAN } \\
\text { D STREET } \\
\text { TORONTO, } \\
\text { ON }\end{array}$ & ON & $\begin{array}{l}\text { M5R } \\
\text { 3N7 }\end{array}$ & Strip Mall \\
\hline Lacoste & France & Carrefour Laval & Montreal & $\begin{array}{l}3003 \\
\text { Boulevard Le } \\
\text { Carrefour, } \\
\text { Laval, QC }\end{array}$ & QC & $\begin{array}{l}\mathrm{H7T} \\
1 \mathrm{C} 8\end{array}$ & $\begin{array}{l}\text { Traditional Shopping } \\
\text { Center }\end{array}$ \\
\hline Lacoste & France & Chinook Centre & Calgary & $\begin{array}{l}6455 \\
\text { Macleod Trail } \\
\text { SW, Calgary, } \\
\text { AB }\end{array}$ & $A B$ & $\begin{array}{l}\mathrm{T} 2 \mathrm{H} \\
\text { OK8 }\end{array}$ & $\begin{array}{l}\text { Traditional Shopping } \\
\text { Center }\end{array}$ \\
\hline Lacoste & France & MIRABEL OUTLET & Montreal & $\begin{array}{l}19001 \\
\text { Chemin Notre } \\
\text { Dame, } \\
\text { Mirabel, QC }\end{array}$ & QC & J7J0T1 & Outlet Mall \\
\hline Lacoste & France & Oakridge Centre & Vancouver & $\begin{array}{l}650 \text { W 41st } \\
\text { Ave, } \\
\text { Vancouver, } \\
\text { BC }\end{array}$ & $\mathrm{BC}$ & $\begin{array}{l}\text { V5Z } \\
2 \mathrm{M} 9\end{array}$ & $\begin{array}{l}\text { Traditional Shopping } \\
\text { Center }\end{array}$ \\
\hline Lacoste & France & $\begin{array}{l}\text { Outlet Collection at } \\
\text { Niagara }\end{array}$ & St. Catharines - Niagara & $\begin{array}{l}300 \text { Taylor } \\
\text { Rd, Niagara- } \\
\text { on-the-Lake, } \\
\text { ON }\end{array}$ & ON & LOS 1JO & Outlet Mall \\
\hline Lacoste & France & Rideau Centre & Ottawa - Gatineau & $\begin{array}{l}50 \text { Rideau St } \\
\# 300 \text {, Ottawa, } \\
\text { ON }\end{array}$ & ON & $\begin{array}{l}\text { K1N } \\
9 J 7\end{array}$ & Major Downtown Mall \\
\hline Lacoste & France & $\begin{array}{l}\text { Rue Sainte-Catherine } \\
\text { Ouest }\end{array}$ & Montreal & $\begin{array}{l}1011 \text { RUE } \\
\text { STE- } \\
\text { CATHERINE } \\
\text { OUEST }\end{array}$ & $Q C$ & $\begin{array}{l}\text { H3B } \\
2 \mathrm{~V} 5\end{array}$ & Strip Mall \\
\hline
\end{tabular}




\begin{tabular}{|c|c|c|c|c|c|c|c|}
\hline Name & $\begin{array}{l}\text { Country } \\
\text { of Origin }\end{array}$ & Retail Location & CMA & Address & $\begin{array}{l}\text { Provin } \\
\text { ce }\end{array}$ & $\begin{array}{l}\text { Postal } \\
\text { Code }\end{array}$ & Retail Type \\
\hline Lacoste & France & Sherway Gardens & Toronto & $\begin{array}{l}25 \text { The West } \\
\text { Mall, } \\
\text { Etobicoke, } \\
\text { ON }\end{array}$ & ON & $\begin{array}{l}\mathrm{M} 9 \mathrm{C} \\
1 \mathrm{~B} 8\end{array}$ & $\begin{array}{l}\text { Traditional Shopping } \\
\text { Center }\end{array}$ \\
\hline Lacoste & France & Square One & Toronto & $\begin{array}{l}100 \text { City } \\
\text { Centre Dr, } \\
\text { Mississauga, } \\
\text { ON }\end{array}$ & ON & $\begin{array}{l}\mathrm{L5B} \\
2 \mathrm{C} 9\end{array}$ & $\begin{array}{l}\text { Traditional Shopping } \\
\text { Center }\end{array}$ \\
\hline Lacoste & France & Toronto Eaton Centre & Toronto & $\begin{array}{l}220 \text { Yonge St, } \\
\text { Toronto, ON }\end{array}$ & ON & $\begin{array}{l}\mathrm{M} 5 \mathrm{~B} \\
2 \mathrm{H} 1\end{array}$ & Major Downtown Mall \\
\hline Lacoste & France & Vaughan Mills & Toronto & $\begin{array}{l}1 \text { Bass Pro } \\
\text { Mills Dr, } \\
\text { Concord, ON }\end{array}$ & ON & $\begin{array}{l}\mathrm{L} 4 \mathrm{~K} \\
5 \mathrm{~W} 4\end{array}$ & Outlet Mall \\
\hline Lacoste & France & West Edmonton Mall & Edmonton & $\begin{array}{l}8882170 \text { St } \\
\text { NW, } \\
\text { Edmonton, } \\
\text { AB }\end{array}$ & $A B$ & T5T 4J2 & $\begin{array}{l}\text { Traditional Shopping } \\
\text { Center }\end{array}$ \\
\hline Lacoste & France & Yorkdale Shopping Centre & Toronto & $\begin{array}{l}3401 \text { Dufferin } \\
\text { Street Unit } \\
217 \text {, Toronto, } \\
\text { ON }\end{array}$ & ON & $\begin{array}{l}\mathrm{M} 6 \mathrm{~A} \\
2 \mathrm{~T} 9\end{array}$ & $\begin{array}{l}\text { Traditional Shopping } \\
\text { Center }\end{array}$ \\
\hline Louis Vuitton & France & Bloor Street & Toronto & $\begin{array}{l}150 \text { Bloor St } \\
\text { W, Toronto, } \\
\text { ON }\end{array}$ & ON & $\begin{array}{l}\text { M5S } \\
2 \times 9\end{array}$ & Strip Mall \\
\hline Louis Vuitton & France & Burrand Street & Vancouver & $\begin{array}{l}730 \text { Burrard } \\
\text { Street }\end{array}$ & $B C$ & $\begin{array}{l}6 Z \\
2 V 6 \\
\end{array}$ & Ancillary \\
\hline Louis Vuitton & France & $\begin{array}{l}\text { The Fairmont Hotel } \\
\text { Vancouver }\end{array}$ & Vancouver & $\begin{array}{l}900 \text { West } \\
\text { Georgia } \\
\text { Street } \\
\text { Vancouver, } \\
\text { British } \\
\text { Columbia }\end{array}$ & $B C$ & $\begin{array}{l}\text { V6C } \\
2 W 6\end{array}$ & Ancillary \\
\hline Louis Vuitton & France & Yorkdale Shopping Centre & Toronto & $\begin{array}{l}3401 \text { Dufferin } \\
\text { Street Unit }\end{array}$ & ON & $\begin{array}{l}\text { M6A } \\
2 \mathrm{T9}\end{array}$ & $\begin{array}{l}\text { Traditional Shopping } \\
\text { Center }\end{array}$ \\
\hline
\end{tabular}




\begin{tabular}{|c|c|c|c|c|c|c|c|}
\hline Name & $\begin{array}{l}\text { Country } \\
\text { of Origin }\end{array}$ & Retail Location & CMA & Address & $\begin{array}{l}\text { Provin } \\
\text { ce }\end{array}$ & $\begin{array}{l}\text { Postal } \\
\text { Code }\end{array}$ & Retail Type \\
\hline & & & & $\begin{array}{l}\text { 217, Toronto, } \\
\text { ON }\end{array}$ & & & \\
\hline Massimo Dutti & Italy & Carrefour Laval & Montreal & $\begin{array}{l}3003 \\
\text { Boulevard Le } \\
\text { Carrefour, } \\
\text { Laval, QC } \\
\end{array}$ & QC & $\begin{array}{l}\mathrm{H7T} \\
1 \mathrm{C} 8\end{array}$ & $\begin{array}{l}\text { Traditional Shopping } \\
\text { Center }\end{array}$ \\
\hline Massimo Dutti & Italy & First Canada Place & Toronto & $\begin{array}{l}100 \text { King St. } \\
\text { West }\end{array}$ & ON & $\begin{array}{l}\text { M5X } \\
2 \mathrm{~A} 2\end{array}$ & Ancillary \\
\hline Massimo Dutti & Italy & Pacific Centre & Vancouver & $\begin{array}{l}701 \mathrm{~W} \\
\text { Georgia St, } \\
\text { Vancouver, } \\
\text { BC }\end{array}$ & $\mathrm{BC}$ & $\begin{array}{l}\text { V7Y } \\
1 G 5\end{array}$ & Major Downtown Mall \\
\hline Massimo Dutti & Italy & Rideau Centre & Ottawa - Gatineau & $\begin{array}{l}50 \text { Rideau St } \\
\# 300 \text {, Ottawa, } \\
\text { ON }\end{array}$ & ON & $\begin{array}{l}\text { K1N } \\
9 J 7\end{array}$ & Major Downtown Mall \\
\hline Massimo Dutti & Italy & Rockland Center & Montreal & $\begin{array}{l}2305 \text { Chemin } \\
\text { Rockland, } \\
\text { Montréal, QC }\end{array}$ & $Q C$ & $\begin{array}{l}\text { H3P } \\
3 E 9\end{array}$ & $\begin{array}{l}\text { Traditional Shopping } \\
\text { Center }\end{array}$ \\
\hline Massimo Dutti & Italy & Square One & Toronto & $\begin{array}{l}100 \text { City } \\
\text { Centre Dr, } \\
\text { Mississauga, } \\
\text { ON }\end{array}$ & ON & $\begin{array}{l}\text { L5B } \\
2 C 9\end{array}$ & $\begin{array}{l}\text { Traditional Shopping } \\
\text { Center }\end{array}$ \\
\hline Massimo Dutti & Italy & Toronto Eaton Centre & Toronto & $\begin{array}{l}220 \text { Yonge St, } \\
\text { Toronto, ON }\end{array}$ & ON & $\begin{array}{l}\text { M5B } \\
2 \mathrm{H} 1\end{array}$ & Major Downtown Mall \\
\hline Massimo Dutti & Italy & Yorkdale Shopping Centre & Toronto & $\begin{array}{l}3401 \text { Dufferin } \\
\text { Street Unit } \\
217 \text {, Toronto, } \\
\text { ON }\end{array}$ & ON & $\begin{array}{l}\text { M6A } \\
2 \mathrm{~T} 9\end{array}$ & $\begin{array}{l}\text { Traditional Shopping } \\
\text { Center }\end{array}$ \\
\hline Michael Kors & USA & Bloor Street & Toronto & $\begin{array}{l}131 \text { Bloor St } \\
\text { W \#106, } \\
\text { Toronto, ON }\end{array}$ & ON & $\begin{array}{l}\text { M5S } \\
\text { 1R1 }\end{array}$ & Strip Mall \\
\hline Michael Kors & USA & Carrefour Laval & Montreal & $\begin{array}{l}3003 \\
\text { Boulevard Le }\end{array}$ & QC & $\begin{array}{l}\mathrm{H7T} \\
1 \mathrm{C} 8\end{array}$ & $\begin{array}{l}\text { Traditional Shopping } \\
\text { Center }\end{array}$ \\
\hline
\end{tabular}




\begin{tabular}{|c|c|c|c|c|c|c|c|}
\hline Name & $\begin{array}{l}\text { Country } \\
\text { of Origin }\end{array}$ & Retail Location & CMA & Address & $\begin{array}{l}\text { Provin } \\
\text { ce }\end{array}$ & $\begin{array}{l}\text { Postal } \\
\text { Code }\end{array}$ & Retail Type \\
\hline & & & & $\begin{array}{l}\text { Carrefour, } \\
\text { Laval, QC }\end{array}$ & & & \\
\hline Michael Kors & USA & Chinook Centre & Calgary & $\begin{array}{l}6455 \\
\text { Macleod Trail } \\
\text { SW, Calgary, } \\
\text { AB }\end{array}$ & $A B$ & $\begin{array}{l}\mathrm{T} 2 \mathrm{H} \\
\text { OK8 }\end{array}$ & $\begin{array}{l}\text { Traditional Shopping } \\
\text { Center }\end{array}$ \\
\hline Michael Kors & USA & $\begin{array}{l}\text { CrossIron Mills Outlets } \\
\text { Mall }\end{array}$ & Calgary & $\begin{array}{l}261055 \\
\text { Crossiron } \\
\text { Blvd, Rocky } \\
\text { View No. 44, } \\
\text { AB } \\
\end{array}$ & $A B$ & $\begin{array}{l}\text { T4A } \\
\text { OG3 }\end{array}$ & Outlet Mall \\
\hline Michael Kors & USA & Don Mills & Toronto & $\begin{array}{l}16 \text { Aggie } \\
\text { Hogg } \\
\text { Gardens, } \\
\text { Toronto, ON } \\
\end{array}$ & ON & $\begin{array}{l}\text { M3C } \\
\text { OG7 }\end{array}$ & Strip Mall \\
\hline Michael Kors & USA & Fairview Pointe Claire & Montreal & $\begin{array}{l}6801 \text { Trans } \\
\text { Canada } \\
\text { Highway, } \\
\text { Pointe-Claire } \\
\end{array}$ & QC & $\begin{array}{l}\text { H9R } \\
5 J 2\end{array}$ & $\begin{array}{l}\text { Traditional Shopping } \\
\text { Center }\end{array}$ \\
\hline Michael Kors & USA & $\begin{array}{l}\text { Mapleview Shopping } \\
\text { Centre }\end{array}$ & Hamilton & $\begin{array}{l}900 \text { Maple } \\
\text { Ave, } \\
\text { Burlington, } \\
\text { ON }\end{array}$ & ON & L7S $2 J 8$ & $\begin{array}{l}\text { Traditional Shopping } \\
\text { Center }\end{array}$ \\
\hline Michael Kors & USA & $\begin{array}{l}\text { Markville Shopping } \\
\text { Centre }\end{array}$ & Toronto & $\begin{array}{l}5000 \text { Hwy 7, } \\
\text { Markham, ON }\end{array}$ & ON & $\begin{array}{l}\text { L3R } \\
4 \mathrm{M} 9\end{array}$ & $\begin{array}{l}\text { Traditional Shopping } \\
\text { Center }\end{array}$ \\
\hline MICHAEL KORS & USA & McArthurGlen Vancouver & Vancouver & $\begin{array}{l}7899 \\
\text { Templeton } \\
\text { Station Rd } \\
\# 1000, \\
\text { Richmond, BC }\end{array}$ & $\mathrm{BC}$ & $\begin{array}{l}\text { V7B } \\
\text { OB7 }\end{array}$ & Outlet Mall \\
\hline Michael Kors & USA & Metropolis at Metrotown & Vancouver & $\begin{array}{l}4700 \\
\text { Kingsway } \\
\# 604, \\
\text { Burnaby, BC }\end{array}$ & $\mathrm{BC}$ & $\begin{array}{l}\mathrm{V} 5 \mathrm{H} \\
4 \mathrm{~N} 2\end{array}$ & $\begin{array}{l}\text { Traditional Shopping } \\
\text { Center }\end{array}$ \\
\hline
\end{tabular}




\begin{tabular}{|c|c|c|c|c|c|c|c|}
\hline Name & $\begin{array}{l}\text { Country } \\
\text { of Origin }\end{array}$ & Retail Location & CMA & Address & $\begin{array}{l}\text { Provin } \\
\text { ce }\end{array}$ & $\begin{array}{l}\text { Postal } \\
\text { Code }\end{array}$ & Retail Type \\
\hline Michael Kors & USA & MIRABEL OUTLET & Montreal & $\begin{array}{l}19001 \\
\text { Chemin Notre } \\
\text { Dame, } \\
\text { Mirabel, QC }\end{array}$ & QC & J7J0T1 & Outlet Mall \\
\hline Michael Kors & USA & Oakridge Centre & Vancouver & $\begin{array}{l}650 \text { W 41st } \\
\text { Ave, } \\
\text { Vancouver, } \\
\text { BC }\end{array}$ & $\mathrm{BC}$ & $\begin{array}{l}\text { V5Z } \\
2 \mathrm{M} 9\end{array}$ & $\begin{array}{l}\text { Traditional Shopping } \\
\text { Center }\end{array}$ \\
\hline Michael Kors & USA & $\begin{array}{l}\text { Outlet Collection at } \\
\text { Niagara }\end{array}$ & St. Catharines - Niagara & $\begin{array}{l}300 \text { Taylor } \\
\text { Rd, Niagara- } \\
\text { on-the-Lake, } \\
\text { ON }\end{array}$ & ON & LOS 1J0 & Outlet Mall \\
\hline Michael Kors & USA & Pacific Centre & Vancouver & $\begin{array}{l}701 \mathrm{~W} \\
\text { Georgia St, } \\
\text { Vancouver, } \\
\text { BC }\end{array}$ & $\mathrm{BC}$ & $\begin{array}{l}\text { V7Y } \\
1 G 5\end{array}$ & Major Downtown Mall \\
\hline Michael Kors & USA & $\begin{array}{l}\text { Park Royal Shopping } \\
\text { Centre }\end{array}$ & Vancouver & $\begin{array}{l}\text { Park Royal } \\
925 \text { Main St. }\end{array}$ & $B C$ & $\begin{array}{l}\text { V7T } \\
2 \mathrm{~W} 4\end{array}$ & Strip Mall \\
\hline Michael Kors & USA & $\begin{array}{l}\text { Pearson Airport Terminal } \\
1\end{array}$ & Toronto & $\begin{array}{l}5675 \text { Silver } \\
\text { Dart Dr, } \\
\text { Mississauga, } \\
\text { ON }\end{array}$ & ON & $\begin{array}{l}\text { L5P } \\
1 B 2\end{array}$ & Airport \\
\hline Michael Kors & USA & Promenades St-Bruno & Montreal & $\begin{array}{l}1 \text { Boulevard } \\
\text { des } \\
\text { Promenades, } \\
\text { Saint-Bruno- } \\
\text { de- } \\
\text { Montarville, } \\
\text { QC }\end{array}$ & QC & J3V 5J5 & $\begin{array}{l}\text { Traditional Shopping } \\
\text { Center }\end{array}$ \\
\hline Michael Kors & USA & Richmond Centre & Vancouver & $\begin{array}{l}6551 \text { No } 3 \text { Rd, } \\
\text { Richmond, BC }\end{array}$ & $\mathrm{BC}$ & $\begin{array}{l}\text { V6Y } \\
2 B 6\end{array}$ & $\begin{array}{l}\text { Traditional Shopping } \\
\text { Center }\end{array}$ \\
\hline Michael Kors & USA & Rideau Centre & Ottawa - Gatineau & $\begin{array}{l}50 \text { Rideau St } \\
\# 300 \text {, Ottawa, } \\
\text { ON }\end{array}$ & ON & $\begin{array}{l}\text { K1N } \\
9 J 7\end{array}$ & Major Downtown Mall \\
\hline
\end{tabular}




\begin{tabular}{|c|c|c|c|c|c|c|c|}
\hline Name & $\begin{array}{l}\text { Country } \\
\text { of Origin }\end{array}$ & Retail Location & CMA & Address & $\begin{array}{l}\text { Provin } \\
\text { ce }\end{array}$ & $\begin{array}{l}\text { Postal } \\
\text { Code }\end{array}$ & Retail Type \\
\hline Michael Kors & USA & Rockland Center & Montreal & $\begin{array}{l}2305 \text { Chemin } \\
\text { Rockland, } \\
\text { Montréal, QC }\end{array}$ & QC & $\begin{array}{l}\text { H3P } \\
\text { 3E9 }\end{array}$ & $\begin{array}{l}\text { Traditional Shopping } \\
\text { Center }\end{array}$ \\
\hline Michael Kors & USA & Scarborough Town Centre & Toronto & $\begin{array}{l}300 \text { Borough } \\
\text { Dr, } \\
\text { Scarborough, } \\
\text { ON }\end{array}$ & $\mathrm{ON}$ & $\begin{array}{l}\text { M1P } \\
4 \text { P5 }\end{array}$ & $\begin{array}{l}\text { Traditional Shopping } \\
\text { Center }\end{array}$ \\
\hline Michael Kors & USA & Sherway Gardens & Toronto & $\begin{array}{l}25 \text { The West } \\
\text { Mall, } \\
\text { Etobicoke, } \\
\text { ON }\end{array}$ & ON & $\begin{array}{l}\text { M9C } \\
1 \mathrm{~B} 8\end{array}$ & $\begin{array}{l}\text { Traditional Shopping } \\
\text { Center }\end{array}$ \\
\hline Michael Kors & USA & Southcentre Mall & Calgary & $\begin{array}{l}100 \text { Anderson } \\
\text { Rd SE, } \\
\text { Calgary, AB }\end{array}$ & $A B$ & T2J 3V1 & $\begin{array}{l}\text { Traditional Shopping } \\
\text { Center }\end{array}$ \\
\hline Michael Kors & USA & Southgate Centre & Edmonton & $\begin{array}{l}5015111 \mathrm{St} \\
\mathrm{NW}, \\
\text { Edmonton, } \\
\mathrm{AB}\end{array}$ & $A B$ & $\begin{array}{l}\mathrm{T} 6 \mathrm{H} \\
4 \mathrm{M} 6\end{array}$ & $\begin{array}{l}\text { Traditional Shopping } \\
\text { Center }\end{array}$ \\
\hline Michael Kors & USA & Square One & Toronto & $\begin{array}{l}100 \text { City } \\
\text { Centre Dr, } \\
\text { Mississauga, } \\
\text { ON }\end{array}$ & ON & $\begin{array}{l}\text { L5B } \\
2 C 9\end{array}$ & $\begin{array}{l}\text { Traditional Shopping } \\
\text { Center }\end{array}$ \\
\hline Michael Kors & USA & Tanger Outlet Ottawa & Ottawa - Gatineau & $\begin{array}{l}8555 \\
\text { Campeau Dr, } \\
\text { Ottawa, ON }\end{array}$ & ON & $\begin{array}{l}\text { K2T } \\
\text { OK5 }\end{array}$ & Outlet Mall \\
\hline Michael Kors & USA & The Core & Calgary & $\begin{array}{l}3248 \text { Ave } \\
\text { SW, Calgary, } \\
A B\end{array}$ & $A B$ & $\begin{array}{l}\mathrm{T} 2 \mathrm{P} \\
2 \mathrm{Z2}\end{array}$ & Major Downtown Mall \\
\hline Michael Kors & USA & Toronto Eaton Centre & Toronto & $\begin{array}{l}220 \text { Yonge St, } \\
\text { Toronto, ON }\end{array}$ & ON & $\begin{array}{l}\text { M5B } \\
2 \mathrm{H} 1\end{array}$ & Major Downtown Mall \\
\hline Michael Kors & USA & Toronto Premium Outlet & Toronto & $\begin{array}{l}13850 \text { Steeles } \\
\text { Avenue W, } \\
\text { Halton Hills, } \\
\text { ON }\end{array}$ & $\mathrm{ON}$ & L7G 0J1 & Outlet Mall \\
\hline
\end{tabular}




\begin{tabular}{|c|c|c|c|c|c|c|c|}
\hline Name & $\begin{array}{l}\text { Country } \\
\text { of Origin }\end{array}$ & Retail Location & CMA & Address & $\begin{array}{l}\text { Provin } \\
\text { ce }\end{array}$ & $\begin{array}{l}\text { Postal } \\
\text { Code }\end{array}$ & Retail Type \\
\hline Michael Kors & USA & Upper Canada Mall & Toronto & $\begin{array}{l}17600 \text { Yonge } \\
\text { St, } \\
\text { Newmarket, } \\
\text { ON }\end{array}$ & ON & L3Y 4Z1 & $\begin{array}{l}\text { Traditional Shopping } \\
\text { Center }\end{array}$ \\
\hline Michael Kors & USA & Vaughan Mills & Toronto & $\begin{array}{l}1 \text { Bass Pro } \\
\text { Mills Dr, } \\
\text { Concord, ON }\end{array}$ & ON & $\begin{array}{l}\text { L4K } \\
5 W 4\end{array}$ & Outlet Mall \\
\hline Michael Kors & USA & West Edmonton Mall & Edmonton & $\begin{array}{l}8882170 \mathrm{St} \\
\mathrm{NW}, \\
\text { Edmonton, } \\
\mathrm{AB}\end{array}$ & $A B$ & T5T 4J2 & $\begin{array}{l}\text { Traditional Shopping } \\
\text { Center }\end{array}$ \\
\hline Michael Kors & USA & Yorkdale Shopping Centre & Toronto & $\begin{array}{l}3401 \text { Dufferin } \\
\text { Street Unit } \\
217 \text {, Toronto, } \\
\text { ON }\end{array}$ & ON & $\begin{array}{l}\text { M6A } \\
2 T 9\end{array}$ & $\begin{array}{l}\text { Traditional Shopping } \\
\text { Center }\end{array}$ \\
\hline Moncler & Italy & Yorkdale Shopping Centre & Toronto & $\begin{array}{l}3401 \text { Dufferin } \\
\text { Street Unit } \\
217 \text {, Toronto, } \\
\text { ON }\end{array}$ & ON & $\begin{array}{l}\text { M6A } \\
2 T 9\end{array}$ & $\begin{array}{l}\text { Traditional Shopping } \\
\text { Center }\end{array}$ \\
\hline Mulberry & UK & Bloor Street & Toronto & $\begin{array}{l}131 \text { Bloor } \\
\text { Street West, } \\
\text { Suite 103, } \\
\text { Toronto } \\
\end{array}$ & ON & $\begin{array}{l}\text { M5S } \\
\text { 1R1 }\end{array}$ & Strip Mall \\
\hline Mulberry & UK & Yorkdale Shopping Centre & Toronto & $\begin{array}{l}3401 \text { Dufferin } \\
\text { Street Unit } \\
217 \text {, Toronto, } \\
\text { ON }\end{array}$ & ON & $\begin{array}{l}\text { M6A } \\
2 T 9\end{array}$ & $\begin{array}{l}\text { Traditional Shopping } \\
\text { Center }\end{array}$ \\
\hline Nordstrom & USA & Chinook Centre & Calgary & $\begin{array}{l}6455 \\
\text { Macleod Trail } \\
\text { SW, Calgary, } \\
\text { AB }\end{array}$ & $A B$ & $\begin{array}{l}\mathrm{T} 2 \mathrm{H} \\
\text { OK8 }\end{array}$ & $\begin{array}{l}\text { Traditional Shopping } \\
\text { Center }\end{array}$ \\
\hline Nordstrom & USA & Pacific Centre & Vancouver & $\begin{array}{l}701 \mathrm{~W} \\
\text { Georgia St, } \\
\text { Vancouver, } \\
\text { BC }\end{array}$ & $\mathrm{BC}$ & $\begin{array}{l}\text { V7Y } \\
1 G 5\end{array}$ & Major Downtown Mall \\
\hline
\end{tabular}




\begin{tabular}{|c|c|c|c|c|c|c|c|}
\hline Name & $\begin{array}{l}\text { Country } \\
\text { of Origin }\end{array}$ & Retail Location & CMA & Address & $\begin{array}{l}\text { Provin } \\
\text { ce }\end{array}$ & $\begin{array}{l}\text { Postal } \\
\text { Code }\end{array}$ & Retail Type \\
\hline Nordstrom & USA & Rideau Centre & Ottawa - Gatineau & $\begin{array}{l}50 \text { Rideau St } \\
\# 300, \text { Ottawa, } \\
\text { ON }\end{array}$ & ON & $\begin{array}{l}\text { K1N } \\
9 J 7\end{array}$ & Major Downtown Mall \\
\hline Nordstrom & USA & Sherway Gardens & Toronto & $\begin{array}{l}25 \text { The West } \\
\text { Mall, } \\
\text { Etobicoke, } \\
\text { ON }\end{array}$ & ON & $\begin{array}{l}\text { M9C } \\
1 \mathrm{~B} 8\end{array}$ & $\begin{array}{l}\text { Traditional Shopping } \\
\text { Center }\end{array}$ \\
\hline Nordstrom & USA & Toronto Eaton Centre & Toronto & $\begin{array}{l}220 \text { Yonge St, } \\
\text { Toronto, ON }\end{array}$ & ON & $\begin{array}{l}\mathrm{M} 5 \mathrm{~B} \\
2 \mathrm{H} 1\end{array}$ & Major Downtown Mall \\
\hline Nordstrom & USA & Yorkdale Shopping Centre & Toronto & $\begin{array}{l}3401 \text { Dufferin } \\
\text { Street Unit } \\
217 \text {, Toronto, } \\
\text { ON }\end{array}$ & ON & $\begin{array}{l}\text { M6A } \\
2 \mathrm{~T} 9\end{array}$ & $\begin{array}{l}\text { Traditional Shopping } \\
\text { Center }\end{array}$ \\
\hline Prada & Italy & Yorkville & Toronto & $\begin{array}{l}131 \text { Bloor St } \\
\text { W, Toronto, } \\
\text { ON }\end{array}$ & ON & $\begin{array}{l}\text { M5S } \\
1 \mathrm{R} 1\end{array}$ & Strip Mall \\
\hline Reiss & UK & Sherway Gardens & Toronto & $\begin{array}{l}25 \text { The West } \\
\text { Mall, } \\
\text { Etobicoke, } \\
\text { ON }\end{array}$ & $\mathrm{ON}$ & $\begin{array}{l}\text { M9C } \\
1 \mathrm{~B} 8\end{array}$ & $\begin{array}{l}\text { Traditional Shopping } \\
\text { Center }\end{array}$ \\
\hline Reiss & UK & Toronto Eaton Centre & Toronto & $\begin{array}{l}220 \text { Yonge St, } \\
\text { Toronto, ON }\end{array}$ & ON & $\begin{array}{l}\text { M5B } \\
2 \mathrm{H} 1\end{array}$ & Major Downtown Mall \\
\hline Reiss & UK & Yorkdale Shopping Centre & Toronto & $\begin{array}{l}3401 \text { Dufferin } \\
\text { Street Unit } \\
217 \text {, Toronto, } \\
\text { ON }\end{array}$ & ON & $\begin{array}{l}\text { M6A } \\
\text { 2T9 }\end{array}$ & $\begin{array}{l}\text { Traditional Shopping } \\
\text { Center }\end{array}$ \\
\hline Saks Fifth Avenue & USA & Sherway Gardens & Toronto & $\begin{array}{l}25 \text { The West } \\
\text { Mall, } \\
\text { Etobicoke, } \\
\text { ON }\end{array}$ & ON & $\begin{array}{l}\text { M9C } \\
1 \mathrm{~B} 8\end{array}$ & $\begin{array}{l}\text { Traditional Shopping } \\
\text { Center }\end{array}$ \\
\hline Saks Fifth Avenue & USA & Toronto Eaton Centre & Toronto & $\begin{array}{l}220 \text { Yonge St, } \\
\text { Toronto, ON }\end{array}$ & ON & $\begin{array}{l}\text { M5B } \\
2 \mathrm{H} 1\end{array}$ & Major Downtown Mall \\
\hline $\begin{array}{l}\text { Saks Fifth Avenue } \\
\text { OFF 5TH }\end{array}$ & USA & Sherway Gardens & Toronto & $\begin{array}{l}1950 \text { The } \\
\text { Queensway, }\end{array}$ & ON & $\begin{array}{l}\mathrm{M} 9 \mathrm{C} \\
5 \mathrm{H} 5\end{array}$ & Strip Mall \\
\hline
\end{tabular}




\begin{tabular}{|c|c|c|c|c|c|c|c|}
\hline Name & $\begin{array}{l}\text { Country } \\
\text { of Origin }\end{array}$ & Retail Location & CMA & Address & $\begin{array}{l}\text { Provin } \\
\text { ce }\end{array}$ & $\begin{array}{l}\text { Postal } \\
\text { Code }\end{array}$ & Retail Type \\
\hline & & & & $\begin{array}{l}\text { Etobicoke, } \\
\text { ON }\end{array}$ & & & \\
\hline $\begin{array}{l}\text { Saks Fifth Avenue } \\
\text { OFF 5TH }\end{array}$ & USA & Toronto Premium Outlet & Toronto & $\begin{array}{l}13850 \text { Steeles } \\
\text { Avenue W, } \\
\text { Halton Hills, } \\
\text { ON }\end{array}$ & ON & L7G 0J1 & Outlet Mall \\
\hline $\begin{array}{l}\text { Saks Fifth Avenue } \\
\text { OFF 5TH }\end{array}$ & USA & Vaughan Mills & Toronto & $\begin{array}{l}1 \text { Bass Pro } \\
\text { Mills Dr, } \\
\text { Concord, ON }\end{array}$ & ON & $\begin{array}{l}\text { L4K } \\
5 W 4\end{array}$ & Outlet Mall \\
\hline Salvatore Ferragamo & Italy & MIRABEL OUTLET & Montreal & $\begin{array}{l}19001 \\
\text { Chemin Notre } \\
\text { Dame, } \\
\text { Mirabel, QC }\end{array}$ & QC & J7J0T1 & Outlet Mall \\
\hline Salvatore Ferragamo & Italy & $\begin{array}{l}\text { Pearson Airport Terminal } \\
1\end{array}$ & Toronto & $\begin{array}{l}5675 \text { Silver } \\
\text { Dart Dr, } \\
\text { Mississauga, } \\
\text { ON } \\
\end{array}$ & ON & $\begin{array}{l}\text { L5P } \\
1 B 2\end{array}$ & Airport \\
\hline Salvatore Ferragamo & Italy & $\begin{array}{l}\text { Pearson Airport Terminal } \\
1\end{array}$ & Toronto & $\begin{array}{l}5675 \text { Silver } \\
\text { Dart Dr, } \\
\text { Mississauga, } \\
\text { ON }\end{array}$ & ON & $\begin{array}{l}\text { L5P } \\
1 \mathrm{~B} 2\end{array}$ & Airport \\
\hline Salvatore Ferragamo & Italy & Robson Street & Vancouver & $\begin{array}{l}918 \text { Robson } \\
\text { St, } \\
\text { Vancouver, } \\
\text { BC }\end{array}$ & $\mathrm{BC}$ & $\begin{array}{l}\text { V6Z } \\
2 E 7\end{array}$ & Strip Mall \\
\hline Salvatore Ferragamo & Italy & Square One & Toronto & $\begin{array}{l}100 \text { City } \\
\text { Centre Dr, } \\
\text { Mississauga, } \\
\text { ON } \\
\end{array}$ & ON & $\begin{array}{l}5 B \\
2 C 9\end{array}$ & $\begin{array}{l}\text { Traditional Shopping } \\
\text { Center }\end{array}$ \\
\hline Salvatore Ferragamo & Italy & $\begin{array}{l}\text { Vancouver International } \\
\text { Airport }\end{array}$ & Vancouver & $\begin{array}{l}3211 \text { Grant } \\
\text { McConachie } \\
\text { Way, } \\
\text { Richmond, BC }\end{array}$ & $\mathrm{BC}$ & $\begin{array}{l}\text { V7B } \\
\text { OA4 }\end{array}$ & Airport \\
\hline Salvatore Ferragamo & Italy & Yorkdale Shopping Centre & Toronto & $\begin{array}{l}3401 \text { Dufferin } \\
\text { Street Unit }\end{array}$ & ON & $\begin{array}{l}\text { M6A } \\
2 \mathrm{~T} 9\end{array}$ & $\begin{array}{l}\text { Traditional Shopping } \\
\text { Center }\end{array}$ \\
\hline
\end{tabular}




\begin{tabular}{|c|c|c|c|c|c|c|c|}
\hline Name & $\begin{array}{l}\text { Country } \\
\text { of Origin }\end{array}$ & Retail Location & CMA & Address & $\begin{array}{l}\text { Provin } \\
\text { ce }\end{array}$ & $\begin{array}{l}\text { Postal } \\
\text { Code }\end{array}$ & Retail Type \\
\hline & & & & $\begin{array}{l}\text { 217, Toronto, } \\
\text { ON }\end{array}$ & & & \\
\hline Scotch and Soda & $\begin{array}{l}\text { Netherlan } \\
\text { ds }\end{array}$ & Carrefour Laval & Montreal & $\begin{array}{l}3003 \\
\text { Boulevard Le } \\
\text { Carrefour, } \\
\text { Laval, QC }\end{array}$ & QC & $\begin{array}{l}\mathrm{H7T} \\
1 \mathrm{C} 8\end{array}$ & $\begin{array}{l}\text { Traditional Shopping } \\
\text { Center }\end{array}$ \\
\hline Scotch and Soda & $\begin{array}{l}\text { Netherlan } \\
\text { ds }\end{array}$ & Richmond Centre & Vancouver & $\begin{array}{l}6551 \text { No } 3 \text { Rd, } \\
\text { Richmond, BC }\end{array}$ & $B C$ & $\begin{array}{l}6 \mathrm{Y} \\
2 \mathrm{~B} 6\end{array}$ & $\begin{array}{l}\text { Traditional Shopping } \\
\text { Center }\end{array}$ \\
\hline Scotch and Soda & $\begin{array}{l}\text { Netherlan } \\
\text { ds }\end{array}$ & Toronto Eaton Centre & Toronto & $\begin{array}{l}220 \text { Yonge St, } \\
\text { Toronto, ON }\end{array}$ & ON & $\begin{array}{l}\text { M5B } \\
2 \mathrm{H} 1\end{array}$ & Major Downtown Mall \\
\hline Scotch and Soda & $\begin{array}{l}\text { Netherlan } \\
\text { ds }\end{array}$ & West Edmonton Mall & Edmonton & $\begin{array}{l}8882170 \mathrm{St} \\
\mathrm{NW}, \\
\text { Edmonton, } \\
A B\end{array}$ & $A B$ & T5T 4J2 & $\begin{array}{l}\text { Traditional Shopping } \\
\text { Center }\end{array}$ \\
\hline Stuart Weitzman & USA & Bayview Village & Toronto & $\begin{array}{l}2901 \text { Bayview } \\
\text { Ave, Toronto, } \\
\text { ON }\end{array}$ & ON & $\begin{array}{l}\mathrm{M} 2 \mathrm{~K} \\
1 \mathrm{E} 9\end{array}$ & $\begin{array}{l}\text { Traditional Shopping } \\
\text { Center }\end{array}$ \\
\hline Stuart Weitzman & USA & Bloor Street & Toronto & $\begin{array}{l}151 \text { Bloor } \\
\text { Street West, } \\
\text { Toronto, ON }\end{array}$ & ON & $\begin{array}{l}\text { M5S } \\
1 S 4\end{array}$ & Strip Mall \\
\hline Stuart Weitzman & USA & Carrefour Laval & Montreal & $\begin{array}{l}3003 \\
\text { Boulevard Le } \\
\text { Carrefour, } \\
\text { Laval, QC }\end{array}$ & QC & $\begin{array}{l}\mathrm{H7T} \\
1 \mathrm{C} 8\end{array}$ & $\begin{array}{l}\text { Traditional Shopping } \\
\text { Center }\end{array}$ \\
\hline Stuart Weitzman & USA & Chinook Centre & Calgary & $\begin{array}{l}6455 \\
\text { Macleod Trail } \\
\text { SW, Calgary, } \\
\text { AB }\end{array}$ & $A B$ & $\begin{array}{l}\text { T2H } \\
\text { OK8 }\end{array}$ & $\begin{array}{l}\text { Traditional Shopping } \\
\text { Center }\end{array}$ \\
\hline Stuart Weitzman & USA & Oakridge Centre & Vancouver & $\begin{array}{l}\text { 650 W. 41st } \\
\text { Avenue, } \\
\text { Vancouver, } \\
\text { British } \\
\text { Columbia }\end{array}$ & $\mathrm{BC}$ & $\begin{array}{l}\text { V5Z } \\
2 \mathrm{M} 9\end{array}$ & Major Downtown Mall \\
\hline Stuart Weitzman & USA & Pacific Centre & Vancouver & $\begin{array}{l}701 \mathrm{~W} \\
\text { Georgia St, }\end{array}$ & $\mathrm{BC}$ & $\begin{array}{l}\text { V7Y } \\
1 G 5\end{array}$ & Major Downtown Mall \\
\hline
\end{tabular}




\begin{tabular}{|c|c|c|c|c|c|c|c|}
\hline Name & $\begin{array}{l}\text { Country } \\
\text { of Origin }\end{array}$ & Retail Location & CMA & Address & $\begin{array}{l}\text { Provin } \\
\text { ce }\end{array}$ & $\begin{array}{l}\text { Postal } \\
\text { Code }\end{array}$ & Retail Type \\
\hline & & & & $\begin{array}{l}\text { Vancouver, } \\
\text { BC }\end{array}$ & & & \\
\hline Stuart Weitzman & USA & $\begin{array}{l}\text { Park Royal Shopping } \\
\text { Centre }\end{array}$ & Vancouver & $\begin{array}{l}\text { Park Royal } \\
925 \text { Main St. }\end{array}$ & $B C$ & $\begin{array}{l}\text { V7T } \\
2 \mathrm{~W} 4\end{array}$ & Strip Mall \\
\hline Stuart Weitzman & USA & Rideau Centre & Ottawa - Gatineau & $\begin{array}{l}50 \text { Rideau St } \\
\# 300, \text { Ottawa, } \\
\text { ON }\end{array}$ & ON & $\begin{array}{l}\text { K1N } \\
9 J 7\end{array}$ & Major Downtown Mall \\
\hline Stuart Weitzman & USA & Rockland Center & Montreal & $\begin{array}{l}2305 \text { Chemin } \\
\text { Rockland, } \\
\text { Montréal, QC }\end{array}$ & $Q C$ & $\begin{array}{l}\text { H3P } \\
3 E 9\end{array}$ & $\begin{array}{l}\text { Traditional Shopping } \\
\text { Center }\end{array}$ \\
\hline Stuart Weitzman & USA & Sherway Gardens & Toronto & $\begin{array}{l}25 \text { The West } \\
\text { Mall, } \\
\text { Etobicoke, } \\
\text { ON }\end{array}$ & ON & $\begin{array}{l}\mathrm{M} 9 \mathrm{C} \\
1 \mathrm{~B} 8\end{array}$ & $\begin{array}{l}\text { Traditional Shopping } \\
\text { Center }\end{array}$ \\
\hline Stuart Weitzman & USA & Square One & Toronto & $\begin{array}{l}100 \text { City } \\
\text { Centre Dr, } \\
\text { Mississauga, } \\
\text { ON }\end{array}$ & ON & $\begin{array}{l}\text { L5B } \\
2 C 9\end{array}$ & $\begin{array}{l}\text { Traditional Shopping } \\
\text { Center }\end{array}$ \\
\hline Stuart Weitzman & USA & Toronto Eaton Centre & Toronto & $\begin{array}{l}220 \text { Yonge St, } \\
\text { Toronto, ON }\end{array}$ & ON & $\begin{array}{l}\text { M5B } \\
2 \mathrm{H} 1\end{array}$ & Major Downtown Mall \\
\hline Stuart Weitzman & USA & West Edmonton Mall & Edmonton & $\begin{array}{l}8882170 \mathrm{St} \\
\mathrm{NW} \\
\text { Edmonton, } \\
\mathrm{AB}\end{array}$ & $A B$ & T5T 4J2 & $\begin{array}{l}\text { Traditional Shopping } \\
\text { Center }\end{array}$ \\
\hline Stuart Weitzman & USA & Yorkdale Shopping Centre & Toronto & $\begin{array}{l}3401 \text { Dufferin } \\
\text { Street Unit } \\
217 \text {, Toronto, } \\
\text { ON }\end{array}$ & ON & $\begin{array}{l}\text { M6A } \\
2 \mathrm{~T} 9\end{array}$ & $\begin{array}{l}\text { Traditional Shopping } \\
\text { Center }\end{array}$ \\
\hline Ted Baker & UK & Chinook Centre & Calgary & $\begin{array}{l}6455 \\
\text { Macleod Trail } \\
\text { SW, Calgary, } \\
\text { AB }\end{array}$ & $A B$ & $\begin{array}{l}\text { T2H } \\
\text { OK8 }\end{array}$ & $\begin{array}{l}\text { Traditional Shopping } \\
\text { Center }\end{array}$ \\
\hline Ted Baker & UK & McArthurGlen Vancouver & Vancouver & $\begin{array}{l}7899 \\
\text { Templeton } \\
\text { Station Rd }\end{array}$ & $B C$ & $\begin{array}{l}\text { V7B } \\
\text { OB7 }\end{array}$ & Outlet Mall \\
\hline
\end{tabular}




\begin{tabular}{|c|c|c|c|c|c|c|c|}
\hline Name & $\begin{array}{l}\text { Country } \\
\text { of Origin }\end{array}$ & Retail Location & CMA & Address & $\begin{array}{l}\text { Provin } \\
\text { ce }\end{array}$ & $\begin{array}{l}\text { Postal } \\
\text { Code }\end{array}$ & Retail Type \\
\hline & & & & $\begin{array}{l}\# 1000, \\
\text { Richmond, BC }\end{array}$ & & & \\
\hline Ted Baker & UK & Pacific Centre & Vancouver & $\begin{array}{l}701 \mathrm{~W} \\
\text { Georgia St, } \\
\text { Vancouver, } \\
\text { BC }\end{array}$ & $\mathrm{BC}$ & $\begin{array}{l}\text { V7Y } \\
1 G 5\end{array}$ & Major Downtown Mall \\
\hline Ted Baker & UK & Rideau Centre & Ottawa - Gatineau & $\begin{array}{l}50 \text { Rideau St } \\
\# 300, \text { Ottawa, } \\
\text { ON }\end{array}$ & ON & $\begin{array}{l}\text { K1N } \\
9 J 7\end{array}$ & Major Downtown Mall \\
\hline Ted Baker & UK & Sherway Gardens & Toronto & $\begin{array}{l}25 \text { The West } \\
\text { Mall, } \\
\text { Etobicoke, } \\
\text { ON }\end{array}$ & ON & $\begin{array}{l}\text { M9C } \\
1 \mathrm{~B} 8\end{array}$ & $\begin{array}{l}\text { Traditional Shopping } \\
\text { Center }\end{array}$ \\
\hline Ted Baker & UK & Toronto Eaton Centre & Toronto & $\begin{array}{l}220 \text { Yonge St, } \\
\text { Toronto, ON }\end{array}$ & ON & $\begin{array}{l}\text { M5B } \\
2 \mathrm{H} 1\end{array}$ & Major Downtown Mall \\
\hline Ted Baker & UK & Toronto Premium Outlet & Toronto & $\begin{array}{l}13850 \text { Steeles } \\
\text { Avenue W, } \\
\text { Halton Hills, } \\
\text { ON }\end{array}$ & ON & L7G 0J1 & Outlet Mall \\
\hline Ted Baker & UK & Yorkdale Shopping Centre & Toronto & $\begin{array}{l}3401 \text { Dufferin } \\
\text { Street Unit } \\
217 \text {, Toronto, } \\
\text { ON }\end{array}$ & ON & $\begin{array}{l}\text { M6A } \\
2 T 9\end{array}$ & $\begin{array}{l}\text { Traditional Shopping } \\
\text { Center }\end{array}$ \\
\hline The Kooples & UK & Toronto Premium Outlet & Toronto & $\begin{array}{l}13850 \text { Steeles } \\
\text { Avenue W, } \\
\text { Halton Hills, } \\
\text { ON }\end{array}$ & ON & L7G 0J1 & Outlet Mall \\
\hline Tiffany and Co. & USA & Bloor Street & Toronto & $\begin{array}{l}150 \text { Bloor } \\
\text { Street West, } \\
\text { Toronto, } \\
\text { Ontario }\end{array}$ & ON & $\begin{array}{l}\text { M5S } \\
2 \times 9\end{array}$ & Strip Mall \\
\hline Tiffany and Co. & USA & Burrand Street & Vancouver & $\begin{array}{l}723 \text { Burrard } \\
\text { Street, } \\
\text { Vancouver, }\end{array}$ & $\mathrm{BC}$ & $\begin{array}{l}\text { V6Z } \\
2 \mathrm{P} 1\end{array}$ & Strip Mall \\
\hline
\end{tabular}




\begin{tabular}{|c|c|c|c|c|c|c|c|}
\hline Name & $\begin{array}{l}\text { Country } \\
\text { of Origin }\end{array}$ & Retail Location & CMA & Address & $\begin{array}{l}\text { Provin } \\
\text { ce }\end{array}$ & $\begin{array}{l}\text { Postal } \\
\text { Code }\end{array}$ & Retail Type \\
\hline & & & & $\begin{array}{l}\text { British } \\
\text { Columbia }\end{array}$ & & & \\
\hline Tiffany and Co. & USA & Chinook Centre & Calgary & $\begin{array}{l}6455 \\
\text { Macleod Trail } \\
\text { SW, Calgary, } \\
\text { AB }\end{array}$ & $A B$ & $\begin{array}{l}\mathrm{T} 2 \mathrm{H} \\
\text { OK8 }\end{array}$ & $\begin{array}{l}\text { Traditional Shopping } \\
\text { Center }\end{array}$ \\
\hline Tiffany and Co. & USA & Oakridge Centre & Vancouver & $\begin{array}{l}650 \text { W. 41st } \\
\text { Avenue, } \\
\text { Vancouver, } \\
\text { British } \\
\text { Columbia } \\
\end{array}$ & $\mathrm{BC}$ & $\begin{array}{l}\text { V5Z } \\
2 \mathrm{M} 9\end{array}$ & Major Downtown Mall \\
\hline Tiffany and Co. & USA & Rideau Centre & Ottawa - Gatineau & $\begin{array}{l}50 \text { Rideau St } \\
\# 300, \text { Ottawa, } \\
\text { ON }\end{array}$ & ON & $\begin{array}{l}\text { K1N } \\
9 J 7\end{array}$ & Major Downtown Mall \\
\hline Tiffany and Co. & USA & $\begin{array}{l}\text { Rue Sainte-Catherine } \\
\text { Ouest }\end{array}$ & Montreal & $\begin{array}{l}1290 \text { Rue } \\
\text { Sherbrooke } \\
\text { Ouest, } \\
\text { Montreal, } \\
\text { Quebec }\end{array}$ & QC & $\begin{array}{l}\mathrm{H} 3 \mathrm{G} \\
1 \mathrm{H} 5\end{array}$ & Strip Mall \\
\hline Tiffany and Co. & USA & Sherway Gardens & Toronto & $\begin{array}{l}25 \text { The West } \\
\text { Mall, } \\
\text { Etobicoke, } \\
\text { ON }\end{array}$ & ON & $\begin{array}{l}\text { M9C } \\
1 \mathrm{~B} 8\end{array}$ & $\begin{array}{l}\text { Traditional Shopping } \\
\text { Center }\end{array}$ \\
\hline Tiffany and Co. & USA & West Edmonton Mall & Edmonton & $\begin{array}{l}8882170 \mathrm{St} \\
\mathrm{NW} \\
\text { Edmonton, } \\
\mathrm{AB}\end{array}$ & $A B$ & T5T 4J2 & $\begin{array}{l}\text { Traditional Shopping } \\
\text { Center }\end{array}$ \\
\hline Tiffany and Co. & USA & Yorkdale Shopping Centre & Toronto & $\begin{array}{l}3401 \text { Dufferin } \\
\text { Street Unit } \\
217 \text {, Toronto, } \\
\text { ON }\end{array}$ & ON & $\begin{array}{l}\text { M6A } \\
2 \mathrm{~T} 9\end{array}$ & $\begin{array}{l}\text { Traditional Shopping } \\
\text { Center }\end{array}$ \\
\hline Tory Burch & USA & Alberni Street & Vancouver & $\begin{array}{l}1902 \text { Alberni } \\
\text { St., } \\
\text { Vanvouver, } \\
\text { BC }\end{array}$ & $\mathrm{BC}$ & $\begin{array}{l}\text { V6E } \\
1 \mathrm{A3}\end{array}$ & Strip Mall \\
\hline
\end{tabular}




\begin{tabular}{|c|c|c|c|c|c|c|c|}
\hline Name & $\begin{array}{l}\text { Country } \\
\text { of Origin }\end{array}$ & Retail Location & CMA & Address & $\begin{array}{l}\text { Provin } \\
\text { ce }\end{array}$ & $\begin{array}{l}\text { Postal } \\
\text { Code }\end{array}$ & Retail Type \\
\hline Tory Burch & USA & Chinook Centre & Calgary & $\begin{array}{l}6455 \\
\text { Macleod Trail } \\
\text { SW, Calgary, } \\
\text { AB }\end{array}$ & $A B$ & $\begin{array}{l}\text { T2H } \\
\text { OK8 }\end{array}$ & $\begin{array}{l}\text { Traditional Shopping } \\
\text { Center }\end{array}$ \\
\hline Tory Burch & USA & Sherway Gardens & Toronto & $\begin{array}{l}25 \text { The West } \\
\text { Mall, } \\
\text { Etobicoke, } \\
\text { ON }\end{array}$ & ON & $\begin{array}{l}\mathrm{M} 9 \mathrm{C} \\
1 \mathrm{~B} 8\end{array}$ & $\begin{array}{l}\text { Traditional Shopping } \\
\text { Center }\end{array}$ \\
\hline Tory Burch & USA & Toronto Premium Outlet & Toronto & $\begin{array}{l}13850 \text { Steeles } \\
\text { Avenue W, } \\
\text { Halton Hills, } \\
\text { ON }\end{array}$ & ON & L7G 0J1 & Outlet Mall \\
\hline Tory Burch & USA & Yorkdale Shopping Centre & Toronto & $\begin{array}{l}3401 \text { Dufferin } \\
\text { Street Unit } \\
217 \text {, Toronto, } \\
\text { ON }\end{array}$ & ON & $\begin{array}{l}\text { M6A } \\
2 T 9\end{array}$ & $\begin{array}{l}\text { Traditional Shopping } \\
\text { Center }\end{array}$ \\
\hline Tumi & USA & Chinook Centre & Calgary & $\begin{array}{l}6455 \\
\text { Macleod Trail } \\
\text { SW, Calgary, } \\
\text { AB }\end{array}$ & $A B$ & $\begin{array}{l}\text { T2H } \\
\text { OK8 }\end{array}$ & $\begin{array}{l}\text { Traditional Shopping } \\
\text { Center }\end{array}$ \\
\hline Tumi & USA & McArthurGlen Vancouver & Vancouver & $\begin{array}{l}7899 \\
\text { Templeton } \\
\text { Station Rd } \\
\# 1000, \\
\text { Richmond, BC }\end{array}$ & $\mathrm{BC}$ & $\begin{array}{l}\text { V7B } \\
\text { OB7 }\end{array}$ & Outlet Mall \\
\hline Tumi & USA & $\begin{array}{l}\text { Outlet Collection at } \\
\text { Niagara }\end{array}$ & St. Catharines - Niagara & $\begin{array}{l}300 \text { Taylor } \\
\text { Rd, Niagara- } \\
\text { on-the-Lake, } \\
\text { ON }\end{array}$ & ON & LOS 1JO & Outlet Mall \\
\hline Tumi & USA & Pacific Centre & Vancouver & $\begin{array}{l}701 \mathrm{~W} \\
\text { Georgia St, } \\
\text { Vancouver, } \\
\text { BC }\end{array}$ & $\mathrm{BC}$ & $\begin{array}{l}\text { V7Y } \\
1 G 5\end{array}$ & Major Downtown Mall \\
\hline Tumi & USA & $\begin{array}{l}\text { Pearson Airport Terminal } \\
1\end{array}$ & Toronto & $\begin{array}{l}5675 \text { Silver } \\
\text { Dart Dr, }\end{array}$ & ON & $\begin{array}{l}\text { L5P } \\
1 \mathrm{~B} 2\end{array}$ & Airport \\
\hline
\end{tabular}




\begin{tabular}{|c|c|c|c|c|c|c|c|}
\hline Name & $\begin{array}{l}\text { Country } \\
\text { of Origin }\end{array}$ & Retail Location & CMA & Address & $\begin{array}{l}\text { Provin } \\
\text { ce }\end{array}$ & $\begin{array}{l}\text { Postal } \\
\text { Code }\end{array}$ & Retail Type \\
\hline & & & & $\begin{array}{l}\text { Mississauga, } \\
\text { ON }\end{array}$ & & & \\
\hline Tumi & USA & Rideau Centre & Ottawa - Gatineau & $\begin{array}{l}50 \text { Rideau St } \\
\# 300, \text { Ottawa, } \\
\text { ON }\end{array}$ & ON & $\begin{array}{l}\text { K1N } \\
9 J 7\end{array}$ & Major Downtown Mall \\
\hline Tumi & USA & Royal Bank Plaza & Toronto & $\begin{array}{l}200 \text { Bay St, } \\
\text { Toronto, ON }\end{array}$ & ON & $\begin{array}{l}\text { M5J } \\
2 \mathrm{~J} 2\end{array}$ & Ancillary \\
\hline Tumi & USA & Sherway Gardens & Toronto & $\begin{array}{l}25 \text { The West } \\
\text { Mall, } \\
\text { Etobicoke, } \\
\text { ON }\end{array}$ & ON & $\begin{array}{l}\text { M9C } \\
1 \mathrm{~B} 8\end{array}$ & $\begin{array}{l}\text { Traditional Shopping } \\
\text { Center }\end{array}$ \\
\hline Tumi & USA & Square One & Toronto & $\begin{array}{l}100 \text { City } \\
\text { Centre Dr, } \\
\text { Mississauga, } \\
\text { ON }\end{array}$ & ON & $\begin{array}{l}\text { L5B } \\
2 C 9\end{array}$ & $\begin{array}{l}\text { Traditional Shopping } \\
\text { Center }\end{array}$ \\
\hline Tumi & USA & Toronto Eaton Centre & Toronto & $\begin{array}{l}220 \text { Yonge St, } \\
\text { Toronto, ON }\end{array}$ & ON & $\begin{array}{l}\text { M5B } \\
2 \mathrm{H} 1\end{array}$ & Major Downtown Mall \\
\hline Tumi & USA & Toronto Premium Outlet & Toronto & $\begin{array}{l}13850 \text { Steeles } \\
\text { Avenue W, } \\
\text { Halton Hills, } \\
\text { ON }\end{array}$ & ON & L7G 0J1 & Outlet Mall \\
\hline Tumi & USA & Vaughan Mills & Toronto & $\begin{array}{l}1 \text { Bass Pro } \\
\text { Mills Dr, } \\
\text { Concord, ON }\end{array}$ & ON & $\begin{array}{l}4 K \\
5 W 4\end{array}$ & Outlet Mall \\
\hline Tumi & USA & West Edmonton Mall & Edmonton & $\begin{array}{l}8882170 \mathrm{St} \\
\mathrm{NW} \\
\text { Edmonton, } \\
\mathrm{AB}\end{array}$ & $A B$ & T5T 4J2 & $\begin{array}{l}\text { Traditional Shopping } \\
\text { Center }\end{array}$ \\
\hline Tumi & USA & Yorkdale Shopping Centre & Toronto & $\begin{array}{l}3401 \text { Dufferin } \\
\text { Street Unit } \\
217, \text { Toronto, } \\
\text { ON }\end{array}$ & ON & $\begin{array}{l}\text { M6A } \\
2 \mathrm{~T} 9\end{array}$ & $\begin{array}{l}\text { Traditional Shopping } \\
\text { Center }\end{array}$ \\
\hline Versace & Italy & Thurlow Street & Vancouver & $\begin{array}{l}747 \text { Thurlow } \\
\text { Street,Vancou } \\
\text { ver }\end{array}$ & $\mathrm{BC}$ & $\begin{array}{l}\text { V6E } \\
1 \mathrm{~V} 8\end{array}$ & Strip Mall \\
\hline
\end{tabular}




\begin{tabular}{|c|c|c|c|c|c|c|c|}
\hline Name & $\begin{array}{l}\text { Country } \\
\text { of Origin }\end{array}$ & Retail Location & CMA & Address & $\begin{array}{l}\text { Provin } \\
\text { ce }\end{array}$ & $\begin{array}{l}\text { Postal } \\
\text { Code }\end{array}$ & Retail Type \\
\hline Versace & Italy & Yorkdale Shopping Centre & Toronto & $\begin{array}{l}3401 \text { Dufferin } \\
\text { Street Unit } \\
217 \text {, Toronto, } \\
\text { ON }\end{array}$ & ON & $\begin{array}{l}\text { M6A } \\
2 T 9\end{array}$ & $\begin{array}{l}\text { Traditional Shopping } \\
\text { Center }\end{array}$ \\
\hline Versace Home & Italy & Cordova Street & Vancouver & $\begin{array}{l}310 \mathrm{~W} \\
\text { Cordova St., } \\
\text { Vancouver }\end{array}$ & $\mathrm{BC}$ & $\begin{array}{l}\text { V6B } \\
1 E 8\end{array}$ & Strip Mall \\
\hline Vince Camuto & USA & Sherway Gardens & Toronto & $\begin{array}{l}25 \text { The West } \\
\text { Mall, } \\
\text { Etobicoke, } \\
\text { ON }\end{array}$ & ON & $\begin{array}{l}\text { M9C } \\
1 \mathrm{~B} 8\end{array}$ & $\begin{array}{l}\text { Traditional Shopping } \\
\text { Center }\end{array}$ \\
\hline Vince Camuto & USA & Toronto Eaton Centre & Toronto & $\begin{array}{l}220 \text { Yonge St, } \\
\text { Toronto, ON }\end{array}$ & ON & $\begin{array}{l}\text { M5B } \\
2 \mathrm{H} 1\end{array}$ & Major Downtown Mall \\
\hline Vince Camuto & USA & Toronto Premium Outlet & Toronto & $\begin{array}{l}13850 \text { Steeles } \\
\text { Avenue W, } \\
\text { Halton Hills, } \\
\text { ON }\end{array}$ & ON & L7G 0J1 & Outlet Mall \\
\hline Vince Camuto & USA & Vaughan Mills & Toronto & $\begin{array}{l}1 \text { Bass Pro } \\
\text { Mills Dr, } \\
\text { Concord, ON }\end{array}$ & ON & $\begin{array}{l}\text { L4K } \\
5 W 4\end{array}$ & Outlet Mall \\
\hline Vince Camuto & USA & Yorkdale Shopping Centre & Toronto & $\begin{array}{l}3401 \text { Dufferin } \\
\text { Street Unit } \\
217 \text {, Toronto, } \\
\text { ON }\end{array}$ & ON & $\begin{array}{l}\text { M6A } \\
2 \mathrm{~T} 9\end{array}$ & $\begin{array}{l}\text { Traditional Shopping } \\
\text { Center }\end{array}$ \\
\hline
\end{tabular}


Table A2: Raw variable list.

\begin{tabular}{|c|c|c|}
\hline Name & Type & Description \\
\hline Key & V_String & Census Tract ID \\
\hline Name & V_String & Census Tract Name \\
\hline TotPop & Double & Total Population \\
\hline TotPop_15 & Double & Total Population 15 Years Or Over \\
\hline Edu_HHPop25P & Double & Population 15 Years or Over by Educational Attainment, 2016 \\
\hline Edu_None & Double & No certificate, diploma or degree, 2016 \\
\hline Edu_HighSc & Double & High school certificate or equivalent, 2016 \\
\hline Edu_Trades & Double & Apprenticeship or trades certificate or diploma, 2016 \\
\hline Edu_College & Double & College, CEGEP or other non-university certificate or diploma, 2016 \\
\hline Edu_BelowBach & Double & University certificate or diploma below bachelor, 2016 \\
\hline Edu_UniBach & Double & University degree, 2016 \\
\hline Edu_AbvBach & Double & Above Bachelor's, 2016 \\
\hline Edu_Bach & Double & Bachelor's degree, 2016 \\
\hline Inc_TotHH & Double & Total Households \\
\hline Inc_Aggr & Double & Aggregate household income \\
\hline Inc_Low & Double & Income Low $(<\$ 40,000)$ \\
\hline Inc_LowMid & Double & Income Low-Middle $(\$ 40,000-\$ 60,000)$ \\
\hline Inc_Middle & Double & Income Middle $(\$ 60,000-\$ 90,000)$ \\
\hline Inc_UpperMid & Double & Income Upper-Middle $(\$ 90,000$ - $\$ 125,000)$ \\
\hline Inc_HighL & Double & Income High-Low $(\$ 125,000-\$ 150,000)$ \\
\hline Inc_HighM & Double & Income High-Middle $(\$ 150,000$ - $\$ 175,000)$ \\
\hline Inc_HighH & Double & Income High-High $(\$ 175,000>)$ \\
\hline Inc_AvgHHInc & Double & Average Household Income (Current Year \$) \\
\hline Ind_HHPop15P & Double & Household Population 15 Years Or Over For Industry \\
\hline Ind_InLabF & Double & In The Labour Force \\
\hline Ind_NotAppl & Double & Industry - Not Applicable \\
\hline Ind_All & Double & All Industries \\
\hline Ind_Agri & Double & 11 Agriculture, Forestry, Fishing And Hunting \\
\hline Ind_Mine & Double & 21 Mining, Quarrying, And Oil And Gas Extraction \\
\hline Ind_Util & Double & 22 Utilities \\
\hline Ind_Cstr & Double & 23 Construction \\
\hline Ind_Manu & Double & 31-33 Manufacturing \\
\hline Ind_WholeSal & Double & 41 Wholesale Trade \\
\hline Ind_Retail & Double & 44-45 Retail Trade \\
\hline Ind_Tran & Double & 48-49 Transportation And Warehousing \\
\hline Ind_Info & Double & 51 Information And Cultural Industries \\
\hline Ind_FinA & Double & 52 Finance And Insurance \\
\hline Ind_RealEst & Double & 53 Real Estate And Rental And Leasing \\
\hline Ind_Prof & Double & 54 Professional, Scientific And Technical Services \\
\hline
\end{tabular}




\begin{tabular}{|c|c|c|}
\hline Name & Type & Description \\
\hline Ind_Mgmt & Double & 55 Management Of Companies And Enterprises \\
\hline Ind_Admin & Double & $\begin{array}{l}56 \text { Administrative And Support, Waste Management And Remediation } \\
\text { Services H }\end{array}$ \\
\hline Ind_Educ & Double & 61 Educational Services \\
\hline Ind_HLTH & Double & 62 Health Care And Social Assistance \\
\hline Ind_Arts & Double & 71 Arts, Entertainment And Recreation \\
\hline Ind_AccFood & Double & 72 Accommodation And Food Services \\
\hline Ind_Other & Double & 81 Other Services (Except Publuc Administration) \\
\hline Ind_Publ & Double & 91 Public Administration \\
\hline Home_TotPop15P & Double & Total Population 15 Years Or Over \\
\hline Home_Married & Double & Married Or Living With A Common-Law Partner \\
\hline Home_NotMarSDW & Double & Not Married And Not Living With A Common-Law Partner \\
\hline Home_Single & Double & Single (Never Legally Married) \\
\hline Occp_HHPop15P & Double & Household Population 15 Years Or Over For Occupation \\
\hline Occp_InLF & Double & In The Labour Force \\
\hline Occp_NotApp & Double & Occupation Not Applicable \\
\hline Occp_All & Double & All Occupations \\
\hline Occp_Mgmt & Double & Management \\
\hline Occp_FinBis & Double & Business Finance Administration \\
\hline Occp_Art & Double & Occupations In Art, Culture, Recreation, Sport \\
\hline Occp_Health & Double & Occupations In Health \\
\hline Occp_Sci & Double & Occupations In Sciences \\
\hline Occp_Priml & Double & Occupations Unique To Primary Industries \\
\hline Occp_Manu & Double & Occupations Unique To Manufacture And Utilities \\
\hline Occp_SaleServ & Double & Occupations In Sales And Service \\
\hline Occp_SocSci & Double & Occupations In Social Science, Education, Government, Religion \\
\hline Occp_Trades & Double & Occupations In Trades, Transport, Operators \\
\hline Pop_F_Tot & Double & Females \\
\hline Pop_F_1519 & Double & Females 15 To 19 \\
\hline Pop_F_2024 & Double & Females 20 To 24 \\
\hline Pop_F_2529 & Double & Females 25 To 29 \\
\hline Pop_F_3034 & Double & Females 30 To 34 \\
\hline Pop_F_3539 & Double & Females 35 To 39 \\
\hline Pop_F_4044 & Double & Females 40 To 44 \\
\hline Pop_F_4549 & Double & Females 45 To 49 \\
\hline Pop_F_5054 & Double & Females 50 To 54 \\
\hline Pop_F_5559 & Double & Females 55 To 59 \\
\hline Pop_F_6064 & Double & Females 60 To 64 \\
\hline Pop_F_6569 & Double & Females 65 To 69 \\
\hline Pop_F_7074 & Double & Females 70 To 74 \\
\hline Pop_F_7579 & Double & Females 75 To 79 \\
\hline
\end{tabular}




\begin{tabular}{|c|c|c|}
\hline Name & Type & Description \\
\hline Pop_F_8084 & Double & Females 80 To 84 \\
\hline Pop_F_85P & Double & Females 85 Or Older \\
\hline Pop_M_Tot & Double & Males \\
\hline Pop_M_1519 & Double & Males 15 To 19 \\
\hline Pop_M_2024 & Double & Males 20 To 24 \\
\hline Pop_M_2529 & Double & Males 25 To 29 \\
\hline Pop_M_3034 & Double & Males 30 To 34 \\
\hline Pop_M_3539 & Double & Males 35 To 39 \\
\hline Pop_M_4044 & Double & Males 40 To 44 \\
\hline Pop_M_4549 & Double & Males 45 To 49 \\
\hline Pop_M_5054 & Double & Males 50 To 54 \\
\hline Pop_M_5559 & Double & Males 55 To 59 \\
\hline Pop_M_6064 & Double & Males 60 To 64 \\
\hline Pop_M_6569 & Double & Males 65 To 69 \\
\hline Pop_M_7074 & Double & Males 70 To 74 \\
\hline Pop_M_7579 & Double & Males 75 To 79 \\
\hline Pop_M_8084 & Double & Males 80 To 84 \\
\hline Pop_M_85P & Double & Males 85 Or Older \\
\hline VisM_TotHHPop & Double & Household Population For Visible Minority \\
\hline VisM_Tot & Double & Visible Minority Total \\
\hline VisM_Chinese & Double & Visible Minority Chinese \\
\hline VisM_SAsia & Double & Visible Minority South Asian \\
\hline VisM_Black & Double & Visible Minority Black \\
\hline VisM_Filipino & Double & Visible Minority Filipino \\
\hline VisM_LatinAm & Double & Visible Minority Latin American \\
\hline VisM_SEAsia & Double & Visible Minority Southeast Asian \\
\hline VisM_Arab & Double & Visible Minority Arab \\
\hline VisM_WAsia & Double & Visible Minority West Asian \\
\hline VisM_Korean & Double & Visible Minority Korean \\
\hline VisM_Japanese & Double & Visible Minority Japanese \\
\hline VisM_Other & Double & Visible Minority All Other Visible Minorities \\
\hline VisM_Multi & Double & Visible Minority Multiple Visible Minorities \\
\hline VisM_Not & Double & Visible Minority Not A Visible Minority \\
\hline HS_Tot_HH & Double & Total Households \\
\hline HS_Tot_Dislnc & Double & Household Disposable Income \\
\hline HS_Tot_Disclnc & Double & Household Discretionary Income \\
\hline HS_TotExpend & Double & Total expenditure \\
\hline HS_TotConsumption & Double & Total current consumption \\
\hline HS_Shelter & Double & Shelter \\
\hline HS_Food & Double & Food \\
\hline
\end{tabular}




\begin{tabular}{|l|l|l|}
\hline Name & Type & Description \\
\hline HS_HHOper & Double & Household operation \\
\hline HS_HealthCare & Double & Health care \\
\hline HS_Trans & Double & Transportation \\
\hline HS_Rec & Double & Recreation \\
\hline HS_PersCare & Double & Personal care \\
\hline HS_Clothing & Double & Clothing \\
\hline HS_IncTax & Double & Income tax \\
\hline
\end{tabular}


Table A3: Relative variables equations.

\begin{tabular}{|c|c|c|}
\hline Raw Variable Name & Relative Variable Name & Expression \\
\hline Edu_AbvBach & Edu_AbvBach_R & $([$ Edu_AbvBach]/[EDU_HHPop25P] $) * 100$ \\
\hline Edu_Bach & Edu_Bach_R & $([$ Edu_Bach]/[EDU_HHPop25P])*100 \\
\hline Edu_BelowBach & Edu_BelowBach_R & $([$ Edu_BelowBach]/[EDU_HHPop25P])*100 \\
\hline Edu_College & Edu_College_R & $([$ Edu_College]/[EDU_HHPop25P] $) * 100$ \\
\hline Edu_HighSc & Edu_HighSc_R & $([$ Edu_HighSc]/[EDU_HHPop25P] $) * 100$ \\
\hline Edu_None & Edu_None_R & $([$ Edu_None]/[EDU_HHPop25P])*100 \\
\hline Edu_Trades & Edu_Trades_R & $([$ Edu_Trades]/[EDU_HHPop25P] $) * 100$ \\
\hline Edu_UniBach & Edu_UniBach_R & $([$ Edu_UniBach]/[EDU_HHPop25P])*100 \\
\hline HS_Clothing & HS_Clothing_R & $\left(\left[\mathrm{HS} \_C l o t h i n g\right] /\left[\mathrm{HS} \_T o t C o n s u m p t i o n\right]\right) * 100$ \\
\hline HS_Food & HS_Food_R & $\left(\left[\mathrm{HS} \_\right.\right.$Food] $/[$HS_TotConsumption] $) * 100$ \\
\hline HS_HHOper & HS_HHOper_R & $\left(\left[\mathrm{HS} \_H H O p e r\right] /\left[\mathrm{HS} \_T o t C o n s u m p t i o n\right]\right) * 100$ \\
\hline HS_HealthCare & HS_HealthCare_R & $\left(\left[\mathrm{HS} \_H e a l t h C a r e\right] /\left[\mathrm{HS} \_T o t C o n s u m p t i o n\right]\right) * 100$ \\
\hline HS_IncTax & HS_IncTax_R & $([\mathrm{HS}$ IncTax]/[HS_Tot_DisInc] $) * 100$ \\
\hline HS_PersCare & HS_PersCare_R & $([$ HS_PersCare]/[HS_TotConsumption] $) * 100$ \\
\hline HS_Rec & HS_Rec_R & $\left(\left[\mathrm{HS} \_\right.\right.$Rec] $\left.] /\left[\mathrm{HS} \_T o t C o n s u m p t i o n\right]\right) * 100$ \\
\hline HS_Shelter & HS_Shelter_R & $\left(\left[\mathrm{HS} \_S h e l t e r\right] /\left[\mathrm{HS} \_T o t C o n s u m p t i o n\right]\right) * 100$ \\
\hline HS_Trans & HS_Trans_R & $\left(\left[\mathrm{HS} \_\right.\right.$Trans] $/\left[\mathrm{HS} \_\right.$TotConsumption] $) * 100$ \\
\hline Home_Married & Home_Married_R & $([$ Home_Married]/[Home_TotPop15P])*100 \\
\hline Home_NotMar & Home_NotMar_R & $([$ Home_NotMarSDW]/[Home_TotPop15P] $) * 100$ \\
\hline Home_Single & Home_Single_R & $([$ Home_Single]/[Home_TotPop15P]) $* 100$ \\
\hline Inc_AvgHHInc & Inc_AvgHHInc & Inc_Aggr/Inc_TotHH \\
\hline Inc_HighL & Inc_HighL_R & $([$ Inc_HighL $] /[$ Inc_TotHH] $) * 100$ \\
\hline Inc_HighM & Inc_HighM_R & $([$ Inc_HighM] $] /[$ Inc_TotHH] $) * 100$ \\
\hline Inc_HighH & Inc_HighH_R & $([$ Inc_HighH $] /[$ Inc_TotHH] $] * 100$ \\
\hline Inc_Low & Inc_Low_R & $([$ Inc_Low $] /[$ Inc_TotHH] $) * 100$ \\
\hline Inc_LowMid & Inc_LowMid_R & $([$ Inc_LowMid] $] /[$ Inc_TotHH] $) * 100$ \\
\hline Inc_Middle & Inc_Middle_R & $([$ Inc_Middle]/[Inc_TotHH $]) * 100$ \\
\hline Inc_UpperMid & Inc_UpperMid_R & $([$ Inc_UpperMid] $] /[$ Inc_TotHH] $) * 100$ \\
\hline Ind_AccFood & Ind_AccFood_R & $([$ Ind_AccFood $] /[$ Ind_All] $] * 100$ \\
\hline Ind_Admin & Ind_Admin_R & $([$ Ind_Admin $] /[$ Ind_All $]) * 100$ \\
\hline Ind_Agri & Ind_Agri_R & $([$ Ind_Agri] $] /[$ Ind_All] $) * 100$ \\
\hline Ind_Arts & Ind_Arts_R & $([$ Ind_Arts] $/[$ Ind_All] $) * 100$ \\
\hline Ind_Cstr & Ind_Cstr_R & $([$ Ind_Cstr]/[Ind_All] $) * 100$ \\
\hline Ind_Educ & Ind_Educ_R & $([$ Ind_Educ] $] /[$ Ind_All] $] * 100$ \\
\hline Ind_FinA & Ind_FinA_R & $([$ Ind_FinA $] /[$ Ind_All] $]) * 100$ \\
\hline Ind_HLTH & Ind_HLTH_R & $([$ Ind_HLTH $] /[$ Ind_All $]) * 100$ \\
\hline Ind_Info & Ind_Info_R & $([$ Ind_Info] $] /[$ Ind_All] $]) * 100$ \\
\hline Ind_Manu & Ind_Manu_R & $([$ Ind_Manu $] /[$ Ind_All $]) * 100$ \\
\hline Ind_Mgmt & Ind_Mgmt_R & $([$ Ind_Mgmt $] /[$ Ind_All] $) * 100$ \\
\hline
\end{tabular}




\begin{tabular}{|c|c|c|}
\hline Raw Variable Name & Relative Variable Name & Expression \\
\hline Ind_Mine & Ind_Mine_R & $([$ Ind_Mine $] /[$ Ind_All] $]) * 100$ \\
\hline Ind_Other & Ind_Other_R & $([$ Ind_Other] $] /[$ Ind_All] $] * 100$ \\
\hline Ind_Prof & Ind_Prof_R & ([Ind_Prof]/[Ind_All] $) * 100$ \\
\hline Ind_Publ & Ind_Publ_R & $([$ Ind_Publ]/[Ind_All] $) * 100$ \\
\hline Ind_RealEst & Ind_RealEst_R & $([$ Ind_RealEst $] /[$ Ind_All $]) * 100$ \\
\hline Ind_Retail & Ind_Retail_R & $([$ Ind_Retail]/[Ind_All] $) * 100$ \\
\hline Ind_Tran & Ind_Tran_R & $([$ Ind_Tran] $] /[$ Ind_All $]) * 100$ \\
\hline Ind_Util & Ind_Util_R & $([$ Ind_Util] $] /[$ Ind_All] $]) * 100$ \\
\hline Ind_WholeSal & Ind_WholeSal_R & $([$ Ind_WholeSal] $] /[$ Ind_All] $]) * 100$ \\
\hline Occp_Art & Occp_Art_R & $([$ Occp_Art $] /[$ Occp_All] $) * 100$ \\
\hline Occp_FinBis & Occp_FinBis_R & $([$ Occp_FinBis]/[Occp_All] $) * 100$ \\
\hline Occp_Health & Occp_Health_R & $([$ Occp_Health]/[Occp_All] $) * 100$ \\
\hline Occp_Manu & Occp_Manu_R & $([$ Occp_Manu]/[Occp_All] $) * 100$ \\
\hline Occp_Mgmt & Occp_Mgmt_R & $([$ Occp_Mgmt $] /[$ Occp_All] $) * 100$ \\
\hline Occp_Priml & Occp_Priml_R & $\left([\right.$ Occp_Priml] $\left.] /\left[O c c p \_A l l\right]\right) * 100$ \\
\hline Occp_SaleServ & Occp_SaleServ_R & $([$ Occp_SaleServ]/[Occp_All] $) * 100$ \\
\hline Occp_Sci & Occp_Sci_R & $([$ Occp_Sci] $/[$ Occp_All] $) * 100$ \\
\hline Occp_SocSci & Occp_SocSci_R & $([$ Occp_SocSci]/[Occp_All] $) * 100$ \\
\hline Occp_Trades & Occp_Trades_R & $([$ Occp_Trades]/[Occp_All] $) * 100$ \\
\hline Pop_F_1519 & Pop_F_1519_R & $([$ Pop_F_1519]/[Pop_F_Tot $]) * 100$ \\
\hline Pop_F_2024 & Pop_F_2024_R & $([$ Pop_F_2024]/[Pop_F_Tot] $) * 100$ \\
\hline Pop_F_2529 & Pop_F_2529_R & $([$ Pop_F_2529]/[Pop_F_Tot] $) * 100$ \\
\hline Pop_F_3034 & Pop_F_3034_R & $([$ Pop_F_3034]/[Pop_F_Tot] $) * 100$ \\
\hline Pop_F_3539 & Pop_F_3539_R & $([$ Pop_F_3539]/[Pop_F_Tot] $) * 100$ \\
\hline Pop_F_4044 & Pop_F_4044_R & $([$ Pop_F_4044]/[Pop_F_Tot] $) * 100$ \\
\hline Pop_F_4549 & Pop_F_4549_R & $([$ Pop_F_4549]/[Pop_F_Tot] $) * 100$ \\
\hline Pop_F_5054 & Pop_F_5054_R & $([$ Pop_F_5054]/[Pop_F_Tot] $) * 100$ \\
\hline Pop_F_5559 & Pop_F_5559_R & $([$ Pop_F_5559]/[Pop_F_Tot] $) * 100$ \\
\hline Pop_F_6064 & Pop_F_6064_R & $([$ Pop_F_6064]/[Pop_F_Tot] $) * 100$ \\
\hline Pop_F_6569 & Pop_F_6569_R & $([$ Pop_F_6569]/[Pop_F_Tot] $) * 100$ \\
\hline Pop_F_7074 & Pop_F_7074_R & $([$ Pop_F_7074] $/[$ Pop_F_Tot $]) * 100$ \\
\hline Pop_F_7579 & Pop_F_7579_R & $([$ Pop_F_7579]/[Pop_F_Tot $]) * 100$ \\
\hline Pop_F_8084 & Pop_F_8084_R & $([$ Pop_F_8084]/[Pop_F_Tot $]) * 100$ \\
\hline Pop_F_85P & Pop_F_85P_R & $([$ Pop_F_85P]/[Pop_F_Tot $]) * 100$ \\
\hline Pop_M_1519 & Pop_M_1519_R & $([$ Pop_M_1519]/[Pop_M_Tot $]) * 100$ \\
\hline Pop_M_2024 & Pop_M_2024_R & $([$ Pop_M_2024]/[Pop_M_Tot $]) * 100$ \\
\hline Pop_M_2529 & Pop_M_2529_R & $([$ Pop_M_2529]/[Pop_M_Tot $]) * 100$ \\
\hline Pop_M_3034 & Pop_M_3034_R & $([$ Pop_M_3034]/[Pop_M_Tot $]) * 100$ \\
\hline Pop_M_3539 & Pop_M_3539_R & $([$ Pop_M_3539]/[Pop_M_Tot $]) * 100$ \\
\hline Pop_M_4044 & Pop_M_4044_R & $([$ Pop_M_4044]/[Pop_M_Tot $]) * 100$ \\
\hline
\end{tabular}




\begin{tabular}{|c|c|c|}
\hline Raw Variable Name & Relative Variable Name & Expression \\
\hline Pop_M_4549 & Pop_M_4549_R & $([$ Pop_M_4549]/[Pop_M_Tot] $) * 100$ \\
\hline Pop_M_5054 & Pop_M_5054_R & $([$ Pop_M_5054]/[Pop_M_Tot] $) * 100$ \\
\hline Pop_M_5559 & Pop_M_5559_R & $([$ Pop_M_5559]/[Pop_M_Tot] $) * 100$ \\
\hline Pop_M_6064 & Pop_M_6064_R & $([$ Pop_M_6064]/[Pop_M_Tot] $) * 100$ \\
\hline Pop_M_6569 & Pop_M_6569_R & $([$ Pop_M_6569]/[Pop_M_Tot $]) * 100$ \\
\hline Pop_M_7074 & Pop_M_7074_R & $([$ Pop_M_7074]/[Pop_M_Tot] $) * 100$ \\
\hline Pop_M_7579 & Pop_M_7579_R & $([$ Pop_M_7579]/[Pop_M_Tot] $) * 100$ \\
\hline Pop_M_8084 & Pop_M_8084_R & $([$ Pop_M_8084]/[Pop_M_Tot $]) * 100$ \\
\hline Pop_M_85P & Pop_M_85P_R & $([$ Pop_M_85P]/[Pop_M_Tot $]) * 100$ \\
\hline VisM_Arab & VisM_Arab_R & $([$ VisM_Arab]/[VisM_Tot] $) * 100$ \\
\hline VisM_Black & VisM_Black_R & $([$ VisM_Black]/[VisM_Tot] $) * 100$ \\
\hline dwwVisM_Chinese & VisM_Chinese_R & $([$ VisM_Chinese]/[VisM_Tot] $) * 100$ \\
\hline VisM_Filipino & VisM_Filipino_R & $([$ VisM_Filipino]/[VisM_Tot] $) * 100$ \\
\hline VisM_Japanese & VisM_Japanese_R & $([$ VisM_Japanese]/[VisM_Tot] $) * 100$ \\
\hline VisM_Korean & VisM_Korean_R & $([$ VisM_Korean]/[VisM_Tot] $) * 100$ \\
\hline VisM_LatinAm & VisM_LatinAm_R & $([$ VisM_LatinAm] $/[$ VisM_Tot] $) * 100$ \\
\hline VisM_Not & VisM_Not_R & $([$ VisM_Not]/[VisM_TotHHPop] $) * 100$ \\
\hline VisM_SAsia & VisM_SAsia_R & $([$ VisM_SAsia] $] /[$ VisM_Tot] $) * 100$ \\
\hline VisM_SEAsia & VisM_SEAsia_R & $([$ VisM_SEAsia]/[VisM_Tot] $) * 100$ \\
\hline VisM_WAsia & VisM_WAsia_R & $([$ VisM_WAsia]/[VisM_Tot] $) * 100$ \\
\hline
\end{tabular}


Table A4: Relative trade area data for female age variables.

\begin{tabular}{|c|c|c|c|c|c|c|c|c|c|c|c|c|c|c|c|c|c|c|}
\hline \multirow[t]{2}{*}{ Variable Description } & \multicolumn{2}{|c|}{$\begin{array}{c}\text { Chinook } \\
\text { Centre }\end{array}$} & \multicolumn{2}{|c|}{$\begin{array}{l}\text { Downtown } \\
\text { Vancouver }\end{array}$} & \multicolumn{2}{|c|}{$\begin{array}{l}\text { Rideau } \\
\text { Centre }\end{array}$} & \multicolumn{2}{|c|}{$\begin{array}{l}\text { Sherway } \\
\text { Gardens }\end{array}$} & \multicolumn{2}{|c|}{$\begin{array}{l}\text { Square } \\
\text { One }\end{array}$} & \multicolumn{2}{|c|}{$\begin{array}{l}\text { Toronto } \\
\text { Eaton } \\
\text { Centre }\end{array}$} & \multicolumn{2}{|c|}{$\begin{array}{l}\text { Toronto } \\
\text { Premium } \\
\text { Outlet }\end{array}$} & \multicolumn{2}{|c|}{$\begin{array}{l}\text { Yorkdale } \\
\text { Shopping } \\
\text { Centre }\end{array}$} & \multicolumn{2}{|c|}{ Yorkville } \\
\hline & $\begin{array}{c}15 \\
\min \end{array}$ & $\begin{array}{c}20 \\
\min \end{array}$ & $\begin{array}{l}15 \\
\min \end{array}$ & $\begin{array}{l}20 \\
\min \end{array}$ & $\begin{array}{l}15 \\
\min \end{array}$ & $\begin{array}{c}20 \\
\min \end{array}$ & $\begin{array}{c}15 \\
\min \end{array}$ & $\begin{array}{c}20 \\
\min \end{array}$ & $\begin{array}{c}15 \\
\min \end{array}$ & $\begin{array}{c}20 \\
\min \end{array}$ & $\begin{array}{c}15 \\
\min \end{array}$ & $\begin{array}{c}20 \\
\min \end{array}$ & $\begin{array}{c}15 \\
\min \end{array}$ & $\begin{array}{c}20 \\
\min \end{array}$ & $\begin{array}{c}15 \\
\min \end{array}$ & $\begin{array}{l}20 \\
\min \end{array}$ & $\begin{array}{c}15 \\
\min \end{array}$ & $\begin{array}{c}20 \\
\min \end{array}$ \\
\hline Females 15 To 19 & $5 \%$ & $5 \%$ & $4 \%$ & $4 \%$ & $5 \%$ & $5 \%$ & $5 \%$ & $5 \%$ & $6 \%$ & $6 \%$ & $4 \%$ & $5 \%$ & $7 \%$ & $6 \%$ & $5 \%$ & $5 \%$ & $4 \%$ & $5 \%$ \\
\hline Females 20 To 24 & $7 \%$ & $7 \%$ & $7 \%$ & $7 \%$ & $7 \%$ & $7 \%$ & $7 \%$ & $7 \%$ & $7 \%$ & $7 \%$ & $6 \%$ & $6 \%$ & $7 \%$ & $7 \%$ & $7 \%$ & $7 \%$ & $6 \%$ & $6 \%$ \\
\hline Females 25 To 29 & $9 \%$ & $8 \%$ & $9 \%$ & $9 \%$ & $9 \%$ & $8 \%$ & $9 \%$ & $8 \%$ & $7 \%$ & $7 \%$ & $9 \%$ & $8 \%$ & $7 \%$ & $7 \%$ & $9 \%$ & $8 \%$ & $9 \%$ & $8 \%$ \\
\hline Females 30 To 34 & $9 \%$ & $9 \%$ & $9 \%$ & $9 \%$ & $8 \%$ & $7 \%$ & $9 \%$ & $9 \%$ & $7 \%$ & $8 \%$ & $10 \%$ & $9 \%$ & $7 \%$ & $7 \%$ & $9 \%$ & $8 \%$ & $10 \%$ & $9 \%$ \\
\hline Females 35 To 39 & $8 \%$ & $8 \%$ & $8 \%$ & $7 \%$ & $7 \%$ & $7 \%$ & $8 \%$ & $8 \%$ & $7 \%$ & $8 \%$ & $9 \%$ & $8 \%$ & $7 \%$ & $7 \%$ & $8 \%$ & $8 \%$ & $8 \%$ & $8 \%$ \\
\hline Females 40 To 44 & $7 \%$ & $7 \%$ & $7 \%$ & $7 \%$ & $6 \%$ & $7 \%$ & $7 \%$ & $7 \%$ & $7 \%$ & $7 \%$ & $7 \%$ & $7 \%$ & $8 \%$ & $7 \%$ & $7 \%$ & $7 \%$ & $7 \%$ & $7 \%$ \\
\hline Females 45 To 49 & $7 \%$ & $7 \%$ & $7 \%$ & $7 \%$ & $6 \%$ & $7 \%$ & $7 \%$ & $7 \%$ & $7 \%$ & $7 \%$ & $7 \%$ & $7 \%$ & $8 \%$ & $7 \%$ & $7 \%$ & $7 \%$ & $7 \%$ & $7 \%$ \\
\hline Females 50 To 54 & $7 \%$ & $7 \%$ & $7 \%$ & $7 \%$ & $7 \%$ & $7 \%$ & $7 \%$ & $7 \%$ & $8 \%$ & $7 \%$ & $7 \%$ & $7 \%$ & $8 \%$ & $8 \%$ & $7 \%$ & $7 \%$ & $7 \%$ & $7 \%$ \\
\hline Females 55 To 59 & $7 \%$ & $7 \%$ & $7 \%$ & $7 \%$ & $7 \%$ & $7 \%$ & $7 \%$ & $7 \%$ & $7 \%$ & $7 \%$ & $6 \%$ & $7 \%$ & $7 \%$ & $7 \%$ & $6 \%$ & $7 \%$ & $6 \%$ & $7 \%$ \\
\hline Females 60 To 64 & $6 \%$ & $5 \%$ & $6 \%$ & $6 \%$ & $6 \%$ & $6 \%$ & $5 \%$ & $5 \%$ & $6 \%$ & $5 \%$ & $5 \%$ & $6 \%$ & $5 \%$ & $5 \%$ & $6 \%$ & $6 \%$ & $5 \%$ & $6 \%$ \\
\hline Females 65 To 69 & $4 \%$ & $4 \%$ & $5 \%$ & $5 \%$ & $5 \%$ & $5 \%$ & $5 \%$ & $5 \%$ & $5 \%$ & $5 \%$ & $5 \%$ & $5 \%$ & $4 \%$ & $5 \%$ & $5 \%$ & $5 \%$ & $5 \%$ & $5 \%$ \\
\hline Females 70 To 74 & $3 \%$ & $3 \%$ & $4 \%$ & $4 \%$ & $4 \%$ & $4 \%$ & $3 \%$ & $3 \%$ & $3 \%$ & $3 \%$ & $3 \%$ & $4 \%$ & $3 \%$ & $3 \%$ & $4 \%$ & $3 \%$ & $3 \%$ & $4 \%$ \\
\hline Females 75 To 79 & $2 \%$ & $2 \%$ & $3 \%$ & $3 \%$ & $3 \%$ & $3 \%$ & $3 \%$ & $3 \%$ & $3 \%$ & $3 \%$ & $3 \%$ & $3 \%$ & $2 \%$ & $2 \%$ & $3 \%$ & $3 \%$ & $3 \%$ & $3 \%$ \\
\hline Females 80 To 84 & $2 \%$ & $2 \%$ & $2 \%$ & $2 \%$ & $2 \%$ & $2 \%$ & $2 \%$ & $2 \%$ & $2 \%$ & $2 \%$ & $2 \%$ & $2 \%$ & $1 \%$ & $2 \%$ & $2 \%$ & $2 \%$ & $2 \%$ & $2 \%$ \\
\hline Females 85 Or Older & $2 \%$ & $2 \%$ & $3 \%$ & $3 \%$ & $3 \%$ & $3 \%$ & $3 \%$ & $3 \%$ & $2 \%$ & $2 \%$ & $3 \%$ & $3 \%$ & $2 \%$ & $2 \%$ & $3 \%$ & $3 \%$ & $3 \%$ & $3 \%$ \\
\hline
\end{tabular}


Table A5: Relative trade area data for male age variables.

\begin{tabular}{|c|c|c|c|c|c|c|c|c|c|c|c|c|c|c|c|c|c|c|}
\hline \multirow[t]{2}{*}{ Variable Description } & \multicolumn{2}{|c|}{$\begin{array}{l}\text { Chinook } \\
\text { Centre }\end{array}$} & \multicolumn{2}{|c|}{$\begin{array}{l}\text { Downtown } \\
\text { Vancouver }\end{array}$} & \multicolumn{2}{|c|}{$\begin{array}{l}\text { Rideau } \\
\text { Centre }\end{array}$} & \multicolumn{2}{|c|}{$\begin{array}{l}\text { Sherway } \\
\text { Gardens }\end{array}$} & \multicolumn{2}{|c|}{$\begin{array}{l}\text { Square } \\
\text { One }\end{array}$} & \multicolumn{2}{|c|}{$\begin{array}{c}\text { Toronto } \\
\text { Eaton } \\
\text { Centre }\end{array}$} & \multicolumn{2}{|c|}{$\begin{array}{c}\text { Toronto } \\
\text { Premium } \\
\text { Outlet }\end{array}$} & \multicolumn{2}{|c|}{$\begin{array}{c}\text { Yorkdale } \\
\text { Shopping } \\
\text { Centre }\end{array}$} & \multicolumn{2}{|c|}{ Yorkville } \\
\hline & $\begin{array}{c}15 \\
\min \\
\end{array}$ & $\begin{array}{c}20 \\
\min \\
\end{array}$ & $\begin{array}{c}15 \\
\min \\
\end{array}$ & $\begin{array}{c}20 \\
\min \\
\end{array}$ & $\begin{array}{c}15 \\
\min \\
\end{array}$ & $\begin{array}{c}20 \\
\min \\
\end{array}$ & $\begin{array}{c}15 \\
\min \\
\end{array}$ & $\begin{array}{c}20 \\
\min \\
\end{array}$ & $\begin{array}{c}15 \\
\min \\
\end{array}$ & $\begin{array}{c}20 \\
\min \\
\end{array}$ & $\begin{array}{c}15 \\
\min \\
\end{array}$ & $\begin{array}{c}20 \\
\min \\
\end{array}$ & $\begin{array}{c}15 \\
\min \\
\end{array}$ & $\begin{array}{c}20 \\
\min \end{array}$ & $\begin{array}{c}15 \\
\min \\
\end{array}$ & $\begin{array}{c}20 \\
\min \\
\end{array}$ & $\begin{array}{c}15 \\
\min \\
\end{array}$ & $\begin{array}{c}20 \\
\min \end{array}$ \\
\hline Males 15 To 19 & $5 \%$ & $5 \%$ & $5 \%$ & $5 \%$ & $5 \%$ & $6 \%$ & $5 \%$ & $6 \%$ & $7 \%$ & $6 \%$ & $5 \%$ & $5 \%$ & $7 \%$ & $7 \%$ & $5 \%$ & $6 \%$ & $5 \%$ & $5 \%$ \\
\hline Males 20 To 24 & $7 \%$ & $7 \%$ & $8 \%$ & $8 \%$ & $8 \%$ & $8 \%$ & $7 \%$ & $7 \%$ & $8 \%$ & $7 \%$ & $7 \%$ & $7 \%$ & $8 \%$ & $8 \%$ & $7 \%$ & $7 \%$ & $7 \%$ & $7 \%$ \\
\hline Males 25 To 29 & $9 \%$ & $8 \%$ & $9 \%$ & $9 \%$ & $9 \%$ & $8 \%$ & $9 \%$ & $8 \%$ & $8 \%$ & $8 \%$ & $9 \%$ & $9 \%$ & $7 \%$ & $7 \%$ & $9 \%$ & $8 \%$ & $9 \%$ & $9 \%$ \\
\hline Males 30 To 34 & $10 \%$ & $9 \%$ & $9 \%$ & $9 \%$ & $8 \%$ & $8 \%$ & $9 \%$ & $8 \%$ & $7 \%$ & $7 \%$ & $10 \%$ & $9 \%$ & $7 \%$ & $7 \%$ & $9 \%$ & $8 \%$ & $10 \%$ & $9 \%$ \\
\hline Males 35 To 39 & $8 \%$ & $8 \%$ & $8 \%$ & $8 \%$ & $7 \%$ & $7 \%$ & $8 \%$ & $8 \%$ & $6 \%$ & $7 \%$ & $9 \%$ & $8 \%$ & $7 \%$ & $7 \%$ & $8 \%$ & $7 \%$ & $8 \%$ & $8 \%$ \\
\hline Males 40 To 44 & $7 \%$ & $7 \%$ & $7 \%$ & $7 \%$ & $6 \%$ & $7 \%$ & $7 \%$ & $7 \%$ & $7 \%$ & $7 \%$ & $8 \%$ & $7 \%$ & $7 \%$ & $7 \%$ & $7 \%$ & $7 \%$ & $7 \%$ & $7 \%$ \\
\hline Males 45 To 49 & $7 \%$ & $7 \%$ & $7 \%$ & $7 \%$ & $6 \%$ & $7 \%$ & $7 \%$ & $7 \%$ & $7 \%$ & $7 \%$ & $7 \%$ & $7 \%$ & $7 \%$ & $7 \%$ & $7 \%$ & $7 \%$ & $7 \%$ & $7 \%$ \\
\hline Males 50 To 54 & $7 \%$ & $7 \%$ & $7 \%$ & $7 \%$ & $7 \%$ & $8 \%$ & $7 \%$ & $8 \%$ & $8 \%$ & $8 \%$ & $7 \%$ & $7 \%$ & $8 \%$ & $8 \%$ & $7 \%$ & $8 \%$ & $7 \%$ & $7 \%$ \\
\hline Males 55 To 59 & $7 \%$ & $7 \%$ & $7 \%$ & $7 \%$ & $7 \%$ & $7 \%$ & $7 \%$ & $7 \%$ & $7 \%$ & $7 \%$ & $7 \%$ & $7 \%$ & $7 \%$ & $7 \%$ & $7 \%$ & $7 \%$ & $7 \%$ & $7 \%$ \\
\hline Males 60 To 64 & $6 \%$ & $6 \%$ & $6 \%$ & $6 \%$ & $6 \%$ & $6 \%$ & $5 \%$ & $5 \%$ & $6 \%$ & $5 \%$ & $5 \%$ & $5 \%$ & $5 \%$ & $5 \%$ & $5 \%$ & $6 \%$ & $5 \%$ & $6 \%$ \\
\hline Males 65 To 69 & $4 \%$ & $4 \%$ & $5 \%$ & $5 \%$ & $5 \%$ & $5 \%$ & $4 \%$ & $4 \%$ & $5 \%$ & $4 \%$ & $4 \%$ & $5 \%$ & $4 \%$ & $4 \%$ & $5 \%$ & $5 \%$ & $4 \%$ & $5 \%$ \\
\hline Males 70 To 74 & $3 \%$ & $2 \%$ & $3 \%$ & $3 \%$ & $4 \%$ & $3 \%$ & $3 \%$ & $3 \%$ & $3 \%$ & $3 \%$ & $3 \%$ & $3 \%$ & $3 \%$ & $3 \%$ & $3 \%$ & $3 \%$ & $3 \%$ & $3 \%$ \\
\hline Males 75 To 79 & $2 \%$ & $2 \%$ & $3 \%$ & $3 \%$ & $2 \%$ & $2 \%$ & $2 \%$ & $2 \%$ & $2 \%$ & $2 \%$ & $2 \%$ & $2 \%$ & $2 \%$ & $2 \%$ & $2 \%$ & $2 \%$ & $2 \%$ & $2 \%$ \\
\hline Males 80 To 84 & $1 \%$ & $1 \%$ & $2 \%$ & $2 \%$ & $2 \%$ & $2 \%$ & $2 \%$ & $2 \%$ & $2 \%$ & $2 \%$ & $2 \%$ & $2 \%$ & $1 \%$ & $1 \%$ & $2 \%$ & $2 \%$ & $2 \%$ & $2 \%$ \\
\hline Males 85 Or Older & $1 \%$ & $1 \%$ & $2 \%$ & $2 \%$ & $2 \%$ & $1 \%$ & $2 \%$ & $2 \%$ & $1 \%$ & $1 \%$ & $2 \%$ & $2 \%$ & $1 \%$ & $1 \%$ & $2 \%$ & $2 \%$ & $2 \%$ & $2 \%$ \\
\hline
\end{tabular}


Table A6: Relative trade area data for marital values.

\begin{tabular}{|c|c|c|c|c|c|c|c|c|c|c|c|c|c|c|c|c|c|c|}
\hline \multirow[b]{2}{*}{$\begin{array}{c}\text { Variable } \\
\text { Description }\end{array}$} & \multicolumn{2}{|c|}{$\begin{array}{l}\text { Chinook } \\
\text { Centre }\end{array}$} & \multicolumn{2}{|c|}{$\begin{array}{l}\text { Downtown } \\
\text { Vancouver }\end{array}$} & \multicolumn{2}{|c|}{$\begin{array}{l}\text { Rideau } \\
\text { Centre }\end{array}$} & \multicolumn{2}{|c|}{$\begin{array}{l}\text { Sherway } \\
\text { Gardens }\end{array}$} & \multicolumn{2}{|c|}{$\begin{array}{l}\text { Square } \\
\text { One }\end{array}$} & \multicolumn{2}{|c|}{$\begin{array}{c}\text { Toronto Eaton } \\
\text { Centre }\end{array}$} & \multicolumn{2}{|c|}{$\begin{array}{c}\text { Toronto } \\
\text { Premium } \\
\text { Outlet }\end{array}$} & \multicolumn{2}{|c|}{$\begin{array}{c}\text { Yorkdale } \\
\text { Shopping } \\
\text { Centre }\end{array}$} & \multicolumn{2}{|c|}{ Yorkville } \\
\hline & $\begin{array}{c}15 \\
\min \\
\end{array}$ & $\begin{array}{c}20 \\
\min \end{array}$ & $\begin{array}{r}15 \\
\min \\
\end{array}$ & $\begin{array}{c}20 \\
\min \\
\end{array}$ & $\begin{array}{c}15 \\
\min \\
\end{array}$ & $\begin{array}{c}20 \\
\min \\
\end{array}$ & $\begin{array}{c}15 \\
\min \\
\end{array}$ & $\begin{array}{c}20 \\
\min \\
\end{array}$ & $\begin{array}{c}15 \\
\min \end{array}$ & $\begin{array}{c}20 \\
\min \end{array}$ & $\begin{array}{c}15 \\
\min \end{array}$ & $\begin{array}{c}20 \\
\min \end{array}$ & $\begin{array}{c}15 \\
\min \end{array}$ & $\begin{array}{c}20 \\
\min \end{array}$ & $\begin{array}{c}15 \\
\min \end{array}$ & $\begin{array}{l}20 \\
\min \end{array}$ & $\begin{array}{c}15 \\
\min \end{array}$ & $\begin{array}{c}20 \\
\min \end{array}$ \\
\hline $\begin{array}{l}\text { Married Or } \\
\text { Living With A } \\
\text { Common-Law } \\
\text { Partner }\end{array}$ & $54 \%$ & $57 \%$ & $51 \%$ & $52 \%$ & $50 \%$ & $54 \%$ & $50 \%$ & $52 \%$ & $57 \%$ & $55 \%$ & $49 \%$ & $50 \%$ & $60 \%$ & $58 \%$ & $51 \%$ & $53 \%$ & $49 \%$ & $50 \%$ \\
\hline $\begin{array}{l}\text { Not Married Or } \\
\text { Living With A } \\
\text { Common-Law } \\
\text { Partner }\end{array}$ & $15 \%$ & $14 \%$ & $14 \%$ & $14 \%$ & $16 \%$ & $15 \%$ & $15 \%$ & $15 \%$ & $14 \%$ & $14 \%$ & $16 \%$ & $16 \%$ & $11 \%$ & $13 \%$ & $16 \%$ & $15 \%$ & $16 \%$ & $16 \%$ \\
\hline $\begin{array}{l}\text { Single (Never } \\
\text { Legally Married) }\end{array}$ & $31 \%$ & $29 \%$ & $35 \%$ & $34 \%$ & $33 \%$ & $32 \%$ & $35 \%$ & $33 \%$ & $30 \%$ & $31 \%$ & $35 \%$ & $33 \%$ & $29 \%$ & $29 \%$ & $34 \%$ & $32 \%$ & $35 \%$ & $33 \%$ \\
\hline
\end{tabular}


Table A7: Relative trade area data for education variables.

\begin{tabular}{|c|c|c|c|c|c|c|c|c|c|c|c|c|c|c|c|c|c|c|}
\hline \multirow[t]{2}{*}{ Variable Description } & \multicolumn{2}{|c|}{$\begin{array}{l}\text { Chinook } \\
\text { Centre }\end{array}$} & \multicolumn{2}{|c|}{$\begin{array}{l}\text { Downtown } \\
\text { Vancouver }\end{array}$} & \multicolumn{2}{|c|}{$\begin{array}{l}\text { Rideau } \\
\text { Centre }\end{array}$} & \multicolumn{2}{|c|}{$\begin{array}{l}\text { Sherway } \\
\text { Gardens }\end{array}$} & \multicolumn{2}{|c|}{ Square One } & \multicolumn{2}{|c|}{$\begin{array}{l}\text { Toronto } \\
\text { Eaton } \\
\text { Centre }\end{array}$} & \multicolumn{2}{|c|}{$\begin{array}{c}\text { Toronto } \\
\text { Premium } \\
\text { Outlet }\end{array}$} & \multicolumn{2}{|c|}{$\begin{array}{c}\text { Yorkdale } \\
\text { Shopping } \\
\text { Centre }\end{array}$} & \multicolumn{2}{|c|}{ Yorkville } \\
\hline & $\begin{array}{l}15 \\
\min \end{array}$ & $\begin{array}{l}20 \\
\min \end{array}$ & $\begin{array}{l}15 \\
\min \end{array}$ & $\begin{array}{l}20 \\
\min \end{array}$ & $\begin{array}{l}15 \\
\min \end{array}$ & $\begin{array}{l}20 \\
\min \end{array}$ & $\begin{array}{l}15 \\
\min \end{array}$ & $\begin{array}{l}20 \\
\min \end{array}$ & $\begin{array}{l}15 \\
\min \end{array}$ & $\begin{array}{l}20 \\
\min \end{array}$ & $\begin{array}{l}15 \\
\min \end{array}$ & $\begin{array}{l}20 \\
\min \end{array}$ & $\begin{array}{l}15 \\
\min \end{array}$ & $\begin{array}{l}20 \\
\min \end{array}$ & $\begin{array}{l}15 \\
\min \end{array}$ & $\begin{array}{l}20 \\
\min \end{array}$ & $\begin{array}{l}15 \\
\min \end{array}$ & $\begin{array}{l}20 \\
\min \end{array}$ \\
\hline $\begin{array}{l}\text { No certificate, } \\
\text { diploma or degree }\end{array}$ & $15 \%$ & $15 \%$ & $13 \%$ & $13 \%$ & $13 \%$ & $12 \%$ & $18 \%$ & $18 \%$ & $17 \%$ & $19 \%$ & $16 \%$ & $17 \%$ & $15 \%$ & $17 \%$ & $18 \%$ & $18 \%$ & $16 \%$ & $18 \%$ \\
\hline $\begin{array}{l}\text { High school } \\
\text { certificate or } \\
\text { equivalent }\end{array}$ & $24 \%$ & $24 \%$ & $22 \%$ & $23 \%$ & $20 \%$ & $20 \%$ & $23 \%$ & $23 \%$ & $25 \%$ & $25 \%$ & $20 \%$ & $22 \%$ & $25 \%$ & $26 \%$ & $22 \%$ & $23 \%$ & $20 \%$ & $22 \%$ \\
\hline $\begin{array}{l}\text { Apprenticeship or } \\
\text { trades certificate or } \\
\text { diploma }\end{array}$ & $8 \%$ & $8 \%$ & $6 \%$ & $6 \%$ & $6 \%$ & $6 \%$ & $5 \%$ & $5 \%$ & $6 \%$ & $6 \%$ & $4 \%$ & $5 \%$ & $6 \%$ & $6 \%$ & $5 \%$ & $5 \%$ & $4 \%$ & $5 \%$ \\
\hline $\begin{array}{l}\text { College, CEGEP or } \\
\text { other non-university } \\
\text { certificate or diploma }\end{array}$ & $16 \%$ & $16 \%$ & $14 \%$ & $14 \%$ & $16 \%$ & $16 \%$ & $14 \%$ & $14 \%$ & $16 \%$ & $16 \%$ & $13 \%$ & $14 \%$ & $17 \%$ & $17 \%$ & $13 \%$ & $14 \%$ & $13 \%$ & $14 \%$ \\
\hline $\begin{array}{l}\text { University certificate } \\
\text { or diploma below } \\
\text { bachelor }\end{array}$ & $5 \%$ & $6 \%$ & $7 \%$ & $7 \%$ & $4 \%$ & $4 \%$ & $5 \%$ & $5 \%$ & $6 \%$ & $6 \%$ & $5 \%$ & $5 \%$ & $6 \%$ & $6 \%$ & $5 \%$ & $5 \%$ & $5 \%$ & $5 \%$ \\
\hline University degree & $31 \%$ & $31 \%$ & $39 \%$ & $38 \%$ & $41 \%$ & $41 \%$ & $34 \%$ & $35 \%$ & $30 \%$ & $29 \%$ & $41 \%$ & $37 \%$ & $31 \%$ & $29 \%$ & $37 \%$ & $35 \%$ & $41 \%$ & $37 \%$ \\
\hline Bachelor's degree & $22 \%$ & $21 \%$ & $25 \%$ & $24 \%$ & $23 \%$ & $24 \%$ & $21 \%$ & $21 \%$ & $19 \%$ & $18 \%$ & $25 \%$ & $22 \%$ & $19 \%$ & $18 \%$ & $23 \%$ & $21 \%$ & $24 \%$ & $22 \%$ \\
\hline Above Bachelor's & $10 \%$ & $10 \%$ & $14 \%$ & $14 \%$ & $17 \%$ & $17 \%$ & $13 \%$ & $14 \%$ & $12 \%$ & $11 \%$ & $16 \%$ & $15 \%$ & $12 \%$ & $11 \%$ & $15 \%$ & $13 \%$ & $16 \%$ & $14 \%$ \\
\hline
\end{tabular}


Table A8: Relative trade area data for income variables.

\begin{tabular}{|c|c|c|c|c|c|c|c|c|c|c|c|c|c|c|c|c|c|c|}
\hline \multirow[b]{2}{*}{$\begin{array}{c}\text { Variable } \\
\text { Description }\end{array}$} & \multicolumn{2}{|c|}{$\begin{array}{l}\text { Chinook } \\
\text { Centre }\end{array}$} & \multicolumn{2}{|c|}{$\begin{array}{l}\text { Downtown } \\
\text { Vancouver }\end{array}$} & \multicolumn{2}{|c|}{$\begin{array}{l}\text { Rideau } \\
\text { Centre }\end{array}$} & \multicolumn{2}{|c|}{$\begin{array}{l}\text { Sherway } \\
\text { Gardens }\end{array}$} & \multicolumn{2}{|c|}{$\begin{array}{l}\text { Square } \\
\text { One }\end{array}$} & \multicolumn{2}{|c|}{$\begin{array}{l}\text { Toronto } \\
\text { Eaton } \\
\text { Centre }\end{array}$} & \multicolumn{2}{|c|}{$\begin{array}{l}\text { Toronto } \\
\text { Premium } \\
\text { Outlet }\end{array}$} & \multicolumn{2}{|c|}{$\begin{array}{l}\text { Yorkdale } \\
\text { Shopping } \\
\text { Centre }\end{array}$} & \multicolumn{2}{|c|}{ Yorkville } \\
\hline & $\begin{array}{c}15 \\
\min \end{array}$ & $\begin{array}{c}20 \\
\min \end{array}$ & $\begin{array}{c}15 \\
\min \end{array}$ & $\begin{array}{l}20 \\
\min \end{array}$ & $\begin{array}{c}15 \\
\min \end{array}$ & $\begin{array}{c}20 \\
\min \end{array}$ & $\begin{array}{c}15 \\
\min \end{array}$ & $\begin{array}{c}20 \\
\min \end{array}$ & $\begin{array}{c}15 \\
\min \end{array}$ & $\begin{array}{c}20 \\
\min \end{array}$ & $\begin{array}{c}15 \\
\min \end{array}$ & $\begin{array}{c}20 \\
\min \end{array}$ & $\begin{array}{c}15 \\
\min \end{array}$ & $\begin{array}{c}20 \\
\min \end{array}$ & $\begin{array}{c}15 \\
\min \\
\end{array}$ & $\begin{array}{c}20 \\
\min \end{array}$ & $\begin{array}{c}15 \\
\min \\
\end{array}$ & $\begin{array}{c}20 \\
\min \end{array}$ \\
\hline $\begin{array}{l}\text { Income Low } \\
(<\$ 40,000)\end{array}$ & $26 \%$ & $22 \%$ & $32 \%$ & $31 \%$ & $24 \%$ & $21 \%$ & $32 \%$ & $30 \%$ & $24 \%$ & $26 \%$ & $34 \%$ & $33 \%$ & $17 \%$ & $21 \%$ & $33 \%$ & $31 \%$ & $34 \%$ & $33 \%$ \\
\hline $\begin{array}{l}\text { Income Low- } \\
\text { Middle } \\
(\$ 40,000- \\
\$ 60,000)\end{array}$ & $15 \%$ & $14 \%$ & $16 \%$ & $16 \%$ & $14 \%$ & $13 \%$ & $16 \%$ & $15 \%$ & $15 \%$ & $15 \%$ & $15 \%$ & $16 \%$ & $12 \%$ & $14 \%$ & $16 \%$ & $16 \%$ & $15 \%$ & $16 \%$ \\
\hline $\begin{array}{l}\text { Income } \\
\text { Middle } \\
(\$ 60,000- \\
\$ 90,000)\end{array}$ & $17 \%$ & $18 \%$ & $19 \%$ & $19 \%$ & $20 \%$ & $20 \%$ & $18 \%$ & $18 \%$ & $20 \%$ & $19 \%$ & $17 \%$ & $18 \%$ & $20 \%$ & $20 \%$ & $17 \%$ & $18 \%$ & $17 \%$ & $18 \%$ \\
\hline $\begin{array}{l}\text { Income } \\
\text { Upper-Middle } \\
(\$ 90,000- \\
\$ 125,000)\end{array}$ & $13 \%$ & $14 \%$ & $13 \%$ & $13 \%$ & $14 \%$ & $16 \%$ & $13 \%$ & $14 \%$ & $16 \%$ & $16 \%$ & $12 \%$ & $12 \%$ & $20 \%$ & $18 \%$ & $12 \%$ & $13 \%$ & $12 \%$ & $12 \%$ \\
\hline $\begin{array}{l}\text { Income High- } \\
\text { Low }(\$ 125,000 \\
-\$ 150,000)\end{array}$ & $14 \%$ & $16 \%$ & $13 \%$ & $13 \%$ & $17 \%$ & $18 \%$ & $13 \%$ & $13 \%$ & $17 \%$ & $16 \%$ & $11 \%$ & $12 \%$ & $21 \%$ & $19 \%$ & $12 \%$ & $13 \%$ & $11 \%$ & $12 \%$ \\
\hline $\begin{array}{l}\text { Income High- } \\
\text { Middle } \\
(\$ 150,000- \\
\$ 175,000)\end{array}$ & $9 \%$ & $10 \%$ & $7 \%$ & $7 \%$ & $10 \%$ & $11 \%$ & $7 \%$ & $8 \%$ & $9 \%$ & $9 \%$ & $6 \%$ & $6 \%$ & $12 \%$ & $10 \%$ & $7 \%$ & $7 \%$ & $6 \%$ & $7 \%$ \\
\hline $\begin{array}{l}\text { Income High- } \\
\text { High } \\
(\$ 175,000>)\end{array}$ & $14 \%$ & $14 \%$ & $8 \%$ & $8 \%$ & $9 \%$ & $10 \%$ & $8 \%$ & $9 \%$ & $9 \%$ & $8 \%$ & $10 \%$ & $9 \%$ & $9 \%$ & $9 \%$ & $9 \%$ & $9 \%$ & $10 \%$ & $9 \%$ \\
\hline
\end{tabular}


Table A9: Average household income values for all trade areas.

\begin{tabular}{|l|l|}
\hline & Average Household Income (Current Year $\$$ ) \\
\hline Chinook Centre $(15 \mathrm{~min})$ & $\$ 134,642$ \\
\hline Chinook Centre $(20 \mathrm{~min})$ & $\$ 138,002$ \\
\hline Downtown Vancouver $(15 \mathrm{~min})$ & $\$ 97,648$ \\
\hline Downtown Vancouver $(20 \mathrm{~min})$ & $\$ 96,444$ \\
\hline Rideau Centre $(15 \mathrm{~min})$ & $\$ 101,075$ \\
\hline Rideau Centre $(20 \mathrm{~min})$ & $\$ 107,561$ \\
\hline Sherway Gardens $(15 \mathrm{~min})$ & $\$ 99,426$ \\
\hline Sherway Gardens $(20 \mathrm{~min})$ & $\$ 109,248$ \\
\hline Square One $(15 \mathrm{~min})$ & $\$ 107,127$ \\
\hline Square One $(20 \mathrm{~min})$ & $\$ 104,622$ \\
\hline Toronto Eaton Centre $(15 \mathrm{~min})$ & $\$ 112,342$ \\
\hline Toronto Eaton Centre $(20 \mathrm{~min})$ & $\$ 105,190$ \\
\hline Toronto Premium Outlet $(15 \mathrm{~min})$ & $\$ 111,680$ \\
\hline Toronto Premium Outlet $(20 \mathrm{~min})$ & $\$ 109,682$ \\
\hline Yorkdale Shopping Centre $(15 \mathrm{~min})$ & $\$ 107,911$ \\
\hline Yorkdale Shopping Centre $(20 \mathrm{~min})$ & $\$ 104,516$ \\
\hline Yorkville (15 min) & $\$ 110,710$ \\
\hline Yorkville (20 min) & $\$ 104,784$ \\
\hline
\end{tabular}


Table A10: Relative trade area data for industry variables - part 1.

\begin{tabular}{|c|c|c|c|c|c|c|c|c|c|c|c|c|c|c|c|c|c|c|}
\hline \multirow[b]{2}{*}{ Variable Description } & \multicolumn{2}{|c|}{$\begin{array}{l}\text { Chinook } \\
\text { Centre }\end{array}$} & \multicolumn{2}{|c|}{$\begin{array}{l}\text { Downtown } \\
\text { Vancouver }\end{array}$} & \multicolumn{2}{|c|}{$\begin{array}{l}\text { Rideau } \\
\text { Centre }\end{array}$} & \multicolumn{2}{|c|}{$\begin{array}{l}\text { Sherway } \\
\text { Gardens }\end{array}$} & \multicolumn{2}{|c|}{$\begin{array}{l}\text { Square } \\
\text { One }\end{array}$} & \multicolumn{2}{|c|}{$\begin{array}{l}\text { Toronto } \\
\text { Eaton } \\
\text { Centre }\end{array}$} & \multicolumn{2}{|c|}{$\begin{array}{c}\text { Toronto } \\
\text { Premium } \\
\text { Outlet }\end{array}$} & \multicolumn{2}{|c|}{$\begin{array}{l}\text { Yorkdale } \\
\text { Shopping } \\
\text { Centre }\end{array}$} & \multicolumn{2}{|c|}{ Yorkville } \\
\hline & $\begin{array}{c}15 \\
\min \end{array}$ & $\begin{array}{c}20 \\
\min \end{array}$ & $\begin{array}{c}15 \\
\min \end{array}$ & $\begin{array}{c}20 \\
\min \end{array}$ & $\begin{array}{c}15 \\
\min \end{array}$ & $\begin{array}{c}20 \\
\min \end{array}$ & $\begin{array}{c}15 \\
\min \end{array}$ & $\begin{array}{c}20 \\
\min \end{array}$ & $\begin{array}{c}15 \\
\min \end{array}$ & $\begin{array}{c}20 \\
\min \end{array}$ & $\begin{array}{c}15 \\
\min \end{array}$ & $\begin{array}{l}20 \\
\min \end{array}$ & $\begin{array}{c}15 \\
\min \end{array}$ & $\begin{array}{c}20 \\
\min \end{array}$ & $\begin{array}{c}15 \\
\min \end{array}$ & $\begin{array}{l}20 \\
\min \end{array}$ & $\begin{array}{c}15 \\
\min \end{array}$ & $\begin{array}{c}20 \\
\min \end{array}$ \\
\hline $\begin{array}{l}\text { Accommodation And Food } \\
\text { Services }\end{array}$ & $6 \%$ & $6 \%$ & $9 \%$ & $9 \%$ & $7 \%$ & $6 \%$ & $7 \%$ & $6 \%$ & $6 \%$ & $6 \%$ & $7 \%$ & $7 \%$ & $5 \%$ & $5 \%$ & $6 \%$ & $6 \%$ & $7 \%$ & $7 \%$ \\
\hline $\begin{array}{l}\text { Administrative And Support, } \\
\text { Waste Management And } \\
\text { Remediation Services H }\end{array}$ & $4 \%$ & $4 \%$ & $5 \%$ & $5 \%$ & $4 \%$ & $4 \%$ & $5 \%$ & $5 \%$ & $5 \%$ & $5 \%$ & $5 \%$ & $5 \%$ & $5 \%$ & $5 \%$ & $5 \%$ & $5 \%$ & $5 \%$ & $5 \%$ \\
\hline $\begin{array}{l}\text { Agriculture, Forestry, Fishing } \\
\text { And Hunting }\end{array}$ & $1 \%$ & $1 \%$ & $0 \%$ & $0 \%$ & $0 \%$ & $0 \%$ & $0 \%$ & $0 \%$ & $0 \%$ & $0 \%$ & $0 \%$ & $0 \%$ & $0 \%$ & $0 \%$ & $0 \%$ & $0 \%$ & $0 \%$ & $0 \%$ \\
\hline $\begin{array}{l}\text { Arts, Entertainment And } \\
\text { Recreation }\end{array}$ & $3 \%$ & $2 \%$ & $3 \%$ & $3 \%$ & $2 \%$ & $2 \%$ & $2 \%$ & $2 \%$ & $2 \%$ & $2 \%$ & $3 \%$ & $2 \%$ & $1 \%$ & $2 \%$ & $2 \%$ & $2 \%$ & $3 \%$ & $2 \%$ \\
\hline Construction & $9 \%$ & $9 \%$ & $5 \%$ & $5 \%$ & $4 \%$ & $4 \%$ & $5 \%$ & $5 \%$ & $5 \%$ & $6 \%$ & $4 \%$ & $5 \%$ & $5 \%$ & $5 \%$ & $5 \%$ & $5 \%$ & $4 \%$ & $5 \%$ \\
\hline Educational Services & $7 \%$ & $7 \%$ & $9 \%$ & $8 \%$ & $8 \%$ & $8 \%$ & $7 \%$ & $7 \%$ & $6 \%$ & $6 \%$ & $8 \%$ & $8 \%$ & $6 \%$ & $6 \%$ & $8 \%$ & $7 \%$ & $8 \%$ & $8 \%$ \\
\hline Finance And Insurance & $4 \%$ & $4 \%$ & $5 \%$ & $5 \%$ & $3 \%$ & $3 \%$ & $7 \%$ & $8 \%$ & $7 \%$ & $7 \%$ & $9 \%$ & $8 \%$ & $7 \%$ & $7 \%$ & $8 \%$ & $8 \%$ & $9 \%$ & $8 \%$ \\
\hline $\begin{array}{l}\text { Health Care And Social } \\
\text { Assistance }\end{array}$ & $9 \%$ & $9 \%$ & $11 \%$ & $11 \%$ & $11 \%$ & $11 \%$ & $9 \%$ & $9 \%$ & $8 \%$ & $8 \%$ & $10 \%$ & $10 \%$ & $8 \%$ & $8 \%$ & $10 \%$ & $9 \%$ & $10 \%$ & $10 \%$ \\
\hline $\begin{array}{l}\text { Information And Cultural } \\
\text { Industries }\end{array}$ & $2 \%$ & $2 \%$ & $5 \%$ & $5 \%$ & $3 \%$ & $3 \%$ & $4 \%$ & $4 \%$ & $3 \%$ & $3 \%$ & $5 \%$ & $5 \%$ & $3 \%$ & $3 \%$ & $4 \%$ & $4 \%$ & $5 \%$ & $5 \%$ \\
\hline Manufacturing & $5 \%$ & $6 \%$ & $5 \%$ & $6 \%$ & $3 \%$ & $3 \%$ & $9 \%$ & $9 \%$ & $11 \%$ & $11 \%$ & $6 \%$ & $7 \%$ & $12 \%$ & $12 \%$ & $8 \%$ & $9 \%$ & $6 \%$ & $7 \%$ \\
\hline $\begin{array}{l}\text { Management Of Companies } \\
\text { And Enterprises }\end{array}$ & $0 \%$ & $0 \%$ & $0 \%$ & $0 \%$ & $0 \%$ & $0 \%$ & $0 \%$ & $0 \%$ & $0 \%$ & $0 \%$ & $0 \%$ & $0 \%$ & $0 \%$ & $0 \%$ & $0 \%$ & $0 \%$ & $0 \%$ & $0 \%$ \\
\hline
\end{tabular}


Table A11: Relative trade area data for industry variables - part 2.

\begin{tabular}{|c|c|c|c|c|c|c|c|c|c|c|c|c|c|c|c|c|c|c|}
\hline \multirow[b]{2}{*}{$\begin{array}{c}\text { Variable } \\
\text { Description }\end{array}$} & \multicolumn{2}{|c|}{$\begin{array}{l}\text { Chinook } \\
\text { Centre }\end{array}$} & \multicolumn{2}{|c|}{$\begin{array}{l}\text { Downtown } \\
\text { Vancouver }\end{array}$} & \multicolumn{2}{|c|}{$\begin{array}{l}\text { Rideau } \\
\text { Centre }\end{array}$} & \multicolumn{2}{|c|}{$\begin{array}{l}\text { Sherway } \\
\text { Gardens }\end{array}$} & \multicolumn{2}{|c|}{$\begin{array}{l}\text { Square } \\
\text { One }\end{array}$} & \multicolumn{2}{|c|}{$\begin{array}{l}\text { Toronto } \\
\text { Eaton } \\
\text { Centre }\end{array}$} & \multicolumn{2}{|c|}{$\begin{array}{l}\text { Toronto } \\
\text { Premium } \\
\text { Outlet }\end{array}$} & \multicolumn{2}{|c|}{$\begin{array}{c}\text { Yorkdale } \\
\text { Shopping } \\
\text { Centre }\end{array}$} & \multicolumn{2}{|c|}{ Yorkville } \\
\hline & $\begin{array}{c}15 \\
\min \end{array}$ & $\begin{array}{c}20 \\
\min \end{array}$ & $\begin{array}{c}15 \\
\min \end{array}$ & $\begin{array}{c}20 \\
\min \end{array}$ & $\begin{array}{c}15 \\
\min \end{array}$ & $\begin{array}{c}20 \\
\min \end{array}$ & $\begin{array}{c}15 \\
\min \end{array}$ & $\begin{array}{c}20 \\
\min \end{array}$ & $\begin{array}{c}15 \\
\min \end{array}$ & $\begin{array}{c}20 \\
\min \end{array}$ & $\begin{array}{c}15 \\
\min \end{array}$ & $\begin{array}{c}20 \\
\min \end{array}$ & $\begin{array}{c}15 \\
\min \end{array}$ & $\begin{array}{c}20 \\
\min \end{array}$ & $\begin{array}{c}15 \\
\min \end{array}$ & $\begin{array}{c}20 \\
\min \end{array}$ & $\begin{array}{c}15 \\
\min \end{array}$ & $\begin{array}{c}20 \\
\min \end{array}$ \\
\hline $\begin{array}{l}\text { Mining, Quarrying, } \\
\text { And Oil And Gas } \\
\text { Extraction }\end{array}$ & $6 \%$ & $6 \%$ & $1 \%$ & $0 \%$ & $0 \%$ & $0 \%$ & $0 \%$ & $0 \%$ & $0 \%$ & $0 \%$ & $0 \%$ & $0 \%$ & $0 \%$ & $0 \%$ & $0 \%$ & $0 \%$ & $0 \%$ & $0 \%$ \\
\hline $\begin{array}{l}\text { Other Services } \\
\text { (Except Publuc } \\
\text { Administration) }\end{array}$ & $5 \%$ & $5 \%$ & $5 \%$ & $5 \%$ & $5 \%$ & $4 \%$ & $5 \%$ & $5 \%$ & $4 \%$ & $4 \%$ & $5 \%$ & $5 \%$ & $4 \%$ & $4 \%$ & $5 \%$ & $5 \%$ & $5 \%$ & $5 \%$ \\
\hline $\begin{array}{l}\text { Professional, } \\
\text { Scientific And } \\
\text { Technical Services }\end{array}$ & $12 \%$ & $11 \%$ & $12 \%$ & $12 \%$ & $8 \%$ & $9 \%$ & $11 \%$ & $11 \%$ & $9 \%$ & $9 \%$ & $14 \%$ & $12 \%$ & $9 \%$ & $9 \%$ & $12 \%$ & $11 \%$ & $13 \%$ & $12 \%$ \\
\hline $\begin{array}{l}\text { Public } \\
\text { Administration }\end{array}$ & $4 \%$ & $4 \%$ & $4 \%$ & $4 \%$ & $25 \%$ & $26 \%$ & $5 \%$ & $5 \%$ & $5 \%$ & $4 \%$ & $5 \%$ & $5 \%$ & $5 \%$ & $5 \%$ & $5 \%$ & $5 \%$ & $5 \%$ & $5 \%$ \\
\hline $\begin{array}{l}\text { Real Estate And } \\
\text { Rental And Leasing }\end{array}$ & $2 \%$ & $2 \%$ & $3 \%$ & $3 \%$ & $2 \%$ & $2 \%$ & $2 \%$ & $3 \%$ & $2 \%$ & $2 \%$ & $3 \%$ & $3 \%$ & $2 \%$ & $2 \%$ & $3 \%$ & $3 \%$ & $3 \%$ & $3 \%$ \\
\hline Retail Trade & $11 \%$ & $11 \%$ & $10 \%$ & $10 \%$ & $10 \%$ & $10 \%$ & $10 \%$ & $10 \%$ & $11 \%$ & $11 \%$ & $9 \%$ & $10 \%$ & $12 \%$ & $12 \%$ & $10 \%$ & $10 \%$ & $9 \%$ & $10 \%$ \\
\hline $\begin{array}{l}\text { Transportation And } \\
\text { Warehousing }\end{array}$ & $5 \%$ & $5 \%$ & $4 \%$ & $4 \%$ & $3 \%$ & $3 \%$ & $5 \%$ & $5 \%$ & $7 \%$ & $7 \%$ & $3 \%$ & $4 \%$ & $7 \%$ & $7 \%$ & $4 \%$ & $4 \%$ & $3 \%$ & $4 \%$ \\
\hline Utilities & $1 \%$ & $1 \%$ & $1 \%$ & $1 \%$ & $0 \%$ & $0 \%$ & $1 \%$ & $1 \%$ & $1 \%$ & $1 \%$ & $1 \%$ & $1 \%$ & $1 \%$ & $1 \%$ & $1 \%$ & $1 \%$ & $1 \%$ & $1 \%$ \\
\hline Wholesale Trade & $4 \%$ & $4 \%$ & $4 \%$ & $4 \%$ & $2 \%$ & $2 \%$ & $5 \%$ & $5 \%$ & $7 \%$ & $6 \%$ & $4 \%$ & $4 \%$ & $8 \%$ & $7 \%$ & $4 \%$ & $5 \%$ & $4 \%$ & $4 \%$ \\
\hline
\end{tabular}


Table A12: Relative trade area data for occupation variables

\begin{tabular}{|c|c|c|c|c|c|c|c|c|c|c|c|c|c|c|c|c|c|c|}
\hline \multirow[b]{2}{*}{$\begin{array}{c}\text { Variable } \\
\text { Description }\end{array}$} & \multicolumn{2}{|c|}{$\begin{array}{l}\text { Chinook } \\
\text { Centre }\end{array}$} & \multicolumn{2}{|c|}{$\begin{array}{l}\text { Downtown } \\
\text { Vancouver }\end{array}$} & \multicolumn{2}{|c|}{$\begin{array}{l}\text { Rideau } \\
\text { Centre }\end{array}$} & \multicolumn{2}{|c|}{$\begin{array}{l}\text { Sherway } \\
\text { Gardens }\end{array}$} & \multicolumn{2}{|c|}{ Square One } & \multicolumn{2}{|c|}{$\begin{array}{l}\text { Toronto } \\
\text { Eaton } \\
\text { Centre }\end{array}$} & \multicolumn{2}{|c|}{$\begin{array}{l}\text { Toronto } \\
\text { Premium } \\
\text { Outlet }\end{array}$} & \multicolumn{2}{|c|}{$\begin{array}{l}\text { Yorkdale } \\
\text { Shopping } \\
\text { Centre }\end{array}$} & \multicolumn{2}{|c|}{ Yorkville } \\
\hline & $\begin{array}{c}15 \\
\min \\
\end{array}$ & $\begin{array}{l}20 \\
\min \end{array}$ & $\begin{array}{c}15 \\
\min \\
\end{array}$ & $\begin{array}{c}20 \\
\min \\
\end{array}$ & $\begin{array}{c}15 \\
\min \\
\end{array}$ & $\begin{array}{c}20 \\
\min \\
\end{array}$ & $\begin{array}{c}15 \\
\min \end{array}$ & $\begin{array}{c}20 \\
\min \\
\end{array}$ & $\begin{array}{c}15 \\
\min \\
\end{array}$ & $\begin{array}{c}20 \\
\min \\
\end{array}$ & $\begin{array}{c}15 \\
\min \\
\end{array}$ & $\begin{array}{l}20 \\
\min \end{array}$ & $\begin{array}{c}15 \\
\min \\
\end{array}$ & $\begin{array}{c}20 \\
\min \\
\end{array}$ & $\begin{array}{c}15 \\
\min \\
\end{array}$ & $\begin{array}{l}20 \\
\min \end{array}$ & $\begin{array}{c}15 \\
\min \\
\end{array}$ & $\begin{array}{c}20 \\
\min \end{array}$ \\
\hline $\begin{array}{l}\text { Occupations In Art, } \\
\text { Culture, } \\
\text { Recreation, Sport }\end{array}$ & $3 \%$ & $3 \%$ & $7 \%$ & $6 \%$ & $4 \%$ & $4 \%$ & $5 \%$ & $5 \%$ & $2 \%$ & $3 \%$ & $6 \%$ & $5 \%$ & $2 \%$ & $2 \%$ & $5 \%$ & $4 \%$ & $6 \%$ & $5 \%$ \\
\hline $\begin{array}{l}\text { Business Finance } \\
\text { Administration }\end{array}$ & $18 \%$ & $18 \%$ & $18 \%$ & $19 \%$ & $19 \%$ & $20 \%$ & $18 \%$ & $18 \%$ & $19 \%$ & $18 \%$ & $18 \%$ & $18 \%$ & $19 \%$ & $19 \%$ & $18 \%$ & $18 \%$ & $18 \%$ & $18 \%$ \\
\hline $\begin{array}{l}\text { Occupations In } \\
\text { Health }\end{array}$ & $6 \%$ & $6 \%$ & $7 \%$ & $7 \%$ & $8 \%$ & $8 \%$ & $5 \%$ & $5 \%$ & $5 \%$ & $5 \%$ & $6 \%$ & $6 \%$ & $5 \%$ & $5 \%$ & $6 \%$ & $5 \%$ & $6 \%$ & $6 \%$ \\
\hline $\begin{array}{l}\text { Occupations } \\
\text { Unique To } \\
\text { Manufacture And } \\
\text { Utilities }\end{array}$ & $2 \%$ & $2 \%$ & $3 \%$ & $3 \%$ & $1 \%$ & $1 \%$ & $4 \%$ & $4 \%$ & $5 \%$ & $6 \%$ & $2 \%$ & $4 \%$ & $5 \%$ & $6 \%$ & $4 \%$ & $5 \%$ & $3 \%$ & $4 \%$ \\
\hline Management & $12 \%$ & $13 \%$ & $9 \%$ & $9 \%$ & $9 \%$ & $10 \%$ & $11 \%$ & $12 \%$ & $11 \%$ & $11 \%$ & $12 \%$ & $11 \%$ & $12 \%$ & $11 \%$ & $11 \%$ & $11 \%$ & $12 \%$ & $11 \%$ \\
\hline $\begin{array}{l}\text { Occupations } \\
\text { Unique To Primary } \\
\text { Industries }\end{array}$ & $2 \%$ & $2 \%$ & $1 \%$ & $1 \%$ & $0 \%$ & $1 \%$ & $1 \%$ & $1 \%$ & $1 \%$ & $1 \%$ & $0 \%$ & $1 \%$ & $1 \%$ & $1 \%$ & $1 \%$ & $1 \%$ & $0 \%$ & $1 \%$ \\
\hline $\begin{array}{l}\text { Occupations In } \\
\text { Sales And Service }\end{array}$ & $22 \%$ & $23 \%$ & $25 \%$ & $25 \%$ & $22 \%$ & $21 \%$ & $25 \%$ & $24 \%$ & $25 \%$ & $25 \%$ & $24 \%$ & $25 \%$ & $24 \%$ & $25 \%$ & $24 \%$ & $25 \%$ & $24 \%$ & $25 \%$ \\
\hline $\begin{array}{l}\text { Occupations In } \\
\text { Sciences }\end{array}$ & $10 \%$ & $10 \%$ & $9 \%$ & $9 \%$ & $12 \%$ & $13 \%$ & $9 \%$ & $9 \%$ & $10 \%$ & $9 \%$ & $9 \%$ & $9 \%$ & $11 \%$ & $10 \%$ & $10 \%$ & $10 \%$ & $9 \%$ & $9 \%$ \\
\hline $\begin{array}{l}\text { Occupations In } \\
\text { Social Science, } \\
\text { Education, } \\
\text { Government, } \\
\text { Religion }\end{array}$ & $11 \%$ & $11 \%$ & $13 \%$ & $13 \%$ & $17 \%$ & $16 \%$ & $12 \%$ & $13 \%$ & $10 \%$ & $11 \%$ & $15 \%$ & $14 \%$ & $10 \%$ & $10 \%$ & $14 \%$ & $13 \%$ & $15 \%$ & $14 \%$ \\
\hline $\begin{array}{l}\text { Occupations In } \\
\text { Trades, Transport, } \\
\text { Operators }\end{array}$ & $14 \%$ & $14 \%$ & $8 \%$ & $9 \%$ & $7 \%$ & $7 \%$ & $10 \%$ & $9 \%$ & $11 \%$ & $12 \%$ & $7 \%$ & $8 \%$ & $11 \%$ & $12 \%$ & $8 \%$ & $9 \%$ & $7 \%$ & $8 \%$ \\
\hline
\end{tabular}


Table A13: Relative trade area data for visible minority variables.

\begin{tabular}{|c|c|c|c|c|c|c|c|c|c|c|c|c|c|c|c|c|c|c|}
\hline \multirow[b]{2}{*}{ Variable Description } & \multicolumn{2}{|c|}{$\begin{array}{l}\text { Chinook } \\
\text { Centre }\end{array}$} & \multicolumn{2}{|c|}{$\begin{array}{l}\text { Downtown } \\
\text { Vancouver }\end{array}$} & \multicolumn{2}{|c|}{$\begin{array}{l}\text { Rideau } \\
\text { Centre }\end{array}$} & \multicolumn{2}{|c|}{$\begin{array}{l}\text { Sherway } \\
\text { Gardens }\end{array}$} & \multicolumn{2}{|c|}{ Square One } & \multicolumn{2}{|c|}{$\begin{array}{c}\text { Toronto } \\
\text { Eaton } \\
\text { Centre }\end{array}$} & \multicolumn{2}{|c|}{$\begin{array}{c}\text { Toronto } \\
\text { Premium } \\
\text { Outlet }\end{array}$} & \multicolumn{2}{|c|}{$\begin{array}{c}\text { Yorkdale } \\
\text { Shopping } \\
\text { Centre }\end{array}$} & \multicolumn{2}{|c|}{ Yorkville } \\
\hline & $\begin{array}{c}15 \\
\min \\
\end{array}$ & $\begin{array}{c}20 \\
\min \\
\end{array}$ & $\begin{array}{c}15 \\
\min \\
\end{array}$ & $\begin{array}{c}20 \\
\min \\
\end{array}$ & $\begin{array}{c}15 \\
\min \\
\end{array}$ & $\begin{array}{c}20 \\
\min \\
\end{array}$ & $\begin{array}{c}15 \\
\min \\
\end{array}$ & $\begin{array}{c}20 \\
\min \\
\end{array}$ & $\begin{array}{c}15 \\
\min \\
\end{array}$ & $\begin{array}{c}20 \\
\min \\
\end{array}$ & $\begin{array}{c}15 \\
\min \\
\end{array}$ & $\begin{array}{c}20 \\
\min \\
\end{array}$ & $\begin{array}{c}15 \\
\min \\
\end{array}$ & $\begin{array}{c}20 \\
\min \\
\end{array}$ & $\begin{array}{c}15 \\
\min \\
\end{array}$ & $\begin{array}{c}20 \\
\min \\
\end{array}$ & $\begin{array}{c}15 \\
\min \\
\end{array}$ & $\begin{array}{c}20 \\
\min \\
\end{array}$ \\
\hline Arab & $7 \%$ & $6 \%$ & $1 \%$ & $1 \%$ & $20 \%$ & $18 \%$ & $4 \%$ & $4 \%$ & $6 \%$ & $4 \%$ & $3 \%$ & $3 \%$ & $6 \%$ & $5 \%$ & $3 \%$ & $3 \%$ & $3 \%$ & $3 \%$ \\
\hline Black & $13 \%$ & $11 \%$ & $2 \%$ & $2 \%$ & $30 \%$ & $28 \%$ & $19 \%$ & $17 \%$ & $14 \%$ & $19 \%$ & $17 \%$ & $16 \%$ & $14 \%$ & $16 \%$ & $16 \%$ & $14 \%$ & $17 \%$ & $16 \%$ \\
\hline Chinese & $20 \%$ & $20 \%$ & $50 \%$ & $50 \%$ & $13 \%$ & $15 \%$ & $13 \%$ & $13 \%$ & $10 \%$ & $8 \%$ & $21 \%$ & $23 \%$ & $10 \%$ & $8 \%$ & $22 \%$ & $23 \%$ & $21 \%$ & $24 \%$ \\
\hline Filipino & $16 \%$ & $15 \%$ & $11 \%$ & $11 \%$ & $4 \%$ & $4 \%$ & $8 \%$ & $9 \%$ & $9 \%$ & $8 \%$ & $11 \%$ & $10 \%$ & $8 \%$ & $8 \%$ & $9 \%$ & $9 \%$ & $11 \%$ & $10 \%$ \\
\hline Japanese & $2 \%$ & $1 \%$ & $3 \%$ & $3 \%$ & $1 \%$ & $1 \%$ & $1 \%$ & $1 \%$ & $1 \%$ & $1 \%$ & $1 \%$ & $1 \%$ & $0 \%$ & $0 \%$ & $1 \%$ & $1 \%$ & $1 \%$ & $1 \%$ \\
\hline Korean & $3 \%$ & $3 \%$ & $4 \%$ & $4 \%$ & $1 \%$ & $1 \%$ & $2 \%$ & $3 \%$ & $2 \%$ & $1 \%$ & $4 \%$ & $4 \%$ & $1 \%$ & $1 \%$ & $4 \%$ & $3 \%$ & $4 \%$ & $3 \%$ \\
\hline Latin American & $8 \%$ & $7 \%$ & $3 \%$ & $3 \%$ & $7 \%$ & $6 \%$ & $8 \%$ & $7 \%$ & $5 \%$ & $6 \%$ & $7 \%$ & $6 \%$ & $4 \%$ & $5 \%$ & $7 \%$ & $5 \%$ & $7 \%$ & $6 \%$ \\
\hline South Asian & $18 \%$ & $24 \%$ & $12 \%$ & $13 \%$ & $11 \%$ & $13 \%$ & $29 \%$ & $33 \%$ & $43 \%$ & $41 \%$ & $20 \%$ & $22 \%$ & $48 \%$ & $46 \%$ & $22 \%$ & $28 \%$ & $20 \%$ & $23 \%$ \\
\hline Southeast Asian & $7 \%$ & $6 \%$ & $5 \%$ & $4 \%$ & $6 \%$ & $6 \%$ & $6 \%$ & $5 \%$ & $4 \%$ & $4 \%$ & $4 \%$ & $4 \%$ & $3 \%$ & $3 \%$ & $4 \%$ & $4 \%$ & $4 \%$ & $4 \%$ \\
\hline West Asian & $3 \%$ & $3 \%$ & $5 \%$ & $5 \%$ & $4 \%$ & $4 \%$ & $2 \%$ & $3 \%$ & $2 \%$ & $2 \%$ & $5 \%$ & $5 \%$ & $1 \%$ & $2 \%$ & $5 \%$ & $5 \%$ & $5 \%$ & $5 \%$ \\
\hline Not A Visible Minority & $73 \%$ & $68 \%$ & $48 \%$ & $48 \%$ & $78 \%$ & $77 \%$ & $55 \%$ & $54 \%$ & $49 \%$ & $49 \%$ & $61 \%$ & $54 \%$ & $42 \%$ & $47 \%$ & $53 \%$ & $49 \%$ & $60 \%$ & $53 \%$ \\
\hline
\end{tabular}


Table A14: Relative trade area data for household spending variables.

\begin{tabular}{|c|c|c|c|c|c|c|c|c|c|c|c|c|c|c|c|c|c|c|}
\hline \multirow[b]{2}{*}{ Variable Description } & \multicolumn{2}{|c|}{$\begin{array}{c}\text { Chinook } \\
\text { Centre }\end{array}$} & \multicolumn{2}{|c|}{$\begin{array}{l}\text { Downtown } \\
\text { Vancouver }\end{array}$} & \multicolumn{2}{|c|}{$\begin{array}{l}\text { Rideau } \\
\text { Centre }\end{array}$} & \multicolumn{2}{|c|}{$\begin{array}{l}\text { Sherway } \\
\text { Gardens }\end{array}$} & \multicolumn{2}{|c|}{ Square One } & \multicolumn{2}{|c|}{$\begin{array}{c}\text { Toronto } \\
\text { Eaton } \\
\text { Centre }\end{array}$} & \multicolumn{2}{|c|}{$\begin{array}{c}\text { Toronto } \\
\text { Premium } \\
\text { Outlet }\end{array}$} & \multicolumn{2}{|c|}{$\begin{array}{c}\text { Yorkdale } \\
\text { Shopping } \\
\text { Centre }\end{array}$} & \multicolumn{2}{|c|}{ Yorkville } \\
\hline & $\begin{array}{c}15 \\
\min \end{array}$ & $\begin{array}{c}20 \\
\min \end{array}$ & $\begin{array}{c}15 \\
\min \end{array}$ & $\begin{array}{c}20 \\
\min \end{array}$ & $\begin{array}{c}15 \\
\min \end{array}$ & $\begin{array}{c}20 \\
\min \end{array}$ & $\begin{array}{c}15 \\
\min \end{array}$ & $\begin{array}{c}20 \\
\min \end{array}$ & $\begin{array}{c}15 \\
\min \end{array}$ & $\begin{array}{l}20 \\
\min \end{array}$ & $\begin{array}{c}15 \\
\min \end{array}$ & $\begin{array}{c}20 \\
\min \end{array}$ & $\begin{array}{c}15 \\
\min \end{array}$ & $\begin{array}{c}20 \\
\min \end{array}$ & $\begin{array}{c}15 \\
\min \end{array}$ & $\begin{array}{c}20 \\
\min \end{array}$ & $\begin{array}{c}15 \\
\min \end{array}$ & $\begin{array}{c}20 \\
\min \end{array}$ \\
\hline Clothing & $6 \%$ & $6 \%$ & $5 \%$ & $5 \%$ & $5 \%$ & $5 \%$ & $5 \%$ & $5 \%$ & $5 \%$ & $5 \%$ & $5 \%$ & $5 \%$ & $5 \%$ & $5 \%$ & $5 \%$ & $5 \%$ & $5 \%$ & $5 \%$ \\
\hline Food & $15 \%$ & $15 \%$ & $16 \%$ & $16 \%$ & $15 \%$ & $14 \%$ & $15 \%$ & $15 \%$ & $15 \%$ & $15 \%$ & $15 \%$ & $15 \%$ & $14 \%$ & $15 \%$ & $15 \%$ & $15 \%$ & $15 \%$ & $15 \%$ \\
\hline Household operation & $6 \%$ & $6 \%$ & $6 \%$ & $6 \%$ & $6 \%$ & $6 \%$ & $6 \%$ & $6 \%$ & $6 \%$ & $6 \%$ & $6 \%$ & $6 \%$ & $6 \%$ & $6 \%$ & $6 \%$ & $6 \%$ & $6 \%$ & $6 \%$ \\
\hline Health care & $5 \%$ & $5 \%$ & $5 \%$ & $5 \%$ & $6 \%$ & $5 \%$ & $5 \%$ & $5 \%$ & $5 \%$ & $5 \%$ & $5 \%$ & $5 \%$ & $5 \%$ & $5 \%$ & $5 \%$ & $5 \%$ & $5 \%$ & $5 \%$ \\
\hline Income tax & $27 \%$ & $26 \%$ & $22 \%$ & $21 \%$ & $24 \%$ & $24 \%$ & $24 \%$ & $26 \%$ & $22 \%$ & $22 \%$ & $29 \%$ & $26 \%$ & $21 \%$ & $22 \%$ & $27 \%$ & $25 \%$ & $28 \%$ & $26 \%$ \\
\hline Personal care & $2 \%$ & $2 \%$ & $2 \%$ & $2 \%$ & $3 \%$ & $3 \%$ & $3 \%$ & $3 \%$ & $3 \%$ & $3 \%$ & $3 \%$ & $3 \%$ & $3 \%$ & $3 \%$ & $3 \%$ & $3 \%$ & $3 \%$ & $3 \%$ \\
\hline Recreation & $7 \%$ & $7 \%$ & $7 \%$ & $7 \%$ & $7 \%$ & $7 \%$ & $6 \%$ & $6 \%$ & $6 \%$ & $6 \%$ & $6 \%$ & $6 \%$ & $6 \%$ & $6 \%$ & $6 \%$ & $6 \%$ & $6 \%$ & $6 \%$ \\
\hline Shelter & $25 \%$ & $25 \%$ & $29 \%$ & $29 \%$ & $27 \%$ & $27 \%$ & $30 \%$ & $29 \%$ & $29 \%$ & $29 \%$ & $30 \%$ & $29 \%$ & $29 \%$ & $28 \%$ & $29 \%$ & $29 \%$ & $30 \%$ & $29 \%$ \\
\hline Transportation & $17 \%$ & $18 \%$ & $14 \%$ & $14 \%$ & $17 \%$ & $17 \%$ & $15 \%$ & $16 \%$ & $17 \%$ & $17 \%$ & $14 \%$ & $15 \%$ & $18 \%$ & $18 \%$ & $15 \%$ & $16 \%$ & $15 \%$ & $15 \%$ \\
\hline
\end{tabular}




\section{References}

Alteryx (2016). Alteryx Software: Release 11.0. Irvine, CA

Azanlerigu, J. A., \& Atiga, O. (2015, December 25). Applicability of the Huff model in the estimation of market shares of supermarkets within the Tamale metropolis in Ghana. African Journal of Business Management, 9(23), 789-788.

Bermingham, P., Hernandez, T., \& Lea, A. (2004). What's in a Trade Area. CSCA.

Bozdo, R., Thanasi, M., \& Vjollca, H. (2013, May 21). Shopping Centers, Retail location, and Trade Area: The Case of Shopping Centers in Albania. Journal of Marketing and Management, 21-30.

Brunner, J. A., \& Mason, J. L. (1968). The influence of driving time upon shopping center preference. Journal of Marketing, 57-61.

Carpenter, J. M. (2006). Demographics and patronage motives of supercenter shoppers in the United States. International Journal of Retail \& Distribution Management, 5-16.

Cui, C. W. (2012). GIS-based method of delimitating trade area for retail chains. International Journal of Geographical Information Science, 1863-1879.

De Beule, M., Van den Poel, D., \& Van de Weghe, N. (2014). An extended Huff model for robustly benchmarking and predicting retail network performance. Applied Geography.

DMTI Spatial Inc. (2015). CanMap Content Suite. Markham, Ontario, Canada.

Dramowicz, E. (2005). Retail Trade Area Analysis Using the Huff Model. Directions Magazine.

Emmons, M., \& Hernandez, T. (2016). Foreign Retail Chains in Canada. Toronto: CSCA.

Environics. (2016). DemoStats [Datafile]. Toronto, CA

Environics. (2016). HouseholdSpend [Datafile]. Toronto, CA

Environmental Systems Research Institute (ESRI). (2011). ArcGIS Desktop Software: Release 10.0. Redlands, $C A$ 
Griffiths, W. (2016, July 6). Creating a Voronoi diagram in Alteryx. Retrieved from The Infomration Lab - Data School: http://www.thedataschool.co.uk/will-griffiths/creatingvoronoi-diagram-alteryx/

Huff, D. (2003). Parameter Estimation in Huff Model. ESRI.

Jones, K., \& Simmons, J. (1993). Location, Location, Location Analyzing the Retail Environment. Scarborough, Ontario, Canada: Nelson Canada.

Kodinariya, T. M., \& Makwana, P. R. (2013). Review on determining number of Cluster in KMeans Clustering. International Journal of Advance Research in Computer Science and Management Studies, 90-95.

Kuruvilla, S. J., \& Joshi, N. (2010). Influence of demographics, psychographics, shopping orientation, mall. Journal of Retailing and Consumer Services, 259-269.

Leventhal, B. (2016). Geodemographics for Marketers. Kogan Page.

Marjanen, H., Engblom, J., \& Malmari, M. (2013). Viability of demographic and behavioural independent variables in quantile regression models in predicting retail patronage. The International Review of Retail, 523-536.

Mishra, P., Sridhar, G., \& Jain , T. (2015). Shopper's attitude and demographics influence on store patronage - a comparison of formal vs. informal food retail stores in India. Indian Culture and Business Management, 203-218.

Okabe, A., et al. (2008). Generalized network Voronoi diagrams: concepts, computational methods,. International Journal of Geographical Information Science,, 965-994.

Retail Insider. (2016). Luxury Brands Increasingly Choosing Suburban Canadian Malls [Analysis]. Retrieved from http://www.retail-insider.com/retail-insider/2016/12/luxury

Statistics Canada. (2017). Canadian Income Survey. Retrieved from Statisitics Canada: http://www23.statcan.gc.ca/imdb/p3Var.pl?Function=DEC\&ld=45152 
Statistics Canada. (2015). Visible minority of person. Retrieved from Statisitics Canada:

http://www.statcan.gc.ca/daily-quotidien/170526/dq170526a-eng.htm

Statistics Canada. (2011a). Commuting to work. Retrieved July 15, 2017, from Statistics Canada: http://www12.statcan.gc.ca/nhs-enm/2011/as-sa/99-012-x/99-012-x2011003_1eng.cfm

Statistics Canada. (2011b). Immigration and Ethnocultural Diversity in Canada. Retrieved from Statisitics Canada: http://www12.statcan.gc.ca/nhs-enm/2011/as-sa/99-010-x/99-010x2011001-eng.cfm

Statistics Canada. (2011c). 2011 Census - Boundary files. Retrieved from Boundary files:

http://www12.statcan.gc.ca/census-recensement/2011/geo/bound-limit/bound-limit2011-eng.cfm

Statistics Canada. (2011d). Census metropolitan area (CMA) and census agglomeration (CA).

Retrieved from Reference Material: http://www12.statcan.gc.ca/censusrecensement/2011/ref/dict/geo009-eng.cfm

Statistics Canada. (2011e). Census tract (CT). Retrieved from Census Dictonary: http://www12.statcan.gc.ca/census-recensement/2011/ref/dict/geo013-eng.cfm

Swales, S. (2008). Marketing Geography. Pearson Custom Publishing. 